UNIVERSIDADE DE SÃO PAULO

FACULDADE DE FILOSOFIA LETRAS E CIÊNCIAS HUMANAS

DEPARTAMENTO DE LETRAS CLÁSSICAS E VERNÁCULAS

PROGRAMA DE PÓS-GRADUAÇÃO EM ESTUDOS COMPARADOS DE

LITERATURAS DE LÍNGUA PORTUGUESA

ECILA LIRA DE LIMA MABELINI

SOBRE LOBOS, MENINAS E FLORESTAS:

Literatura Infantil/Juvenil e Valores Sociais

VERSÃO CORRIGIDA

São Paulo

2019 


\author{
UNIVERSIDADE DE SÃO PAULO \\ FACULDADE DE FILOSOFIA LETRAS E CIÊNCIAS HUMANAS \\ DEPARTAMENTO DE LETRAS CLÁSSICAS E VERNÁCULAS \\ PROGRAMA DE PÓS-GRADUAÇÃO EM ESTUDOS COMPARADOS DE \\ LITERATURAS DE LÍNGUA PORTUGUESA
}

ECILA LIRA DE LIMA MABELINI

\title{
SOBRE LOBOS, MENINAS E FLORESTAS: \\ Literatura Infantil/Juvenil e Valores Sociais
}

Tese apresentada à Faculdade de Filosofia, Letras e Ciências Humanas da Universidade de São Paulo para obtenção do título de Doutora em Letras.

Área de concentração: Estudos Comparados de Literaturas de Língua Portuguesa.

Orientador: Prof. Dr. José Nicolau Gregorin Filho.

\section{VERSÃO CORRIGIDA}


Autorizo a reprodução e divulgação total ou parcial deste trabalho, por qualquer meio convencional ou eletrônico, para fins de estudo e pesquisa, desde que citada a fonte.

Catalogação na Publicação

Serviço de Biblioteca e Documentação

Faculdade de Filosofia, Letras e Ciências Humanas da Universidade de São Paulo

Mabelini, Ecila Lira de Lima

Sobre Lobos, Meninas e Florestas: Literatura

Infantil/Juvenil e Valores Sociais / Ecila Lira de

Lima Mabelini ; orientador José Nicolau Gregorin

Filho. - São Paulo, 2019.

$172 \mathrm{f}$.

Tese (Doutorado)- Faculdade de Filosofia, Letras e Ciências Humanas da Universidade de São Paulo. Departamento de Letras Clássicas e Vernáculas. Área de concentração: Estudos Comparados de Literaturas de Língua Portuguesa.

1. Literatura Infantil. 2. Literatura Juvenil. 3. Imaginário. 4. Leitor. 5. Livro. I. Gregorin Filho, José Nicolau, orient. II. Título. 


\section{ENTREGA DO EXEMPLAR CORRIGIDO DA DISSERTAÇÃO/TESE}

Termo de Ciência e Concordância do (a) orientador (a)

Nome do (a) aluno (a): Ecila Lira de Lima Mabelini

Data da defesa: 25/06/2019

Nome do Prof. (a) orientador (a): Dr. José Nicolau Gregorin Filho

Nos termos da legislação vigente, declaro ESTAR CIENTE do conteúdo deste EXEMPLAR CORRIGIDO elaborado em atenção às sugestões dos membros da comissão Julgadora na sessão de defesa do trabalho, manifestando-me plenamente favorável ao seu encaminhamento e publicação no Portal Diqital de Teses da USP.

São Paulo, 26/08/2019

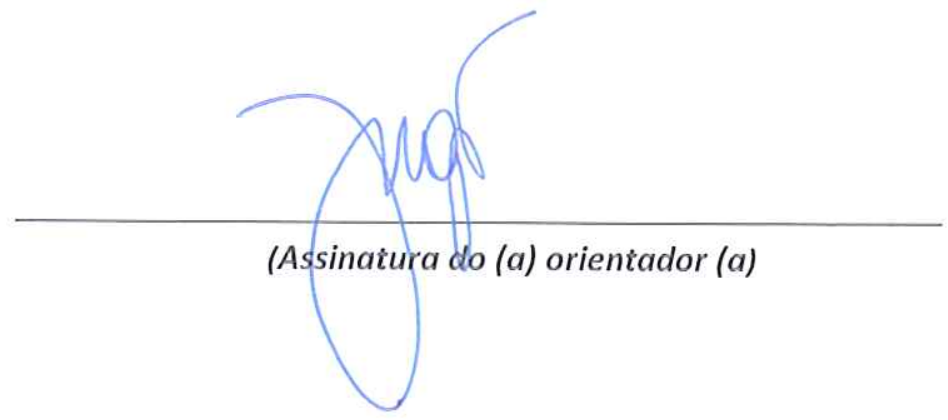


MABELINI, Ecila Lira de Lima

SOBRE LOBOS, MENINAS E FLORESTAS: Literatura Infantil/Juvenil e Valores Sociais

Tese apresentada à Faculdade de Filosofia, Letras e Ciências Humanas da Universidade de São Paulo para obtenção do título de Doutora em Letras.

Aprovada em:

Banca Examinadora

Prof. Dr.

Instituição:

Julgamento:

Prof. Dr.

Instituição:

Julgamento:

Prof. Dr.

Instituição:

Julgamento:

Prof. Dr.

Instituição:

Julgamento: 
Dedico aos filhos, Yago e Ycaro.

"Sem salto eu salto alto $\mathrm{O}$ salto que ressalta porque se atreve $\mathrm{O}$ salto que sente o salto mais leve O salto que está na verve O salto que não se serve O salto que se dá quando não se pede O salto que descompassa quando passa sem graça O salto que não se entrega por trapaça

Eu salto alto o legítimo salto Eu salto em todas as direções Eu salto na contramão Eu salto pelo que sinto e vejo Eu salto quando almejo Meu alto não está no baixo do sapato de salto Meu alto não está no facto do opressor Meu alto não depende do voo das asas do agressor

Meu salto desdiz ditosamente aquele que dita Meu salto me descalça para o que assalta e grita Meu salto tem vez, voz e replica!" (MABELINI, 2018, p. 781). 


\section{AGRADECIMENTOS}

À Fundação de Amparo à Pesquisa do Estado do Amazonas, pela concessão da bolsa de doutorado e pelo apoio financeiro para a realização desta pesquisa.

Ao Programa de Estudos Comparados de Literaturas de Língua Portuguesa, pela calorosa acolhida.

Ao Prof. Dr. José Nicolau Gregorin Filho, orientador querido, que nos anos de convivência muito me ensinou e contribuiu para meu desenvolvimento científico, intelectual e humano. À Profa. Dra. Maria Zilda da Cunha, pela atenção e apoio durante todo o percurso da pesquisa.

À Profa. Dra. Maria dos Prazeres Santos Mendes, pelo carinho e generosidade incontestes. Aos meus pais Josefa e Manoel, com gratidão, pela presença e auxílio incansáveis.

Aos meus irmãos Eraldo, Edgar e Éder, pelo apoio e afeto da torcida.

Ao meu esposo Orlando, pelo estímulo e companhia permanentes ao longo do período de elaboração deste trabalho.

À Nelise, cunhada estimada, pela assessoria sempre presente com as imagens utilizadas na pesquisa.

À amiga Edna, pela especial parceria na pesquisa e nas coisas do mundo do vivido.

A todos os amigos de pesquisa e de vida (mesmo nos desencontros), por tornarem mais leve a jornada. 
“(...) Cada época compreendeu e produziu literatura a seu modo. Conhecer esse "modo" é, sem dúvida, conhecer a singularidade de cada momento da longa marcha da humanidade, em sua constante evolução. Conhecer a literatura que cada época destinou às suas crianças é conhecer os ideais e valores ou desvalores sobre os quais cada sociedade se fundamentou (e se fundamenta...).” (COELHO, 2000, p. 27-28). 


\section{RESUMO}

MABELINI, Ecila Lira de. SOBRE LOBOS, MENINAS E FLORESTAS: Literatura Infantil/Juvenil e Valores Sociais. 2019. 172 f. Tese (Doutorado) - Faculdade de Filosofia, Letras e Ciências Humanas, Universidade de São Paulo, São Paulo, 2019.

Esta pesquisa tem como objetivo primeiro investigar as transformações nos textos literários para crianças e jovens, oriundos de mudanças nas relações sociais, e verificar em que medida a literatura infantil e mesmo a juvenil tem exteriorizado no seu universo textual novas maneiras de percepção sobre as narrativas primordiais ou clássicas, consolidadas como tal a partir do século XVII. Na contemporaneidade, sobretudo a partir da segunda metade do século XX no Brasil da releitura do novo texto infantil, observou-se que tais narrativas e seus valores outrora marcados pela presença de uma pedagogia altamente moralizante e excludente, agora reorganizam as estratégias de captação para retomar não só os clássicos ou histórias que caíram no gosto da criança e do jovem, no passado, mas ainda para atualizar narrativas capazes de fazer parecer serem outras, dado o novo arranjo da "vestimenta" destas novas histórias que intencionam, de modo significativo, evidenciar uma literatura com mais recursos de visualidade e plasticidade, bem como um modo de ser e de estar dessa nova criança e também do jovem num mundo de valores diversos, cujos reflexos corroboram um universo literário de atualizadas prescrições. Assim, tomou-se como corpora as obras Chapeuzinho Amarelo (2006), de Chico Buarque, ilustração de Ziraldo, Chapeuzinho Vermelho (1996), de Charles Perrault, Chapeuzinho Vermelho, dos Grimm (2009), Sapato de salto (2011), de Lygia Bojunga, Antecedentes de uma famosa história (2010), de Carolina Alonso, ilustração de Mariana Massarani, conto publicado em Não era uma vez: contos clássicos recontados - coletânea de autores latino-americanos, $A$ outra história de Chapeuzinho Vermelho (2016), de Jean-Claude R. Alphen, ilustrada pelo próprio autor e as intersecções forjadas no texto Preciosidade (1991), de Clarice Lispector, conto publicado em Laços de família. Para tal investigação, foram utilizados como fundamentação teórica elementos dos Estudos Comparados de Literatura, bem como de outras ciências da linguagem afins, além de estudos sobre a gênese e a História da Literatura Infantil e, posteriormente, a Juvenil. Com base em estudos já desenvolvidos sobre essa modalidade de textos, busca-se adentrar mais um pouco nessa floresta ainda vasta de textos que refletem valores humanos e sociais.

Palavras-chave: Literatura Infantil, Literatura Juvenil, Imaginário, Leitor, Livro. 


\begin{abstract}
MABELINI, Ecila Lira de. ABOUT WOLVES, GIRLS AND FORESTS: Child /Youth Literature and Social Values. 2019. 172 f. Tese (Doutorado) - Faculdade de Filosofia, Letras e Ciências Humanas, Universidade de São Paulo, São Paulo, 2019.

This research aims at investigating the transformations in literary texts for children and young people from social relations changes and at verifing the extent to which children's and still youth literature has externalized in their textual universe new ways of perception about primordial or classical narratives, consolidated as such from the seventeenth century. In contemporary times, the re-reading of the new children's text, especially since the second half of the twentieth century in Brazil, was observed that such narratives and their values were once marked by the presence of a highly moralizing and excluding pedagogy, now reorganize the capture strategies to resume not only the classics or stories that have fallen in the taste of the child and the youth in the past, but still to update narratives capable of making appear to be others, given the new arrangement of the "clothing" of these new stories that intend, in a significant way, a literature with more visuality features and plasticity, as well as a way of being of this new child and youth in a world of diverse values, whose reflections corroborate a literary universe of up-to-date prescriptions. Thus, it was taken as corpora the works Chapeuzinho Amarelo (2006), by Chico Buarque and illustrated by Ziraldo, Chapeuzinho Vermelho (1996), by Charles Perrault, Chapeuzinho Vermelho, by Grimm (2009), Sapato de salto (2011), by Lygia Bojunga, Antecedentes de uma famosa história (2010), by Carolina Alonso with illustration by Mariana Massarani, short story published in Não era uma vez: contos clássicos recontados - a collection of latin american authors, A outra história de Chapeuzinho Vermelho (2016), by Jean-Claude R. Alphen, illustrated by the author himself and the intersections forged in the text Preciosidade (1991), by Clarice Lispector, a tale published in Laços de Família. For this investigation, elements of Comparative Literature Studies, as well as other related language sciences and studies on the genesis and History of Children's and Juvenile Literature were used as theoretical basis. Based on studies already developed on this modality of texts, it aims at penetrating a little more in the still vast forest of texts that reflect human and social values.
\end{abstract}

Keywords: Children's Literature, Young's Literature, Imaginary, Reader, Book. 


\section{LISTA DE FIGURAS}

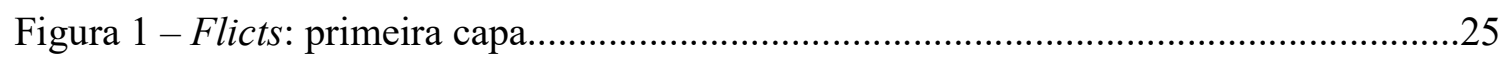

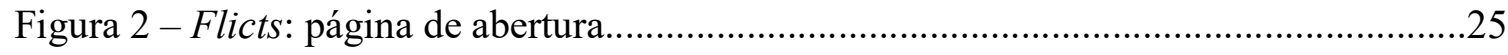

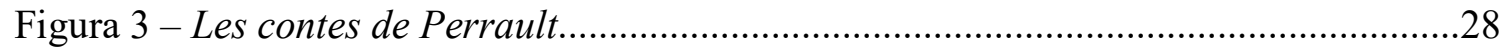

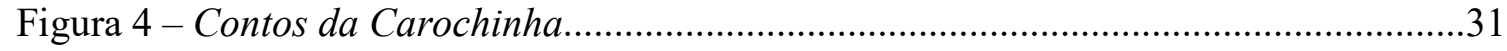

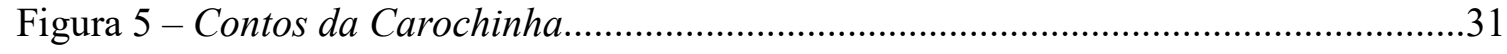

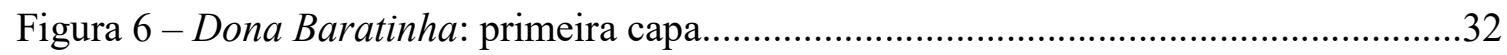

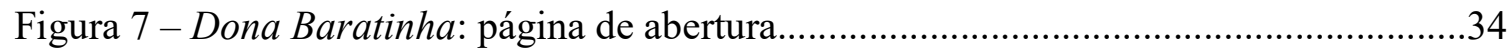

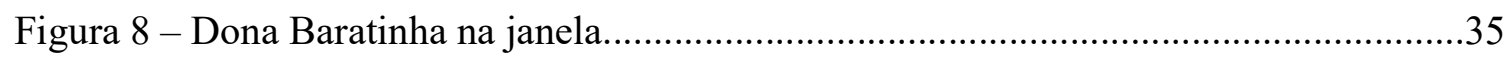

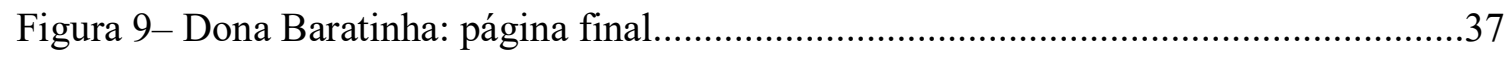

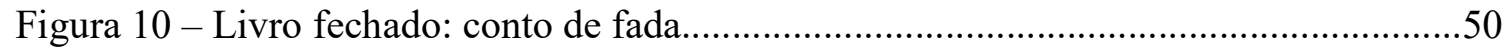

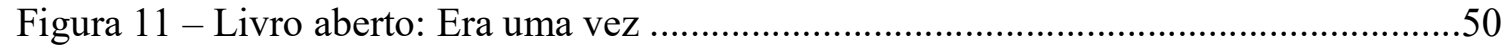

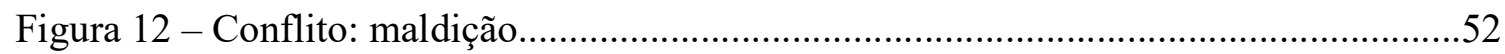

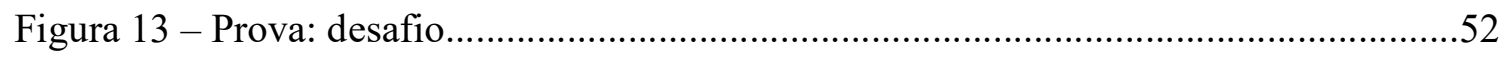

Figura 14 - Confirmação da competência..........................................................................52

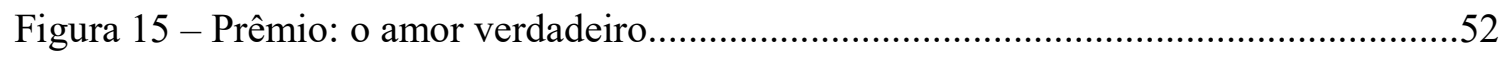

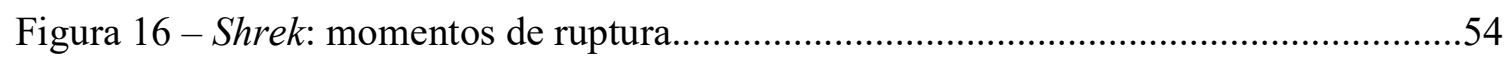

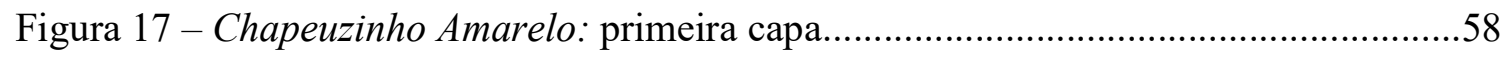

Figura 18 - Chapeuzinho Amarelo: primeira capa..........................................................61

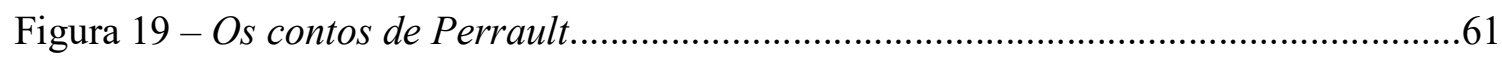

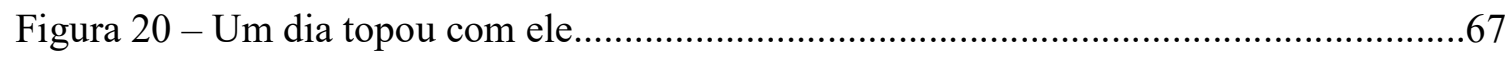

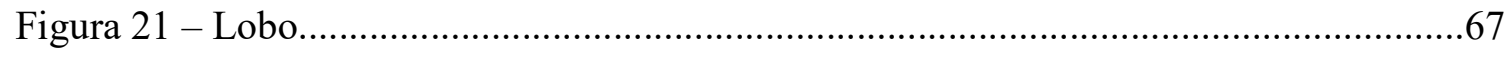

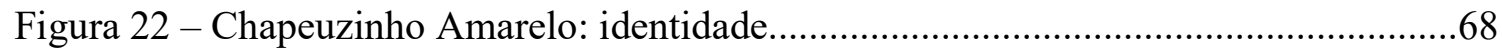

Figura 23 - Chapeuzinho Amarelo: quarta capa........................................................... 70

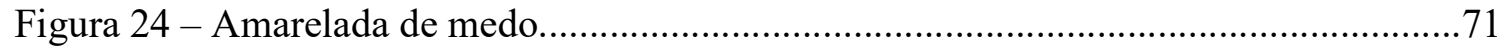

Figura 25 - Não comeu aquele bolo de lobo......................................................................

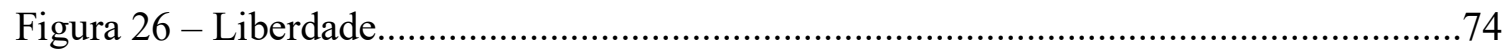

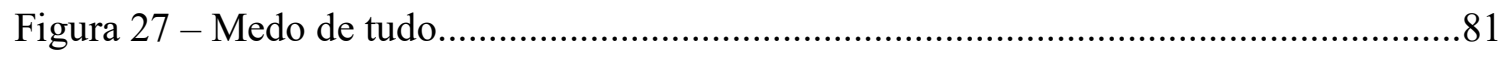

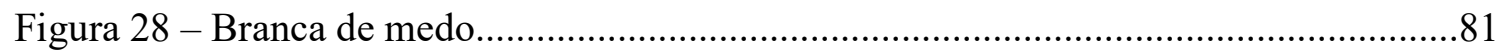




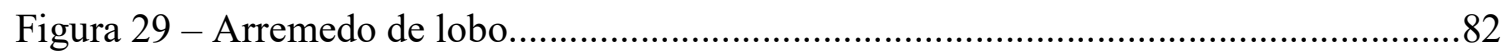

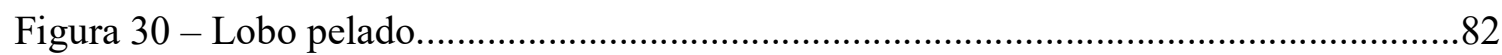

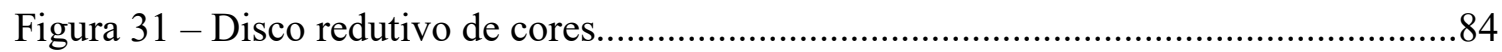

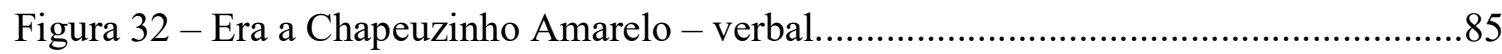

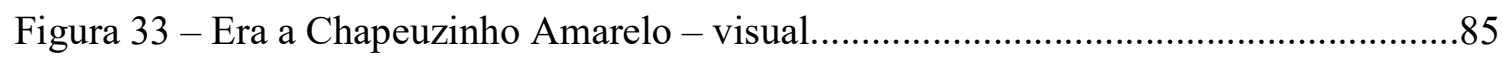

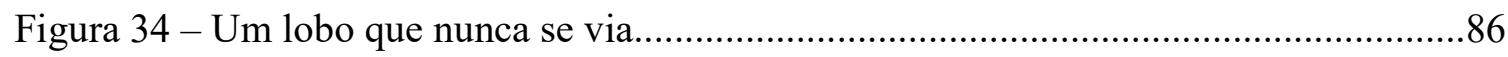

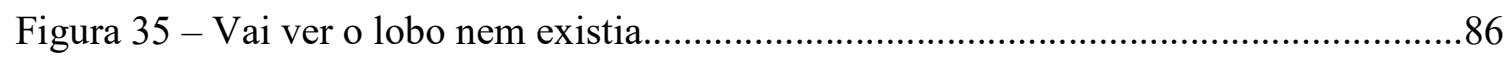

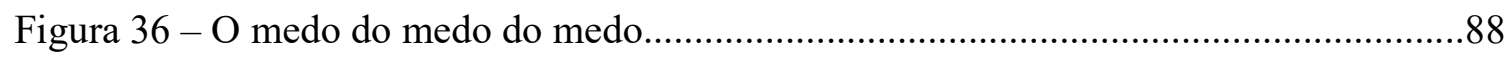

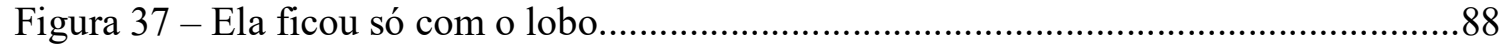

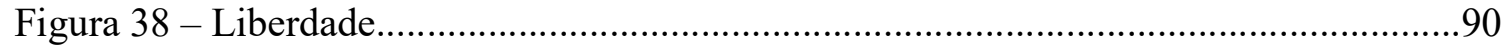

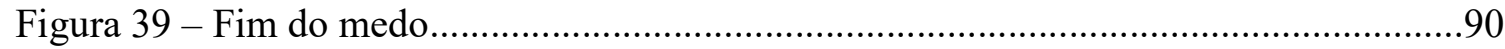

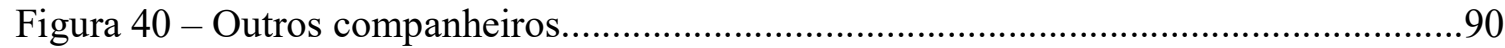

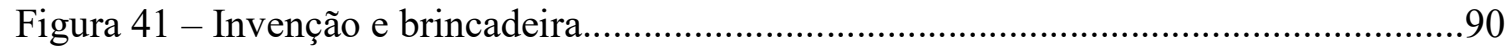

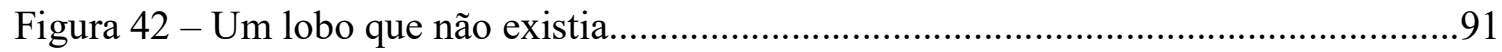

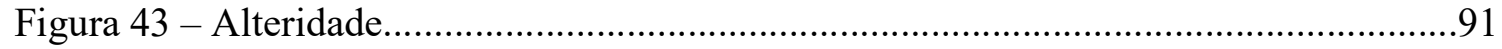

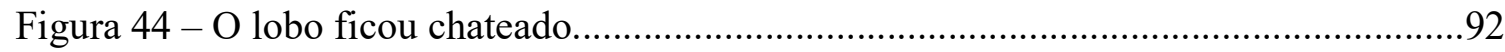

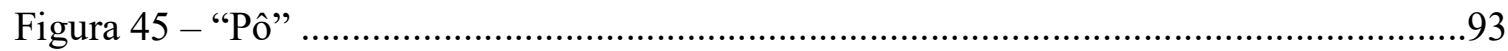

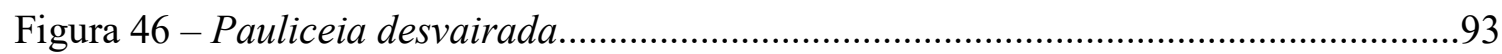

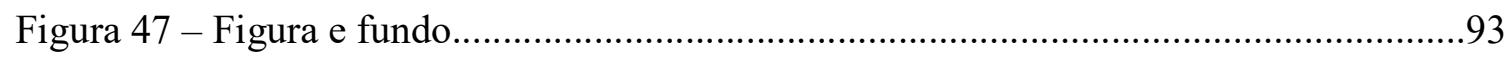

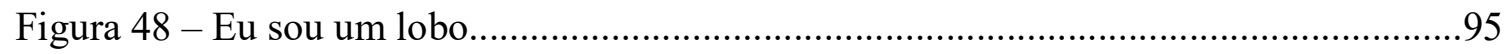

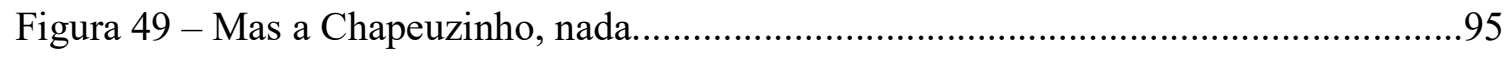

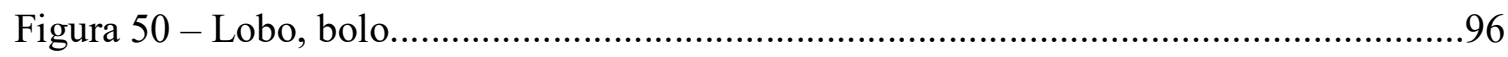

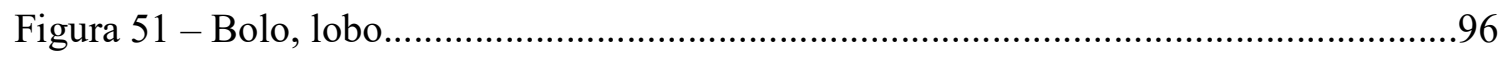

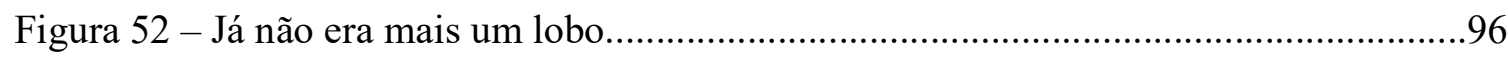

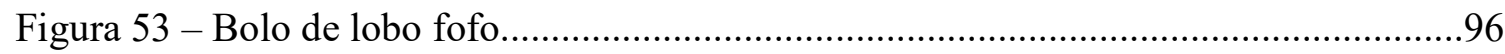

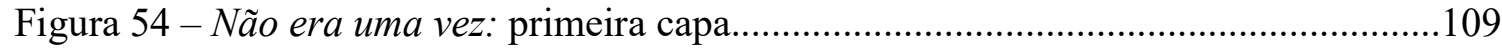

Figura 55 - Conto: Antecedentes de uma famosa história ...................................................109

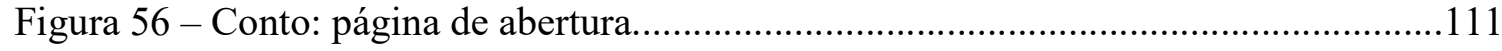

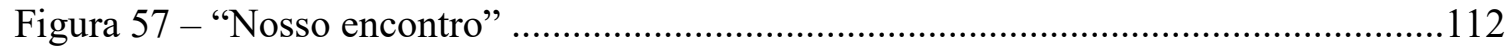

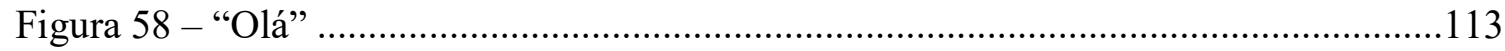

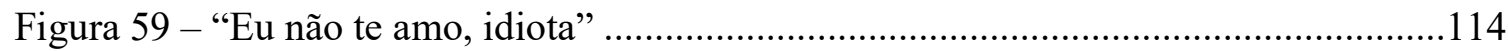




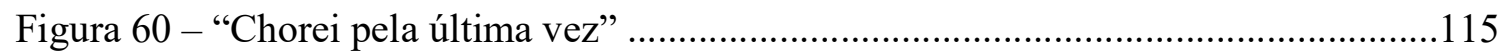

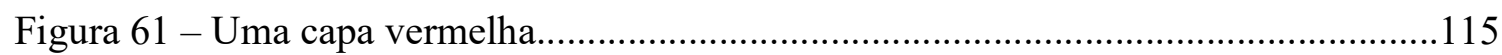

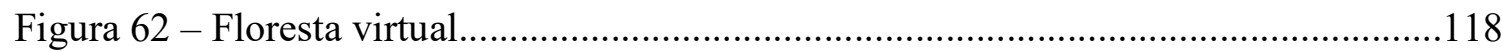

Figura 63 - A outra história de Chapeuzinho Vermelho: primeira capa............................119

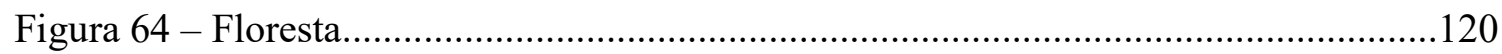

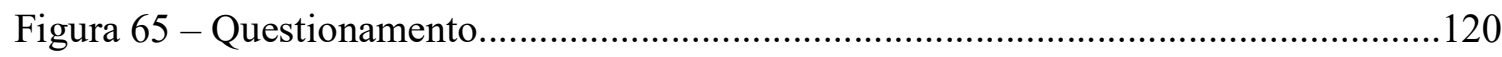

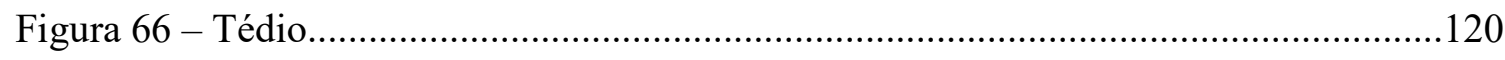

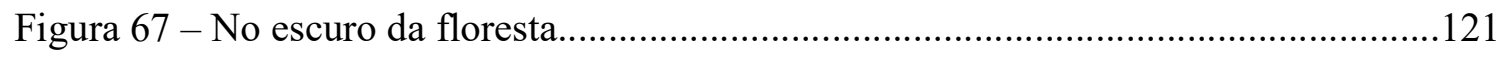

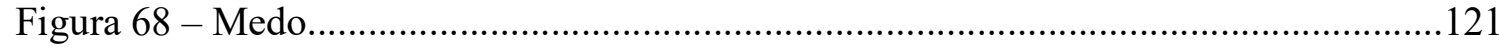

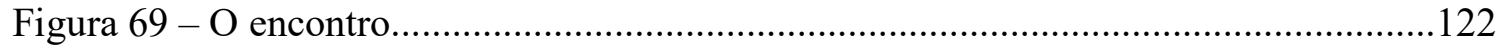

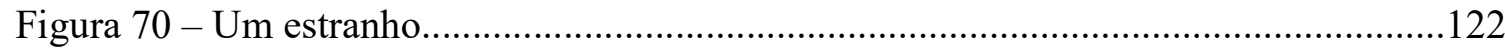

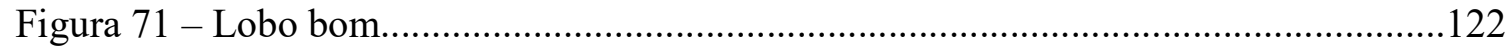

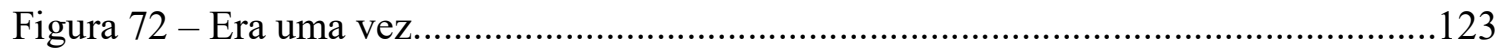

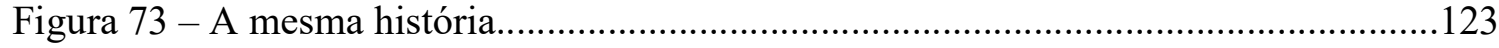

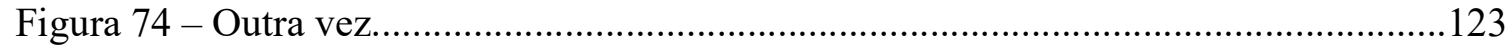

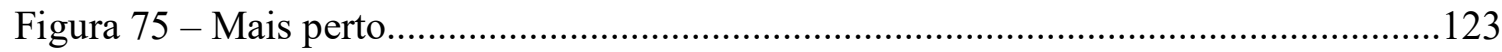

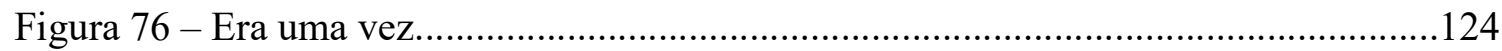

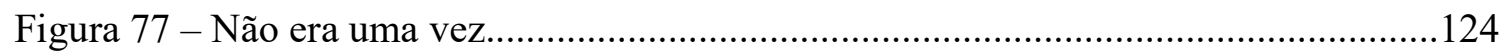

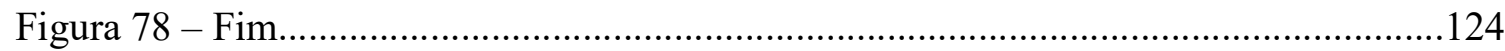

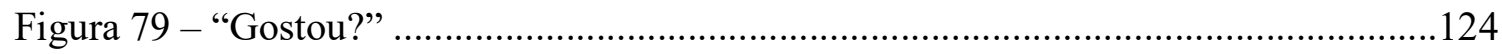

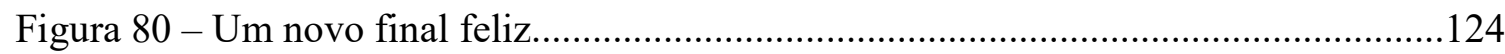

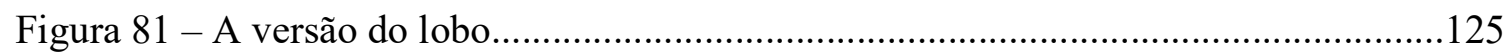

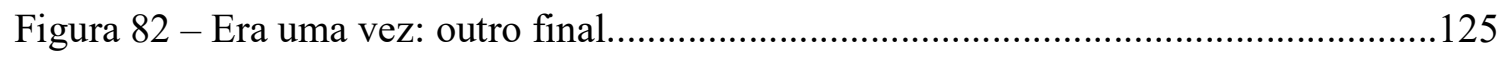

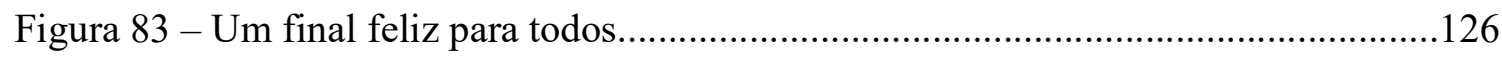

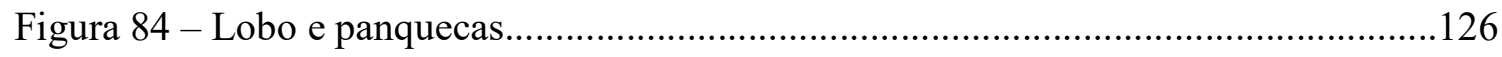

Figura 85 - A outra história de Chapeuzinho Vermelho: quarta capa................................127

Figura 86 - Os contos de Perrault: Chapeuzinho Vermelho.............................................131

Figura 87 - Contos de Grimm; Capuchinho Vermelho: primeira capa..............................133

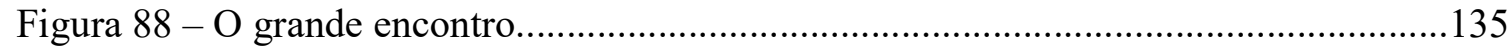

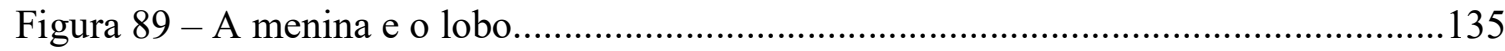

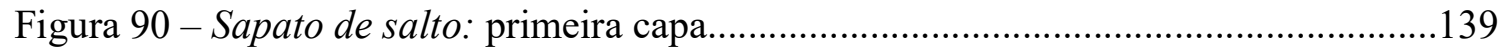


Figura 91 - Conto: Antecedentes de uma famosa história .....................................................141

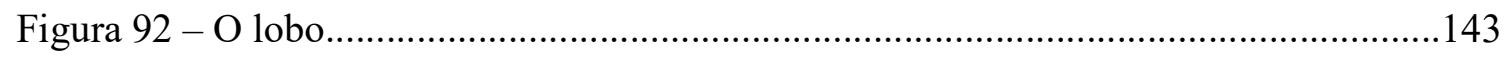

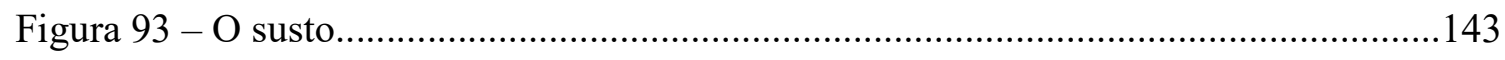

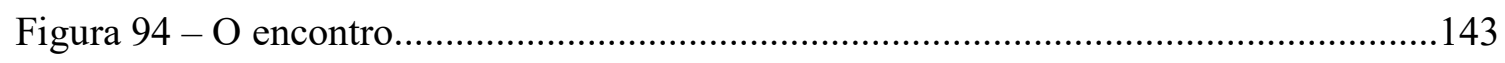

Figura 95 - Laços de família; conto Preciosidade: primeira capa....................................145 


\section{SUMÁRIO}

INTRODUÇÃ

I LITERATURA INFANTIL: TRANSFORMAÇÕES EM CURSO_..............................22

II TRADIÇÃO E REPRESENTAÇÃO NA LITERATURA INFANTIL.......................44

III REPRESENTAÇÃO SOCIAL PELA LITERATURA.............................................57

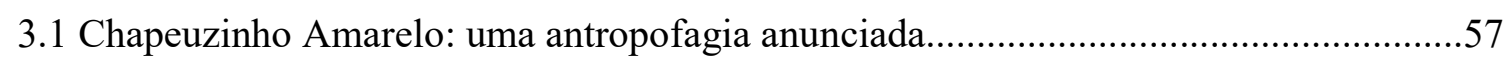

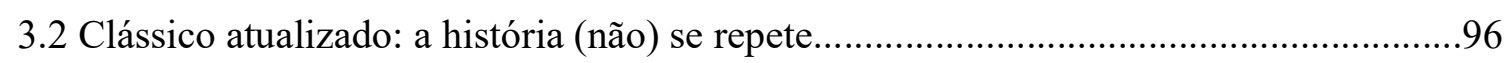

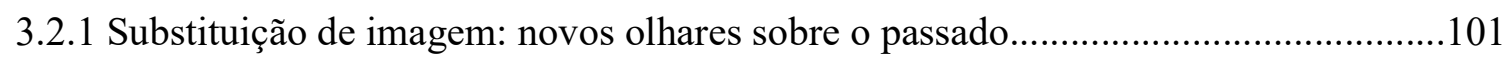

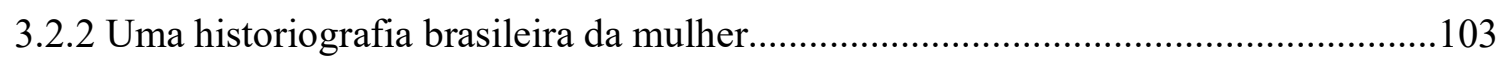

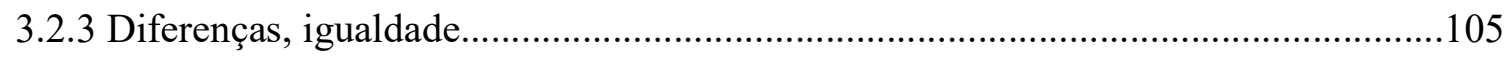

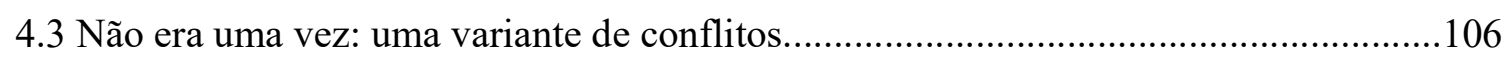

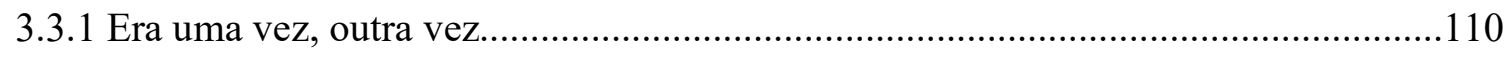

3.4 Fratura no tempo e no espaço: estereótipos em reconstrução.......................................118

3.5 Literatura infantil e juvenil: valores e desvalores..................................................... 127

3.5.1 Esquema de representação: lobos, meninas e florestas.............................................146

CONSIDERAÇÕES FINAIS: O LOBO COMEU? ............................................152

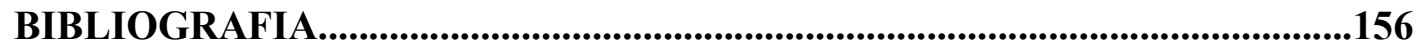

ANEXOS 


\title{
INTRODUÇÃO
}

\begin{abstract}
"O texto é sempre, sob modalidades várias, um intercâmbio discursivo, uma tessitura polifónica na qual confluem, se entrecruzam, se metamorfoseiam, se corroboram ou se contestam outros textos, outras vozes e outras consciências" (SILVA, 2011, p. 625).
\end{abstract}

Ao procurar entender um mundo organizado por meio das leituras pressupostas em um universo de muitas linguagens, o indivíduo experimenta-se não só como partícipe da língua, inerente ao próprio ser, mas também como sujeito de um universo plurissignificativo de valores. Nesse contexto de comunicação vital, observam-se lugares como indicadores que, desde os tempos primevos, deslocam o homem na constante busca da pertença. A partir da oralidade e posteriormente da escrita, esse homem tenta afirmar sua identidade $^{1}$ com o propósito de entender a si mesmo e o mundo no qual se insere para viver as percepções que o sondam.

Tal movimento de buscas e reconhecimentos acena para uma reflexão nada simples, sobretudo quando se pensa no texto literário e no seu fazer-se entender via linguagem. Afinal, a linguagem que tece as significações nos textos está implicada numa trama sob diferentes formas de articulação e organização de sentidos considerando, portanto, como Fiorin, que ela:

desafia os homens há milênios, porque dela se pode dizer o que dizia Riobaldo, no Grande sertão: veredas: "Todos estão loucos, neste mundo? Porque a cabeça da gente é uma só, e as coisas que há e que estão para haver são demais de muitas, muito maiores diferentes, e a gente tem de necessitar de aumentar a cabeça para o total.” (FIORIN, 1997, p. 78)

O desafio proposto pela linguagem envereda por caminhos complexos na tentativa de se entender, ao longo dos tempos, as diferentes expressões que organizam os textos, geradas tanto por meio dos símbolos quanto das formas que buscam significá-las, principalmente à medida que propõem uma maneira também diferente de percepção do todo que está implicado na produção de sentido dos textos e nos diferentes modos organizados no sentir dos sujeitos leitores.

\footnotetext{
${ }^{1}$ Identidade, portanto, como identificações em curso, de acordo com Boaventura de Souza Santos (2013, 187-194). Tal conceito será abordado mais adiante.
} 
Diante disso, observa-se como a necessidade social do indivíduo de se expressar e expressar as sensações vividas, o levou a interagir com as muitas formas de linguagens que se manifestaram e ainda continuam se manifestando de diferentes pontos de vista e em diferentes suportes textuais. Esse processo desencadeou o surgimento e o crescimento de múltiplas expressões, sobretudo no Brasil a partir do final do século XX, capazes de proporcionar a interação, o lúdico, a liberdade e o prazer estético de forma figurativa, reorganizando um outro modo de ser e de estar no mundo onde tempo, espaço e sujeito se modificaram diante do novo cenário da literatura infantil e suas diferentes projeções nos livros. Afinal:

[...] a verdadeira evolução de um povo se faz ao nível da mente, ao nível da consciência de mundo que cada um vai assimilando desde a infância. [...] E parece já fora de qualquer dúvida que nenhuma outra forma de ler o mundo dos homens é tão eficaz e rica quanto a que a literatura permite. (COELHO, 2000, p. 15).

Assim, importa observar o que o texto diz e como faz para dizer, considerando que no texto literário infantil, em especial, entendido como uma tipologia textual específica para crianças e jovens, a significação ao se compor faz crer a esses leitores a existência de um universo em que eles podem se ver e, ainda, se manifestar como enunciadores. Para isso, a linguagem (expressão verbal, escrita) - eleita pelo mundo ocidental como instrumento que concretiza a cidadania, veicula a cultura, a sensibilidade e o imaginário se une à linguagem (expressão não verbal, visual) na construção de valores atualizados e reorganizados, dados a ver como novos por uma unidade de sentido textual capaz de captar a atenção desses leitores, já inscritos no texto, no momento em que eles entram em contato com a leitura do livro.

Com efeito, na atualidade, dadas as mudanças estéticas que passam a fazer parte dos livros de literatura destinados à criança e ao jovem, considerar-se-á a relação verbal e visual como expressões que refletem modos de interação, quando organizadas num mesmo suporte (livro infantil e juvenil), observando-se os deslocamentos que estas linguagens realizam no texto literário. Além disso, é importante pontuar um novo status da linguagem visual que, diferente do modo como fora consagrada no passado, quando figurava como mera ilustração ou relação de copresença nas obras ditas literárias para crianças e jovens, 
agora, organiza junto com a linguagem verbal uma também dada mudança de valores dos textos e dos sujeitos implicados nessas leituras.

Tal mudança, de certo modo, deve-se ao fato desse "novo cenário literário contemporâneo" revelar crianças e jovens mais ativos e estimulados do que a de outros tempos: esse leitor criança ou jovem passa a ser visto como aquele que se constrói e é também construído capaz de entrar em contato com as significações propostas nos textos. Por sua vez, a relação de alteridade implicada no ato do enunciador (autor - do verbal e do visual) em detrimento do enunciatário (criança ou jovem leitor) determina um lugar de permanência desses leitores. Afinal, como bem afirma Bertrand, o leitor:

[...] não é mais aquela instância abstrata e universal, simplesmente pressuposta pelo advento de uma significação textual já existente, que se costuma chamar "receptor" ou "destinatário" da comunicação: ele é também e sobretudo um "centro do discurso", que constrói, interpreta, avalia, aprecia, compartilha ou rejeita as significações. (BERTRAND, 2003, p. 24).

$\mathrm{Na}$ contemporaneidade, a literatura infantil e mesmo a juvenil junto com as linguagens verbal e visual estão cada vez mais, intimamente, conectadas ao livro por meio de estratégias significativas em prol do conhecimento e formação de novos leitores para essa literatura que se faz ver como novidade, embora ainda mantenha o caráter moralizante e modelizante com que surgiu. É nesse cenário, portanto, que está inserida a literatura infantil e juvenil com a tarefa nada simples de contribuir para a formação de leitores.

Nota-se, com isso, que o próprio percurso da literatura, em vigor, revela aspectos capazes de ajudar a entender como e em que medida os textos produzidos para crianças e jovens, mesmo em face ao apelo das tecnologias atuais e das diversas formas de manifestação textual em suportes diferentes, continuam cumprindo um papel importante na formação do leitor dos novos tempos.

Da mesma maneira, percebe-se como a relação de integração entre linguagens como a verbal e a visual, a partir do período chamado por Nelly Novaes Coelho de explosão de multilinguagem, década de 70 no Brasil, colabora tanto para um discurso a favor da construção do saber-conhecer, quanto para um prazer estético como essência da arte literária que vai apontar novos rumos e se mostrar de maneira mais significativa na década de 90 . Esse fato, de certa maneira, instiga a percepção de tais relações na construção não só do valor 
inscrito no texto literário como fazer artístico, mas coloca a ver outros valores, temas e simbologias (do passado) com que essa literatura ainda circula entre crianças e jovens nesses novos tempos e organizações sociais.

Diante disso, e considerando as narrativas clássicas e seu surgimento no século XVII (período em que é possível se deparar com registros de narrativas "consagradas" pelas crianças em mídias; suportes impressos), pensar-se-á um determinado percurso: a atualização dessas histórias ou narrativas que adquirirem status de infantil no século XVIII, com a concepção de criança pensada por Rousseau (cujos reflexos são significativos no século XIX); e ainda uma nova percepção sobre a presença desses clássicos (cânones) no Brasil diante das mudanças e quebras de paradigmas ocorridas a partir da década de 70 , período conhecido como boom na literatura infantil e juvenil.

É válido pensar que na Idade Média e em grande parte da Idade Moderna, não havia nada que separasse a criança do adulto, ou seja, não havia universo adulto e universo infantil. E porque não existia distinção entre os espaços de convivência desses sujeitos, Dieter Richter diz que:

[...] não havia a "infância": nenhum espaço separado do "mundo adulto". As crianças trabalhavam e viviam junto com os adultos, testemunhavam os processos naturais da existência (nascimento, doença, morte), participavam junto deles da vida pública (política), nas festas, nas guerras, audiências, execuções etc., tendo assim seu lugar assegurado nas tradições culturais comuns: na narração de histórias, nos contos, nos jogos. (RICHTER, 1997, p. 36 apud ZILBERMAN, 2003, p. 36).

Tal contexto, reflete questões históricas, sociais e culturais importantes para a formação dos sujeitos criança e jovem de hoje. Logo, são essas questões que, retomadas aqui, servirão para repensar os valores inscritos nos novos textos infantis e juvenis e a interação com a nova criança e o novo jovem em pleno movimento de transformações e, consequentemente, afirmação de outras formas de expressão.

Nesse processo, observar-se um modo de reorganização das narrativas infantis clássicas, cujos textos vão sendo atualizados em suportes diversos (híbridos e sincréticos), permeados por múltiplas linguagens, refletindo a qualidade de um outro texto que se constitui a partir daquela matriz (do passado) e eleva a sua condição estética e plástica ao se reestruturar num tempo e espaço capazes de dialogar com seu interlocutor, a criança e o 
jovem, bem como com seus valores e expectativas enquanto sujeitos, não só do dever e do poder, mas do fazer e do ser num vasto e complexo contexto social e político do qual elas participam.

De acordo com as considerações, esse trabalho tem como objetivo principal investigar as transformações nos textos literários para crianças e jovens, a partir de mudanças nas relações sociais, além de verificar em que medida a literatura para esse público tem manifestado, no seu universo textual, novas maneiras de percepção sobre as narrativas primordiais ou clássicas, consolidadas como tal a partir do século XVII.

$\mathrm{Na}$ contemporaneidade, importa investigar, sobretudo a partir da segunda metade do século XX, no Brasil, a releitura do novo texto infantil, considerando o modo de ser dessa narrativa e seus valores, outrora marcada pela presença de uma pedagogia altamente moralizante e excludente que, agora, reorganiza novas estratégias de captação para retomar não só os clássicos ou histórias que caíram no gosto da criança e do jovem, no passado, mas para atualizar narrativas capazes de fazer parecer serem outras, dado o novo arranjo dessas novas histórias que intencionam, de modo significativo, evidenciar uma literatura com mais recursos de visualidade e plasticidade, bem como um modo de ser e de estar dessa nova criança e também do jovem num mundo de valores diversos e em trânsito, cujos reflexos corroboram um universo literário de vastas atualizações.

Assim, tomou-se como corpora, para se colocar em relação, as obras: Chapeuzinho Amarelo (2006), de Chico Buarque, ilustração de Ziraldo, Chapeuzinho Vermelho (1996), de Charles Perrault, Chapeuzinho Vermelho, dos irmãos Grimm (2009), Sapato de salto (2011), de Lygia Bojunga, Antecedentes de uma famosa história (2010), de Carolina Alonso, ilustração de Mariana Massarani, conto publicado em Não era uma vez: contos clássicos recontados - coletânea de autores latino-americanos, A outra história de Chapeuzinho Vermelho (2016), de Jean-Claude R. Alphen, ilustrada também por Jean-Claude R. Alphen e o conto Preciosidade (1991), de Clarice Lispector, texto publicado em Laços de família. Nesses corpora, percebe-se uma ênfase à literatura produzida para crianças, mas o título do presente trabalho se justifica em razão da linha tênue que vem separando o que se convencionou chamar de infância e adolescência.

Para a investigação, foram utilizados como fundamentação teórica elementos dos Estudos Comparados de Literatura, bem como de outras ciências da linguagem afins, além de 
estudos sobre a gênese e a História da Literatura Infantil e Juvenil. Com base em estudos já desenvolvidos sobre essa modalidade de textos, busca-se adentrar mais um pouco nessa floresta ainda vasta de textos literários que refletem valores humanos e sociais.

A Literatura Comparada, nesse caso, essencialmente entendida como uma maneira específica de interrogar os textos literários na sua interação com outros textos, em diferentes suportes, tempos e lugares vai auxiliar como um método de análise crítica. Tânia Carvalhal (Carvalhal \& Coutinho, 1994, p. 12), portanto, define o comparatismo da seguinte maneira: "A investigação de um mesmo problema em diferentes contextos literários permite que se ampliem os horizontes do conhecimento estético, ao mesmo tempo que, pela análise contrastiva, favorece a visão crítica das literaturas nacionais."

Tomando-se o significativo campo de investigações, discussões e sondagens, via análises de textos literários selecionados para esse fim, é apresentada no primeiro capítulo uma reflexão sobre o papel da literatura infantil na contemporaneidade, pensando-se sua consolidação como gênero literário, suas diferentes formas de representação, bem como seus processos de transformação de valores em curso - textos literários atravessados por interdiscursos e por um fazer estético em constante diálogo e atualizações - , observandose, assim, que para se refazer a literatura precisou dar "um mergulho vertical na linguagem literária”.

No segundo capítulo, buscou-se fazer uma retomada do conto de fada enquanto forma que fascina, observando suas características primeiras e uma dada projeção que garante sua permanência na contemporaneidade a partir, sobretudo, da atualização ou representação de narrativas clássicas em novos suportes textuais e diferentes linguagens. Nesse tocante, percebeu-se a interação da literatura infantil com outros leitores inscritos, pela familiaridade ou reconhecimento da narrativa primordial, no suporte audiovisual.

Já no terceiro capítulo (e seus desdobramentos) verifica-se que há, nas transformações sociais e seus reflexos nas representações projetadas pela literatura, um olhar que intenciona captar uma dada realidade literária para a criança e para o jovem e seus valores ou desvalores em trânsito. Nesse sentido, as obras analisadas (clássicos literários postos em relação com obras do presente) findam por corroborar um panorama de atualizações, discursos ou paixões em oposição como bem e mal, aparência e essência, revestidas como novas temáticas que dialogam com os conflitos internos e externos do seu 
público leitor, além de outros aspectos inscritos no conto de fada e maravilhoso do novo século.

O percurso realizado, de certo modo, apresenta uma maneira diferente de ser da literatura infantil e juvenil, ainda que esta última apareça em menor escala na discussão teórica, na contemporaneidade por meio de uma ruptura com o próprio tempo e não pela relação de adesão com ele, o que decerto impediria um olhar diferente sobre os textos do passado em relação aos do presente.

E é diante dessa fratura que se alcançam outros textos, tempos e valores inscritos no século XXI, cuja projeção nos textos literários anuncia novos arranjos e recursos que fazem ser e parecer novo o texto da literatura infantil e juvenil, principalmente pelo caráter de originalidade com que circula, ou seja, pela nova vestimenta com que essa literatura apresenta os conflitos que atravessaram tempos, sociedades, sujeitos e valores culturais, mostrando que as novas atualizações desses textos literários do passado, em sintonia com os do presente, revelam problemas humanos ainda em movimento de transformação. 


\section{LITERATURA INFANTIL: TRANSFORMAÇÕES EM CURSO}

"No processo de transformação dos valores de base da Sociedade, "o novo ensino" vê-se investido de uma dupla tarefa: transmitir a Tradição, no que ela conserva de válido, e incentivar a invenção do novo que rompe com a herança recebida." (COELHO, 2000, p. 136).

Refletir sobre o papel da literatura infantil na contemporaneidade, remete considerá-la desde os remotos indícios de seu surgimento até o momento em que as práticas pedagógicas vão se impondo na educação, principalmente após a segunda metade do século XIX. Nesse percurso, ainda hoje, é possível se deparar com questionamentos sobre o que seria o caráter da literatura infantil: instrumento pedagógico ou arte? E, diante desse contexto, toma-se o olhar norteador de Coelho sobre a questão:

Literatura infantil é, antes de tudo, literatura; ou melhor, a arte: fenômeno de criatividade que representa o mundo, o homem, a vida, através da palavra. Funde os sonhos e a vida prática, o imaginário e o real, os ideais e sua possível/impossível realização. (COELHO, 2000, p. 9).

Da mesma forma, delimitar o que se entende ou se chama de literatura tem sido tema principal de vastos trabalhos de pesquisa, assim como presença constante em debates acadêmicos. Afinal, o que é literatura? E para tal, considera-se a concepção de Antonio Candido. Entendida, nesse contexto, como inclusiva ou global:

Chamarei de literatura, da maneira mais ampla possível, todas as criações de toque poético, ficcional ou dramático em todos os níveis de uma sociedade, em todos os tipos de cultura, desde o que chamamos folclore, lenda, chiste, até as formas mais complexas e difíceis da produção escrita das grandes civilizações. (CANDIDO, 2004, p. 174).

A partir disso, e considerando a transformação dos valores de base da literatura infantil e seu desenrolar diretamente ligado à educação de crianças, pensar-se-á uma dada constituição de literatura infantil e formação de sujeitos à luz, nesse primeiro momento, de recortes de alguns livros de caráter verbo-visual em que o papel da ilustração, embora inicialmente exercesse uma função meramente ilustrativa, ornamental ou de complementação das informações escritas vai desdobrando-se numa constante evolução 
como suporte midiático que a constrói também pela necessidade de atualizar conteúdos. Tais textos, que surgem no século XVII, eram destinados às crianças ainda que estas obras necessariamente, como se sabe, não cumprissem a rigor esse papel.

Nessa rota, é importante perceber como a ascenção de determinadas narrativas populares, através dos tempos, continuam suscitando universos que se mantêm vivos e atuantes no imaginário presente, assim como também inscrevem ou revigoram modos de pensamento e articulação de papéis sociais e culturais, tão marcados nos textos infantis que desembocam no século XXI, o que decerto revela novas concepções de criança e de literatura infantil.

Isso remete, de maneira cuidadosa, a pensar que essa literatura infantil se organiza em função das mudanças ocorridas em variados contextos e épocas, principalmente no que diz respeito ao campo da comunicação, levando-se a considerar o início do século XX como um período significativo no que tange às transformações de valores ou desvalores, além dos novos aspectos que contribuem para as mudanças ocorridas num tipo de literatura que se apresenta como gênero literário infantil, cujo alvo teoricamente é a criança.

Um ponto relevante, na contemporaneidade, é observar em que medida a necessidade de integração entre linguagens, mais detidamente focalizando as linguagens verbal e visual como expressões que geram um aspecto de novidade, mobilizam reflexões que não cabiam anteriormente nos textos marcadamente moralizantes. Sobretudo, considerando-se a interatividade gerada pela linguagem visual, cada vez mais presente nos textos, e, mais particularmente, considerando um tipo de criança capaz de lidar com esse universo, o que aponta para uma justificativa em função da necessidade de se desenvolver mecanismos que explorem cada vez mais o campo da visualidade, posto a própria criança já ter desvendado uma capacidade de leitura (decodificação) que ela pode operar diante de um arranjo verbo-visual.

Diante disso, cabe pensar que o verbal passa a ser, de certa forma, posto lado a lado com outra linguagem (a visual, nesse caso) em que é possível ver o valor de cada uma individualmente, ou seja, em que verbal e visual numa relação de justa medida corroboram, juntas, uma unidade de sentido à obra literária. E é dessa maneira que se pode atestar que ambas as linguagens podem instaurar um universo criativo (por meio de várias linguagens) 
e maravilhoso (por meio do ato libertador da leitura) em que, diante desse processo, o público-leitor é guiado a sentir.

Autores dos textos visuais, os ilustradores, nesse espaço, ganham terreno maior e vão se fazendo, cada vez mais, presentes num lugar - livro, predominantemente habitado e reconhecido, por muito tempo, apenas pelos autores dos textos verbais. A convivência entre esses autores, contudo, proporciona uma aproximação que contribui para o estar junto das linguagens verbal e visual no livro infantil, assim como para suas multiplicidades de sentidos. Uma nova ordem ou espécie de acordo se estabelece. E ambas as linguagens parecem se comprometer por um futuro próspero e duradouro da literatura e de seus leitores.

$\mathrm{Na}$ contemporaneidade, verifica-se que a necessidade de integração entre as linguagens verbal e visual, cada vez mais, ganha força com o avanço tecnológico e a consequente interação gerada pelo mundo imagético. O cenário projetado, nessa época, evidencia um público apto a lidar com este universo por meio da capacidade de leitura diante das imagens e vice-versa.

A literatura infantil e juvenil, para adequar-se à nova realidade, vem trabalhando a exploração do universo verbal e visual. Observa-se que cada linguagem, sem abdicar de seu valor e nem elevar sua condição hierárquica quando posta em relação numa mesma página, pode corroborar uma unidade de sentido global ao texto literário infantil. Um bom exemplo dessa possibilidade de integração entre linguagens, dentre muitos outros que surgiram nesse novo período da literatura infantil (com mais recursos de visualidade e plasticidade) é o livro Flicts, de Ziraldo, publicado pela primeira vez em 1969 (figuras 1 e 2 - ilustrações da edição de 2006 utilizadas nesse trabalho). Sobre essa obra e seu novo valor, Zilberman se manifesta dizendo que:

Ao lançar Flicts, em 1969, Ziraldo talvez não previsse a revolução que provocava na ilustração de livros infantis brasileiros. Naquela obra, as imagens, não figurativas, não correspondem a um ornamento do texto, complementando as informações escritas; pelo contrário, as cores é que falam, competindo à expressão verbal esclarecer o assunto e explicar o conflito, vivenciado pelo herói, ele mesmo um pigmento que não encontra lugar no universo dos tons pictóricos. (ZILBERMAN, 2014, p. 159). 
Figura 1 -Flicts: primeira capa

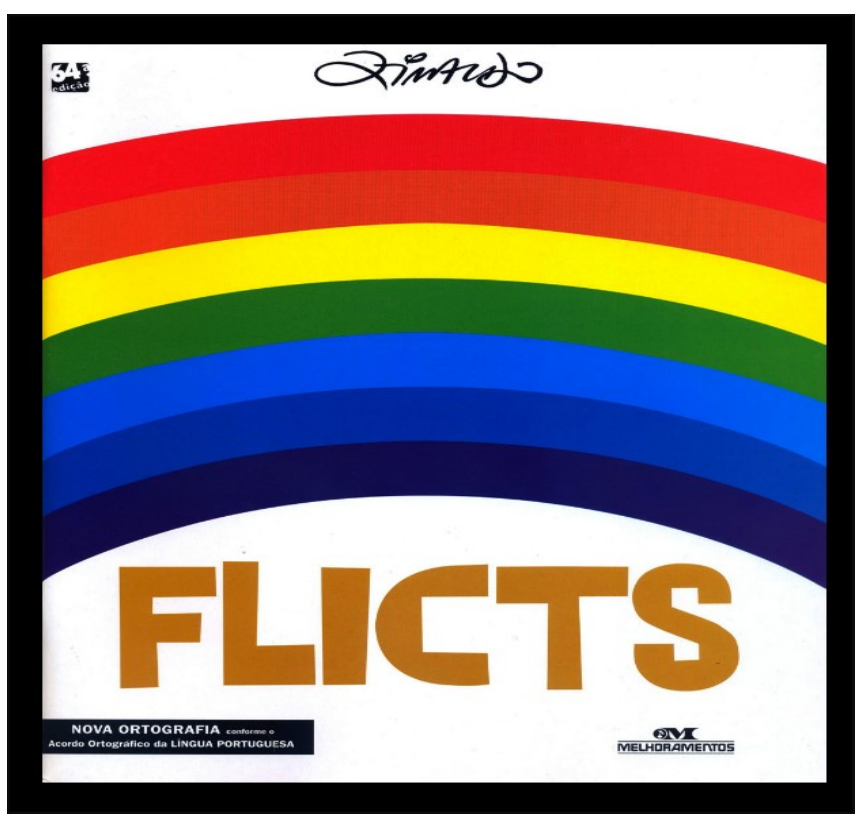

Fonte: Ziraldo (Edição de 2006)

Figura 2 - Flicts: página de abertura

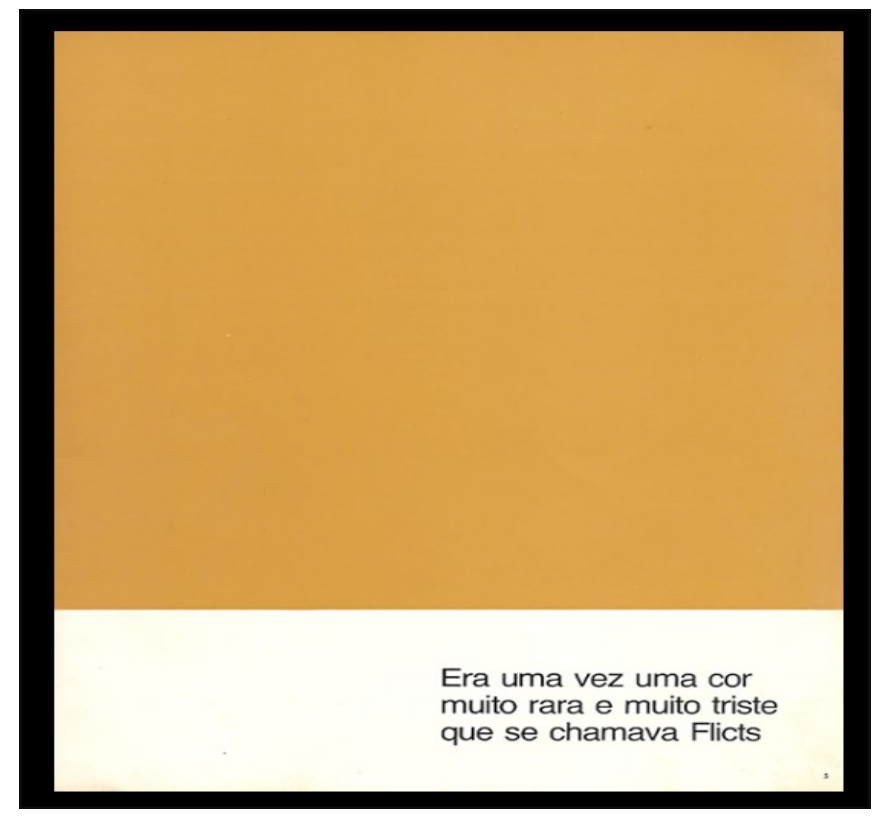

Fonte: Ziraldo (Edição de 2006) 
A narrativa mostrada no livro Flicts (figura 1) é apresentada por um narrador onisciente e onipresente com foco narrativo em terceira pessoa que, além de criar efeitos de sentido de tempo indeterminado por meio do tempo marcado no passado, recupera no início do primeiro enunciado do livro (figura 2), portanto o de abertura, uma estrutura linguística bem comum do conto de fada "Era uma vez", instaurando o seu conteúdo como obra ficcional "acontecida" no pretérito imperfeito, mas com uma duratividade ${ }^{2}$ pontuada nos semas com os quais se constrói esse tempo verbal "era", "chamava", "tinha". Assim, o início da narrativa de Flicts nos remete a uma ficção própria mesmo do conto de fada, cujos termos, conforme Jesualdo, têm a seguinte origem:

Conto: tradução de fatos ou invenções geralmente da imaginação de seu criador, recolhidos da experiência popular, inspirados em sucessos reais, por vezes na História, em que esse sentido fatalista e inexorável da lenda já não pressiona o desenvolvimento do conhecimento que se transmite [...] da palavra, em imagem viva e animada, surgiu o mito e deste nasceu o conto. $[\ldots]$

Fada: a palavra 'fada' tem raiz grega. Indica o que brilha e dessa raiz derivam as demais desinências que contêm certa ideia de brilho. Assim, fábula, falar, fatalidade, fado e fada, derivadas ambas do latim fatum, que provém da mesma raiz grega. Esta raiz parece explicar-nos que quem narra tais contos procura fazer brilhar suas ideias, as expõe nas fábulas; o destino do homem, o fatum, é o brilho que lhe dá realce e o determina. (JESUALDO, 1978, p. 112-116).

Segundo o ponto de vista do autor, baseado na etimologia das palavras, pode-se dizer, então, que os contos de fada são discursos em que "ideias brilham". E de acordo com Discini (1995, p. 82), ao comentar o conto maravilhoso, os contos de fada brilham porque persuadem de algum modo, manipulando o destinatário a acreditar e a fazer algo.

Como se viu, foi a partir da leitura intertextual, marcada pelo "Era uma vez" que se apreendeu, de uma unidade de sentido, o todo de sentido da obra que se mostra por meio do percurso narrativo do sujeito Flicts em busca do seu objeto-valor inclusão, passando, por

\footnotetext{
${ }^{2}$ Trata-se de uma referência ao tempo linguístico; o tempo instaurado, pelo locutor/enunciador, no momento da enunciação, aceito e compartilhado pelo seu interlocutor/enunciatário, o que nesse caso cria a ideia de tempo inacabado, estático, não limitado. Ver mais em FIORIN, José L. As Astúcias da Enunciação: as categorias de pessoa, espaço e tempo. $2^{\mathrm{a}}$ ed. São Paulo: Editora Ática S.A., 2008.
} 
sua vez, por etapas ou fases de segregação e mesmo de exclusão (situações que remetem, intertextualmente, ao conto maravilhoso - O Patinho Feio - de Andersen). Tal busca do herói (representado no texto por um nome e uma cor) nasce do desejo de pertencer a algum espaço ou mesmo ter aceitação no universo, uma vez que as várias tentativas são seguidas de negação que só aumentam seu conflito interior. Sobre isso, Zilberman comenta:

Flicts tornou-se assim, metáfora não apenas do excluído, mas do reprimido que cada um deve aceitar, se quiser conviver melhor consigo mesmo. A riqueza das imagens tornou a narrativa paradigmática das possibilidades de representar o mundo interior das criaturas de modo compreensível, sem ser simplista. (ZILBERMAN, 2014, p. 69-70).

Nesse percurso, é possível verificar um desdobramento em que tanto obra quanto criança se transformam diante do tempo e sociedades inscritas nas obras ditas para ela e vice-versa. E é considerando esse contexto que se voltará o olhar, a partir do século XVII, para se verificar em que medida as obras do presente foram sendo atualizadas, atendendo a um público cada vez mais exigente e conectado com o seu tempo e suas transformações.

A literatura infantil, entendida como gênero, surge simultaneamente na França e Inglaterra, assim também um certo sentimento de infância que vai permear o século XVII. Contos da Mamãe Gansa, de Charles Perrault, publicada em 1697, marca, nesse cenário, o início da circulação de textos oficialmente para crianças. Perrault ganha notoriedade como autor e fundador da literatura infantil, sendo considerado, por muitos escritores de sua época, o grande pioneiro nesse gênero. $\mathrm{O}$ certo é que Perrault mesmo não intencionando, num primeiro momento, escrever textos para crianças, tornou-se uma referência inquestionável como folclorista e guardião da tradição popular. $\mathrm{O}$ termo folclore mencionado no decorrer deste trabalho:

[...] pode ser entendido como o "conjunto de costumes, lendas, provérbios, manifestações artísticas em geral, preservado, através da tradição oral, por um povo", quanto como a "ciência das tradições, dos usos e da arte popular de um país ou região". Presume por uma parte, um patrimônio popular já existente, veiculado sobretudo pela forma oral, composto principalmente por contos [...], mas também por frases, canções, danças, atitudes; de outra, supõe a descrição desse material, responsabilidade assumida por uma ciência e seus estudiosos que se dedicaram a ela, como fizeram no Brasil, por exemplo, Mário de Andrade e Luís Câmara Cascudo (1898-1986), modernistas que nunca deixaram de 
examinar com carinho nossa cultura e tradições. (ZILBERMAN, 2014, p. 97-98).

Não obstante, Gustave Doré, conhecedor desse valor inscrito nos contos de Perrault, assume o desejo de participar de uma cultura popular, moderna e a favor do progresso nas artes ou, por assim dizer, participa de uma espécie de manifesto contra as instituições acadêmicas que regulavam a produção cultural nesse período. E, dessa maneira, portanto, ilustra Les contes de Perrault, edição Hetzel-Stahl de 1862 (figura 3), um trabalho significativo em que Doré, além da obra de Perrault, cumpre o projeto de ilustrar grandes autores do cânone da literatura universal. O livro editado por Hetzel-Stahl, embora apresentado por um projeto editorial de luxo (e, portanto, acessível somente a um grupo seleto), caracteriza-se pela qualidade plástica como um objeto de arte em que texto verbal (palavra) e texto visual (ilustração) são colocados em "pé de igualdade". Tony Gheeraert (2005) apresenta a edição de luxo destacando-a pelo "prazer de se conhecer uma bela obra de arte"3.

Figura 3. - Les contes de Perrault

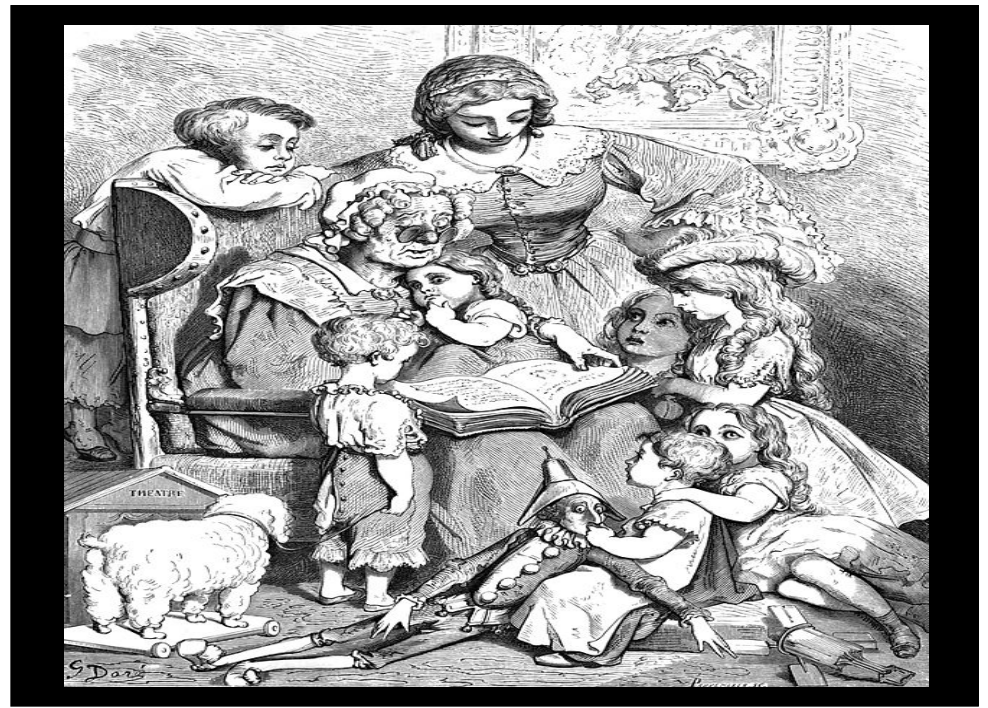

Fonte: Doré $(1862)^{4}$

3 "Perrault illustré par Doré, ou la perfection du contresens", conferência pronunciada em novembro de 2005, Maromme la Maine, IUFM de Rouen e publicada no site da Academia de Rouen em 2007.

${ }^{4}$ Fonte da imagem: https://pt.wikipedia.org/wiki/Literatura_oral 
Notadamente, o século XVII (século em que a literatura infantil passou a ser escrita especificamente como tal) foi primordial no que corresponde dizer sobre um período rico em obras importantes para a literatura infantil, contudo é fato que a reconhecida Idade de Ouro se deu no século XVIII, considerando para isso a divisão entre universos adulto e infantil ${ }^{5}$ ocorrida nessa época, o que, de certa maneira, fez repensar o tratamento da criança como um adulto em miniatura ${ }^{6}$ em outras sociedades e culturas.

No Brasil, começo do século XX, os Contos da Carochinha (figuras 4 e 5), de 1896, do jornalista português Alberto Figueiredo Pimentel, surgem como um esforço do livreiro e do editor Pedro Silva Quaresma em resolver o conflito que envolvia o leitor infantil brasileiro e a literatura infantil que chegava de Portugal com uma linguagem que não se aproximava desse sujeito. Sendo assim, e considerando a amizade por Pimentel, é que Quaresma encomenda toda uma biblioteca de livros que falassem diretamente às crianças brasileiras.

Contos da Carochinha contava com uma compilação de histórias, 40 contos, dentre os quais alguns foram baseados no folclore português e brasileiro, além das adaptações de narrativas populares comuns na Europa Medieval. As narrativas em Contos da Carochinha foram transmitidas de forma oral e escrita e, porque mantinham uma estrutura marcada pelo caráter fabular, ficavam encarregadas dos conselhos e lições morais.

A publicação desse livro é considerada um momento importante para a literatura infantil no Brasil, uma vez que antes dele todos os livros infantis eram editados em Portugal. Nesse cenário, a figura de Quaresma vai se destacar pelo notório trabalho na edição das obras infantis, mostrando que, apesar de haver outros livros destinados ao

\footnotetext{
${ }^{5}$ Ariès Philippe observa que os vestuários usados por crianças e adultos mostravam a indiferença pelas características da fase da infância, uma vez que na Idade Média e até bem entrados os anos da Idade Moderna, tão logo as crianças deixassem de usar fraldas passavam a se vestir como adultos. As mudanças nesse quadro só vão acontecer a partir do século XVII. Ver mais sobre o assunto em: ÀRIES, Philippe. História social da criança e da infância. Trad. Dora Flaksman, 2. ed. Rio de Janeiro: LTC Livros Técnicos e Científicos Editora S/A, 1981.

${ }^{6}$ Essa concepção de criança como um adulto em miniatura foi objeto de crítica e estudo do filósofo e escritor Jean-Jacques Rosseau, após anos de reflexão, em sua obra Emílio ou Da Educação, de 1762, cuja doutrina naturalista, fundamentada em ideias religiosas vai exercer influência ampla não só em sua época, mas também em períodos posteriores, apesar de condenado pelo Tribunal de Justiça, em Paris (11/6/1762). Ver mais em Panorama histórico da literatura infantil/juvenil: das origens indo-europeias ao Brasil contemporâneo, de Nelly Novaes Coelho.
} 
público infantil, seus exemplares eram especiais, pois acreditava que estes organizavam uma espécie de encanto particular, como se fossem únicos e exclusivos. No entanto, tais efeitos de sentido no discurso organizado por Pimentel, no prefácio do exemplar Contos da Carochinha, findam por confirmar os mesmos valores com que circulavam a maioria das obras ou, por assim dizer, legitimam o cuidado pedagógico e a preocupação moralizante na formação do jovem leitor dessa época:

As obras, nesse gênero, que havia em português, ou eram mal escritas, e até imorais, ou destinavam-se ao estudo de nossa nacionalidade. [...] ao mesmo tempo que deleita as crianças, interessando-as com a narração de contos morais muito bem traçados, lhes desperta os sentimentos do Bem, da Religião e da Caridade, principais elementos da educação da infância. (PIMENTEL, 1959, p. 7-8).

Nesse cenário, ainda que a iniciativa de Quaresma tenha se destacado pelo esforço em resolver a questão do que Arroyo (2011, p. 149) chamou de: "nacionalização da problemática da literatura infantil brasileira - quanto ao tema e quanto à expressão (...)", continuava-se o "didatismo moralizante" ${ }^{\text {"7 }}$ da literatura, fato confirmado pelo esforço mal sucedido em função de se modificar o panorama da literatura infantil no Brasil, uma vez que esta continuou recebendo influências, sobretudo de Portugal, França e Inglaterra. Situação essa constatada por Gilberto Freyre (Freyre apud Arroyo, p.149, 2011), ainda em 1922, ao pontuar a insuficiência tanto da literatura infantil brasileira, quanto da língua portuguesa: "o brasileiro passa pela meninice quase sem ser menino. Faltam-lhe brinquedos. Faltam-lhe livros". Uma situação que o respeitado sociólogo só iria considerar modificada a partir da presença de Monteiro Lobato, nesse cenário.

\footnotetext{
${ }^{7}$ Termo utilizado por Gregorin Filho em seu texto Literatura infantil: um percurso em busca da expressão artística, in: GREGORIN FILHO, José Nicolau, PINA, Patricia Kátia da Costa, MICHELLI Regina Silva (orgs.). A Literatura infantil e juvenil hoje: múltiplos olhares, diversas leituras. Rio de Janeiro: Dialogarts, 2011.
} 
Figura 4 - Contos da Carochinha

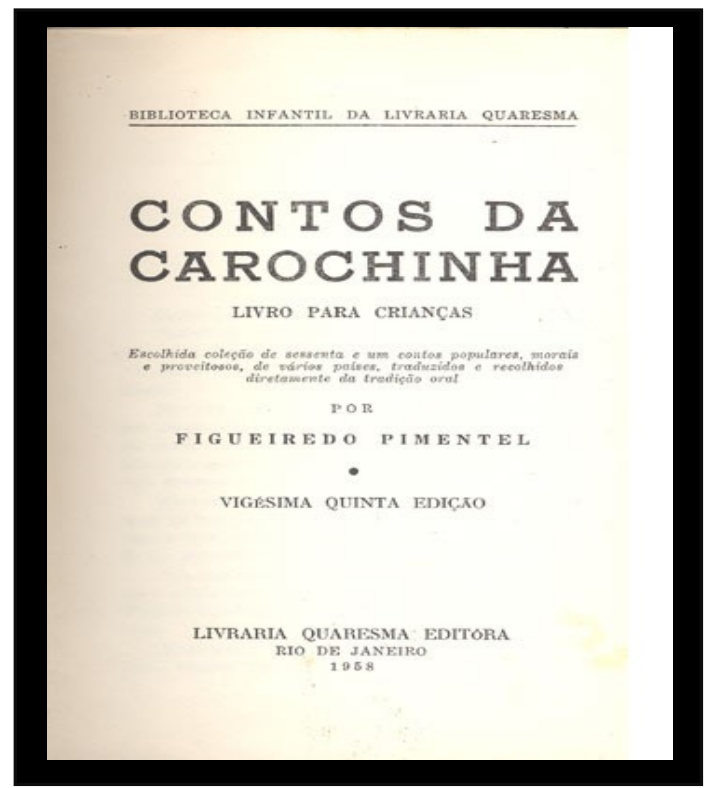

Pimentel $(1958)^{8}$

Figura 5 - Contos da Carochinha

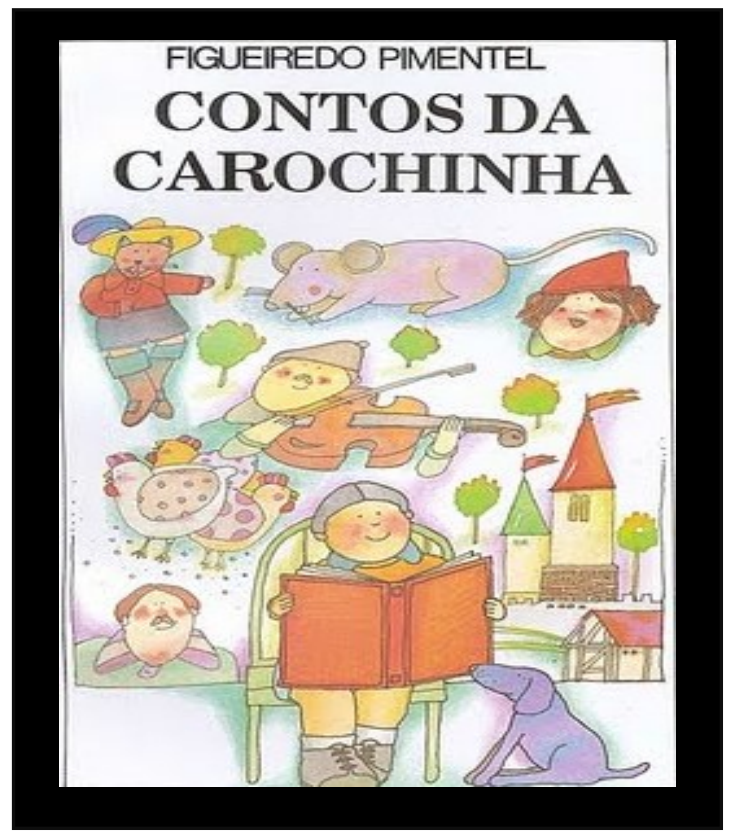

Fonte: Pimentel (1992)

\footnotetext{
${ }^{8}$ Fonte da imagem: https://sebodomessias.com.br/imagens/produtos/23/233962 959.jpg

${ }^{9}$ Fonte da imagem: $\underline{\text { https://megaarquivo.com/2012/11/16/7087-de-onde-surgiu-a-expressao- }}$ contos-da-carochinha/
} 
De outro modo, é pela significativa manutenção dos valores em processo de atualização e passíveis de diálogo com obras que compõem o corpo dessa pesquisa, que vai se retomar o clássico História da Dona Baratinha, um dos contos reunidos na obra Contos da Carochinha. Ele foi publicado pela primeira vez em 1890, com o título original História da Carochinha, pelo linguista e pedagogo português Adolfo Coelho que, tal qual Perrault e os irmãos Grimm, recolheu da tradição oral e transcreveu diversos contos portugueses tradicionais que caíram no gosto do leitor.

Tal obra, como se disse, atualizada pelo jornalista português Alberto Figueiredo Pimentel, responsável pela adaptação também no nome da personagem, de Carochinha (diminutivo de carocha, um besouro dourado originário do norte do Portugal) para Baratinha (diminutivo de barata, um inseto comum a todas as regiões do país), ainda ganhou novos investimentos valorativos com a autora Ana Maria Machado, que em sua obra Dona Baratinha (figura 6), com ilustração de Maria Eugênia, publicada pela primeira vez em $1996^{10}$, reconta aquela história do passado, reconstruindo um novo lugar; ponto de vista para se ver a personagem principal, Dona Baratinha - representação do feminino -, ao mesmo tempo em que reitera a tradição dos bestiários.

Figura 6 - Dona Baratinha: primeira capa

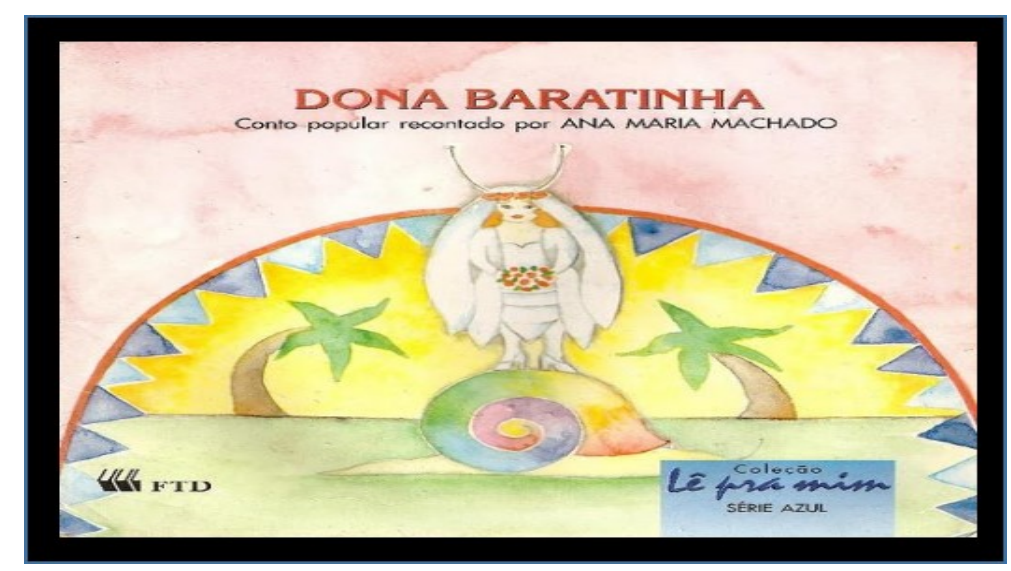

Fonte: Machado (2004)

\footnotetext{
${ }^{10}$ Em 2002, esta obra de Ana Maria Machado, usando o mesmo título citado, fez parte do primeiro volume de uma nova coleção intitulada: Histórias à brasileira que reuniu dez contos tradicionais recontados, ao estilo brasileiro, pela autora ganhadora do Hans Christian Andersen e ilustrados por Odilon Moraes.
} 
Outros aspectos importantes e curiosos, nesse novo arranjo de Machado, são trazidos à tona a partir da manifestação de traços identitários da obra que passa a ser entendida como brasileira ou nacional por meio de elementos presentes nessa cultura e que ela manifesta em seu texto, tal qual a feijoada - como escolha do prato principal a ser servido no casamento da Dona Baratinha com o João Ratão - que a partir do anos 1930, paralelamente a um processo de desafricanização de vários elementos culturais, passa a ser:

[...] destacada como "um prato típico da culinária brasileira". Originalmente conhecida como comida de escravos, a feijoada se converte em "prato nacional", carregando consigo a representação simbólica da mestiçagem. O feijão (preto) e o arroz (branco) remetem metaforicamente aos dois grandes segmentos formadores da população. A eles se juntam a couve (o verde de nossas matas), a laranja (a cor de nossas riquezas). (SCHWARCZ, 2009, p. 97-98).

Observa-se que a narrativa de Machado não foge ao "Era uma vez", frase inicial que estabelece o contrato com o maravilhoso. A personagem principal, portanto, Dona Baratinha, antropomorfizada, é apresentada com as características e ocupações da mulher dona de casa, como pode ser observado por meio da ação de varrer a casa, anunciada pela linguagem verbal já na página de abertura do conto (figura 7): "Era uma vez uma baratinha que estava varrendo a casa e encontrou uma moeda.". 
Figura 7 - Dona Baratinha: página de abertura

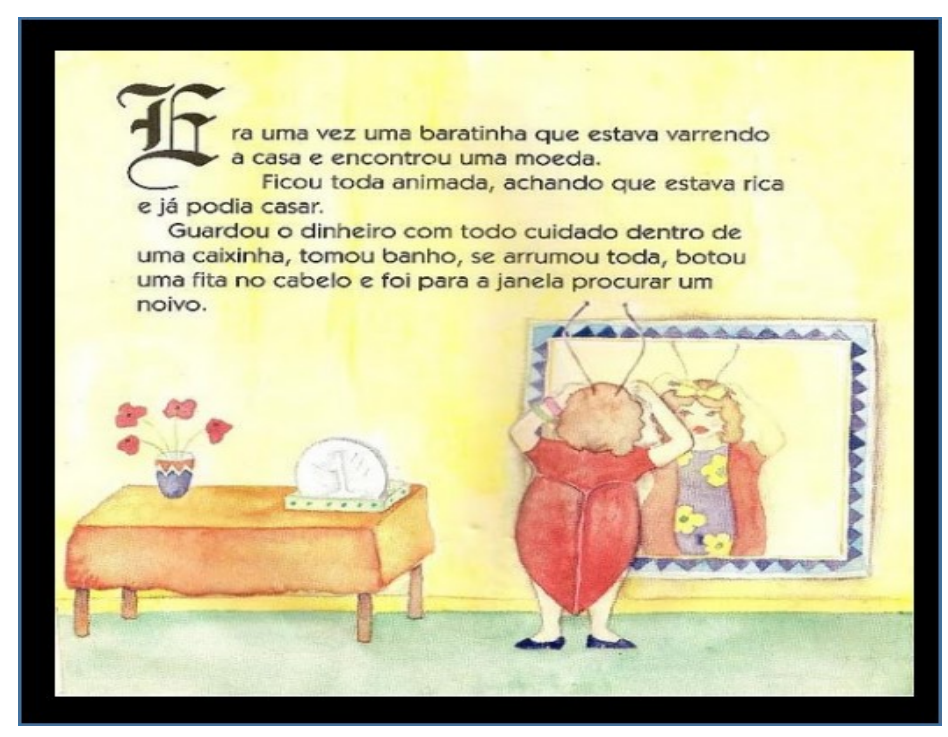

Fonte: Machado (2004)

É importante pensar, que nas primeiras versões dessa narrativa, devido ao contexto histórico e cultural, é compreensível que o casamento ainda fosse o objetivo principal na vida da mulher do século XIX. No entanto, a personagem recriada por Ana Maria Machado é inscrita como um sujeito moderno, e ainda que também (como na versão portuguesa) acene para o casamento, na primeira oportunidade em que se vê com recurso financeiro (dote), não confirma tal ato como objetivo principal.

Por sua vez, é perceptível um conflito social mesmo nessa nova história da Dona Baratinha, em que Machado contextualiza o conto no Brasil dos anos 90, ou seja, numa sociedade brasileira em plena mutação e desenvolvimento, atrelados às mudanças do século XX, mas, paradoxalmente, apegada a valores tradicionais como o casamento e a religião - ideologias que sempre estiveram presentes como valores determinantes nos contextos das culturas e das sociedades de todos os tempos, principalmente na educação feminina (marca presentificada pela linguagem visual na capa da obra, de Ana Maria Machado).

No tecer das comparações, observa-se, então, a passagem que serve como mote para as duas narrativas (a de Pimentel e a de Machado) - é justamente quando se mostra o momento em que Dona Baratinha acha a moeda, o que na versão de Pimentel representa a 
situação de um sujeito feminino incapaz de tomar decisões e que, portanto, precisa de ajuda e deve realizar uma espécie de consulta para dar destino ao achado. E, como não podia deixar de ser, nessa época, todas as pessoas consultadas (as vizinhas) aconselham Dona Baratinha para que se case, e é assim que ela vai parar na janela procurando um marido (figura 8).Veja-se em Machado (1996, p. 57) : “Quem quer casar com a Dona Baratinha que tem fita no cabelo e dinheiro na caixinha?".

Figura 8 - Dona Baratinha na janela

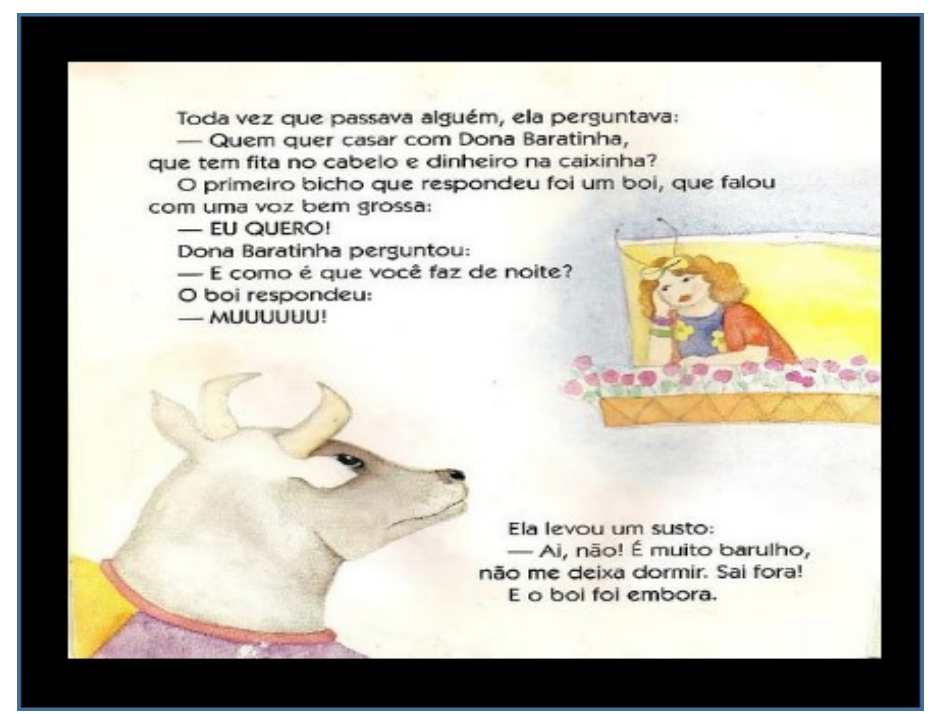

Fonte: Machado (2004)

$\mathrm{Na}$ versão de Machado, a personagem Dona Baratinha ao achar o dinheiro (figura 7), diferentemente da versão de Pimentel, sabe exatamente o que fazer com ele, demonstrando certa independência e autonomia, apesar de desejar ser vista igualmente à outra, pelos valores da beleza, aparência, natureza (fita no cabelo) e ascensão social e cultural (dinheiro na caixinha) - imagem da mulher que o século XX iria herdar.

De certa forma, os valores éticos ideológicos presentes nesse conto maravilhoso ressaltam a mulher como uma ambiguidade a ser explorada, uma vez que ela, desde as narrativas primordiais, é causa de bem e de mal. A esse respeito, Coelho aponta para características cristalizadas da mulher que, de modo particular, remetem à construção da figura da fada em contraste com a figura da bruxa: 
A grande mediadora da possível ascensão do homem na escala social é a mulher. Casando-se com a "filha do rei" ou do "nobre abastado", o indivíduo pobre ou plebeu automaticamente enobrece e se torna poderoso. (Esse sistema foi, posteriormente, incorporado pela estrutura romanesca romântica).

As qualidades exigidas à mulher são: beleza, modéstia, pureza, obediência, recato... e total submissão ao homem (pai, marido, irmão, etc.). [...]. (COELHO, 2000, p.180).

Por outro lado, em Machado (figura 9), ao contrário da versão de Pimentel, a personagem Dona Baratinha não se entristece, perde o sentido da vida ou decide que nunca mais irá se casar quando o futuro marido morre "afogado na feijoada":

Coitado do ratinho! Mas para mim foi uma sorte. Não podia dar certo um casamento com um noivo que gosta mais de feijão do que de mim. Melhor eu ficar sozinha e gastar meu dinheiro para me divertir. E assim fez. (MACHADO, 1996, p. 57).

Esse fato, de algum modo, coloca o sujeito mulher em estado de liberdade e rompe com as ideologias marcadas naquele contexto em que uma mulher sem se casar não poderia ser capaz de ter uma vida decente, ser independente ou mesmo respeitada pela sociedade.

E, na contramão de um tempo entrelaçado com outro dá-se voz a uma Dona Baratinha moderna que, rompendo pouco a pouco com o passado, vai manifestar a felicidade feminina como um ato de liberdade longe de estar centrado única e exclusivamente no casamento, mesmo que este ainda carregue a força da tradição.

A personagem é pontual ao deixar revelar uma consciência sobre si (alteridade) como sujeito social que descobre sua existência no mundo, seu lugar, e tal qual a personagem Flicts, de Ziraldo (sujeito excluído, segregado, marginalizado), ela também quer ter valor, ter reconhecimento e existir, fato que a concretiza como sujeito do fazer e do ser. 
Figura 9 - Dona Baratinha: página final

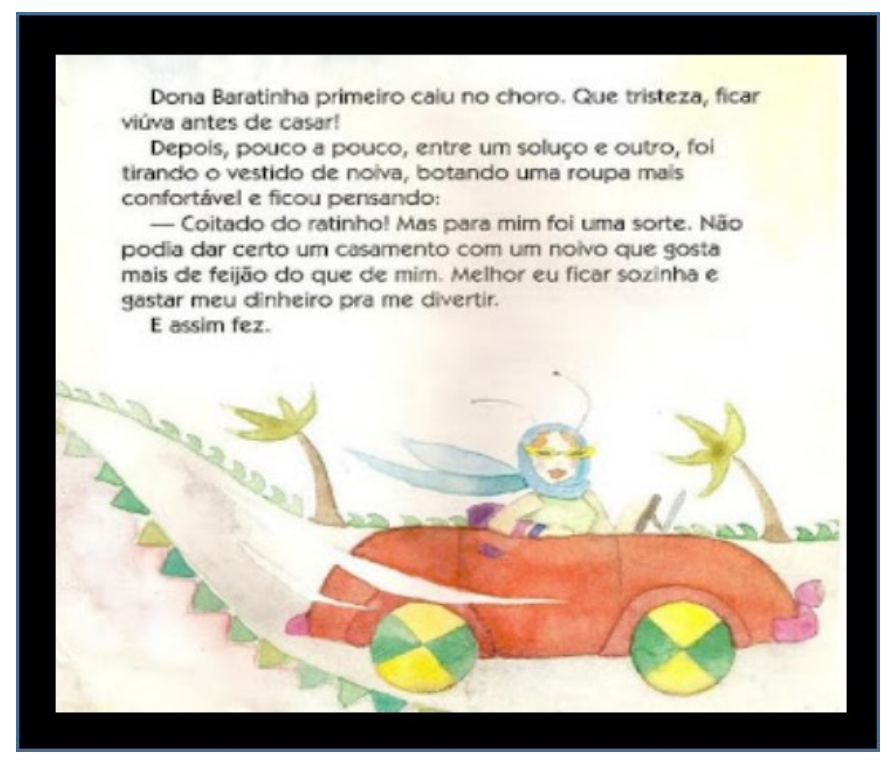

Fonte: Machado (2004)

Ao final da narrativa de Machado, é possível perceber que a autora instiga a percepção ativa de um leitor já projetado no texto, ao romper, de certa forma, com a submissão feminina quase velada, inscrita naquele outro texto, o de Pimentel, que atravessou gerações. Dessa feita, Machado subverte uma ideologia forjada pela relação de desigualdade latente a que era submetida a mulher num determinado tempo, revigorando, de certa forma, valores para o novo sujeito leitor de seu texto e aproximando-o de um mundo em constante mutação e quebra de paradigmas.

É, portanto, no Brasil do final do século XIX que se encontra um determinado marco político que refletirá sobremaneira nas questões sociais e, consequentemente, no que que se entenderá como literatura infantil brasileira a partir daqui. Nesse período, começavase um certo anseio pela migração para o regime republicano, que deveria seguir o modelo de muitos países europeus, uma vez que a monarquia não atendia mais as expectativas de um povo desejoso pela ideia de poder escolher seus governantes e exercer a cidadania prevista pelo ato democrático.

Sobretudo, considerando-se que o país progredia em população e variedade cultural e, decerto, isso implicava em também se organizar de outras maneiras. Essa nova organização social inscreveu uma classe média desejosa por mudanças, as quais foram 
manifestadas em tom de reinvindicação e clamavam por liberdade política, acesso a melhores negócios e mudanças educacionais. Tais assinalaram as expectativas de um grupo social emergente, cujas exigências desencadearam os primeiros livros escritos para crianças.

O fato é que, no Brasil, a literatura infantil ainda importava textos estrangeiros dando continuidade ao que se entendia como literatura para crianças. E assim, fazia-se a manutenção do caráter pedagógico centrado na formação do cidadão-criança, não muito diferente do que ocorria na Europa, ou seja, a tentativa literária concretizava-se pelo caráter meramente educacional preocupado, predominantemente, em dar conta de princípios morais. Coelho confere a isto o fato dessa literatura ser:

Resultante de uma "pedagogia" maternal que se difunde no século XIX (pela qual a escola devia ser continuadora do lar, na formação das crianças) surge uma abundante literatura moralizante, informativa e pueril, que pretendia auxiliar os infantes a se prepararem o mais depressa possível para a vida adulta. (Eram os "tesouros", os "exemplários", os "ramalhetes" ...). A passagem da infância para a vida adulta se fazia quase sem transição. A criança era ainda vista como um "adulto em miniatura". Daí os raros livros escritos especialmente para leitores da faixa intermediária, puberdade e adolescência (como Alice, Pinóquio, Coração...). Até bem entrado o século XX, a maior parte das leituras ao alcance dessa faixa de leitores era a literatura adulta, no original ou nas adaptações que também proliferaram na época, sem dúvida para preencherem uma lacuna: a existência de livros escritos especialmente para crianças. (COELHO, 2000, p.136).

Esse resultado das reivindicações da classe burguesa reflete nas publicações de obras infantis que começam a ser feitas no Brasil, projetando um novo mercado, o editorial. E, assim, junto com ele surge a demanda da continuidade de uma tradição que, na realidade, ainda precisava ser inventada, uma vez que o país não cultivava tradição na escrita de livros especialmente para crianças.

É certo que essas mudanças não ocorreram de uma hora para outra, e em meio a importação de textos e seus valores ou desvalores, estavam as adaptações como forma de revigorar narrativas, mostrando-as quase como se fossem novas, levando-se em conta que muitas das obras adaptadas passaram a ser vistas como exclusivamente infantis. Exemplo disso, é o caso de Carlos Drummond de Andrade ("Fim", in: Boitempo e a falta que ama) e também o de Jorge Amado ( $O$ menino grapiúna) que em seus textos memorialistas 
inserem, respectivamente, duas obras britânicas: Robson Crusoé (1719), de Daniel Defoe, e Viagens de Gulliver (1726), de Joanathan Swift, obras que caíram não só no gosto das crianças inglesas, mas no de todo o mundo, sobretudo por causa de suas adaptações que conferem às obras um caráter dinâmico, formato que cada vez mais se perpetua e garante a escolha dessas leituras ainda hoje em circulação pelo mundo.

Nesse percurso, nota-se que a manifestação literária, refletida no final do século XIX, é determinada por um grupo que influenciava na formação dos valores vigentes: a burguesia. E, portanto, a literatura destinada à criança só se consolida quando um tipo específico de literatura surge com a missão de ensinar bons modos, moralizar e modelizar o sujeito-criança, com o propósito de contribuir com a boa educação dos filhos da classe burguesa. Consequentemente, nesse momento, não havia preocupação com a função estética ou com as qualidades próprias do universo literário. Diante desse quadro, em que o indivíduo é colocado como mero receptor, Gregorin Filho diz:

Educação e leitura no Brasil, do final do século XIX até o surgimento de Monteiro Lobato, viviam alicerçadas nos paradigmas vigentes, ou seja: o nacionalismo, o intelectualismo, o tradicionalismo cultural com seus modelos de cultura a serem imitados e o moralismo religioso, com as exigências de retidão de caráter, de honestidade, de solidariedade e de pureza de corpo de alma em conformidade com os preceitos cristãos. (GREGORIN FILHO, p. 16, 2011).

No entanto, a literatura infantil brasileira tem a oportunidade de construir sua própria identidade literária a partir das significativas mudanças ocorridas no final do século XX, período em que Monteiro Lobato traz à tona outras discussões que tomariam conta do novo cenário infantil, mudando-o definitivamente. Isso incluía colocar fim às chamadas "traduções galegais" a que o próprio Lobato (1944, p. 453) se refere em carta, de janeiro de 1925, ao amigo Godofredo Rangel: "Estou a examinar os contos de Grimm dados pelo Garnier. (...) Pobres crianças brasileiras! Que traduções galegais! Temos de refazer tudo isso - abrasileirar a linguagem.”

Diante desse contexto, Lobato institui um universo onde as crianças "podem morar" e rompe, claramente, com a literatura europeia que, inclusive, fazia vista grossa à crítica social inserida nas fábulas, pois acreditava-se que tal gênero organizava valores 
negativos e, portanto, não poderiam ser considerados modelos literários de educação para o contexto social europeu da época.

Em outras palavras, o Brasil corta o cordão umbilical com os modelos de cultura imitados e os padrões das cartilhas de bom cidadão que os meninos deveriam seguir. Monteiro Lobato, indiscutivelmente, foi o precursor de um novo fazer literário infantil, em que havia, também, lugar para as ilustrações como linguagem visual significativa. O autor, com seus textos, devolveu às crianças mais que um lugar de identidade onde elas pudessem pensar, deu a elas um espaço onde poderiam ser ouvidas. É nesse sentido que Gregorin Filho afirma que:

Com o surgimento de Monteiro Lobato e sua proposta inovadora de literatura infantil, a criança passa a ter vontade e voz, ainda que vindas da boca de uma simples boneca de pano: Emília. O que importa é que a contestação e a irreverência infantis sem barreiras começam a ser lidas e vistas por meio dos textos e ilustrações das personagens do Sítio do Picapau Amarelo.

Lobato apresenta características até então não exploradas no universo literário para crianças: apelo a teorias evolucionistas para explicar o destino da sociedade; onipresença da realidade brasileira; olhar empresarial e patronal; preocupação com problemas sociais; soluções idealistas e liberais para os problemas sociais; tentativa de despertar no leitor uma flexibilidade face ao modo habitual de ver o mundo; relativismo de valores; questionamento do etnocentrismo e um outro ponto importante: a religião, como resultado da miséria e da ignorância. (GREGORIN FILHO, 2011, p. 16-17).

A partir das mudanças ocorridas, consequentemente, os decretos educacionais foram se transformando à medida que cada década rapidamente ia passando. Com isso, é possível pensar que o século XX foi um momento, neste aspecto, de intenso envolvimento na formação da criança. Afinal, nesse período, a Educação sofreu processos e reestruturações sociais capazes de refletir mudanças no seu próprio discurso, remetendo a pensar, de acordo com Bakhtin (1981, p. 43) que: "Cada época e cada grupo social tem seu repertório de formas de discursos na comunicação social-ideológica".

Todavia, mesmo diante de tantas mudanças, ao longo dos tempos, é mister observar que quem ainda detém a palavra - discurso educacional - é a burguesia e são os valores desta classe que continuam ditando as regras, embora de modo não marcado, mas 
engendrado por sutilezas que fazem crer o seu protagonismo em detrimento da arte; da literatura infantil e sua maneira atualizada de valorar os novos textos.

Decerto, em princípio, a condição da literatura infantil implica os modos de ser entendida por meio de seus textos e consequentemente pelo fascínio que ela exerce sobre o público que cativa. Nesse caso, há de se considerar a vigente manutenção do seu papel articulador e, sobretudo, manipulador, não muito diferente do contexto em que surgiu como doutrinária, pueril e moralizante. De acordo com Arroyo (2011) essa dita literatura se apresente séculos recuados, ou seja, antes mesmo de se firmar em fins do século XVII, período que assinala também o surgimento do livro para crianças, Orbis sensualium pictus $^{11}$, escrito por Comenius, e é a partir desse período que se passa a ter noções mais concretas sobre a literatura infantil como categoria literária. Assim, segundo Arroyo (2011, p.13):

A literatura infantil como categoria literária, de acordo com a conceituação adotada atualmente pelos maiores especialistas no assunto, quer europeus ou norte-americanos, e principalmente europeus, é muito recente, o que não exclui a floração de uma série de problemas [...]. Data ela dos fins do século XVII, quando Fénelon, com o seu Traité de l'éducation des filles [tratado sobre a educação das meninas], lançou novos princípios de educação. $\mathrm{O}$ autor procurava diversificar as então tradicionais leituras que se entregavam às crianças, ou seja, os livros piedosos de vidas de santos ou de personagens das sagradas escrituras. Encarregado da educação do Duque de Borgonha, Fénelon deu como leitura ao menino livros profanos, inspirados na mitologia, nos fatos lendários da Antiguidade ou na tradição popular. Pela primeira vez, então, como assinala Marie-Thérèse Latzarus, uma criança tinha entre as mãos livros escritos para ela mesma. (ARROYO, 2011, p. 13).

Diante desse contexto, interessa observar a literatura a partir das narrativas destinadas às crianças e jovens, considerando, para tanto, que essa literatura ainda esteja atravessada pelo questionamento de Carmen Bravo-Villasante, cujo alerta recai sobre o fato de se chamar de literatura infantil às estórias, lições de moral e comportamento, de

\footnotetext{
${ }^{11}$ Orbis sensualium pictus (O mundo em imagens) - do professor tcheco e intelectual Jan Amos Comenius foi publicado em 1657. Trata-se do primeiro texto totalmente ilustrado para crianças, espécie de enciclopédia com xilogravuras destinada à alfabetização e toda escrita, inicialmente, em latim e alemão. Esse trabalho se destaca como uma obra bastante significativa para a História da Pedagogia.
} 
educação, de que se tem registros tanto na Antiguidade, quanto na Idade Média (Arroyo, 2011).

Dito isso, há de se considerar, ainda, o deslocamento do campo didático para o campo literário que o século XIX vai consolidar a partir, principalmente, da primeira fase da Era Romântica em que se vê um acentuado crescimento no número de autores e de obras que marcam a origem e a evolução da Literatura, das ideias e dos novos valores que, hoje, são reconhecidos como tradição. O século XIX ficou conhecido como o século de ouro do romance e da novela, marcado pelo encontro de diferentes tendências e correntes literárias capazes de misturar o culto e o popular. Desse encontro nasce, então, o gênero romance como narrativa que reflete a sociedade do seu tempo, tornando-se a forma mais importante desse período e herança para o século XX.

Atravessada nesse movimento de mudanças ou transformações (espaciais e temporais) está também a evolução social e sua mentalidade, que modifica as maneiras de pensar o mundo, alterando a vida no seu cotidiano e nas suas práticas, o que por certo reflete uma nova representação desse mundo no contexto da Literatura e das Artes.

Diante do processo de renovação de valores estão a criança e o jovem como seres carentes do olhar para sua formação humanística, cívica, espiritual, ética e intelectual. Assim, os novos conceitos que surgem como o de vida, de educação e de cultura apontam novos caminhos para os também novos procedimentos, tanto nas áreas pedagógica quanto literária. É o momento em que a criança e o jovem ganham certo reconhecimento no processo social e no contexto humano e suas valoras.

Decerto esse processo não se fez como num passe de mágica, e a transformação cultural que refletiu na descoberta da infância e da adolescência se mostram por etapas. Nesse tocante, Coelho diz que:

A criança começa por ser encarada como um adulto em miniatura, cujo período infantil deveria ser encurtado o mais depressa possível para que ela pudesse superá-lo e alcançar o estado de adulto, ideal. A descoberta da qualidade específica do ser criança ou ser adolescente (como estados biológicos, psicológicos e valiosos no desenvolvimento do ser) será feita no século XX. O idealismo romântico, entretanto, criou o mito da infância (como o da idade de ouro do ser humano) e o da adolescência (como o da pureza e sensibilidade instintivas que o mundo adulto corromperia ou decepcionaria). (COELHO, 2010, p. 148). 
E eis que, junto com essa descoberta da qualidade específica do ser criança ou ser adolescente surge simultaneamente a preocupação com uma literatura capaz de dialogar com esses sujeitos, servindo-lhes não só de de leitura para informação e conhecimento, mas sobretudo para a formação enquanto indivíduos num mundo conectado. 


\section{TRADIÇÃO E REPRESENTAÇÃO NA LITERATURA INFANTIL}

“[...] Um olhar diferente para a revisão da importância estética, política e principalmente cultural da literatura para jovens também pressupõe outra postura para a literatura, não apenas como um bloco de textos circunscritos numa rígida e imutável linha temporal, mas numa concepção mais ampla e dinâmica, em que se volta a atenção para as características que inserem um determinado texto no âmbito de outras produções artísticas com a linguagem; desse modo, é importante que se volte a atenção para a literatura como representação simbólico-imaginária das relações sociais." (GREGORIN FILHO, 2015, p. 169).

O conto de fada e sua fabulação constroem um momento fundamental no processo de organização da experiência de vida da criança. As narrativas inscritas nessa forma tratam de aspectos importantes que permeiam a vida do infante e seu desenvolvimento enquanto "ser" no mundo. Esse ato de contar retroalimentando-se, em determinados contextos, da sabedoria popular e sendo transmitido aos filhos pela mãe ou ama, por meio da oralidade, formou um patrimônio de cultura - experiências humanas; desenvolvimento e questões existenciais que atravessaram o tempo e se reorganizaram em outros espaços do saber-conhecer:

Assim, os contos de fadas acabam por reforçar a autoimagem do leitor, colaborando para seu crescimento interior e autonomia, o que justifica não apenas a popularidade que detêm até nossos dias, como também a permanência das figuras principais, convertidas, de certo modo, em símbolos de comportamentos e ideias, ultrapassando, portanto, o âmbito primeiro dentro do qual foram criados. (ZILBERMAN, 2014, p. 92).

Nos dias de hoje, no mundo onde se vive um intenso processo de transformações, é urgente que a literatura se mostre eficiente na formação da nova consciência das novas gerações que vão surgindo com suas diferentes maneiras de interação e evolução, desde a origem dos tempos primeiros. Nesse sentido é importante, de certa forma, pensar a origem da literatura infantil, atualmente conhecida como clássica, retomando seus ancestrais ou primeiro embrião de onde se teve contato com a novelística popular medieval e suas remotas raízes orientais ou indo-europeias. 
Quando se fala em livros consagrados como clássicos infantis, é quase automático pensar em contos de fada ou contos maravilhosos de autores como Perrault, irmãos Grimm, Andersen ou ainda nas fábulas de La Fontaine. Isso, na maioria das vezes, de maneira tão pontual, que se chega a ignorar o fato de que esses autores não são os verdadeiros responsáveis por essas narrativas, mas compiladores desses textos, que desde o século XVII, passando pelo XIX, interessados na literatura folclórica ou popular, recolheram tais narrativas de seus respectivos países, reunindo essa histórias anônimas, já contadas há séculos, transmitidas para diferentes gerações e registraram via escrita. Assim, organizadas em livros, receberam os nomes de seus recriadores e continuam até hoje a fascinar, além de se difundir pelo tempo e espaço.

Diante da impossibilidade de se saber a verdadeira origem dessa literatura popular, que vinda através dos tempos chega à contemporaneidade, consideram-se hipóteses a partir de documentos conservados em diferentes regiões (inscrições em pedras, em tabuinhas de argila ou vegetal, escrituras em papiro ou pergaminho, dentre outros) e também pela memória privilegiada de alguns contadores de estórias. Esses registros colaboraram para se pensar nas primeiras formas de escrita capazes de permitir que palavras ditas há milênios pudessem chegar até o século XXI. Ainda, segundo estudiosos, tais inscrições primitivas estariam ligadas a antigos rituais em que:

A palavra desde sempre impôs-se aos homens como algo de mágico como um poder misterioso que poderia tanto proteger quanto ameaçar; construir ou destruir. Daí os cantos e as fórmulas mágicas que, nos rituais dos povos primitivos, ajudariam o homem a vencer as forças que eram hostis: as da Natureza, dos animais ou dos inimigos.

São também de caráter mágico ou fantasioso as narrativas hoje conhecidas como Literatura Primordial: aquela que, embora não transcrita em material perene, atravessou séculos, preservada pela memória dos povos. Nela foi descoberto o fundo fabuloso das narrativas orientais, que se forjaram durante séculos antes de Cristo e se difundiram por todo o mundo cristão através da Tradição Oral. (COELHO, 2010, p. 6-7).

Nesse percurso está, sem dúvida, a força da palavra que, sobrevivendo ao tempo e às adversidades, prova que a comunicação entres os homens é fundamental à própria natureza humana, tanto quanto a necessidade de contar sobre suas experiências, seus conflitos. 
Com relação à origem da literatura popular infantil no ocidente, sabe-se, de acordo com Coelho (2010), que ela está presente naquelas longínquas narrativas primordiais, de origens que remontam fontes orientais bastante heterogêneas e cuja transmissão, no ocidente europeu, aconteceu durante a Idade Média, por meio da oralidade. Dessas narrativas primordiais orientais surgiram as narrativas arcaicas que findaram por se popularizar na Europa e, em seguida, em colônias americanas como o Brasil, vindo a ser chamada de literatura folclórica, que no Nordeste do Brasil é reconhecida, ainda hoje, como literatura de cordel e como folclórica, aquela através dos registros de Perrault, dos irmãos Grimm, etc.

Diante dessas duas formas de representação literária, a folclórica e a infantil, tanto em Portugal quanto no Brasil, verificou-se que as versões folclóricas de determinadas narrativas apresentam diferentes variantes, de acordo com as regiões onde se fincaram. Ao contrário, as versões infantis se reproduzem, quase sem alterações, nas muitas edições que sucedem. Nisso ocorre a flexibilidade da vida, como resultado da transmissão oral, em contraponto à imutabilidade do texto literário que a escrita determina.

Há nisso tudo, a necessidade de se rever tais narrativas sob a ótica de novas concepções de sociedades e culturas, percebendo como as narrativas do passado ganharam novos investimentos valorativos. E é pensando nisso, que se retoma o conto enquanto forma, considerando-se o conto de fada como manifestação textual significativa para a criança, ainda hoje. De acordo com Jolles:

O conto só adotou verdadeiramente o sentido de forma literária determinada no momento em que os irmãos Grimm deram a uma coletânea de narrativas o título de Kinder-und Hausmärchen (Contos para Crianças e Famílias). Assim fazendo, contentaram-se em aplicar às narrativas por eles compiladas uma palavra que já vinha sendo usada há muito tempo. Desde o século XVIII que se conheciam, efetivamente, os Feenmärchen (Contos de Fadas), os Zauber-und Geistermärchen (Contos de Magia e Fantasmagoria), Märchen und Erzählungen fur Kinder und Nichtkinder (Contos e Narrativas para Pequenos e Grandes), Sagen, Märchen und Anekdoten (Histórias, Contos e Anedotas).[...] Contudo, foi a coletânea dos irmãos Grimm que reuniu toda essa diversidade num conceito unificado e passou a ser, como tal, a base de todas as coletâneas ulteriores do século XIX [...]. (JOLLES, 1976, p. 181-182). 
Sobre os contos de fadas enquanto narrativas que constituem o vasto acervo da chamada literatura infantil clássica, Coelho, ao citar obras como Chapeuzinho Vermelho, Branca de Neve e O Pequeno Polegar, classifica-as como contos de fadas, cujas particularidades devem ser observadas com certa atenção:

Com ou sem a presença de fadas (mas sempre com o maravilhoso), seus argumentos desenvolvem-se dentro da magia feérica (reis, rainhas, príncipes, princesas, fadas, gênios, bruxas, gigantes, anões, objetos mágicos, metamorfoses, tempo e espaço fora da realidade conhecida, etc.) e têm como eixo gerador uma problemática existencial. Ou melhor, têm como núcleo problemático a realização essencial do herói ou da heroína, realização que, via de regra, está visceralmente ligada a união do homemmulher.

A efabulação básica do conto de fadas expressa os obstáculos ou provas que precisam ser vencidas, como um verdadeiro ritual iniciático, para que o herói alcance sua auto-realização existencial, seja pelo encontro de seu verdadeiro eu, seja pelo encontro da princesa que encarna o ideal a ser alcançado. (COELHO, 1991, p. 13).

Essas histórias circulavam como contos populares entre os povos de pequenos vilarejos medievais onde hoje estão Alemanha e França. Nesse tempo, os contos serviam tanto para educar as crianças (daí a razão da moral incluída em cada história), quanto para distrair ou entreter os adultos.

No mundo medieval, o maravilhoso fazia parte do cotidiano de uma sociedade que mostrava pensamentos místicos baseados na crença de que o poder divino era capaz de retratar uma realidade impossível de ser questionada. Dessa maneira, o maravilhoso se relacionava com o sobrenatural, aos milagres, ao pensamento religioso ou qualquer aspecto mágico ligado ao imaginário humano. Assim, no universo do maravilhoso, o homem encontrava justificativas para os questionamentos sobre si e alguns fenômenos para os quais não tinha respostas aceitáveis. Para Todorov, o maravilhoso:

implica estar imerso em um mundo cujas leis são totalmente diferentes das nossas; por tal motivo, os acontecimentos sobrenaturais que se produzem não são absolutamente inquietantes. Pelo contrário, na metamorfose se trata de um acontecimento chocante, impossível, mas que paradoxalmente, termina por ser possível (TODOROV, 1981, p. 89).

O maravilhoso emerge das narrativas míticas e marca forte presença nos contos de origem popular. Estes, sendo um suporte de uma tradição cultural, carregam, como 
origens, as primeiras formas de narrar que a humanidade conheceu, bem como os diversos gêneros narrativos surgidos ao longo da história. Contudo, é possível perceber que mesmo os contos tendo mudanças em seus conteúdos ou, ainda, nas figuras que fazem parte das mitologias, eles mantém uma estrutura em que os mitos podem ser facilmente identificados e distinguidos como sugere Eliade (2000, p.166): "nas figuras dos protetores, dos adversários e dos companheiros dos heróis. Estão camuflados (...), 'diminuídos', mas continuam a desempenhar a sua função."

Nesse contexto, cria-se, portanto, uma espécie de verdade que vai sendo moldada; ganhando formatos variados em função dos sentidos das coisas e suas representações no mundo. E, à medida que o tempo passa, tais representações são levadas a se reinventar em função de novos valores, novas linguagens, além de outras maneiras de identificação com os sujeitos já transformados. Outrossim, as narrativas dos contos de fada reforçam o contato da criança com a palavra - com o verbo - cujo valor é o de representar o mundo no qual ela vive, refletindo situações de conflito: medo, sofrimento, perigo, insegurança, etc.

É por meio da palavra que as coisas acontecem, assim como é por meio dela, também, que a criança passa a se identificar com a personagem da história, que sendo capaz de vencer os obstáculos consegue se reconhecer como sujeito apto a enfrentar desafios. Assim, as histórias consagradas como clássicos trazem à tona uma realidade forjada pela palavra que reconstrói, via imaginário, uma dada ordem simbólica capaz de refleti-las como arte pois:

[...] continuam falando aos homens, porque, devido à verdade geral que expressam e ao meio metafórico com que foram concretizados, podem ser continuamente atualizados. Isto é, aludir a mil outras e diferentes circunstâncias particulares com a mesma verdade com que foram expressos originalmente.

É esse o caráter fundamental da literatura (ou da arte em geral): traduzir verdades individuais, de tal maneira integradas na verdade geral $e$ abrangente, que a forma representativa escolhida, mesmo perdendo, com o tempo, o motivo particular que a gerou, continua falando aos homens por outros motivos, também verdadeiros, no momento em que surgem. (COELHO, 2000, p. 44-45).

Isso posto, é considerando a força, que atravessa o tempo, de tais narrativas ou contos primordiais, não só nos livros (suportes impressos), mas em suportes textuais 
variados, que se observa uma dada permanência de suas verdades refletidas na contemporaneidade. Um exemplo disso, principalmente porque projeta a maneira reveladora dos valores das narrativas de outros tempos no tempo de agora, além de apresentar-se a partir das matrizes oral e escrita que utiliza como estratégias para captar, pela familiaridade, o seu leitor ou espectador inscritos nesse texto é Shrek, um filme de animação computadorizada, norte-americano de 2001, dos gêneros fantasia e comédia dirigido por Andrew Adamson \& Vicky Jenson, produzido pela DreamWorks e lançado pela DreamWorks Pictures.

Assim, a captação imediata já se dá na abertura da animação, como é possível ver (figuras 10 e 11), a seguir, em que a tela ${ }^{12}$ é tomada pela imagem de um livro (que ocupa todos os espaços), cujas características e formato da capa revelam tratar-se de uma história de tempos passados e que será contada, portanto, naqueles moldes, ou seja, convidando o espectador quase a sentar-se em torno da lareira para que a magia do contar possa entrar em ação e cumprir aquilo a que se destinava: fascinar o ouvinte.

E eis que, quadro a quadro na tela ou vídeo, tem-se a revelação dada não só pela visualidade do objeto livro, apresentado como protagonista, mas principalmente pela oralidade que pelo modo como é pronunciada (criando efeito do tom da voz que conta) faz parecer tratar-se de uma narrativa de contos de fada ou maravilhoso, denunciada pela marca "Era uma vez", cujo caráter finda por confirmar o contrato estabelecido com o espectador, agora, construído como o receptor desse texto que vai desvelando-se à sua frente e fazendoo crer tratar-se realmente de uma narrativa primordial organizada nos moldes das histórias clássicas consagradas que passaram a circular entre os povos de um determinado tempo e espaço.

$\mathrm{Na}$ identificação dessas narrativas, observam-se estruturas recorrentes, considerando-se tais estruturas a partir dos trabalhos de Vladimir Propp (especialista da literatura popular russa do início do século) sobre a organização narrativa do conto popular, em que o autor demonstrou, a partir da análise dos componentes básicos do enredo dos contos populares, que estes se constituem invariavelmente em torno de um núcleo simples, ou seja, o herói sofre um dano ou tem uma carência e serão as tentativas de recuperação do dano ou de superação da carência que vão organizar o corpo da narrativa. A relevância do

\footnotetext{
${ }^{12}$ Fonte das imagens de abertura do filme Shrek https://www.youtube.com/watch?v=5Dj34oHDSds
} 
fundamento sobre a narratividade dado por Vladimir Propp em A morfologia do conto maravilhoso é descrita por Bertrand da seguinte maneira:

Propp estabelece, como condição prévia, o conhecimento efetivo do objeto "conto" em si mesmo, a análise de sua morfologia, isto é, de suas regularidades e variações formais: trata-se de estabelecer a constância dos elementos (personagens e ações) e das relações (encadeamento das ações) que constitui a forma do conto popular ou, segundo seus próprios termos, de fazer a 'descrição dos contos segundo suas partes constitutivas e as relações dessas partes entre si e com o conjunto. (BERTRAND, 2003, p. 270).

Há, portanto, inscrito nesse contexto a permanência ou força da literatura arcaica ou das formas simples (Jolles, 1976): fábula, apólogo, parábola, alegoria, mito, lenda, saga, conto maravilhoso, conto de fada, conto exemplar, conto jocoso etc., que continuam a ser, de algum modo, revigoradas para outros sujeitos, noutros tempos e espaços.

Além disso, as transformações por que passaram essas formas se justificam pelo fato de tais narrativas, que surgiram anonimamente, atravessarem os tempos, desde a Antiguidade, passando a figurar do modo como as conhecemos nos dias de hoje, ou seja, como tradição popular ou mesmo clássicos infantis consagrados, uma vez que:

Os clássicos são aqueles livros que chegaram até nós trazendo consigo as marcas das leituras que precederam a nossa e atrás de si os traços que deixaram na cultura ou nas culturas que atravessaram (ou simplesmente na linguagem ou nos costumes). (CALVINO, 2013, p.11).

Figura 10 - Livro fechado: conto de fada

Figura 11 - Livro aberto: Era uma vez

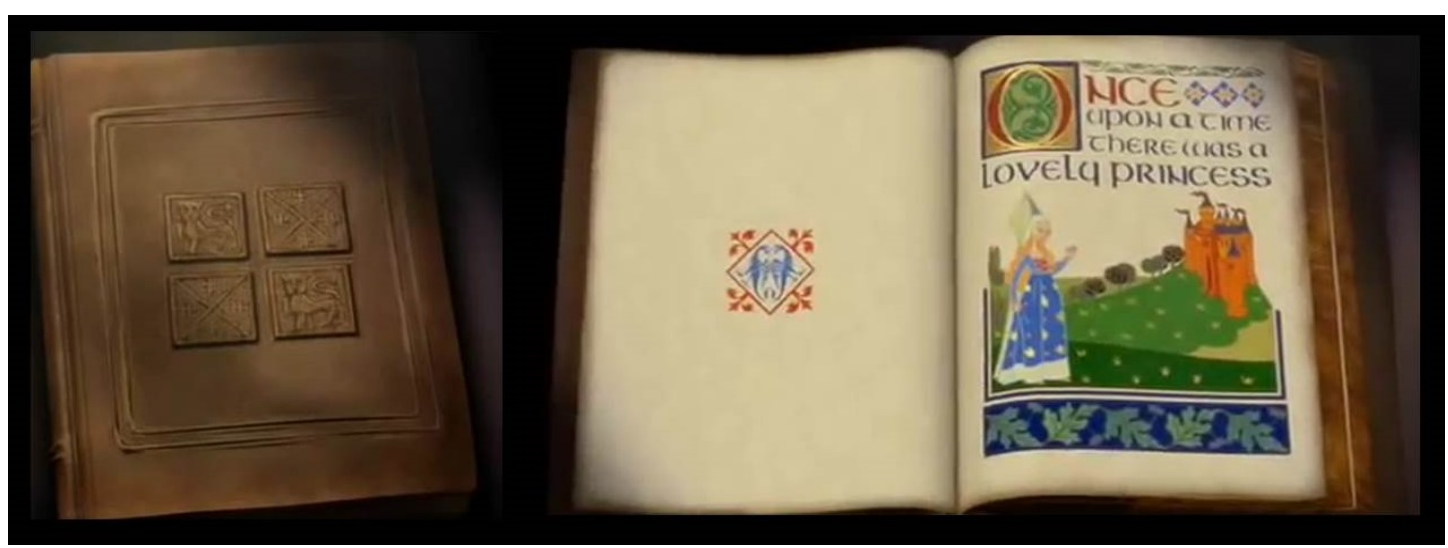


Nota-se, portanto, nas imagens da abertura de Shrek (figuras 12, 13, 14 e 15) a presença de um dado cânone das narrativas próprias dos contos de fadas em que o conflito é dado a ver por meio de alguma maldição envolvendo uma bela princesa (princesa Fiona) que, para se livrar de tal, deve ser salva por um herói (ogro Shrek), um belo príncipe, capaz de vencer as provas impostas a ele e resgatar a dama desfazendo o feitiço, que a persegue, com o "beijo de amor verdadeiro". Ação que fará dele, após vencer as provas impostas, o herói eleito a receber o maior de todos os prêmios: casar-se com a princesa e viver feliz para sempre. No caso, especificamente de Shrek, que se identifica pelas características físicas de ogro, sem a beleza e nem os atributos de um príncipe, o que faz dele um herói, nesse percurso, é a ação. Seguindo o mesmo padrão de desconstrução, a princesa Fiona é revelada como forte e independente, portanto, rompendo com a fragilidade prescrita na figura feminina da princesa que precisa ser salva.

Campbell (1995), após estabelecer relações entre narrativas míticas heroicas, observando diferentes culturas e épocas, sistematiza algumas etapas que mostram que as narrativas podem se diferenciar quanto ao contexto, a ação e o caráter estético, mas findam por resguardar uma estrutura próxima, sendo estas reconhecíveis nas diversas narrativas com as quais deparamos, assim como nas vivências cotidianas dos seres humanos. $\mathrm{O}$ autor argumenta a partir da relação que tece entre o mito e os rituais de passagem até chegar a definição de um percurso padrão da aventura do herói, dividido em três fases: separação, iniciação e retorno. Assim, para Campbell:

O herói mitológico, saindo de sua cabana ou castelo cotidianos, é atraído, levado ou se dirige voluntariamente para o limiar da aventura. Ali, encontra uma presença sombria que guarda a passagem. O herói pode derrotar essa força, assim como pode fazer um acordo com ela, e penetrar com vida no reino das trevas (batalha com o irmão, batalha com o dragão; oferenda, encantamento); pode, da mesma maneira, ser morto pelo oponente e descer morto (desmembramento, crucifixão). Além do limiar, então, o herói inicia uma jornada por um mundo de forças desconhecidas e, não obstante, estranhamente íntimas, algumas das quais o ameaçam fortemente (provas), ao passo que outras lhe oferecem uma ajuda mágica (auxiliares). Quando chega ao nadir da jornada mitológica, o herói passa pela suprema provação e obtém sua recompensa. Seu triunfo pode ser representado pela união sexual com a deusa-mãe (casamento sagrado), pelo reconhecimento por parte do pai-criador (sintonia com o pai), pela sua própria divinização (apoteose) ou, mais uma vez se as forças se tiverem mantido hostis a ele -, pelo roubo, por parte do herói, da bênção 
que ele foi buscar (rapto da noiva, roubo do fogo); intrinsecamente, tratase de uma expansão da consciência e, por conseguinte, do ser (iluminação, transfiguração, libertação). O trabalho final é o do retorno. Se as forças abençoaram o herói, ele agora retorna sob sua proteção (emissário); se não for esse o caso, ele empreende uma fuga e é perseguido (fuga de transformação, fuga de obstáculos). No limiar de retorno, as forças transcendentais devem ficar para trás; o herói reemerge do reino do terror (retorno, ressurreição). A bênção que ele traz consigo restaura o mundo (elixir) (CAMPBELL, 1995, pp.177-178).

Figura 12 - Conflito: maldição

Figura 13: Prova: desafio

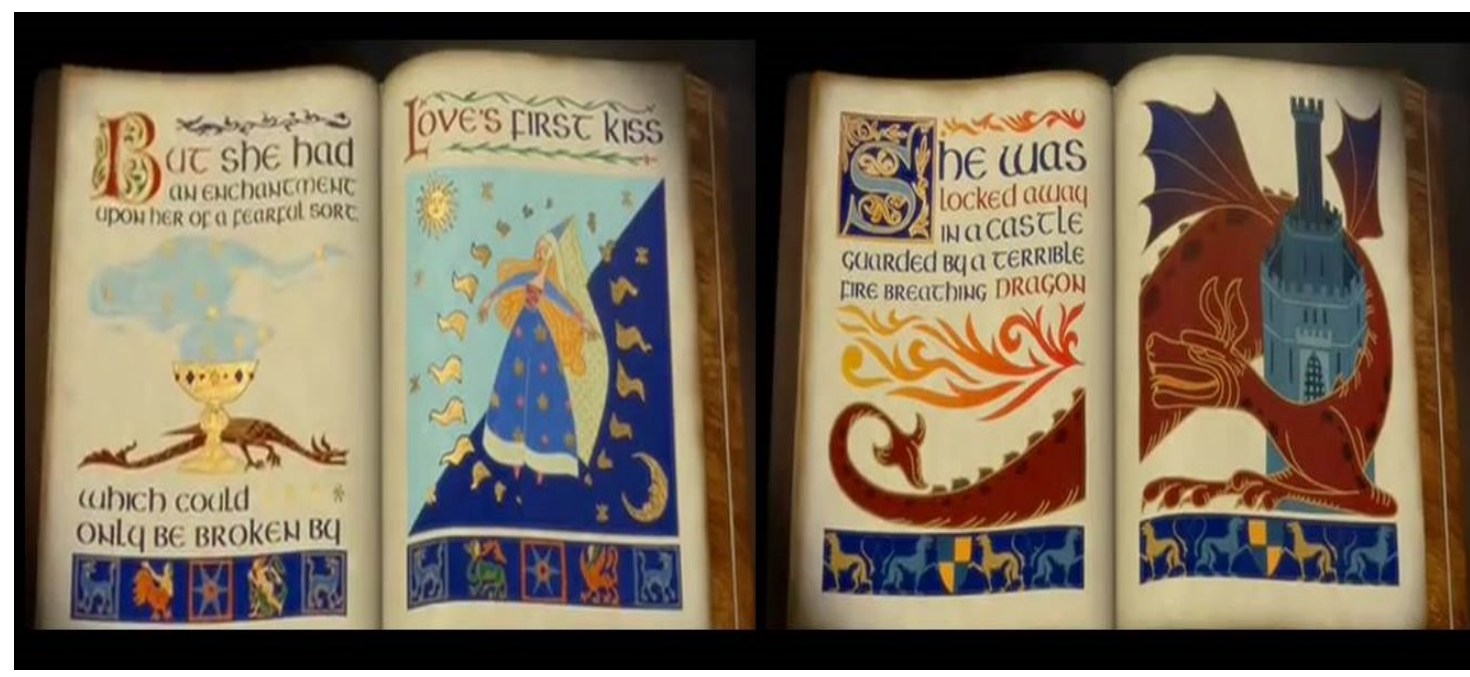

Figura 14 - Confirmação da competência

Figura 15 - Prêmio: o amor verdadeiro

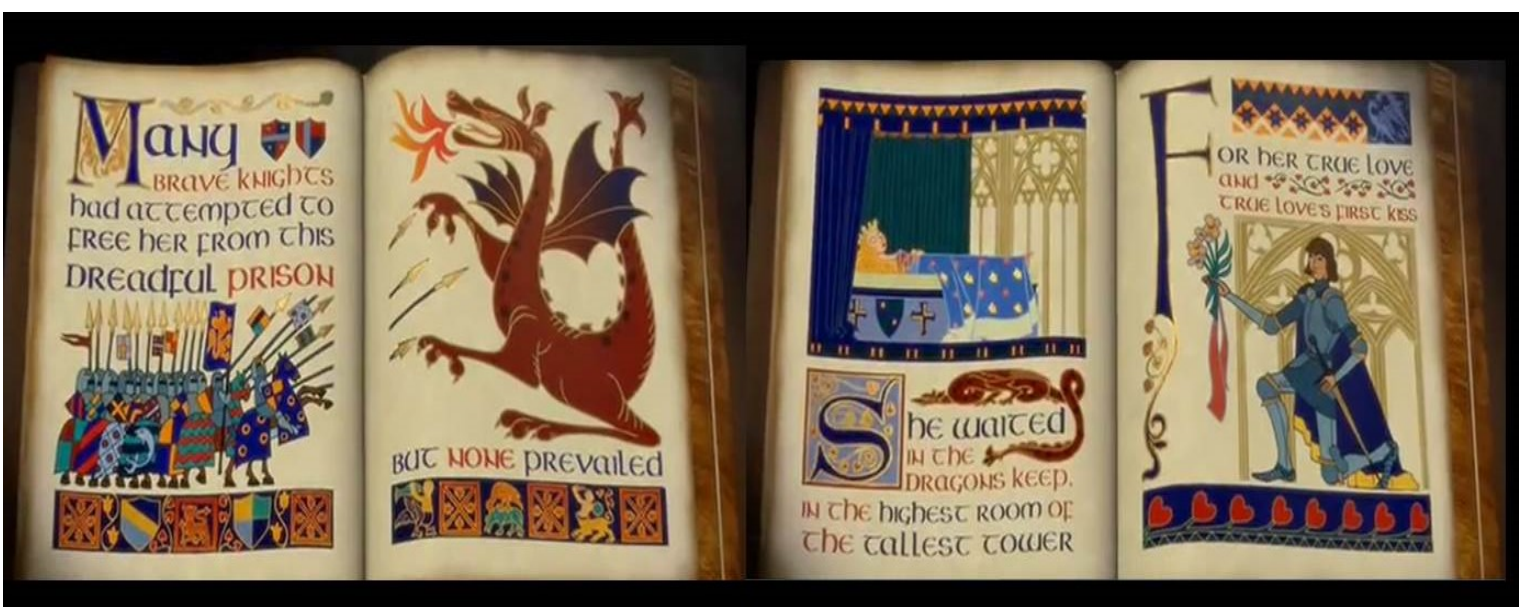

Contudo, como é possível observar, esse texto não intenciona contar a história tal qual ela se fez conhecida pelo imaginário de vários povos, muito ao contrário pretende romper com a tradição fazendo surgir um novo arranjo a partir da matriz ou dos elementos 
já conhecidos. Para tal, instaura nessa sequência narrativa audiovisual, a ruptura anunciada literalmente em dois momentos que se sucedem ao "contar" do audiovisual (figura 16): no primeiro (parte superior da imagem) - Shrek, ogro e narrador, rasga desdenhosamente a página seguinte do livro, antes do fim da história e do "felizes para sempre"; no segundo (parte inferior da imagem) o ogro atira a página rasgada do livro no vaso sanitário e "aciona a descarga", e é nesse momento exatamente que se vê como tal fato anuncia, a partir da ruptura da tradição ou cânone, uma nova história ou forma de recontar.

A ruptura instaurada pela descarga coloca passado e presente em confronto. Isso se dá no momento do estranhamento da cena que rompe bruscamente com o modelo de sociedade concebida para refletir na nova maneira de narrar dos clássicos, agora apresentada por meio do jocoso ou mesmo da dessacralização dos elementos já conhecidos daquelas histórias para compor um novo momento do conto de fada anunciado. É quando, notadamente, vê-se outro tempo (o de agora, com o qual o espectador se identifica imediatamente) apresentado por meio de uma linguagem coloquial com uso de variantes gírias, provérbios populares, intertextos com outros filmes atuais, comportamentos, etc.

Além disso, a Idade Média no audiovisual é manifestada pelos traços da modernidade como uma espécie de observação que indica que o tempo mudou, mas as sociedades ainda mantêm determinados padrões de comportamentos como o gosto pelo belo (aparência x essência), a manutenção de classes sociais em ascensão (dominante $x$ dominado), as diferenças sociais (riqueza x pobreza), a luta pelo poder (prêmio x castigo).

Pode-se mesmo pensar que nesse tipo de texto já está inscrito ou prescrito um novo contrato com o também novo espectador, em tese leitor de contos de fadas e de narrativas maravilhosas empolgantes que vai se deparar, no decorrer da animação, com elementos já conhecidos, pois o arranjo do texto audiovisual se retroalimenta com as personagens das narrativas clássicas infantis primordiais como Cinderela, Branca de Neve, Os três Porquinhos, Pinóquio, etc., ao mesmo tempo em que as atualiza em um novo contexto: o contemporâneo.

Dessa feita, as personagens permeiam os espaços físicos (floresta, castelo, etc.) e os espaços imaginários quando remetem o sujeito a rememorá-los em suas histórias consagradas pela tradição, embora vez por outra apareçam deslocadas de seus contextos de origem e colocadas em situações que correspondem aos valores sociais vigentes, 
corroborando a ideia de ruptura ou subversão como características latentes no novo modo de contar da literatura.

Figura 16 - Shrek: momentos de ruptura

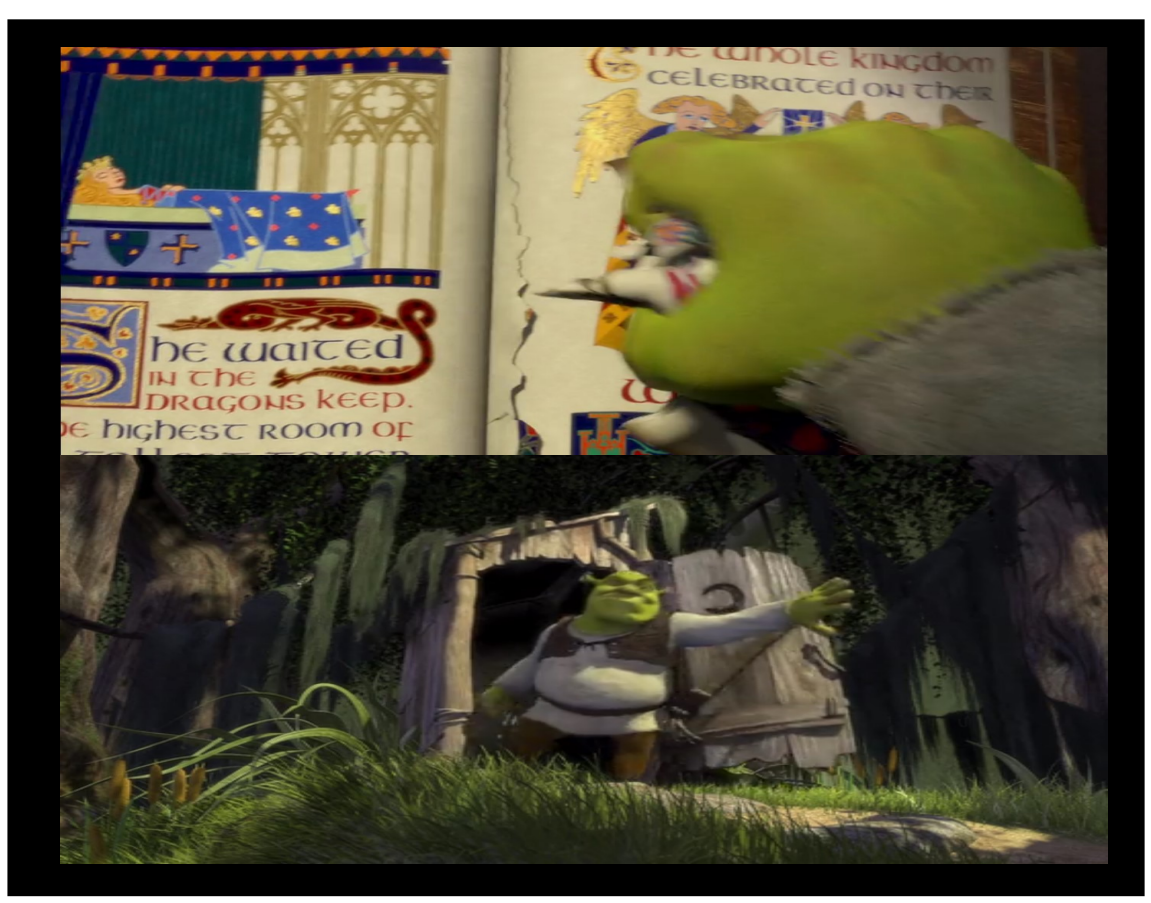

É ainda a partir desses elementos que um outro ponto de vista sobre os contos de fada e dos contos maravilhosos passam a ser apresentado sem que, com isso, sejam ignorados os elementos fundamentais ao conto clássico como, por exemplo, as personagens e o espaço narrativo das ações, fundamentais para o confronto estabelecido entre valores que fundem tempos e espaços diferentes ao instituir a crítica à ética, à moral e à estética do belo, sobretudo por meio do intertexto, do interdiscurso, da paródia e da ironia como recursos de criação e efeitos de sentido.

Não obstante, todo esse processo de criação e desenvolvimento do projeto fílmico se constitui em uma nova mensagem com base em dados já conhecidos, o que faz pensar que esta maneira de redefinir o texto esteja na esteira do método de recodificação que envolve uma situação nova correspondente a uma outra formulação em que de acordo com Plaza \& Tavares: 
Esta formulação parte sempre de algo codificado, de que deriva uma nova criação como uma criação de segundo grau. Trabalha-se a partir de um conjunto finito dos signos da história, os quais se dispõem como matériaprima para o desenvolvimento do processo criativo. Incorpora-se a ideia de representação da representação. Este método pode envolver várias operações: citação, imitação, plágio, paródia, glosa (comentários), estilização, tradução, etc. (PLAZA \& TAVARES, 1998, p. 115).

Com efeito, como se viu, a predominância de diálogos existentes entre as obras do presente com as do passado permite atestar a importância das narrativas primordiais, embora considerando o lugar e o modo de ver de cada uma e como elas se reconstroem ou são atualizadas capazes de interagir com o seu novo público. Questão que será abordada no próximo capítulo, sobretudo a partir das análises das obras (suportes impressos).

Nessa perspectiva, pretende-se, a partir de um estudo comparatista de contos clássicos infantis consagrados - mostrar em que medida a atualização de narrativas específicas que surgem, a partir do século XVII, recriam ou reorganizam as histórias de outros tempos fazendo ser e parecer um novo texto ou novo arranjo pelo modo como reforçam o caráter de transcriação de uma literatura que precisa estar cada vez mais próxima do seu leitor, sobretudo pelas questões temáticas importantes inscritas naqueles textos e que são retomadas no espaço do agora. O termo transcriação, utilizado nesse trabalho remete, de certa maneira, à concepção organizada por Haroldo de Campos:

O transcriador, para muito além de nos proporcionar o texto traduzido, visa a transformar o passado em algo novo, seguindo a dica de Ezra Pound (make it new). O poeta reivindica para suas transcriações o estatuto de um novo original (...), ao dissertar sobre suas traduções de Dante: Sua [da tradução] mira é produzir um texto isomórfico em relação à matriz dantesca, um texto que, por seu turno ambicione afirmar-se como um original autônomo, par droit de conquête. (CAMPOS, 1998, p.67).

No entanto, aqui, tal termo está diretamente ligado ao texto literário infantil ou mesmo ao juvenil atualizados, isso porque acredita-se que os novos arranjos que predominam na estética da sua expressão e no conteúdo dos textos contemporâneos privilegiam um modo que faz parecer ser diferente ou mesmo original, mostrando-se por meio de uma nova vestimenta que organiza a ação do texto no momento de sua representação dado o empenho por parte do destinador (escritor) em função de um destinatário (leitor) ainda em trânsito com os valores que circulam. 
Nessa relação, Gregorin Filho (2017), discutindo sobre a importância da escolha de obras literárias para jovens, retoma questões importantes no que tange à atualização de textos destinados a esse público leitor, que deve se sentir inserido nas obras porque capaz de reconhecer e acessar os valores com os quais transita e, ao mesmo tempo, porque pode questionar os valores de sua própria cultura. Considerando-se, ainda, que a literatura se configura como um importante meio para a compreensão de relações culturais e de conflitos sociais:

Assim sendo, a literatura voltada para o público juvenil, promovendo o conhecimento do indivíduo envolvido na sua frágil condição humana, instaura diálogos com outras artes e formas de produção do conhecimento, pois a literatura é constantemente construída pelas relações dialógicas que mantém com variados discursos e saberes, no amálgama cultural das sociedades contemporâneas e, sendo assim, materializada na especificidade de cada língua. [...] Além disso, deve-se compreender a atividade da leitura como um diálogo entre leitor e texto em contextos diferentes e entender a produção textual, principalmente a literária, como um ato interdiscursivo e intertextual e, portanto, não dissociado da vivência cotidiana dos jovens. (GREGORIN FILHO, 2017, p.78).

Diante disso, é importante compreender a literatura como um fenômeno de linguagem resultante de uma experiência existencial-social-cultural, pois o texto literário propõe, de certa forma ao seu leitor, a vivência ou experimentação numa determinada cultura de um grupo social específico, sendo essa capaz de traduzir várias e diferentes relações a partir de um fazer estético que está também ligado ao momento histórico dessa sociedade refletida nos textos e com a qual procura estreitar diálogo. 


\title{
III REPRESENTAÇÃO SOCIAL PELA LITERATURA
}

"Percebemos aqui que as criancinhas,

Principalmente as menininhas

Lindas, boas, engraçadinhas,

Fazem mal de escutar a todos que se acercam,

E que de modo algum estranha alguém,

Se um lobo mal então as coma, e bem.

Digo lobo, lobo em geral,

Pois há lobo que é cordial,

Mansinho, familiar e até civilizado,

Que, gentil, bom, bem-educado,

Persegue as donzelas mais puras,

Até à sua casa, até à alcova escura;

Quem não sabe, infeliz, que esses lobos melosos,

Dos lobos todos são os bem mais perigosos?"

(PERRAULT, 2004, p. 75).

\begin{abstract}
"Os contos populares transmitidos oralmente, como documentos históricos, sugerem mudanças de mentalidades, como afirma Robert Danton, para quem, há subjacente ao fantástico um substrato de realismo social. Essas narrativas revelam formas de o homem relacionar-se com a natureza, representações de mundo que constrói, esquemas nocionais bastante diversos dos que possuímos; desvendam em sua tessitura relações humanas muito complexas que se modificam social e historicamente. (CUNHA, 2008. p. 54-55).
\end{abstract}

\subsection{Chapeuzinho Amarelo: uma antropofagia anunciada}

É com as observações organizadas até aqui que se toma como obra instigante, para as análises que seguem, o texto verbo-visual Chapeuzinho Amarelo (1997), de Chico Buarque de Holanda, ilustrado por Ziraldo ${ }^{13}$ e publicado pela Editora José Olympio, com o objetivo de verificar como essa obra faz para construir deslocamentos e intersecções importantes no que diz respeito ao reconhecimento de uma literatura infantil brasileira

${ }^{13} \mathrm{O}$ trabalho de Ziraldo como escritor e ilustrador de livros infantis e juvenis é mundialmente conhecido. Autor de obras como A turma do Pererê, Flicts e O Menino Maluquinho (dentre tantas), produziu, em 1997, as ilustrações para Chapeuzinho Amarelo. Essa edição, publicada pela editora José Olympio, foi agraciada em 1998 com o Prêmio Jabuti de ilustração da Câmara Brasileira do Livro. 
contemporânea, bem como perceber o modo como se organiza para dizer o que diz, garantindo, dessa forma, uma dada atualização da narrativa de outrora. Essas relações, implicadas no texto de Chico Buarque e Ziraldo, remetem o leitor contemporâneo a um passado, não tão distante, ao mesmo tempo em que o inscrevem em um contexto passível de diálogos com valores ou desvalores de um novo século, no qual a consolidação de papéis sociais ainda está em trânsito.

A título de contextualização, é importante citar que Chico Buarque publicou Chapeuzinho Amarelo pela primeira vez em 1979, tendo como ilustradora a designer gráfica Donatella Berlendis (figura 17). O trabalho foi realizado pela Berlendis \& Vertecchia Editores que continuou a publicação até a sua $6^{a}$ edição. Nesse sentido, a menção à edição de 1979 é significativa na medida em que se deseja analisar a edição de 1997, ilustrada por Ziraldo. De qualquer forma, não se pode ignorar que cada uma dessas edições se constitui pela diferença dos traços dados pelas escolhas nos processos de ilustração o que, consequentemente, faz ver a articulação de dois textos distintos, pois ainda que o dito pelo verbal seja igual em ambos é a relação de justa medida estabelecida entre as linguagens verbal e visual que determina as diferentes formas de significações que os textos organizam e, portanto, suas maneiras diferentes de colocar o leitor a perceber suas histórias.

Figura 17 - Chapeuzinho Amarelo: primeira capa

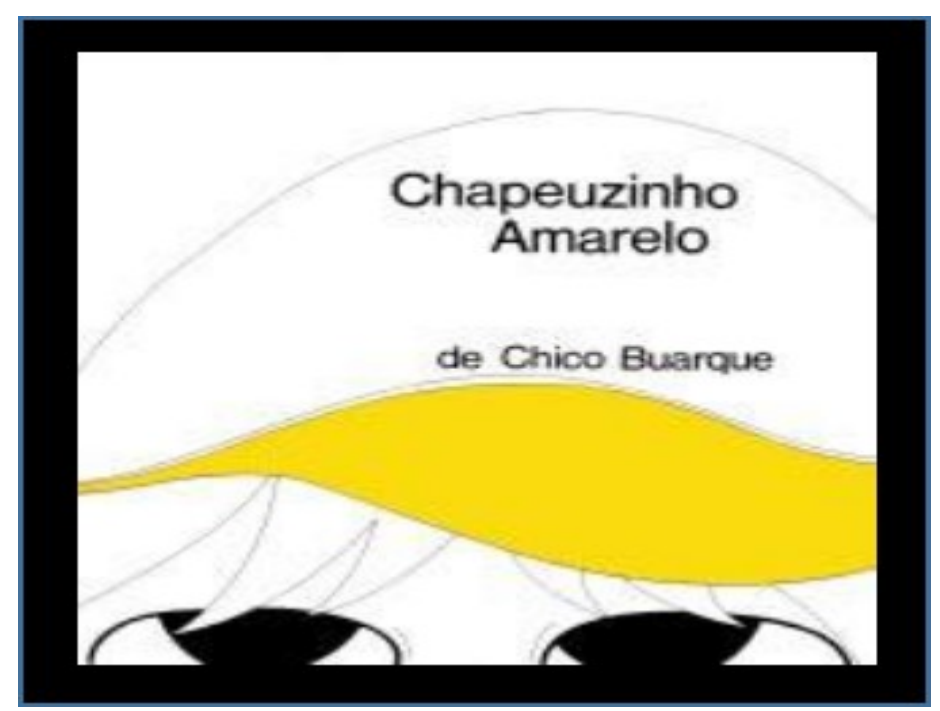

Fonte: Buarque, Berlendis (1979) 
Decerto, pensar as formas de articulação de linguagem nos textos é um grande motivador para tornar visíveis as organizações de sentido propostas em cada obra, sobretudo, considerando uma dada significação global ou unidade de sentido, capaz de dar conta do que o texto diz ou de como ele faz para dizer. Sendo assim, é a apresentação (mecanismos de manifestação verbal) do conteúdo de Chico Buarque aliado à explosão cromática (mecanismos de manifestação visual) de Ziraldo e não a delicadeza dos traços visuais de Berlendis que estarão presentes, diretamente, como fios condutores nas análises propostas e seus desdobramentos, uma vez que se observa um grau maior de plasticidade voltados especificamente para a criança na edição de 1997, cujos autores são Buarque e Ziraldo.

Para tanto, há de se considerar, ainda, o conto Chapeuzinho Vermelho, de Charles Perrault (figura 19), principalmente pelas intertextualidades marcadas em Chapeuzinho Amarelo (figura 18) como um mecanismo que esta última usa para garantir a familiaridade do leitor com aquele texto. Afinal, como se sabe, Chapeuzinho Vermelho, circula entre as obras-primas da literatura infantil que mais foram recontadas ao longo dos tempos, sendo apresentada a partir de variadas manifestações textuais. Essa obra, como tantas outras obras primordiais que circulam, ainda hoje, é fruto do material folclórico recolhido e reescrito por Charles Perrault $(1628-1703)^{14}$, no livro intitulado Les Contos de ma Mère l'Oye, de 1697 e posteriormente ilustrado por Gustave Doré numa nova edição, Les Contes de Perrault, publicada em 1862, na França do século XVII, como já fora mencionado anteriormente.

Tal referência passa a ter importância, dado o aspecto artístico da ilustração e o novo caráter plástico que acrescenta ao clássico conto Chapeuzinho Vermelho. Obra para qual se voltará o olhar na tentativa de perceber suas atualizações, portanto, a partir de Chapeuzinho Amarelo, bem como suas implicações num tempo, espaço e sujeito também modificados no período contemporâneo. Nesse percurso, finda-se por se discutir uma literatura infantil brasileira e sua identidade cultural ou, porque não dizer, uma nova forma

\footnotetext{
${ }^{14}$ No bojo das discussões sobre a verdadeira autoria dos contos de fadas, Nelly Novaes Coelho lembra que: “(...) há muito adquiriram autonomia: correram mundo sem que, na grande maioria dos casos (inclusive edições que não mencionaram autor), seu leitor ou ouvinte saiba quem os escreveu. É o destino de todas as grandes obras... dificilmente se vulgarizam sem se desprenderem da tutela de quem as realizou." (COELHO, 2010, p. 91).
} 
de ser dessa literatura. Nesse sentido, pode-se questionar sobre o que é realmente novo nesse cenário. E, para isso, Boaventura de Souza Santos traz algumas reflexões significativas:

Sabemos hoje que as identidades culturais não são rígidas nem, muito menos, imutáveis. São resultados sempre transitórios e fugazes de processos de identificação. Mesmo as identidades aparentemente mais sólidas, como a de mulher, homem, país africano, país latino-americano ou país europeu, escondem negociações de sentido, jogos de polissemia, choques de temporalidades em constante processo de transformação, responsáveis em última instância pela sucessão de configurações hermenêuticas que de época para época dão corpo e vida a tais identidades. Identidades são, pois, identificações em curso. [...]

Como se calcula, as dúvidas são acima de tudo sobre se o que presenciamos é realmente novo ou se é apenas novo o olhar com que o presenciamos. Estamos numa época em que é muito difícil ser-se linear. Porque estamos numa fase de revisão radical do paradigma epistemológico da ciência moderna, é bem possível que seja sobretudo o olhar que está a mudar. Mas, por outro lado, não parece crível que essa mudança tivesse ocorrido sem nada ter mudado no objeto do olhar, ainda que, para maior complicação, seja rebatível até que ponto tal objeto pode ser sequer pensado sem o olhar que o olha. Se o nosso olhar conceber o seu objeto como parte de um processo histórico de longa duração, é bem possível que as mudanças do presente não sejam mais que pequenos ajustamentos. Pelo contrário, a dramaticidade destes saltará facilmente aos olhos se o objeto do olhar for concebido como de curta duração. (SANTOS, 2013, p. 167-179).

Diante dessa discussão que se entrelaça no contexto de evolução ou mudanças da literatura infantil, cabe, ainda, questionar sobre o que é o contemporâneo quando se pensa a relação de atualização das narrativas de outros tempos. E tal questionamento leva à obra $O$ que é o contemporâneo? de Giorgio Agamben (2009), na qual ele situa a noção de contemporaneidade partindo de um paradoxo: "o contemporâneo é o intempestivo". Assim:

\footnotetext{
Pertence verdadeiramente ao seu tempo, é verdadeiramente contemporâneo, aquele que não coincide perfeitamente com este, nem está adequado às suas pretensões e é, portanto, nesse sentido, inatual; mas, exatamente por isso, exatamente através desse deslocamento e desse anacronismo, ele é capaz, mais do que os outros, de perceber e apreender o seu tempo. (AGAMBEN, 2009, p. 58).
}

A contemporaneidade, pressupõe, nesse sentido, uma ruptura com o próprio tempo e não uma relação de adesão com ele, o que decerto impediria um olhar diferente 
sobre os textos do passado em relação aos do presente e vice-versa. É, portanto, por meio dessa fratura que se alcançam outros textos, tempos e valores inscritos num determinado momento.

Figura 18 - Chapeuzinho Amarelo: primeira capa

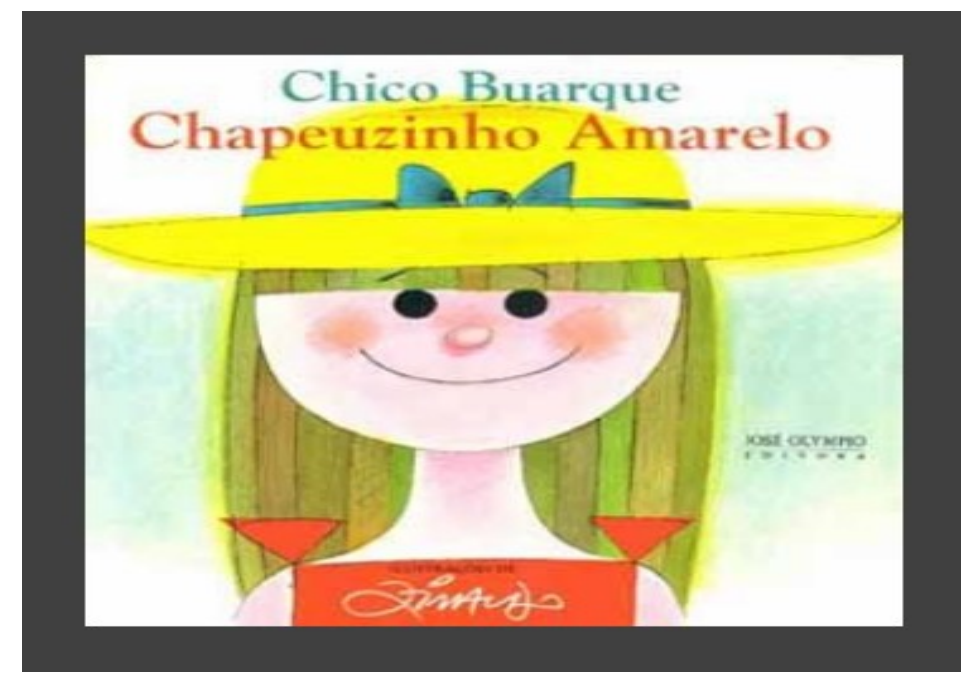

Fonte: Buarque, Ziraldo (2006)

Figura 19 - Os contos de Perrault

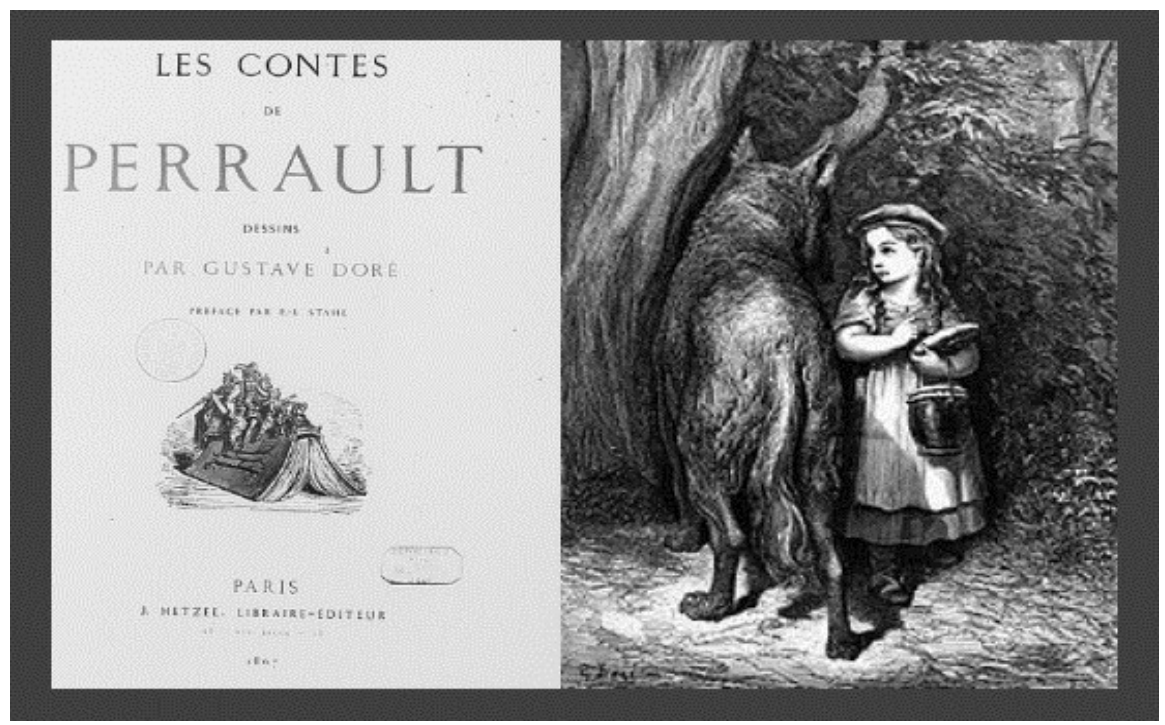

Fonte: Perrault, Doré (1862)

É comum, no século XVII, deparar com uma latente violência nos textos de Perrault e a narrativa de Chapeuzinho Vermelho não foge à regra - a história termina com o 
lobo devorando a menina e a avó. Já na versão romântica de 1812, dos irmãos Grimm, Jacob (1785-1863) e Wilhelm (1786-1859), na Alemanha do século XVIII, há uma tentativa de efeito de sentido de apagamento dessa violência e, os irmãos, embalados por novas maneiras de compreensão da criança, tentam suavizar a história, fazendo-a parecer mais humanista (ou menos violenta) pelo fato do caçador, personagem nova que inserem na trama, ao abrir a barriga do lobo, deixar que a menina e a avó saiam vivas e felizes, enquanto o lobo morre com a barriga cheia de pedras, colocadas ali pelo herói; salvador da idosa e da criança. Lembrando que Chapeuzinho, também, ajuda o caçador a colocar as pedras na barriga do lobo.

Mas é fato que, apesar da aceitação quase imediata dessa versão com final feliz, de Wilhelm e Jacob Grimm, são os próprios autores que irão reconhecer em seu terceiro volume de Kinder-und Hausmärchen, de acordo com Jolles (1976), que "as verdadeiras coletâneas de contos começaram no final do século XVII com Charles Perrault", isso de acordo, ainda, com Jolles, equivale a um salto por cima de La Fontaine que em sua obra Histoire de Psyché já havia dado uma nova configuração a uma narrativa da Antiguidade, comparável aos Kinder-und Hausmärchen, para se chegar aos Contes de ma mère l' Oye, de Perrault.

No caso da obra Chapeuzinho Amarelo, de Chico Buarque, com ilustrações de Ziraldo, as questões sobre as figuras do lobo e da menina estarão fortemente marcadas, de modo alusivo aos contos citados, no entanto com desencadeamentos atualizados, ou seja, com reflexos dos novos tempos, sociedades e valores. É importante, ainda, dizer que nesse texto sincrético tanto o verbal quanto o visual organizam os sentidos num campo grande de significações ou explosão de multilinguagem que entrelaçam outros textos, tempos, histórias, relações intersubjetivas e desembocam no agora e seus novos conflitos como é possível perceber nas análises propostas mais adiante'”.

Por texto sincrético, entende-se um texto que se define pela pluralidade de expressões que formam um todo de sentido. No nosso caso, na literatura infantil, temos duas expressões que veiculam o conteúdo, o discurso do texto ou a história: a verbal e a visual. No primeiro tomo do Dicionário de Semiótica, Greimas e Courtés (1986, p. 426) definem o termo sincretismo do seguinte modo: "Serão consideradas sincréticas as semióticas que (...) acionam várias linguagens de manifestação”. Além disso, no segundo 
tomo, ainda, do Dicionário de Semiótica, Jean-Marie Floch discorre sobre as semióticas sincréticas da seguinte forma:

As semióticas sincréticas (no sentido de semióticas-objeto, isto é, das grandes manifestações que são dadas ao sentido) são caracterizadas pela organização do texto em várias linguagens de manifestação [...]. [...] dizemos que as semióticas sincréticas constituem seu plano de expressão - com os elementos relevantes de muitas semióticas heterogêneas. Afirma-se, assim, a necessidade - e a possibilidade - de abordar esses objetos como um todo de significação e de recorrer, num primeiro momento, à análise de seu plano de conteúdo [...]. (GREIMAS \& COURTÉS, 1986, p. 217-218).

Assim, ao ato de ler Chapeuzinho Amarelo está também o de participar das interlocuções que surgem como uma espécie de convite direto a um primeiro contato com o universo de valores que o texto desvela já a partir da leitura que se inicia na primeira capa da obra (figura 18). Mesmo que isso possa parecer, a um olhar descomprometido, algo pouco revelador no que tange ao aspecto de invenção ou novidade. Afinal, não há como escapar da inevitável correspondência ou diálogo com o famoso conto Chapeuzinho Vermelho (figura 19), de Perrault ${ }^{15}$ ou mesmo com a versão dos irmãos Grimm.

Considera-se, portanto, que desde o século XVII esta história da Chapeuzinho Vermelho, assim como tantas outras desse período, permanece viva na memória da criança e do jovem, embalados pelo prazer-conhecer que a literatura proporciona, ainda que nem sempre como gênero infantil e juvenil tal qual se conhece hoje, pois os contos em sua origem eram escritos para o adulto e, por isso, vazados por conteúdos de todas as ordens como violência, incesto, sexo, etc.

É fato que essas narrativas caíram no gosto da criança, de maneira desconhecida, e foram ao longo dos tempos se transformando. E na medida em que as literaturas infantil, nesse processo, ganhou reconhecimento como tal, sofreu mudanças que

\footnotetext{
${ }^{15}$ Nessa versão, a folha de rosto em preto e branco (figura 23), ilustrada por Gustave Doré na edição de luxo, traz várias personagens montadas sobre um livro. Trata-se de personagens que figuram nas famosas histórias compiladas por Charles Perrault. Ilustração que, inclusive, remete pela referência à obra Emília no país da Gramática (1934), de Monteiro Lobato, em que se vê na capa as personagens de Lobato sobre o dorso de um rinoceronte (ver capa da obra no ANEXO F). E, claro, não se pode ignorar o título dado por Lobato e a alusão direta à Alice no País das Maravilhas (1865), de Lewis Carroll, como referência do realismo-maravilhoso (ou mágico) tão importante para a literatura infantil de Lobato - "o divisor de águas entre o Brasil de ontem e o Brasil de hoje", o responsável pela identidade atual da literatura infantil brasileira.
} 
ainda hoje estão em curso, uma vez que é possível a identificação, em suas estruturas textuais, de características veladas e outrora predominantes como as de funções de objeto regulador de comportamento; de manual de bons costumes; de cartilha ou entretenimento.

A partir desse panorama, considerando o texto e sua estética, é importante lembrar que o conto, enquanto forma, desde o seu surgimento, retomando as origens, se diferencia em conto maravilhoso e conto de fada. A história da Chapeuzinho Vermelho tem sido classificada, ao longo dos tempos, como conto de fada (com ou sem a presença da fada), mas também entendida, dentro das categorias de conto, como um conto exemplar. Sobre isso, veja-se a definição dada por Coelho:

Conto de fada: O conto de fadas é de natureza espiritual/ética/existencial. Originou-se entre os celtas, com heróis e heroínas, cujas aventuras estavam ligadas ao sobrenatural, ao mistério do além-vida e visavam a realização interior do ser humano. Daí a presença da fada, cujo nome vem do termo latino "fatum", que significa destino. (Nas raízes dos contos de fadas estão as novelas de cavalaria épico espiritualistas... ciclo do Rei Artur e seu grande cavaleiro Galaaz.) [...].

Conto exemplar: São contos de moralidades, que antigamente se contavam "ao "pé do fogo" nos longos serões do inverno europeu, que os portugueses trouxeram para a colônia brasileira e que aqui ficaram raízes. "Como diz o exemplo atigo" dizia Gil Vicente; ou os "Longos exemplos" diziael-rei D. Duarte no Leal Conselheiro; e Gonçalo Trancoso faz deles a primeira edição portuguesa em 1575. "Os exemplos ensinam a Moral sensível e popular, facilmente perceptível no enredo, de fácil fabulação, mesmo atraente e sugestiva pelo colorido do motivo." (COELHO, 2000, p. 173-181).

Tal processo, paradoxal num primeiro momento, exige a rigor, um olhar mais sensível sobre as camadas mais profundas do texto, local de percepção do modo como essas narrativas, ao serem atualizadas, passam a ser organizadas num novo arranjo, processo que pode ser entendido também como uma nova percepção de valores em trânsito.

Decerto, isso leva a considerar que mesmo que estas projeções moralizantes não tenham, de fato, desaparecido da essência das narrativas consagradas e atualizadas, elas são revestidas com novas vestimentas que vão constituir uma também nova moral para o leitor da atualidade. Dito isso, para a análise aqui proposta, é válido tomar as definições de criação e criatividade, quando se pensa no processo criativo: 
O primeiro conceito foi tomado com base na definição de Moles \& Caude (1977, p.17-32) a criação é o "processo pelo qual se provoca a existência de um novo objeto", nada mais é do que a "criação da novidade". Já o conceito de criatividade, também resgatado pelas ideias destes autores, é definido como a "faculdade da inteligência que consiste em reorganizar os elementos do campo de percepção, de um modo original e suscetível de dar lugar a operações dentro de qualquer campo fenomenológico." (1977, p.60). [...].

Se examinarmos mais detalhadamente a definição de criatividade, Moles \& Caude (1977, p. 60-5) tratam esta faculdade da inteligência como uma aptidão que possibilita ao que inventa organizar um campo de percepção projetando suas sensações em um plano de referência, modificado e combinado segundo a cultura que é inerente ao criador.

$\mathrm{O}$ criar estaria justamente relacionado com o ato de reorganizar este campo de percepção, constituindo uma nova ordem, uma nova ideia, a partir dos dados já conhecidos. (MOLES \& CAUDE 1977 apud PLAZA \& TAVARES, 1998, p. 67-68).

Nessa perspectiva de reorganização do campo perceptivo e em busca do elemento novo a partir do já existente, vê-se, na obra de Chico Buarque e Ziraldo, que o arranjo do verbo-visual é posto a convidar o leitor a se aproximar, ficar "cara a cara" com a alteridade projetada na imagem, cujo caráter simula a criança ou a menina (figura 18). Este aproximar reforça, ainda, um contrato de veridicção e remete, quase que instantaneamente, o leitor a reconhecer o consagrado clássico infantil Chapeuzinho Vermelho, pelos traços intertextuais inscritos não só pelo verbal denunciativo, mas também pelas formas de apreensão da visualidade em que o cromatismo do vermelho, em tom escuro, no título Chapeuzinho Amarelo e no vestido da menina em questão corroboram traços de certo diálogo entre as obras postas a ver. Sobre isso, Gregorin Filho afirma que:

A existência desse relacionamento intertextual - o diálogo entre textos cria a possibilidade de entender a literatura infantil como sendo aquela que contém em sua manifestação textual espaços, personagens e tempos constantes de outros textos, não somente no que se refere à pararrealidade conseguida com a releitura do mundo, mas também à crença de que existe um universo literário infantil, tendo como sujeitos enunciadores indivíduos apropriados de um "saber adulto". (GREGORIN, 2009, p. 1819).

Dessa maneira, verbal e visual, em relação, ao anunciarem uma Chapeuzinho Amarelo com cor vermelha no corpo das letras, evidenciando o título da obra, ratificam uma dada permanência do clássico, presente ainda em outro momento significativo do texto Chapeuzinho Amarelo e que resgata, de maneira referencial, o famoso diálogo da narrativa 
de Perrault entre a Chapeuzinho Vermelho e o Lobo Mau (cujo encontro rompe os espaços das páginas e ambos ficam frente a frente) como se pode ver no quadro abaixo, corroborado pelas figuras 20 e 21 , na sequência.

\section{Chapeuzinho Vermelho - Charles Perrault}

“- Vovó, como são grandes os seus braços!

- É para melhor te abraçar, minha filha!

- Vovó, como são grandes as suas pernas!

- É para poder correr melhor, minha netinha!

- Vovó, como são grandes as suas orelhas!

- É para ouvir melhor, netinha!

- Vovó, como são grandes os seus olhos!

- É para ver melhor, netinha!

- Vovó, como são grandes os seus dentes!

- É para te comer!"

\section{Chapeuzinho Amarelo - Chico Buarque}

“(...) carão de LOBO,

olhão de LOBO,

jeitão de LOBO

e principalmente um bocão

tão grande que era capaz

de comer duas avós,

um caçador,

rei, princesa,

sete panelas de arroz

e um chapéu

de sobremesa." 


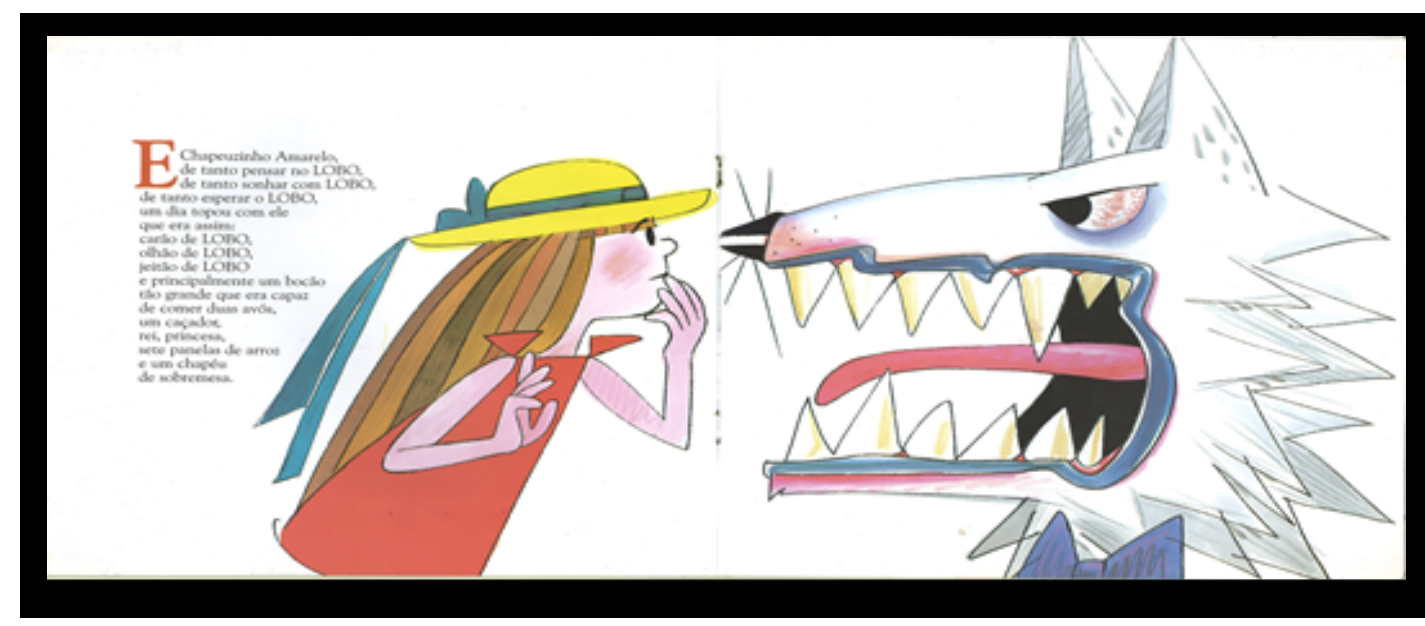

Fonte: Buarque, Ziraldo (2006)

Agora, novamente, convidado a olhar para toda a extensão da capa da obra de Buarque e Ziraldo (figura 22), é possível ver uma articulação interessante entre as linguagens verbal e visual e o efeito que, juntas, podem criar para compor a unidade de sentido do texto que se apresenta. Assim, a ilustração de uma menina no centro da página, com um vestido vermelho, sem mangas, cabelos lisos e longos, uma franja com um corte muito reto encobrindo toda a testa, rosto redondo, olhos negros e vivos, pele rosada e um chapéu de abas grandes (que quase ultrapassam as margens direita e esquerda do livro, num amarelo de tom tão vibrante e imponente que chamam para si um olhar em particular), com uma fita azul em formato de laço na cabeça, começa a revelar, sobretudo, pela disposição das formas, muito mais coisas do que fora possível ler inicialmente.

A figura, do que parece ser o simulacro de uma jovem menina, faz com que se olhe para ela e para seu chapéu, de modo especial. Afinal, ela também olha para o seu enunciatário (leitor), quando é vista esboçando um sorriso aparentemente contido e convidativo. E nesse momento se estabelece, além do efeito de interlocução, um certo contrato de veridiç̧ão, pressuposto no ato de se fazer crer contar uma história que ao mesmo tempo em que se apresenta como nova, vai sendo denunciada pelos traços da personagem já bem conhecida pelo leitor, como é possível ver ao se retomar novamente a imagem da menina, a seguir. 
Figura 22 - Chapeuzinho Amarelo: identidade

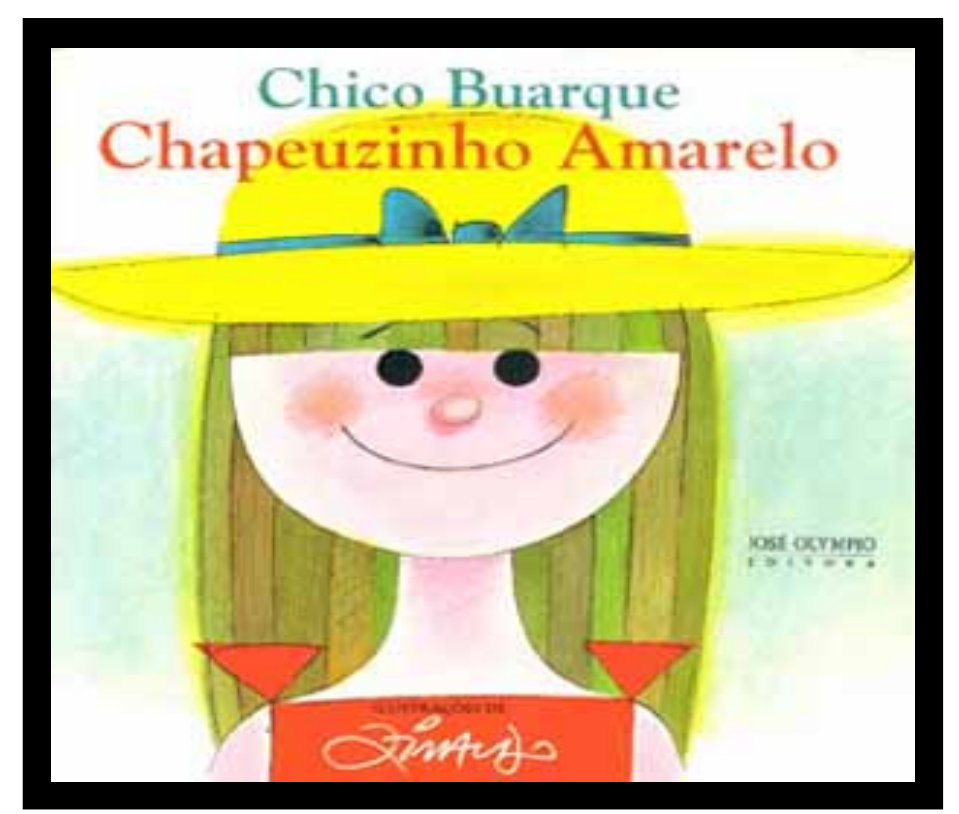

Fonte: Buarque, Ziraldo (2006)

Aliado a esse fazer, está o cromatismo (cores), em toda a extensão da primeira e quarta capas (figuras 22 e 23), que resgatam por meio das cores verde, amarelo azul e branco, não só as cores da bandeira do Brasil, criando um efeito de sentido de pertença, mas a autoafirmação de uma identidade, marcada pela nacionalidade do sujeito cidadão leitor a que se destina a obra - pertencente a um determinado grupo que partilha dos mesmos valores e culturas. De acordo com Santos (2013, p.169): “A preocupação com a identidade não é, obviamente, nova. Podemos dizer até que a modernidade nasce dela e com ela. O primeiro nome moderno da identidade é a subjetividade.”

Esse traço identitário pode ser visto pela forma do corpo do simulacro menina: postura ereta, braços colados ao corpo e enquadramento da imagem a partir dos ombros, num fundo branco e azul, tal qual uma fotografia $(3 \times 4)$ para documentos oficiais de identificação. Nesse tocante, observa-se, ainda, que na imagem há a projeção de longos cabelos em que mechas intercaladas em verde e amarelo (em tons esmaecidos) sugerem um lugar específico - país - Brasil. Todos esses elementos em relação a outros vistos no texto são autorizados por um plano de expressão (verbal e visual) e por um plano de conteúdo (verbal e visual) a compor o fazer interpretativo do enunciatário criança marcado nesse discurso literário. 
Nota-se, escrito na parte superior do texto capa, bem acima do título da obra citada, no espaço em branco e também centralizado, o nome do autor (em verde, traço que retoma as questões de identidade e nacionalidade, discutidas anteriormente), com o mesmo tamanho e tipo de letra conferidos à obra, parecendo revelar certa intimidade ou parceria entre ambos. Essa topologia (alto) constrói o efeito de pertença e poder ao enunciador (autor) que, conhecendo a identidade do seu público-alvo projetado também no texto e motivado pelo lugar comum - história com a qual, de alguma maneira, já entrou em contato - aceita a promessa do autor e assume o contrato que o coloca frente ao texto novo.

Do mesmo modo, é possível observar na parte inferior da capa (rodapé), o nome do ilustrador Ziraldo, com letra manuscrita pelo próprio artista (como espécie de assinatura ou identidade), em cor branca e sobre a imagem central, determinando o lugar de onde o ilustrador fala, ou seja, lugar como autor também do texto-imagem, cuja linguagem visual em parceria com a verbal projetam diferentes significações no tecido textual atualizado. Ao mesmo tempo esse novo arranjo constrói uma forma diferente de ser o texto literário, pois em passados não tão distantes, a ilustração figurava numa relação em que seus autores não tinham o reconhecimento como tal.

Essas mudanças levam a pensar, de certo modo, que o próprio texto literário, no início do século XIX, sofreu pelos impasses no seu reconhecimento como uma arte literária real para a infância por conta do enaltecimento do brio nacionalista ou da pátria sempre idolatrada. Mais do que isso, é possível pensar aqui, nesse tecer de linguagens em processo de mudança, o prenúncio do surgimento de um movimento que nasce junto com o reconhecimento do Modernismo e suas transformações, quebras de paradigmas e novas perspectivas em meio a ajustes.

A quarta capa da obra (figura 23) traz um fundo todo em amarelo esmaecido diferentemente do usado no chapéu da primeira capa. Contudo, este surge em tamanho menor, centralizado na página, ocupando o alto - parte superior - sem a mesma imponência (dada pelo tamanho) em que fora visto na cabeça da menina na primeira capa. Abaixo do chapéu, eis que está o verbal com a missão de apresentar a identidade de cada autor atestando, em seu conteúdo, que se trata de autores brasileiros. 
Figura 23 - Chapeuzinho Amarelo: quarta capa

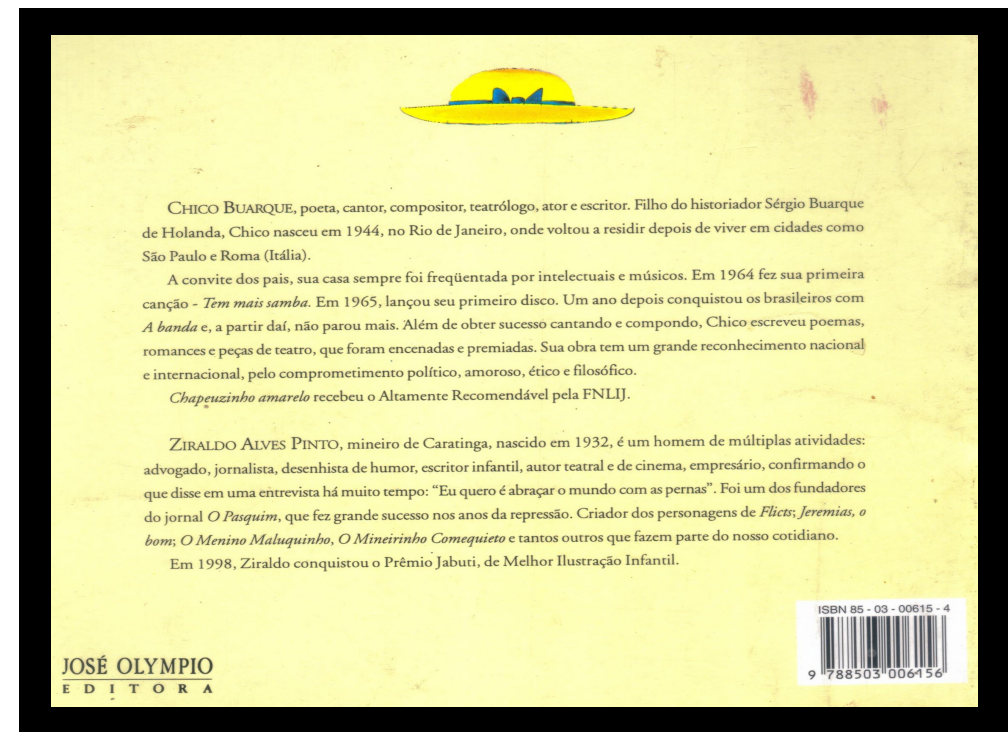

Fonte: Buarque, Ziraldo (2006)

A partir da leitura que se iniciou nas capas da obra, adentra-se mais na narrativa de Chapeuzinho Amarelo (figura 24), observando-se marcas que remetem a uma dada estrutura clássica do conto e seus arranjos mais formais, reminiscências do século XVII, como, por destaque, a letra inicial com característica capitular (herança das iluminuras medievais) e a remissão ao tempo passado, dado pelo verbo no pretérito imperfeito, cujo efeito de sentido faz crer um tempo indeterminado, num espaço qualquer, como é próprio das narrativas ficcionais dos contos de fada ("Era uma vez...") como se pode ver, a seguir:

Era a Chapeuzinho Amarelo.

Amarelada de medo.

Tinha medo de tudo, aquela Chapeuzinho.

Já não ria.

Em festa, não aparecia.

Não subia escada

nem descia.

Não estava resfriada

mas tossia.

Ouvia conto de fada

e estremecia.

Não brincava mais de nada, nem de amarelinha. (BUARQUE, ZIRALDO, 2006). 
Figura 24 - Amarelada de medo

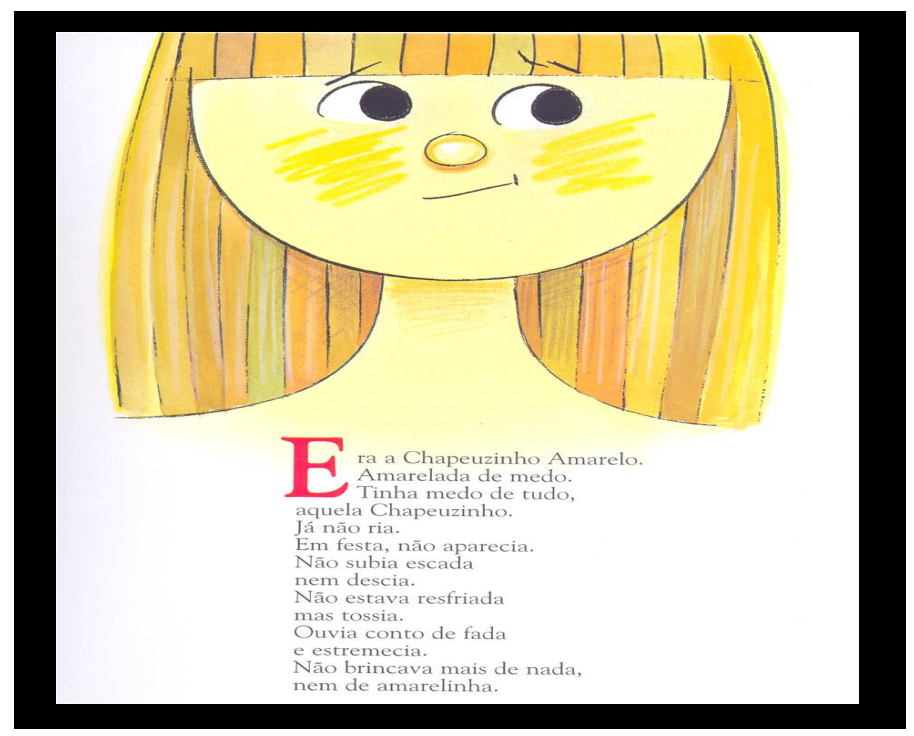

Fonte: Buarque, Ziraldo (2006)

Nesse tocante, instaura-se no tecido textual narrativo um efeito de tempo inacabado, marcado pelo sema "era", com o qual se constrói esse tempo verbal. Nesse contrato estabelecido pelo narrador com seu leitor há, desde a capa, como visto inicialmente, um contrato firmado de que será contada uma história já bem conhecida de todos: a de uma menina com seu chapéu ou capuz vermelho.

Tal fato é, ainda, reforçado pela letra E (em caixa alta e na cor vermelha) que figura como ilustração instigante, nesse contexto, uma vez que vermelho é a cor do chapéu da menina da história consagrada pelos registros de Charles Perrault, Chapeuzinho Vermelho, portanto, e pela versão dos irmãos Grimm, já mencionada. Sem dúvida, isso mostra que as obras destes autores, muitas vezes misturadas, serviram e servem de referência a várias versões, em diferentes suportes, que ainda hoje permeiam o imaginário da criança e do jovem. O que pode ser confirmado no texto Chapeuzinho Amarelo, que traz na passagem do diálogo com o lobo (figuras 20 e 21) a personagem caçador (da versão dos irmãos Grimm): “(...) e principalmente um bocão/tão grande que era capaz/de comer duas avós,/um caçador,(...)."

Da mesma forma, é na narrativa poética, de Chico Buarque, que se vê o anunciar de outra menina: a do Chapeuzinho Amarelo. E aqui é importante observar que a 
marca do dêitico (pronome demonstrativo "aquela"; figuras 29 e 30): "O lobo ficou chateado/de ver aquela menina/olhando pra cara dele/só que sem o medo dele.”), ao mesmo tempo em que pressupõe tratar-se de uma Chapeuzinho como sujeito de outro tempo e espaço, ou seja, aquela, lá (passado - França-Alemanha) e não essa, aqui (presente - o Brasil), acompanhado dos verbos no passado, cria uma dada ambiguidade que reforça a ideia de que se trata também de um sujeito - Chapeuzinho Amarelo, em processo de transformação, saindo de suas não ações (sujeito em conflito) para as ações (sujeito capaz de vencer os conflitos).

Esse fato pode ser apreciado com a recuperação do tempo no presente, projetado no momento em que o sujeito menina se coloca frente a frente com o medo que a oprime, verificando que o medo que ela havia criado do próprio medo não era tão pavoroso assim, portanto, reconhecendo-se capaz de vencê-lo, libertar-se. Por essa ação ela é sancionada positivamente e recebe como prêmio a liberdade, rompendo com a projeção dela no início da narrativa, antes do encontro com o lobo, e o sujeito transformado, depois do encontro com o lobo - representação dada pelas ações no passado (era, tinha...) e no presente, bem marcado com o uso de agora (come, tem...), como se pode ver na relação de oposição dessa ações, organizadas no quadro (opressão x liberdade), adiante.

Nesse contexto, é importante pensar como a escolha, de Buarque, pela estrutura poética reforça uma qualidade estética que finda por reiterar a valora do percurso do sujeito menina. Dessa maneira, a escolha pela poesia ${ }^{16}$, enquanto categoria estética, para contar a história da menina do chapéu amarelo e do lobo reforça o valor do lúdico como estratégia de captação do leitor. Questão que, no Brasil, só foi possível ver, de modo expansivo, a partir da década de 80, de acordo com Zilberman (2014), uma vez que o lúdico não era questão central dos poemas destinados à criança do começo da literatura infantil brasileira. Esse período teve como principal representante o poeta Olavo Bilac e sua obra carregada por uma temática de orientação cívica e de predominância de intenções didáticas, seguido por Francisca Júlia (1871-1920) que, igualmente a Bilac, insistia em uma estética parnasiana. Foi, portanto, somente depois de 1980 que se descobriu a poesia

\footnotetext{
${ }^{16}$ De acordo com Paz (1982, p.138) significa dizer: "O homem é sua imagem: ele mesmo e aquele outro. Através da frase que é ritmo, que é imagem, o homem - esse perpétuo chegar a seu - é. A poesia é entrar no ser."
} 
para crianças, cuja produção de caráter plástico e estético ${ }^{17}$, como é possível observar no texto de Buarque, cresceu de modo não só quantitativo, mas qualitativo. Isso posto, é válido ressaltar que:

A valorização do lado lúdico da linguagem propiciou a expansão da poesia endereçada à infância, a partir dos anos 1980. Introduzindo, nos versos e nas estrofes, a perspectiva da diversão, do jogo e da brincadeira, o gênero poético pôde se livrar dos problemas que experimentou principalmente na primeira metade do século XX. O elenco de autores diversificou-se, e várias possibilidades expressivas apareceram, passando a constituir as características mais importantes da poesia direcionada prioritariamente ao público formado por meninos e meninas brasileiras. (ZILBERMAN, 2014, p. 132).

\section{Opressão x Liberdade}

"Era a Chapeuzinho Amarelo.

Amarelada de medo.

Tinha medo de tudo, aquela Chapeuzinho.

Já não ria.

Em festa, não aparecia.

Não subia escada

nem descia.

Não estava resfriada

mas tossia.

Ouvia conto de fada

e estremecia.

Não brincava mais de nada, nem de amarelinha."
“(...) Aliás, ela agora come de tudo, menos sola de sapato.

Não tem mais medo de chuva nem foge de carrapato

Cai, levanta, se machuca, vai à praia, entra no mato, trepa em árvores, rouba fruta, depois joga amarelinha com o primo da vizinha, com a filha do jornaleiro, com a sobrinha da madrinha e o neto do sapateiro."

\footnotetext{
${ }^{17}$ Zilberman, em A literatura infantil brasileira (2014) organiza uma relação em que é possível ver o florescimento do gênero poético (1980 a 2000), dedicado às crianças, cujo uso de técnicas $e$ princípios de criação artística adotavam parâmetros mais livres e libertários.
} 
Há de se considerar no percurso de aquisição dos valores (competências) necessários para a realização das ações, ou passagem de um estágio a outro da menina, as marcas da opressão x liberdade como configurações importantes, sobretudo se se pensa a época, 1979, - período de vigor do regime militar no Brasil -, em que o texto fora editado pela primeira vez. Não obstante a isso têm-se, o simulacro de Brasil com suas misturas raciais e diferenças sociais - diversidades culturais em construção; processos multiculturais - (figuras 25 e 26), configuradas num mesmo espaço em que convivem: o primo da vizinha, a filha do jornaleiro, a sobrinha da madrinha e o neto do sapateiro.

Figuras 25 - Não comeu aquele bolo de lobo

Figura 26 - Liberdade

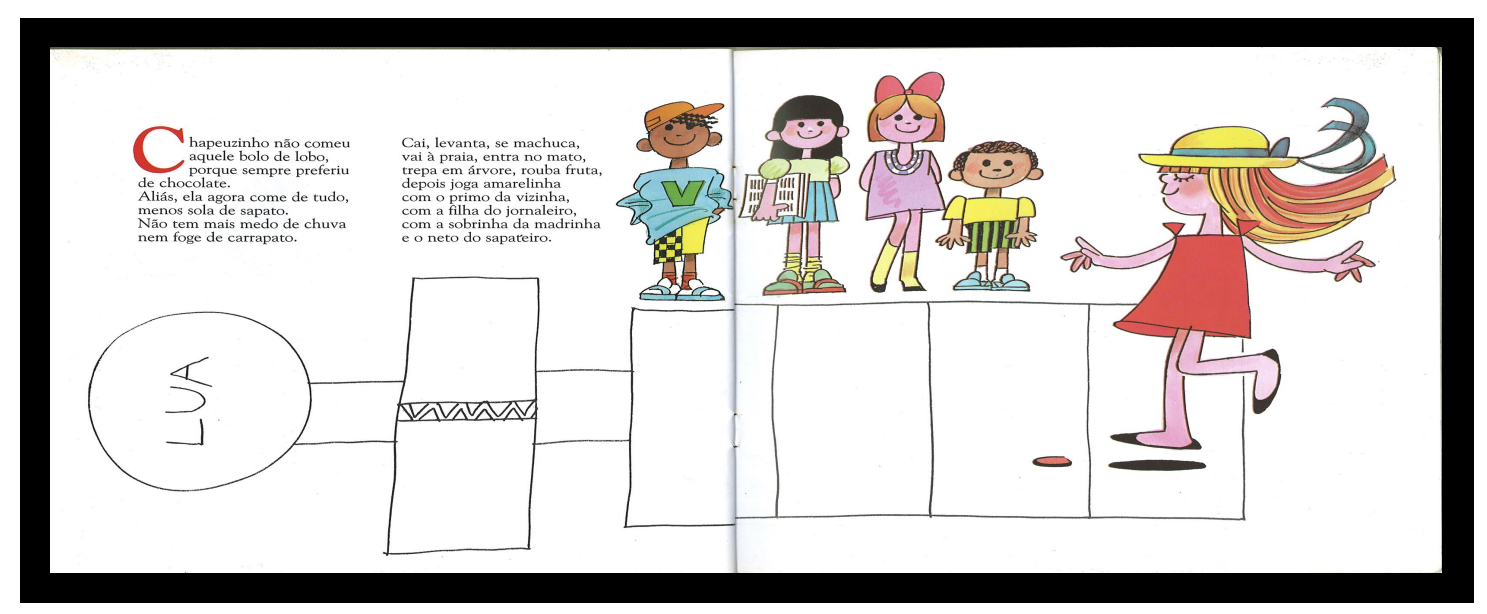

Fonte: Buarque, Ziraldo (2006)

Percebe-se, inscrito nesse contexto, um certo apelo às transformações anunciadas pelo Modernismo e seus momentos de transfiguração no cenário da literatura, do século XX, como reflexos históricos, sociais e étnicos. Sobre isso, Candido diz:

O nosso Modernismo importa essencialmente, em sua fase heroica, na libertação de uma série de recalques históricos, sociais, étnicos, que são trazidos triunfalmente à tona da consciência literária. Este sentimento de triunfo, que assinala o fim da posição de inferioridade no diálogo secular com Portugal e já nem o leva mais em conta, define a originalidade própria do Modernismo na sua dialética do geral e do particular.

Na nossa cultura há uma ambiguidade fundamental: a de sermos um povo latino, de herança cultural europeia, mas etnicamente mestiço, situado no trópico, influenciado por culturas primitivas, ameríndias e africanas. 
O Modernismo rompe com este estado de coisas. As nossas deficiências, supostas ou reais, são reinterpretadas como superioridades. (CANDIDO, 2006, p. 127).

É dessa maneira, que a escolha intencional de um texto poético para a organização do conto de outrora, reconfigura não só a estrutura narrativa, gerada pela qualidade estética do gênero, mas os sentidos dos sujeitos captados pelo texto visual cuja qualidade plástica corrobora o valor do dito. A poesia, por assim dizer, divide sua magia com o conto de fada para fazer emergir os estados de alma do sujeito menina, reforçando valores que não são apenas da estrutura do poema como imagem que o é, mas, sobretudo representação da própria transformação do ser. Pois, como manifesta Octavio Paz:

A poesia é metamorfose, mudança, operação alquímica, e por isso confina com a magia, a religião e outras tentativas para transformar o homem e "fazer" ou "daquele" esse "outro" que é ele mesmo. O universo deixa de ser um vasto armazém de coisas heterogêneas. Astros, sapatos, lágrimas, locomotivas, salgueiros, mulheres, dicionários, tudo é uma imensa família, tudo é uma imensa família, tudo se comunica e se transforma sem cessar, um mesmo sangue corre por todas as formas e o homem pode ser, por fim, o seu desejo: ele mesmo. A poesia coloca o homem fora de si e simultaneamente o faz regressar ao seu ser original: volta-o para si. (PAZ, 1982, p. 137).

O lúdico da linguagem em verso transborda para a linguagem visual (figuras 35 e 36), e é possível ver a menina brincando; pulando amarelinha, num processo de reconfiguração do amarelo que antes representava o medo; a opressão que a mantinha pressa no próprio quarto (mente), uma espécie de caverna imaginária, mas que agora é transformada em "amarelo da liberdade" por meio do jogo, da brincadeira, ou porque não dizer do amarelo que representa a luz transformadora na vida da menina, questão essa corroborada pelo verbal:

Chapeuzinho não comeu aquele bolo de lobo, porque sempre preferiu de chocolate.

Aliás, ela agora come de tudo, menos sola de sapato.

Não tem mais medo de chuva/nem foge de carrapato.

Cai, levanta, se machuca, vai à praia, entra no mato, trepa em árvores, rouba fruta, depois joga amarelinha (...). (BUARQUE, 2006). 
E que remete, de certa forma, ao célebre diálogo em A alegoria da caverna, de Platão - A República:

Sócrates: E agora, meu caro Glauco, é preciso aplicar exatamente essa alegoria ao que dissemos anteriormente. Devemos assimilar o mundo que apreendemos pela vista à estada na prisão, a luz do fogo que ilumina a caverna à ação do sol. Quanto à subida e à contemplação do que há no alto, considera que se trata da ascensão da alma até o lugar inteligível, e não te enganarás sobre minha esperança, já que desejas conhecê-la. Deus sabe se há alguma possibilidade de que ela seja fundada sobre a verdade. Em todo o caso, eis o que me aparece tal como me aparece; nos últimos limites do mundo inteligível aparece-me a ideia do Bem, que se percebe com dificuldade, mas que não se pode ver sem concluir que ela é a causa de tudo o que há de reto e de belo. No mundo visível, ela gera a luz e o senhor da luz, no mundo inteligível ela própria é a soberana que dispensa a verdade e a inteligência. Acrescento que é preciso vê-la se quer comportar-se com sabedoria, seja na vida privada, seja na vida pública. (PLATÃO, 2000, 514a-517c).

Nesse jogo entre as linguagens, é a intertextualidade visual (figuras 35 e 36) por meio da imagem de Chapeuzinho Amarelo, pulando amarelinha em direção à Lua, que traz à tona duas referências da literatura infantil brasileira à obra de Buarque e Ziraldo. A primeira é a personagem Emília, de Monteiro Lobato, cujas características marcantes, boneca de pano, olhos de retrós preto, sobrancelhas lá em cima, desde a sua primeira aparição, podem ser encontradas nas descrições feitas pelo autor em $A$ menina do nariz arrebitado, de 1920, ou em representações diversas realizadas por renomados ilustradores como Voltolino ${ }^{18}$ e Belmonte ${ }^{19}$, por exemplo, que deixaram seus traços e estilos impressos na personagem Emília, e que de algum modo são atualizados pelos traços de Ziraldo.

Nesse contexto, a fala é outra característica marcante da boneca que tem a "língua solta", por assim dizer, e não deixa de falar o que pensa. Esta personagem, de muitas maneiras, revela-se como representante inconteste da consciência crítica e da liberdade de expressão de Lobato (um dos maiores responsáveis pela formação da identidade da literatura infantil e juvenil no Brasil), ao mesmo tempo em que configura,

\footnotetext{
18 João Paulo Lemmo Lemmi (1884-1926), desenhista, ilustrador, caricaturista, foi o responsável pelas ilustrações coloridas da primeira edição de A menina do nariz arrebitado, de 1920).

${ }^{19}$ Benedito Bastos Barreto (1897-1947), entre os anos de 1929 e 1937 ilustra cinco obras infantis de Monteiro Lobato (1882-1948).
} 
ironicamente, o estereótipo do feminino ${ }^{20}$, reconstruído num espaço social e numa temporalidade onde a mulher ainda era obrigada a calar porque falava demais ou ainda porque o que dizia tinha pouca valia.

São construções textuais como essas, dadas pela linguagem verbal e pela linguagem visual, que, em diálogo, vão tecendo sentidos por meio da intertextualidade prescrita e iluminando percepções sobre as mudanças no modo de se contar as histórias de todos os tempos. Para Bakthin:

O texto só ganha vida em contato com outro texto (com contexto). Somente neste ponto de contato entre textos é que uma luz brilha, iluminando tanto o posterior como o anterior, juntando dado texto a um diálogo. Enfatizamos que esse contato é um contato dialógico entre textos... Por trás desse contato está um contato de personalidades e não de coisas. (BAKTHIN, 1986, p.162).

A segunda referência, mencionada anteriormente, é a personagem Flicts, de Ziraldo, da obra de mesmo nome, cuja primeira edição se deu em 1969, mesmo ano em que o homem foi à Lua pela primeira vez, o que, de certa forma, justifica pela referencialidade o final dessa narrativa: “A Lua é Flicts”. É possível notar, diante dessa marca intertextual vista na imagem, uma certa ação de liberdade, de reconhecimento da identidade e do lugar no mundo ao qual pertence o sujeito menina, tal qual o valor de Flicts e seu estado de ser, cuja representatividade simbólica se traduz pelo dizer poético de Drummond, na quarta capa da obra de Ziraldo:

... Flicts é a iluminação - afinal, brotou a palavra - mais fascinante de um achado: a cor, muito além do fenômeno visual, é estado de ser, e é a própria imagem. Desprende-se da faculdade de simbolizar, e revela-se aquilo em torno do qual os símbolos circulam, voejam, volitam, esvoaçam - fly, flit, fling - no desejo de encarnar-se. Mas para que símbolos, se captam o coração da cor? Ziraldo realizou a façanha, em seu livro. (ZIRALDO, 2006).

\footnotetext{
${ }^{20}$ Segundo Zilberman (2014), foi novamente Lobato, no Brasil, quem conferiu primeiro plano às personagens femininas. Assim, Lúcia, a Menina do Narizinho Arrebitado deu nome ao livro de estreia do autor, em 1921. Emília, a boneca-gente, por sua vez, tomou conta da saga do sítio do Picapau-Amarelo e liderou as aventuras por várias partes do mundo (veja-se em Geografia de Dona Benta, de1937), varou tempo, deslocando-se para a Antiguidade Clássica (vejam-se O Minotauro e Os doze trabalhos de
} 
Por outro lado, observa-se que o texto Chapeuzinho Amarelo, de Chico Buarque e Ziraldo, de certa maneira, carnavaliza o processo que Monteiro Lobato utilizou na organização de seus textos, em que várias personagens de obras da literatura brasileira e estrangeira, mantendo suas individualidades marcantes, circulam num mesmo espaço textual. O autor, ao propor o já conhecido ou esperado, capta a atenção do leitor pela familiaridade, para em seguida apresentar o desconhecido como se esse fosse totalmente novo.

Tal processo de reconhecimento e retomada de outras histórias num mesmo tempo, inscreve, de acordo com Zilberman (2014), situações já vivenciada por Ana Maria Machado, em sua obra Amigos secretos (1996) quando ela apresenta um grupo de amigos que, por força de eventos fantásticos, vão conviver com as personagens do sítio do Picapau Amarelo, de Monteiro Lobato, além de outras que ele vai inserindo na narrativa como, Peter Pan, por exemplo. Esse movimento que não se restringe apenas às obras de Machado, é um fato revelador da maturidade da literatura infantil brasileira e, de certo modo, explica, os mecanismos utilizados por Buarque e Ziraldo, pois:

O déjà-vu, no caso de Amigos secretos, inscreve-se sobe a obra de Monteiro Lobato, que, da sua parte, tinha procedido dessa maneira a partir da literatura estrangeira, sobretudo europeia. Agora, é ele quem fornece os padrões a serem incorporados pelos autores nacionais, oferecendo-se como modelo e espaço de intertextualidade. O espelho utilizado para os novos autores se mirarem não mais provém de fora, mas de dentro de nossa tradição, aparecendo o criador de Narizinho e Emília como o clássico a reverenciar e, ao mesmo tempo, transgredir. (ZILBERMAN, 2014, p.170-171).

Por conseguinte, o estreito diálogo entre as personagens Chapeuzinho Amarelo e Vermelho perpassa por questões como o bem e o mal, embora a relação do medo do lobo; medo do desconhecido seja posta sob ângulos diferentes, uma vez que o medo, predominantemente, em Perrault é visto fora do sujeito Chapeuzinho - na alteridade, enquanto em Chapeuzinho Amarelo o medo está no próprio sujeito menina, na identidade (si mesmo), assim como a possibilidade de mudança e de superação.

Há, ainda, neste percurso um diálogo, via cromatismo, bastante significativo e revelador, tendo em vista as mudanças ocorridas na própria construção desses sujeitos meninas (do presente e do passado) que assumem uma dada identidade pela cor que as 
representa, a vermelha e a amarela respectivamente. Assim, Pedrosa (1989, p.109) em sua obra $\mathrm{Da}$ cor à cor inexistente discute sobre a significação das cores e os estados anímicos provocados pelo vermelho e ao fazê-lo cita Kandinsky, para quem: "O vermelho claro quente (Saturno) tem certa analogia com o amarelo médio. Força, ímpeto, energia, decisão, alegria, triunfo, é tudo isto que ele evoca. (...)". E, ainda, a respeito do vermelho, Pedrosa traz a seguinte definição:

Cor do fogo e do sangue, o vermelho é a mais importante das cores para muitos povos, por ser a mais intimamente ligada ao princípio da vida. As contraditórias características físicas do vermelho deram origem à bivalência de imagens inspiradas por elas, surgindo entre os alquimistas a ideia simbólica de dois vermelhos, um noturno, fêmea, possuindo um poder de atração centrípeta, e o outro diurno, macho, centrífugo.

$\mathrm{O}$ vermelho noturno, centrípeto, era visto como a cor do fogo central que anima o gênero humano e a terra. Estava ligado ao centro onde se operam a digestão, o amadurecimento, a regeneração do ser ou da obra em elaboração Era a cor da alma da libido e do coração. É a cor da ciência, do conhecimento esotérico, interditada aos não iniciados. O vermelho diurno, centrífugo, invade o espaço. E tanto para o profano como o sagrado, torna-se sinônimo de juventude, de saúde, de riqueza e de amor. (PEDROSA, 1989, p. 109).

Nessa relação, sobre a significação do amarelo, Pedrosa diz que:

Apesar da variedade de significados atribuídos ao amarelo nos diversos períodos históricos, o que se evidencia, em todos os tempos, é sua íntima ligação com o ouro, o fruto maduro e o sol. [...].

Amplo e ofuscante como uma corrida de metal incandescente, é a mais desconcertante das cores, transbordando dos limites onde se deseja encerrá-lo, parecendo sempre maior do que é na realidade, devido à sua característica expansiva. Segundo Kandinsky, o amarelo, representando o calor, a energia e a claridade, assume a primazia do lado ativo das cores, em oposição à passividade, frigidez e obscuridade representadas pelo azul. Olhando-o fixamente, "percebe-se logo que o amarelo irradia, que realiza um movimento excêntrico e se aproxima quase visivelmente do observador. (PEDROSA, 1989, p. 111).

Desse modo, na descrição do verbal e do visual (figura 24), contemplam-se os primeiros traços do sujeito anunciado: "Era a Chapeuzinho Amarelo./Amarelada de medo./ Tinha medo de tudo,/aquela Chapeuzinho. (...)”. A organização poética, dada pelo verbal, apresenta um sujeito criança apartada da infância e diferentemente da aparição dela na primeira capa, agora há uma ilustração da menina em que não apenas a pele de rosada passa 
a amarelada, mas também a face, os cabelos e o pescoço. Por conseguinte, sua cabeça, sem o chapéu, ultrapassa o limite da parte superior da página do livro, dando espaço ao verbal que assume a função descritiva do medo refletido na face "amedrontada" da menininha (sobrancelhas baixas, olhos arregalados e direcionados para o lado direito da página, boca deslocada para o mesmo lado dos olhos) e também se faz ver como extensão do corpo do sujeito tomado por um dado temor comum na passagem da infância à vida adulta.

Observa-se, assim, que o estreito diálogo entre a expressão verbal e visual organiza um arranjo na página inicial da história, em que se tem a parte superior ocupada pela ilustração propriamente dita e a inferior pelo o texto verbal, ambos centralizados na página - numa estrutura própria do poema, ou seja, uma estrofe com quatorze versos que descrevem as não qualidades da menina, confirmando, por sua vez, a separação ou disjunção da personagem com a coragem, passaporte fundamental para a liberdade e reconhecimento de si como sujeito no mundo em que lhe confere viver - continuidade do corpo desta, Chapeuzinho Amarelo, como forma de atestar o estado ou modo de ser do sujeito menina de que a história deve tratar.

$\mathrm{Na}$ relação entre as duas personagens, observa-se que elas se diferenciam a partir de traços que se assemelham. Isso tanto na representação verbal - alusão a certas passagens do texto matriz quanto na representação visual - cromatismo via disco redutivo de cores (figura 31) que recombinando os matizes gera possibilidades cromáticas perceptíveis e sensíveis. Uma personagem é, portanto, ressaltada pela cor vermelha e a outra pela cor amarela, classificadas como cores quentes, sendo o amarelo quente por excelência, uma vez que o vermelho é sempre influenciado e, variando ou pelo azul ou pelo amarelo, penderá para um vermelho quente ou para um frio. Essas cores, de certa maneira, assumem uma representatividade marcante quando se pensa que o vermelho de Perrault ou dos irmãos Grimm é trazido à tona pelo amarelo de Buarque e Ziraldo para representar um texto novo.

A narrativa verbal de Buarque, além de dar novo enfoque à temática do medo, reorganiza os valores do ponto de vista do tempo, do espaço e do próprio sujeito, bem como reordena questões latentes na essência daquelas narrativas de outros tempos como, por exemplo, os fins a que elas se destinavam, ou seja, moralizar, modelar, doutrinar ou apenas 
entreter. Isso desde suas origens e até mesmo quando elas caíram no gosto da criança e passaram, a posteriori, a ser destinadas ao público infantil e juvenil.

É importante observar que a narrativa (figura 24), por sua vez, reordena um jogo com o avesso e o direito do símbolo, dado que no amarelo há o investimento positivo, mas há também o negativo, organizados por valores de ordem cultural que fazem surgir expressões como: "amarela (o) de medo"; "branca (o) de medo" (figuras 27 e 28), podendo ainda, como no caso da cor branca, ter o sentido de desaparecimento, ao passo que também carrega a ideia de preenchimento. O branco, enquanto significação está presente no todo da obra de Buarque e Ziraldo, servindo de fundo e representação tanto para destacar as imagens verbais e visuais, quanto para ilustrar as transformações ocorridas no percurso do sujeito Chapeuzinho Amarelo. Assim, de acordo com a definição de Pedrosa:

Do ponto de vista físico, o branco é a soma das cores; psicologicamente, é a ausência delas. O branco é sempre o ponto extremo em qualquer escala: partindo da luminosidade em direção às trevas, ele é o ponto inicial; das trevas em direção à luz, é o término. [...] Também os sentidos simbólicos emprestados ao branco decorrem dessa singularidade de sua natureza, que faz lembrar as duas extremidades da infinita linha do horizonte onde surgem a noite e a alba.

Em vários rituais místicos, é a cor indicativa das mutações e transições do ser. Segundo o esquema tradicional de toda iniciação, ele representa morte e nascimento ou ressurreição. (PEDROSA, 1989, 117).

Figura 27 - Medo de tudo

Figura 28 - Branca de medo

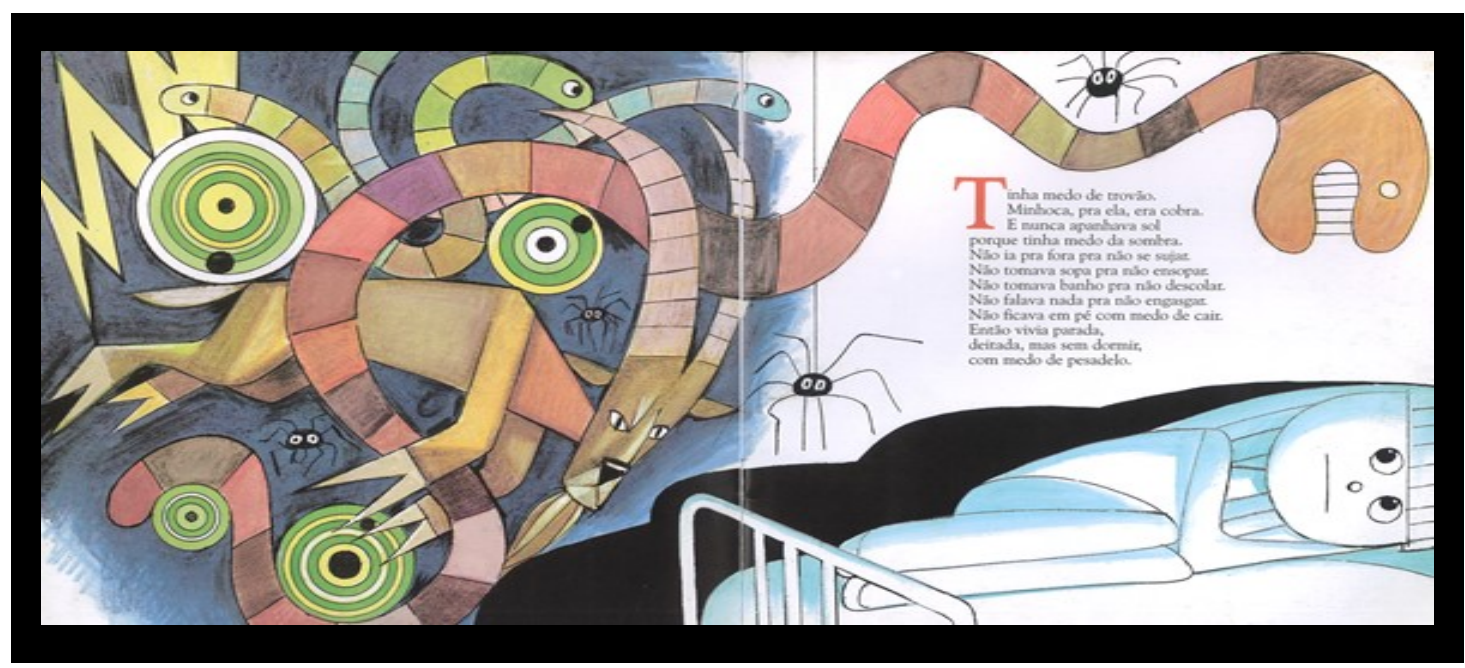

Fonte: Buarque, Ziraldo (2006) 
Na passagem (figuras 29 e 30) em que o Lobo deixa de representar medo para a menina, observa-se uma atenuação da figura dessa personagem aterrorizadora, cujo verbal num processo de gradação vai desconstruindo a figura do lobo de tal modo que a própria palavra "LOBO" que até o momento do encontro com a menina era escrita com letras maiúsculas, depois disso, passa a ser grafada com letras minúsculas - "lobo" -, numa espécie de representação do apagamento do temor que a menina tinha, até encarar o lobo, olhá-lo bem de pertinho. Nesse processo, o Lobo é mostrado pela predominância do branco que denuncia, agora, a troca de lugares, ou seja, da menina sem medo para o lobo (desqualificado): "branco de vergonha ou medo":
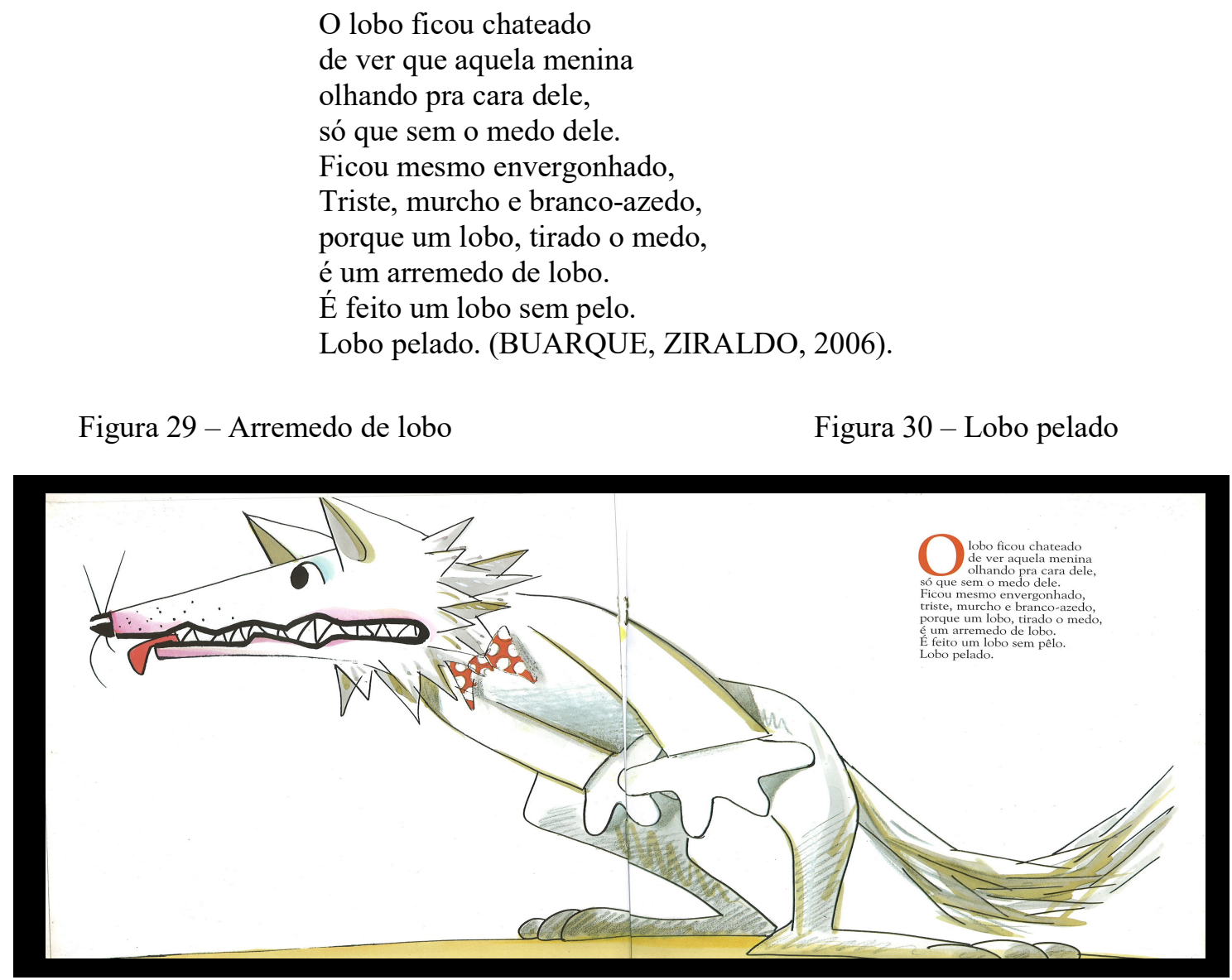

Fonte: Buarque, Ziraldo (2006)

Essa mudança de atitude é um ponto alto na narrativa, uma vez que a Chapeuzinho Amarelo é mostrada, desde o início, como sujeito incapaz de lidar com os 
seus medos (figuras 27 e 28), uma vez que, sendo criança, ela não tem maturidade suficiente para encarar os desafios da vida que começam a surgir no percurso de seus próprios sentimentos. As duas páginas, assim, corroboram a ideia do medo como temática que rege a vida da Chapeuzinho Amarelo, cujo pavor é enfatizado pela partícula de negação "não" (como visto na estrutura poética de doze versos em que o "não" se repete no início e meio de quatro dos cinco versos, e no quinto apenas no início: “(...) Não ia pra fora para não ensopar/Não tomava banho pra não descolar./Não falava nada pra não engasgar./Não ficava em pé com medo de cair.

Há, ainda, uma visível e instigante integração entre páginas (figuras 38 e 39), em que a visualidade de uma página invade a outra para também dizer sobre os sentimentos da menina diante do seu caos interior. São imagens "bizarras", próprias do pesadelo, alucinação, distúrbio mental ou mesmo do imaginário, como quer fazer crer a narrativa verbo-visual.

$\mathrm{Na}$ imagem projetada à esquerda (figura 38), portanto, de um fundo escuro vê-se saltar uma enorme cobra, além de minhocas, aranhas, raios e até um bode em meio a figuras de formatos circulares (tamanhos variados) e matizes cromáticas que se alternam nas cores verde (tonalidades diferentes), amarelo, branco e preto, confirmando o efeito de terror e paralização da menina diante das imagens do medo" que a invade". Tal imagem alucinante é gerada a partir da diferença ou ampliação de percepção das cores por meio do disco redutivo de cores ${ }^{21}$ em graus de rotação como pode ser visto, a seguir (figura 31).

\footnotetext{
${ }^{21}$ Ver mais sobre o assunto no capítulo 4: Óptica fisiológica, p. 67-79, em PEDROSA, Israel. Da cor à cor inexistente. Rio de Janeiro: Léo Christiano Editorial Ltda., $5^{a}$ Edição, coeditado pela Editora Universidade de Brasília, 1989.
} 
Figura 31 - Disco redutivo de cores

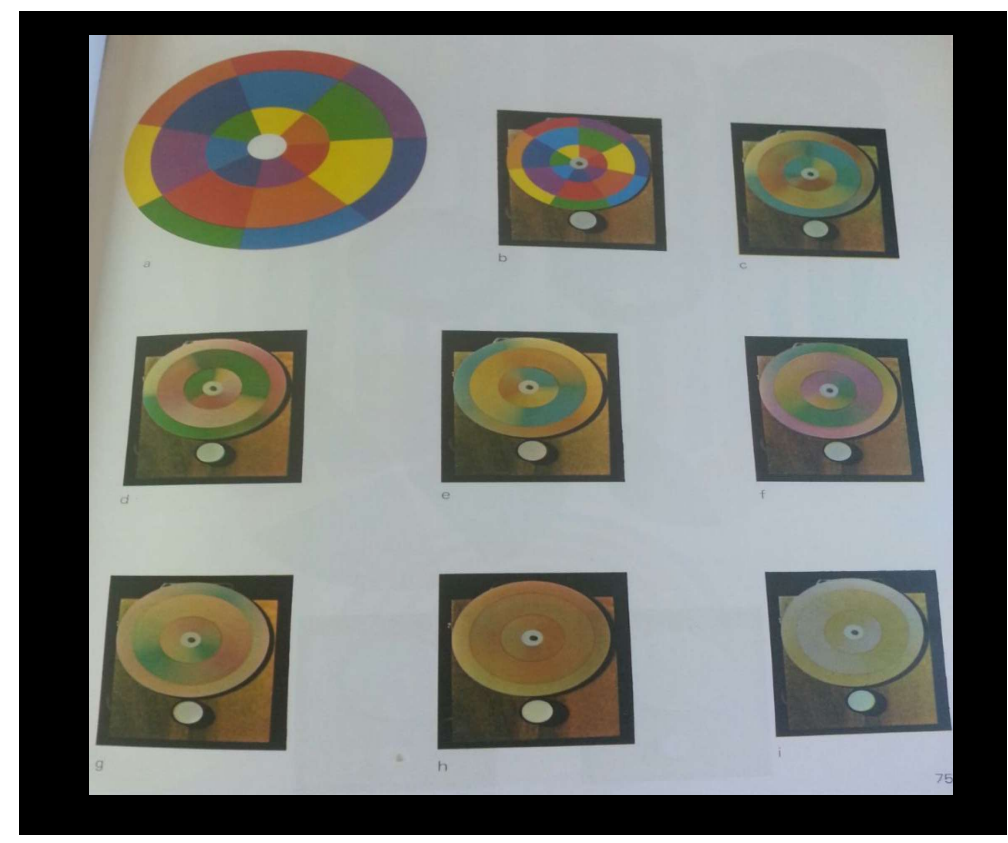

É inevitável perceber a força, a suavidade, a beleza ou a agressividade que o arranjo cromático enquanto linguagem pode imprimir ao texto. A presença das cores aliadas às formas, na obra, mais do que reforçar os valores impressos pela beleza poética do verbal, também dizem por meio da essência ou personalidade da cor, afinal:

na essência da cor encontra-se uma linguagem própria de enorme riqueza expressiva, sem qualquer conotação ou paralelo com outras formas de expressão. A poesia, o lirismo, a vibração, o arrebatamento, o telurismo, a quietude ou o silêncio da cor são mensagens especificamente visuais, podendo formular ideias e sentimentos tão precisos como a palavra ou som. (PEDROSA, 1989, p.199). 
Figura 32 - Era a Chapeuzinho Amarelo - verbal Figura 33 - Era a Chapeuzinho Amarelo -visual

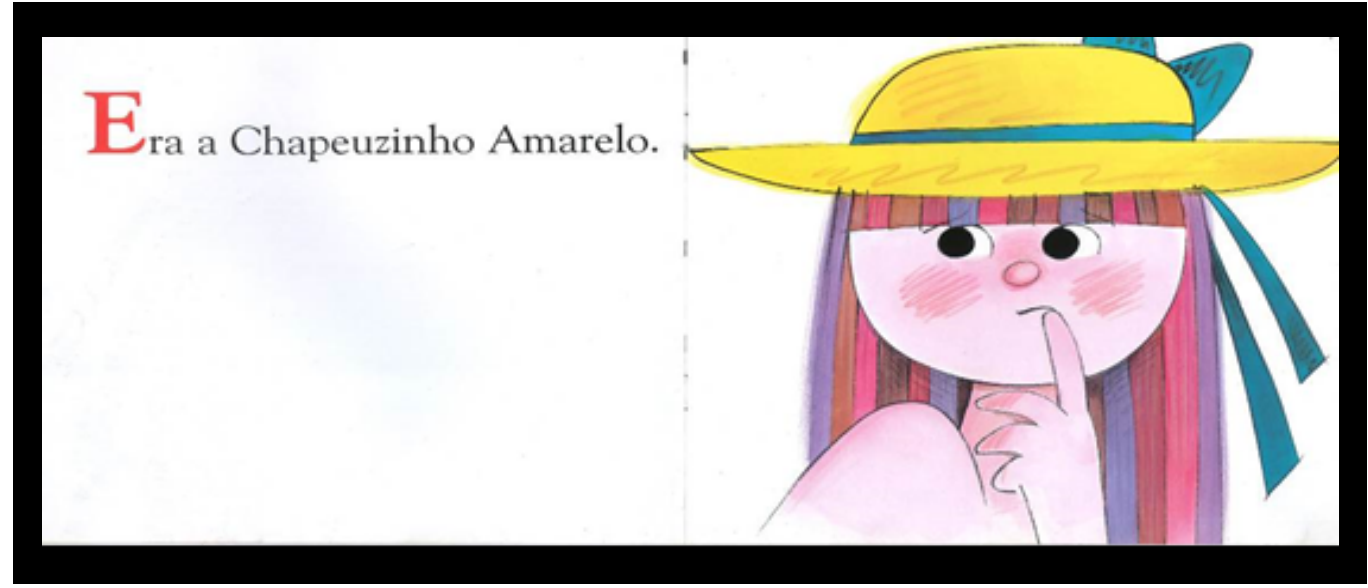

Fonte: Buarque, Ziraldo (2006)

Na sequência narrativa, o leitor se depara com a menina do chapéu amarelo que contrariamente à capa em que o título da obra, Chapeuzinho Amarelo, está escrito em vermelho, aqui, nestas páginas (figuras 32 e 33), ganha destaque com a cor preta e pelo tamanho das fontes das letras, ou seja, maior do que no restante do texto, o que de certo modo confirma a ideia de que se trata desta Chapeuzinho, a Amarelo, a de Chico Buarque e Ziraldo - e não daquela menina do chapéu vermelho, que ficou lá no passado como a cor vermelha na letra $\mathrm{E}$ do verbo era, vai indicando. Embora exista clara alusão àquela, confirmada por alguns elementos como: "lobo" e "Alemanha" que pelo modo como são organizados no texto pressupõem as histórias recolhidas da cultura oral, das narrativas populares (dos irmãos Grimm), ao mesmo tempo em que questionam sobre a existência ou verdade dessas histórias (figuras 34 e 35):

E de todos os mesmo que tinha

o mais que medonho era o medo do tal do LOBO Um LOBO que nunca se via, que morava lá pra longe, do outro lado da montanha, num buraco da Alemanha, cheio de teia de aranha, numa terra tão estranha, 
que vai ver o tal do LOBO

nem existia. (BUARQUE, ZIRALDO, 2006).

Figura 34 - Um lobo que nunca se via

Figura 35 - Vai ver o lobo nem existia

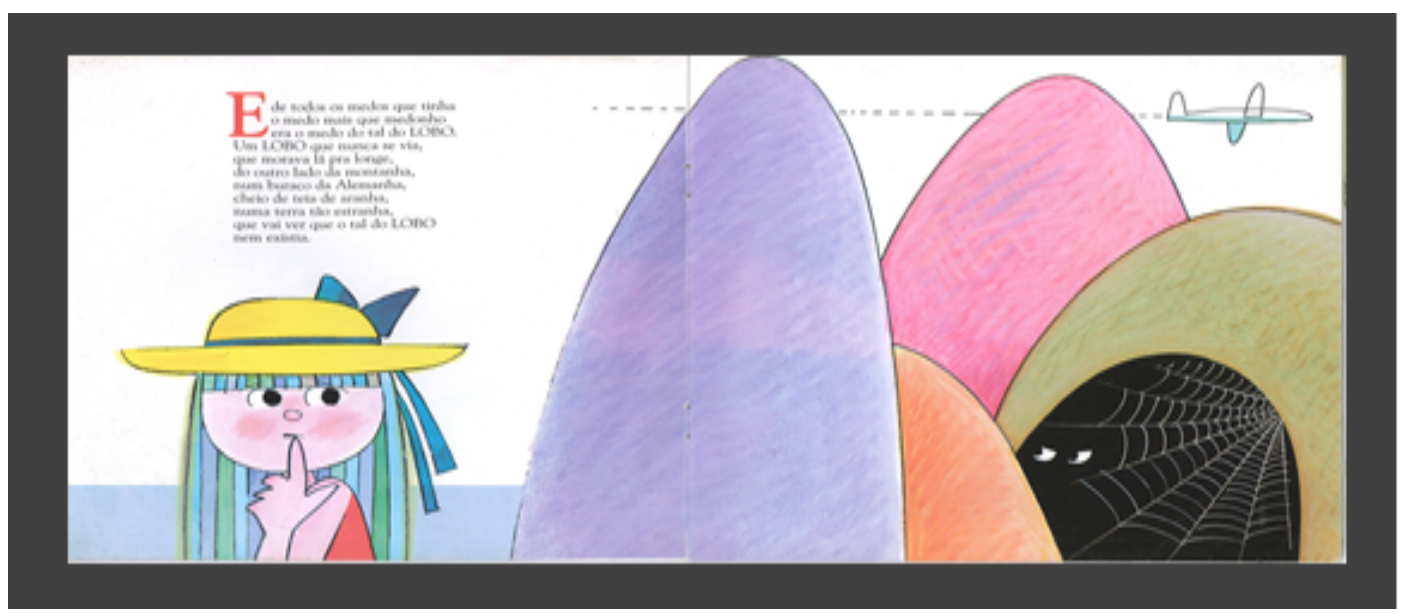

Fonte: Buarque, Ziraldo (2006)

Percebe-se, ainda, que no percurso de apresentação da personagem, o verbal da página (figura 32), à esquerda, horizontaliza-se com a imagem da página seguinte (figura 33), em que a menina anunciada, agora, aparece olhando para a esquerda, igualmente àquela "amarelada de medo", mostrada pelo verbal na página de abertura da história (figura 34), cujo olhar se dirige para a direita, corroborando uma dada construção de efeito de sentido de temor ou pavor, sobretudo por causa desse jogo com os olhos da personagem, que faz ver um deslocamento da direita para a esquerda e vice-versa, como se ela estivesse aflita ou com medo e que as figuras 34 e 35, na sequência narrativa, vão confirmar. Somam-se a isso, o dedo em riste levado à boca, mais a posição do ombro que parece encolhido.

Nesse momento da narrativa, ainda, é possível ver Chapeuzinho Amarelo com as feições e a pele do corpo rosadas (figura 33), e tal qual na primeira capa da obra usa um chapéu que pelo tom do amarelo parece querer se aproximar do observador (leitor), ainda mais pelo tamanho exagerado da aba que ultrapassa o espaço da página onde está, colocando-se em relação ao verbal (figura 43), para também confirmar a identidade do sujeito descrito pela narrativa: "Era a Chapeuzinho Amarelo". 
Dada a presença significativa da forma para a apreensão do conteúdo da obra, verifica-se o papel que ela exerce, assim como o seu grau de importância. Quanto a isso Pedrosa (1989) explica que:

Para o ato de estimulação da retina, a forma tem enorme importância. Intimamente ligada ao lado racional da construção do desenho, a ela podemos nos referir tanto como uma das partes que contornam uma área, ou como o todo da obra. Em geral, é através da forma (desenho) que a pintura se vincula a outras esferas do saber transmitindo conceitos históricos, religiosos, filosóficos, sociais, políticos, etc. (PEDROSA, 1989, p. 204).

Por esse prisma, ainda é possível verificar no texto, pelo percurso da personagem menina, que o medo metaforizado desvela questões conflituosas próprias do viver num mundo cercado por culturas, valores ou desvalores (em processo de mudanças), crenças, costumes e questões existenciais. Do temor por tudo que não se conhece, mas se pode imaginar, surge o medo do lobo que paralisa e é inevitável para que se aprenda o quanto antes a confrontá-lo, encará-lo e ver (“com os próprios olhos”) o seu tamanho, forma e cor reais (figuras 36 e 37). Decerto, essa passagem se constitui também como uma metáfora para indicar a passagem de uma fase, infância, à outra, adolescência.

Esse cenário se dá a ver como um modo de tentar conhecer a si mesmo. E, diante do contexto visual, pode-se dizer que o amarelo "é engolido pelo vermelho" que simboliza a coragem da menina diante de seu opressor, ao passo que atualiza a figura da menina do capuz vermelho resgatada nessa narrativa poética. A página dupla cria também um efeito de duplo da personagem, uma vez que ao manusear o livro (abrir e fechar) percebe-se que esse lobo é, ao mesmo tempo, a alteridade da menina. No entanto, o jogo de espelhos vai revelar mais do que isso, pois nessa relação, vê-se que, pelas ações, as personagens se diferenciam, ao mesmo tempo em que revelam suas verdadeiras identidades. Chapeuzinho Amarelo (toda escurecida pelo efeito sombra), não enxerga ou teme (ausência de olhos na imagem) mais o lobo, embora continue sendo vista por ele, de um plano superior; de cima para baixo. 
Figura 36 - O medo do medo do medo Figura 37 - Ela ficou só com o lobo

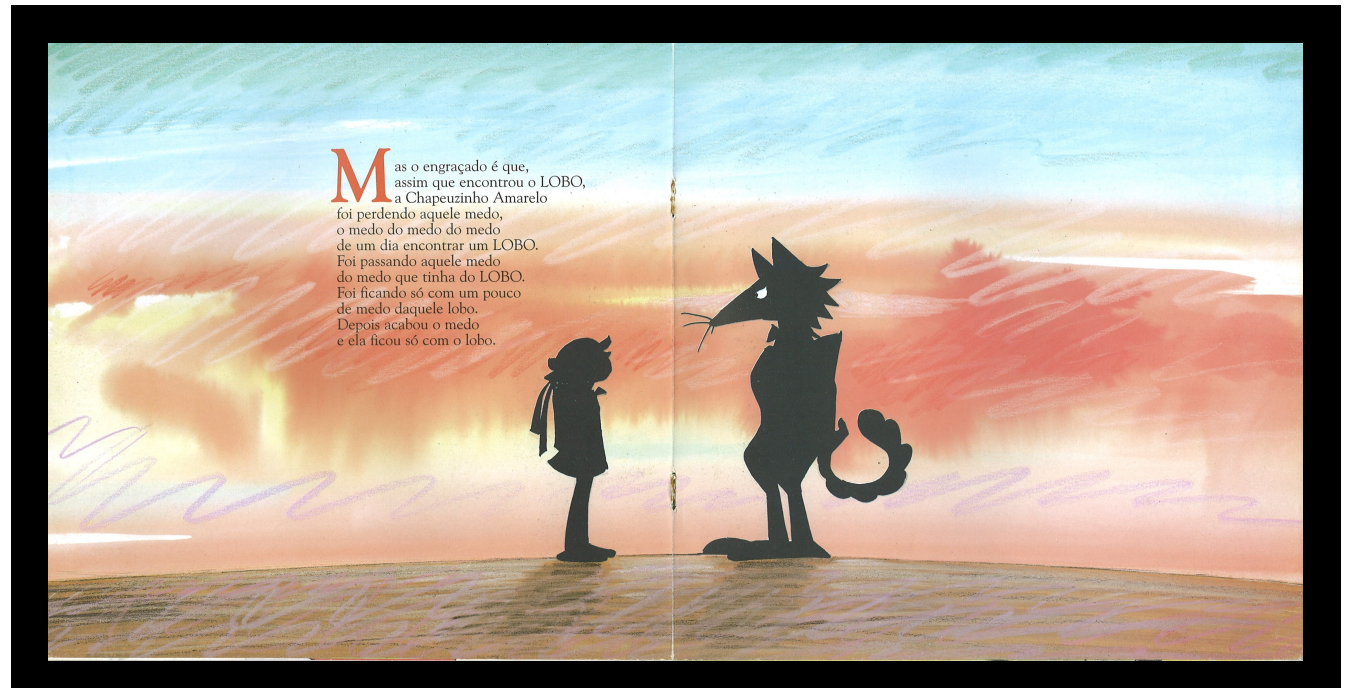

Fonte: Buarque, Ziraldo (2006)

Isso posto, o arranjo do verbal, cujo verso (figura 47): “(...) o medo do medo do medo...", pressupõe certa intenção ao confirmar o temor da menina em relação à figura do lobo, recuperando, por meio da alusão, os versos do texto musical Língua, de Caetano Veloso: "Sejamos o lobo do lobo do homem/lobo do lobo do homem.", os quais constroem a ideia de ruptura do lastro com Portugal em prol da construção de muito mais do que uma identidade linguística brasileira, mas uma identidade enquanto sujeitos ou, por assim dizer, remetem à libertação do opressor.

Nesse tocante, Costa (2009, p. 18) enfatiza que: "No Brasil, a questão identitária foi colocada, sobretudo, a partir do século XIX, com a busca romântica que nasce do conflito de já não querer ser português, quando se busca romper o 'vínculo placentário' de que fala Antonio Candido". Do mesmo modo, Zilberman destaca:

Vale lembrar, ainda, que desde o século XIX os livros de leitura indicados pela Escola incluíam trechos importantes de autores consagrados do passado literário, no entanto não faziam a distinção de autores de Portugal e do Brasil. Tal diferenciação só ocorreu, de acordo com Ziberman, após o modernismo: "A diferenciação entre nacionais e estrangeiros começa a se acentuar após o modernismo, na década de 20 , de modo que os livros didáticos, que substituíram as seletas utilizadas até então, passaram a 
incorporar maior quantidade de textos brasileiros que portugueses. (...)" (ZILBERMAN, 2014, p. 47).

Dito isso, a língua enquanto identidade passa a ser o lugar onde o homem se assume como indivíduo e assume também os valores do mundo em que lhe cabe viver, assim como seus signos e símbolos na construção da realidade ou na desconstrução dela e, por isso, não é de se estranhar que Chapeuzinho Amarelo, para driblar tudo que lhe aflige, ressemantize o valor dos signos verbais - alterando a forma padrão da escrita das palavras (rompendo com o código convencionado), cujo novo arranjo não representa mais perigo ou opressão (figuras 38 e 39), uma vez que, agora, passam a não significar o nome de seres pavorosos, mas organizam para ela um novo espaço de ações ou um espaço onde a menina pode circular livremente: “(...) o raio virou orrái,/barata é tabará,/a bruxa virou xabru/e o diabo é bodiá." E assim, outros amigos foram surgindo (figuras 40 e 41) como, por exemplo, o dragão - o "Gãodra", a coruja - a "Jacoru”, o tubarão - o "Barão-Tu", o bicho papão - o "Pão Bichôpa" e todos os "trosmons".

É interessante observar esse movimento de desconstrução do medo, também, a partir da representação, dada a ver pela linguagem visual, tanto dos seres renomeados, quanto da própria Chapeuzinho Amarelo. Nesse tocante, a visualidade mostra a menina de braços abertos, com um sorriso incontido, dirigindo-se ao leitor com uma expressão no rosto que denota sensação de liberdade, bem diferente de quando surgiu na primeira página do livro. Diante disso, é importante pensar que as crises existenciais são temas antigos, embora nem sempre tenham encontrado lugar para diálogo no texto literário destinado à criança. 
Figura 38 - Liberdade

Figura 39 - Fim do medo

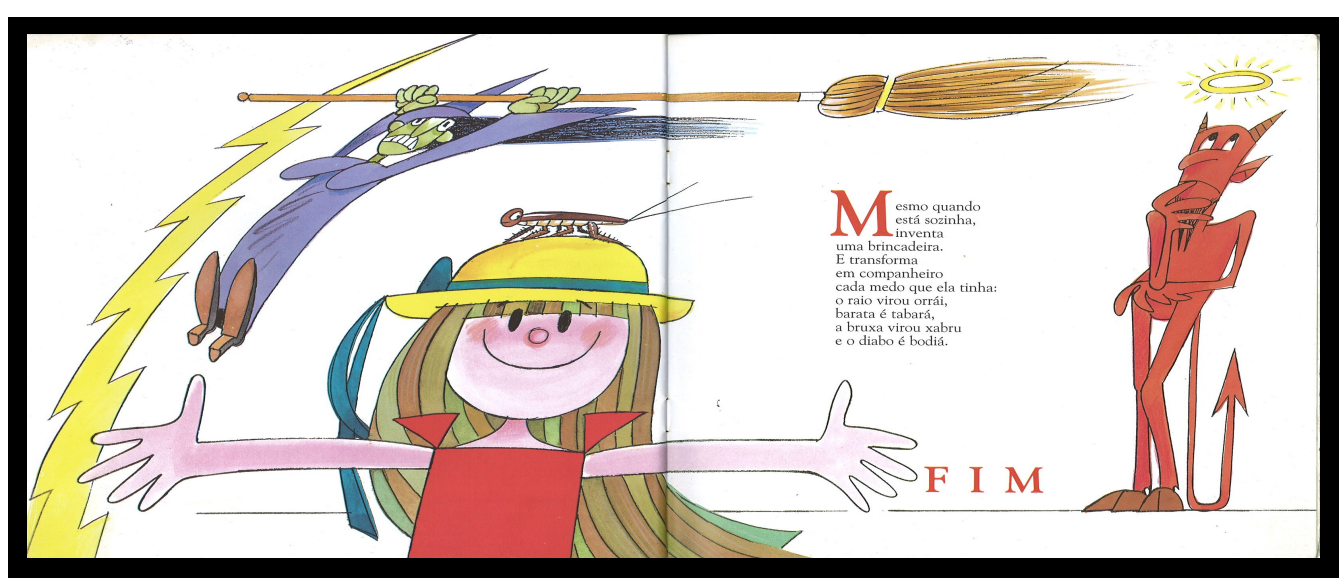

Fonte: Buarque, Ziraldo (2006)

Figura 40 - Outros companheiros

Figura 41 - Invenção e brincadeira

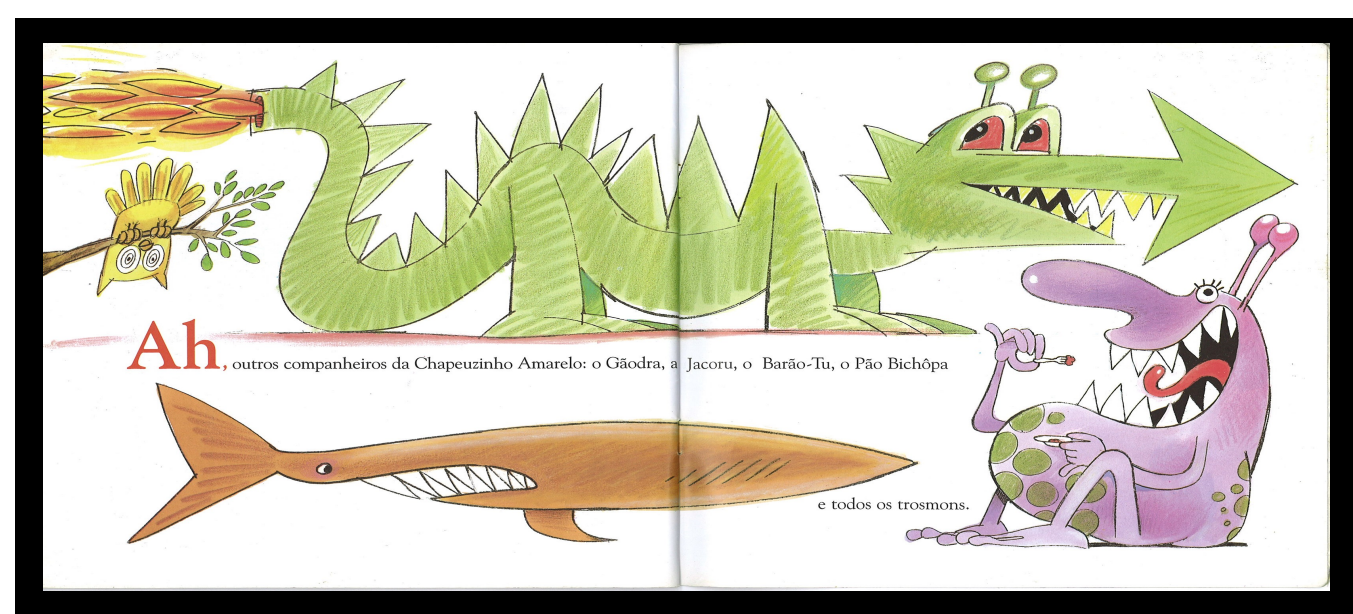

Fonte: Buarque, Ziraldo (2006)

Com efeito, diante do posto, pode-se pensar na linguagem visual (figuras $42 \mathrm{e}$ 43) em que o lobo aparece como reflexo ou projeção que sai da própria menina (desdobramento do outro eu; alteridade) ou uma espécie de efeito sombra que mostra um tipo de sujeito capaz de criar seus próprios medos, mas que deve devorá-los para não ser devorado. De certa maneira, essa representação remete, de certa maneira, a Thomas Hobbes em Leviatã (1988): "O homem é o lobo do homem", ao passo que, ainda, reitera os valores de liberdade discutidos anteriormente. 
Figura 42 - Um lobo que não existia

...Figura 43 - Alteridade

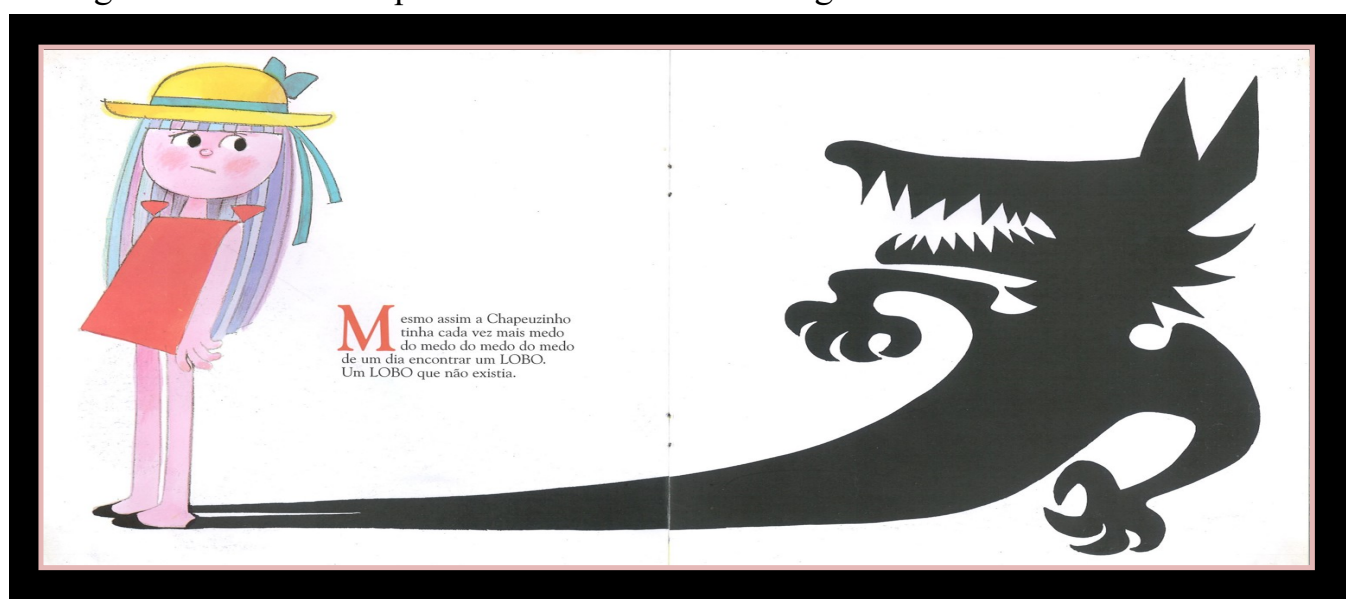

Fonte: Buarque, Ziraldo (2006)

Não obstante a tudo isso, a nova organização da obra Chapeuzinho Amarelo prima por uma riqueza de linguagem capaz de criar efeitos de sentido em que se pode ver, inclusive, uma forte referência ao movimento antropofágico brasileiro, marcado pelo manifesto de Oswald de Andrade. Nesse movimento as culturas, as manifestações e os estilos seriam digeridos e transformados a título de forjar-se uma libertadora identidade brasileira. Assim:

Sabemos, por último, que a resposta, com êxito, à questão da identidade se traduz sempre numa reinterpretação fundadora que converte o déficit de sentido da pergunta no excesso de sentido da reposta. Fá-lo, instaurando um começo radical que combina fulgurantemente o próprio e o alheio, o individual e o coletivo, a tradição e a modernidade. (...) O caso de Oswald de Andrade é, a este propósito, particularmente significativo. Ao declarar os poemas reunidos na coletânea Pau-Brasil, publicada em 1924, como tendo sido escritos "por ocasião da descoberta do Brasil", Andrade propõe-nos um começo radical que em vez de excluir, devora canibalisticamente o tempo que o precede, seja ele o tempo falsamente primordial do nativismo, ou o tempo falsamente universal do eurocentrismo. Esta voracidade inicial e iniciática funda um novo e mais amplo horizonte de reflexividade, de diversidade e de diálogo donde é possível ver a diferença abissal entre a macumba para turistas e a tolerância racial. Acima de tudo, Oswald de Andrade sabe que a única verdadeira descoberta é a autodescoberta e que esta implica presentificar o outro e conhecer a posição de poder a partir do qual é possível a apropriação seletiva e transformadora dele (Andrade, 1990). (SANTOS, 2013, p.168). 
As considerações de Santos sobre a autodescoberta como transformadora é cara à literatura infantil e juvenil, sobretudo pelas novas feições que começam a ser dadas ao texto da modernidade e que irão refletir profundas mudanças, marcadas por uma explosão de multilinguagem e, consequentemente, pelo novo cenário que se apresenta.

Nesse período, artistas plásticos se unem aos artistas da palavra na construção da unidade de sentido do texto da literatura infantil, promovendo um valor diferente às narrativas, que passam a instigar a imaginação por meio da percepção das novas maneiras de se contar histórias para crianças e jovens. Logo:

[...] Aceita-se assim que uma invenção também é circunscrita no tempo: ela será substituída por outra, mais engenhosa, mais moderna. Essa é uma palavra cara às vanguardas do século XX, que defendem o constante produzir do novo como um valor. (PERRONE-MOISÉS, 1990, p.101).

Com isso, percebe-se que a soma dessas linguagens é capaz de gerar, a partir de uma dada "reinvenção", efeitos de novidade no texto consagrado. Nessa projeção, vê-se um lobo travestido com os ares da modernidade representando, por conseguinte, uma espécie de arlequim (figuras 44 e 45), anunciado por cores e formas tais quais as vistas na capa da obra Pauliceia desvairada, de Mario de Andrade (figura 46).

Figura 44 - O lobo ficou chateado Figura 45 - "Pô"

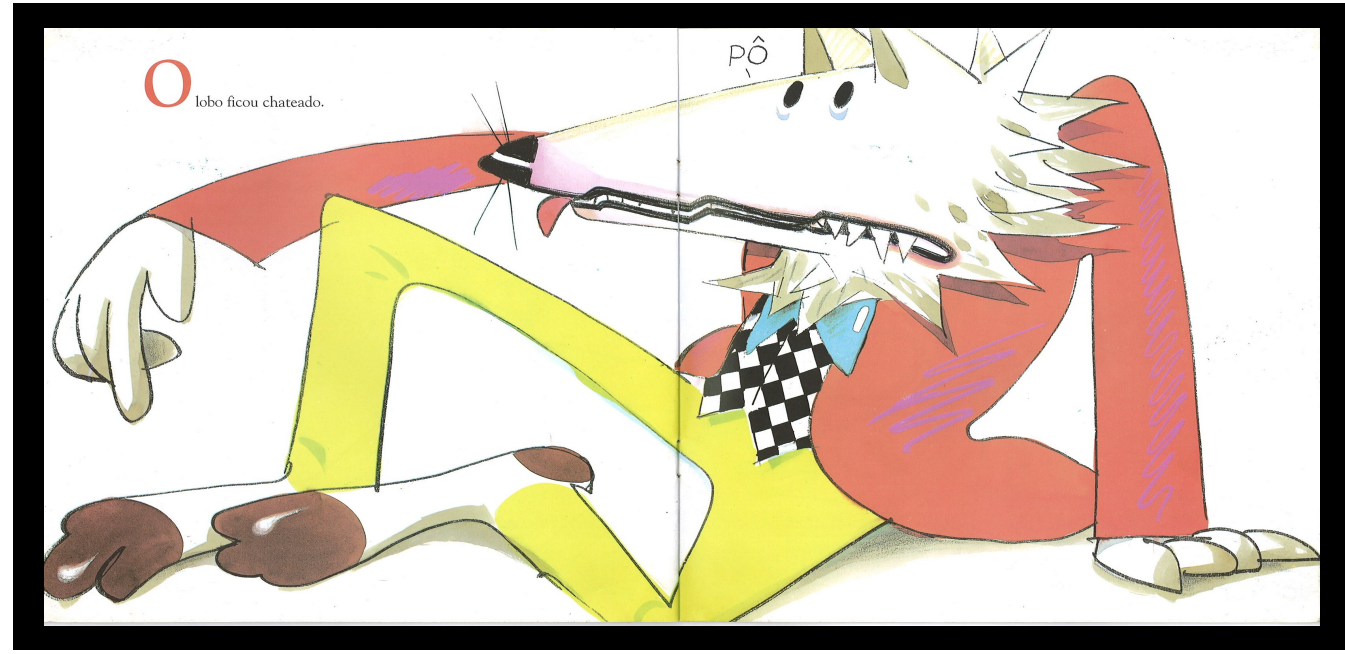

Fonte: Buarque, Ziraldo (2006) 
Figura 46 - Pauliceia desvairada

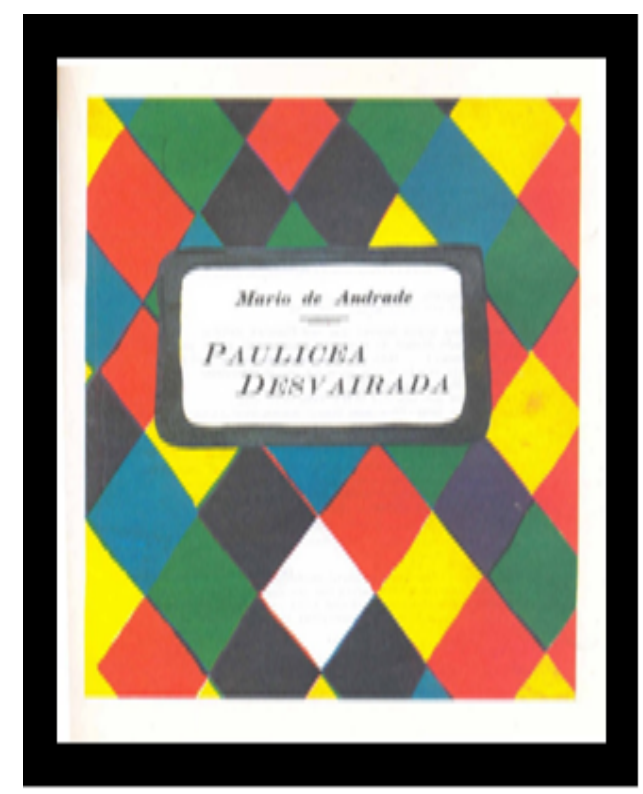

Fonte: Andrade (1922)

Figura 47 - Figura e fundo

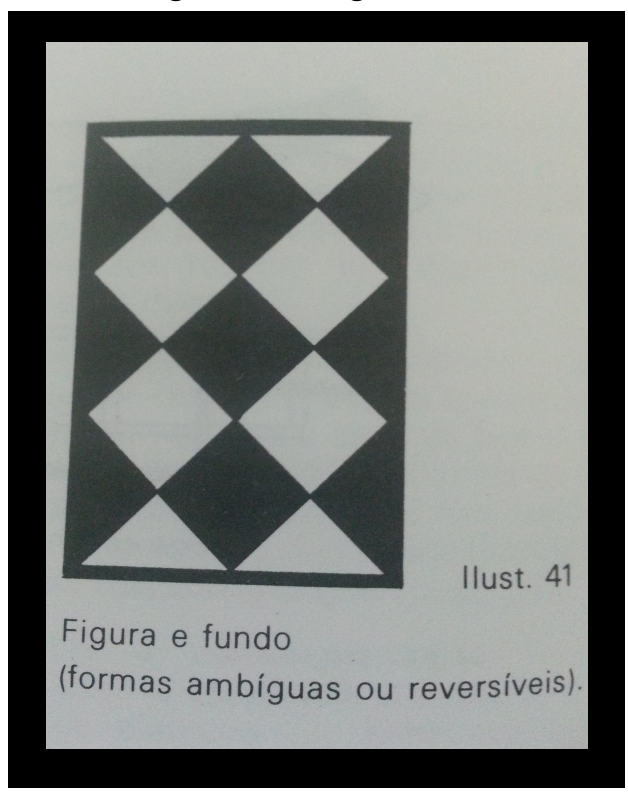

Fonte: Pedrosa (1989)

A presença dessa figura de palhaço estilizado é referência constante também em obras de outros autores e assume conotações diferentes em que ora pode representar o 
desvairismo atribuído à cidade de São Paulo, ora pode sincretizar o lírico e o dramático ao patético. No caso, ainda, do lobo arlequinal, ilustrado por Ziraldo, este é visualizado por meio de arranjos cromáticos e formas ambíguas ou reversíveis que dão a ver uma tridimensionalidade, a partir do jogo figura e fundo (figura 47), em preto e branco, construído com figuras geométricas em formato de losangos que compõem a peça interna do vestuário do sujeito lobo. Nesse espaço de hipertextualidades e efeitos polifônicos destaca-se também o efeito do pastiche que o texto visual apresenta. E, que de acordo com Koch, Bentes e Cavalcante:

[...] se constrói pela imitação de um estilo, isto é, não pela repetição das características formais de um gênero, como ocorre com os textos parodiados, mas pelo arremedo do estilo de um autor, dos traços de sua autoria. Como Piègay-Gros, a função do pastiche pode ser a de exorcizar o estilo de um autor, com propósitos críticos e/ou humorísticos, mas pode também atender a objetivos outros. Em textos literários, o pastiche às vezes é utilizado também para render homenagem ao autor do texto-fonte. (KOCH; BENTES; CAVALCANTE, 2012, p. 141).

É possível perceber a presença do trabalho com figura e fundo também no diálogo entre Chapeuzinho Amarelo e o lobo (balão de fala do lobo, cujas palavras em letras de fonte grande e cor preta se destacam no fundo todo branco), sequência narrativa (figuras 48 e 49), via ilustração do momento em que a menina, já desfeita do medo por completo que tinha do lobo, ri da sua figura patética que, sem êxito, tenta reafirmar sua condição de mau, literalmente, no grito: "EU SOU UM LOBO!" (letras em caixa alta no balão de linha contínua - recurso emprestado das histórias em quadrinhos -, deixando ver o efeito de pontas, como reforço do grito, na boca do lobo que corrobora esta função, portanto).

Do mesmo modo, observa-se que o lobo, agora, ocupa o lugar do oprimido (na página - lado esquerdo), em que antes aparecia a menina, enquanto ela passa a ser mostrada no lugar do opressor (na página - lado direito), onde se via o lobo mau. Assim, portanto, ocorre uma inversão de lugares físicos que transcendem para o espaço do psicológico e, consequentemente, modificam as ações e os estados dos sujeitos menina e lobo.

A desconstrução dos papéis sociais desses sujeitos (lobo - homem x menina lobo) ganha contorno expressivo por meio do verbal e do visual, sobretudo porque o lobo 
vira bolo (figuras 50 e 51), artimanha da oralidade - LOBO/BOLO, passando à condição definitiva de oprimido (figuras 52 e 53): “(...) tremendo que nem pudim,/com medo da Chapeuzim./Com medo de ser comido/com vela e tudo, inteirim.”, enquanto Chapeuzinho, nessa relação, firma-se como "sujeito opressor". Embora, a menina se sobressaia por romper com a tradição e não repetir o desfecho da narrativa Chapeuzinho Vermelho, no conto de Perrault, pois diferentemente daquela, não ocorrerá com o lobo o mesmo que acontecera a Chapeuzinho e sua avó (figura): “Chapeuzinho não comeu/aquele bolo de lobo,/porque sempre preferiu/de chocolate. (...)".

Figuras 48 - Eu sou um lobo

Figura 49 - Mas a Chapeuzinho, nada

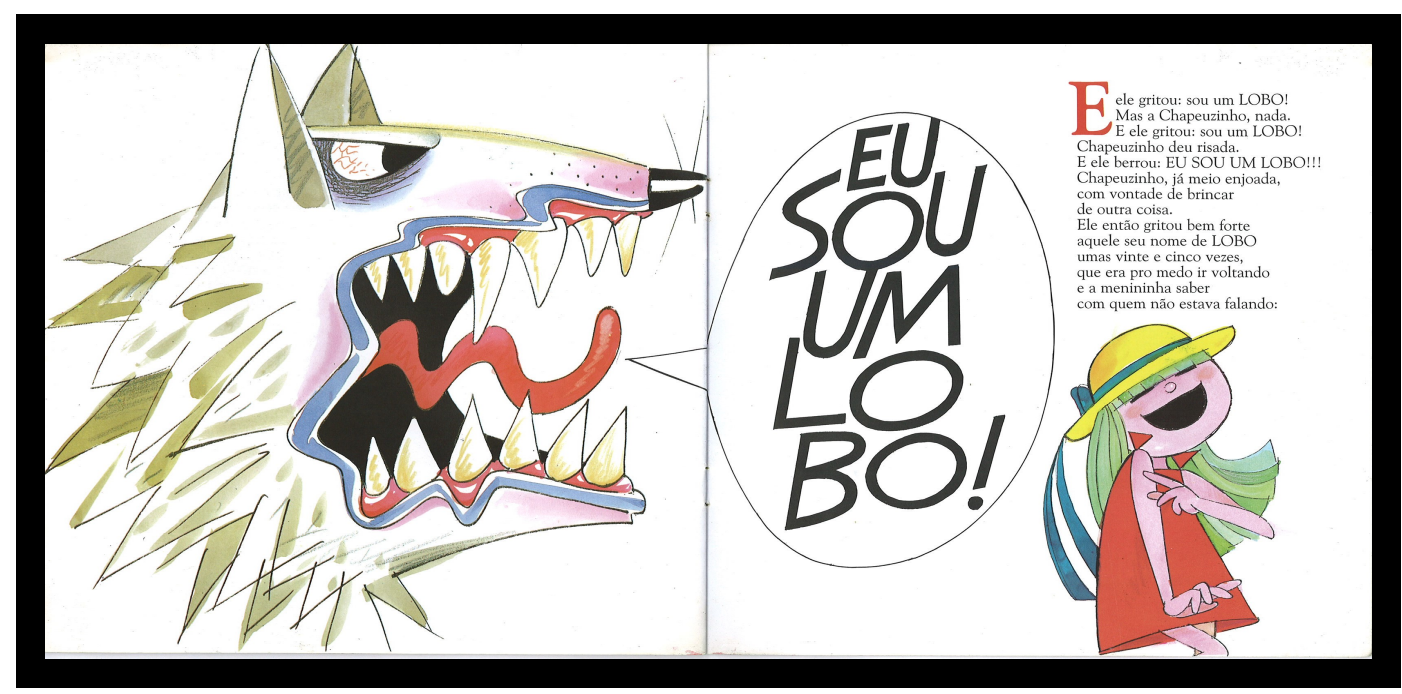

Fonte: Buarque, Ziraldo (2006) 
Figura 50 - Lobo, bolo Figura -51 Bolo, lobo

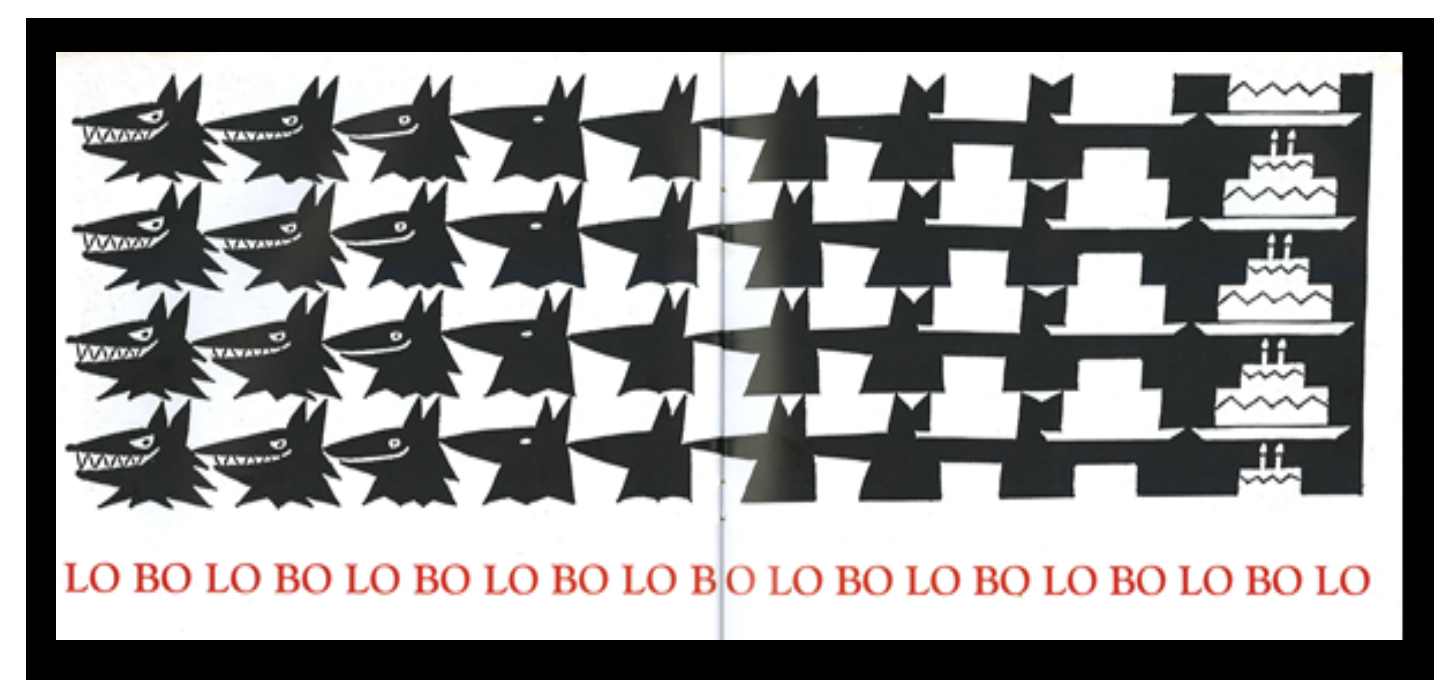

Fonte: Buarque, Ziraldo (2006)

Figura 52 - Já não era mais um lobo

Figura 53 - Bolo de lobo fofo

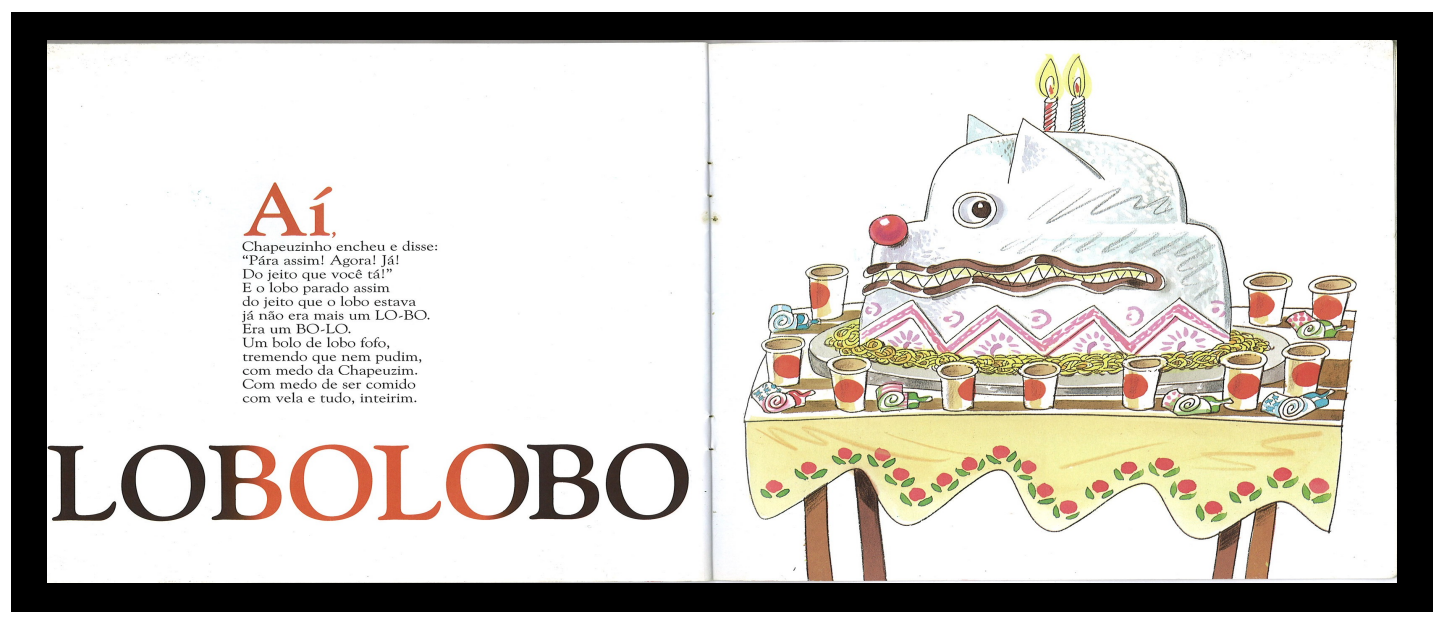

Fonte: Buarque, Ziraldo (2006)

\subsection{Clássico atualizado: a história (não) se repete}

A atualização de uma nova fase de Perrault foi responsável por fazer com que o autor abandonasse seus trabalhos em versos e organizasse as narrativas em prosa por meio de uma linguagem clara e precisa, o que se por um lado não deu a ele o reconhecimento 
como poeta clássico pela Academia Francesa da qual passou a fazer parte em 1671, por outro fez dele o responsável por uma literatura popular que, embora desvalorizada pela estética de seu tempo, foi capaz de consagrá-lo como autor da literatura infantil e um dos maiores sucessos para a infância.

Esse reconhecimento, portanto, se deu a partir da reunião de oito contos populares, na primeira compilação de narrativas para publicação: A Bela Adormecida no Bosque - La Belle au Bois Dormant; Chapeuzinho Vermelho - Le Petit Chaperon Rouge; O Barba Azul - La Barbe-bleue; O Gato de Botas - Le maître Chat ou Le Chat Botté; As fadas - Les Fées; A Gata Boralheira ou Cinderela - Cendrillon ou La Petite Pantoufle de Verre; Henrique, O Topetudo - Riquete à La Houppe; O Pequeno Polegar - Le Petit Poucet, reunião de contos à qual, posteriormente, acrescentaria mais três: A Pele de Asno, Os Desejos Ridículos e Grisélidis, contabilizando um número de onze histórias que ganharam o mundo.

Perrault escreveu Os contos da Mamãe Gansa numa época em que não existia o gênero literatura infantil, mas ainda assim suas narrativas foram se imortalizando como leitura essencial, uma vez que foram eleitas misteriosamente, primeiro pelas crianças francesas e depois pelas crianças de todo o mundo. Esse processo inclui as crianças brasileiras que, igualmente às francesas, se mostraram fascinadas por essa obra desde a mais tenra idade, ou desde o berço como atesta Coelho ao mencionar que $(2010$, p. 86): " $O$ Pequeno Polegar, A Bela Adormecida, O Gato de Botas... são estórias que fazem parte da vida de toda criança, mesmo antes de aprenderem a ler... e que lhes são tão familiares quanto as cantigas de ninar com que foram embaladas...”.

Marc Soriano em sua tese, Les contes de Perrault, cultura savante et traditions populares, realizada na Universidade de Bordeaux sobre esse material de Perrault, considera a obra como um lugar de "enigmas e contradições". Contudo, é ele próprio quem vai afirmar a validade da obra como clássico, pois atesta que Os contos da Mamãe Gansa é o único livro que mesmo não sendo lido na escola, cada criança francesa conhece de cor, ainda que não saiba ler e também o único clássico que essa criança guardará na memória, ainda que não o leia mais ou mesmo que não goste de ler. Acerca disso, Coelho (2010) observa que qualquer análise de ordem psicanalítica realizada pelo professor e pesquisador francês sobre o assunto passa a ser secundária diante da grande questão, importante também 
para nossa pesquisa, que é a de se observar um percurso literário que, mesmo enigmático e paradoxal na sua gênese, orienta para um ponto a ser perseguido: a transformação da literatura para crianças e a atualização de seus textos como lugares possíveis para diferentes apreensões sobre diferentes sociedades.

A "Querela dos Antigos e Modernos²" é, sem dúvida, um divisor importante na vida literária de Perrault, pois é em função dessa polêmica e durante o tempo em que ela permaneceu que ele produz os contos que o iriam imortalizar. Nesse recorte, residem aspectos de produção do autor, numa dada temporalidade, que são significativos para nossas análises, uma vez que Perrault, organiza no século XVII textos que refletem não só um tempo passado, mas um posicionamento literário capaz de projetar outras sociedades e seus conflitos. A figura da mulher, nesse tocante, é central para a discussão que seguirá. No entanto, mesmo diante de tal contexto marcados em seus escritos, não caberá atestar Perrault como "defensor das causas feministas", mas verificar uma participação importante em que, certamente, suas personagens femininas foram significativas como manifestações de sujeitos fragilizados em seus contos populares.

Assim, citam-se três eventos, dos seis relacionados por Coelho (2010) como pontos principais da "Querela" e que colocam o papel social da mulher em discussão nas narrativas infantis:

Perrault era um frequentador assíduo dos "Salões" das "preciosas" onde uma das leituras prediletas era a dos caudalosos "romances preciosos", cuja matéria exuberante, fantasista e sentimental estava mais perto da "desordem" do pensamento popular do que da "ordem clássica". E mais, como o eixo de tais romances era o Amor, obviamente a Mulher o elemento central das atrações.

Sabe-se também que a sobrinha de Perrault, Mlle. L'Héritier atraiu-o para a "causa feminista", na defesa dos direitos intelectuais das mulheres, tão legítimo quanto os dos homens. (Tão ponderável se revelava a produção literária feminina e a atuação de várias mulheres na área da cultura que suscitaram muitas obras de ataque, inclusive de grandes escritores, como

\footnotetext{
${ }^{22}$ De acordo com Coelho (2010, p. 87): "Por ocasião da revogação do Édito de Nantes por Luís XIV, Perrault escreve Saint-Paulin (1686), epopeia cristã que se apresentava como exemplo de uma 'arte moral', tal como seu autor julgava necessário no momento. Logo a seguir, faz ler em sessão da Academia Francesa o poema 'O século de Luís, o Grande', contra Racine e Boileau, partidários dos Antigos, e provoca a polêmica que fica conhecida como 'Querela dos Antigos e Modernos' e que marca a crise do classicismo. Obrigado a justificar sua posição de 'moderno' e a provar que conhecia perfeitamente os 'antigos', Perrault escreve Paralelos (4 vols. publicados entre 16881697)."
} 
Molière, que as combateu ou ridicularizou em suas comédias Écoles de Femmes, Les Precieuses Ridicules e Les Femmes Savantes, embora nesta última seu tom sarcástico já tenha diminuído).

Foi exatamente um desses ataques o motivo aparente que levou Perrault a escrever seu primeiro conto. Sabedor de que Boileau (seu mais sério opositor na "Querela") estava escrevendo sua Sátira $x$ Contra as Mulheres, Perrault se revolta e, escolhendo um dos mais antigos "fabliaux" do folclore francês, escreve A Marquesa de Salusses ou a Paciência de Grisélidis. Antes mesmo de Boileau apresenta sua Sátira ao público, Perrault lê, na Academia Francesa, esse conto em versos onde faz o elogio da felicidade e da paciência das mulheres. (COELHO, 2010, p. 88).

Destaca-se, nessa relação, que uma dessas mulheres, dos Salões das preciosas, a jovem baronesa Mme. D’Aulnoy, foi a responsável por colocar em moda os contos de fadas na corte francesa. Em 1690, em um de seus relatos de viagem, Relação da Viagem à Espanha, que fizera grandioso sucesso, já havia um episódio em que aparecia a figura da fada. Passados cinco anos desse evento, a escritora inicia o trajeto da publicação de contos maravilhosos que, indo de encontro ao modelo clássico e, consequentemente, ao modelo dos antigos greco-latinos, lançavam a moda das fadas entre os adultos.

Pode-se pensar, diante disso, em dois eventos importantes que colaboraram para o processo de redescoberta das narrativas populares resgatadas por Perrault: a substituição dos valores clássicos pelos populares e a causa feminista presente nas narrativas. Certamente, tais situações devem ser consideradas como questões que podem ter influenciado a percepção do autor para uma literatura há muito esquecida.

Isso posto, parece inegável o posicionamento de Perrault sobre o papel da mulher na sociedade do século XVII, ao mesmo tempo em que se verificam projeções deste nas sociedades e literaturas contemporâneas. Tais projeções são, de muitas maneiras, visíveis na obra contemporânea escolhida, Chapeuzinho Amarelo (já vista sob o foco do arranjo verbo-visual), como obra-matriz para as análises adiante e, inevitavelmente, para os desencadeamentos dados a partir dos diálogos intertextuais que ela retoma com Chapeuzinho Vermelho, trazida à tona, sobretudo pela força capaz de suscitar velhos e novos contextos sociais.

E, mesmo diante de tantas contradições, como se observou e observa ainda hoje no percurso de evolução da literatura infantil, cabe rever posicionamentos como o de 
Rousseau, que marcou a Escola Nova do século XIX com sua influência mais ampla (doutrina naturalista), ainda que diante de alguns "defeitos de base", de acordo com Coelho (2010, p.133): “como a ênfase dada à educação do corpo e dos sentidos, em detrimento da educação da inteligência, que só viria depois dos 12 anos."

Da mesma forma, no que diz respeito à educação feminina, Rousseau também confirma o silenciamento da mulher, uma vez que cede voz a um sistema patriarcal, que dadas as diferenças no tempo, continua como herança para a contemporaneidade. $\mathrm{O}$ autor, em seu Livro V de Emílio, diz:

Toda educação das mulheres deve ser relativa aos homens. Agradá-los, ser-lhes úteis, se fazerem amar e honrar por eles, educar os jovens, cuidar dos grandes, aconselhá-los, consolá-los, tornar-lhes a vida agradável e doce: eis os deveres das mulheres em todos os tempos, e o que devemos ensinar-lhes desde a infância. (ROUSSEAU, s/d, p.77).

Sobre isso, Coelho se manifesta de modo enfático a respeito de Rousseau e da criação de um modelo de mulher que a educação naturalista levaria a formar:

Obviamente, esse princípio de base, assimilado pelo Romantismo e perpetuado pelos costumes e pela pedagogia até o nosso século, explica a atitude que as meninas assumem nas estórias e também a imagem que a literatura tradicional (e muita literatura atual) oferece às mulheres, como um modelo a ser imitado. Substituir essa imagem por outra mais condizente com os novos tempos e as novas conquistas está sendo o árduo trabalho de todos os espíritos criadores de nossos dias (e das mulheres conscientizadas). (COELHO, 2010. p. 134).

De modo particular, observam-se os reflexos dessa movimentação nos textos da literatura infantil e juvenil e percebe-se uma grande oscilação entre o desejo de manter o romantismo do passado atrelado à perpetuação de um tipo de figura feminina submissa e a substituição dessa imagem por outra capaz de representar todas as significativas reivindicações femininas no curso da história. Tal valor, acredita-se, está numa revisão urgente da descoberta das histórias de gente sem história. E antes de se verificar essa situação nos textos, selecionados para análises, é preciso entender, do ponto de vista da própria História, via historiografia, o papel da mulher na nova sociedade. 
4.2.1 Substituição de imagem: novos olhares sobre o passado

É, de fato, imprescindível que se reveja a situação histórica sobre o passado da condição feminina, para que se entenda a evolução que a literatura atual cria como imagem atualizada do passado e as conquistas que refletem a menina e a mulher do novo tempo. E, dessa maneira, na atualidade se discuta a questão de gênero, que de muitas formas é manifestada nos textos do passado e nos do presente, como se mostra nas discussões que seguem.

Quando se fala de categoria-gênero é importante situar uma temporalidade cuja época de ocorrência nos coloca frente a um contexto de grandes questionamentos e complexidades que a contemporaneidade vem retomando, com novo enfoque nas pesquisas científicas, a partir de testemunhos de mulheres e do desafio da invisibilidade delas no passado. É dessa maneira que se retoma a década de 70 como um momento de transformações significativas para as discussões sobre a mulher e a abordagem de gênero e seus desdobramentos históricos, políticos e sociais.

Sobretudo, porque os estudos atuais apontam a importância do questionamento da universalidade sobre o discurso histórico e a necessidade de se reacender a memória a partir da pluralidade de possibilidades de olhares sobre o passado. Essa descentralização dos sujeitos históricos, de acordo com Matos (2000, p.11), permitiu: “(...) a descoberta das 'histórias de gente sem história', procurando articular experiências e aspirações de agentes aos quais se negou lugar e voz dentro do discurso histórico convencional."

Nessa perspectiva, a revisão do que se propunha a historiografia do passado, agora revela, além da exclusão feminina atrelada a um discurso universal masculino, novos perfis, novas histórias e outras falas desse grupo feminino. As mudanças incorporadas ao modo de pensar a mulher e a abordagem de gênero ganham expansão, via estudos, que mostram um quadro mais nítido da história e da transformação sofrida nos últimos tempos.

Além disso, o dito novo olhar sobre o passado coloca em xeque os paradigmas tradicionais, exigindo uma revisão do modo de articulação de seus instrumentos de pesquisa e consequentemente a consideração de múltiplas questões centradas no presente. $\mathrm{E}$ é a partir dessa "crise de identidade" da história que se renovam os valores, instaurando a 
procura de outras histórias capazes de fortalecer a ampliação do saber histórico sobre as universalidades, permitindo a descoberta do outro - as mulheres -, entre tantos sujeitos excluídos da História e da sociedade.

Do mesmo modo, é a crescente presença das mulheres nos escritos literários e acadêmicos que abre caminho à visibilidade feminina e consagra a conquista de novos espaços. Isso levando-se em conta uma presença maior das mulheres no mercado de trabalho (principalmente em núcleos de pesquisa e estudo nas universidades), na luta pela igualdade de direitos e liberdade e, também, pela conquista do espaço público a partir da autoafirmação dos movimentos feministas vigentes na década de $70^{23}$, quando a $\mathrm{ONU}$ instituiu o Ano Internacional da Mulher.

E mesmo em meio ao quadro desfavorável dos governos militares, questões referentes à mulher ganharam novo fôlego. Assim, temas importantes como a violência sexual, a contracepção, o aborto, a dupla jornada de trabalho e o direito à cidadania, à identidade emergiram com certa força. Além disso:

Somaram-se a essa luta outros canais de participação da mulher, sobretudo na forma dos movimentos por melhores condições de vida, ocupando espaço social e político a partir da segunda metade da década de 70. No âmbito dos bairros, creches, escolas e principalmente nas igrejas, a presença feminina foi marcante, reivindicando condições de saúde, educação, saneamento básico, habitação (carências de uma população marginalizada no processo de urbanização), além da luta pela anistia. (MATOS, 2000, p.10).

É fato, que diante de tudo isso, os espaços tradicionais de expressão política se fechavam para esses acontecimentos e as mulheres se organizavam em outras frentes alternativas de atuação que as constituía como sujeitos coletivos e políticos. Nesse

\footnotetext{
${ }^{23}$ Isso considerando-se, ainda, os longínquos antecedentes das lutas femininas apontados por Matos (2000). Desde os finais do século passado, sinhás e mulheres de elites publicaram jornais femininos nos quais suas reivindicações concentraram-se, sobretudo, em dois pontos: a educação feminina e o direito de voto das mulheres. Desde os anos 20, mulheres como Bertha Lutz, $\mathrm{M}^{\mathrm{a}}$ Lacerda de Moura e Eugênia Cobra lutaram pela emancipação feminina, paralelamente às lutas de mulheres operárias, sobremodo anarquistas. Temos aí claramente definidas as duas vertentes do feminismo: a liberal e a libertária.
} 
contexto, novas tendências de abordagem se ampliaram em função do caráter dinâmico das relações sociais e modificaram os paradigmas históricos:

Assim, na década de 70, as mulheres 'entraram em cena' e se tornaram visíveis na sociedade e na academia, na qual os estudos sobre a mulher se encontravam marginalizados na maior parte da produção e na documentação oficial. Isso instigou os interessados na reconstrução das experiências, vidas e expectativas das mulheres nas sociedades passadas, descobrindo-as como sujeitos da história e objeto de estudo. (MATOS, 2000, p. 10).

A redescoberta da mulher como sujeito político no âmbito do cotidiano instituiu, sem dúvida, um novo questionamento sobre as transformações da sociedade e o papel da mulher nesse lugar do ser. O que de acordo com Matos (2000, p.11), ocorreu porque: “(...) a expansão dos estudos sobre a mulher vinculou-se a uma redefinição do político, frente ao deslocamento do campo do poder das instituições públicas e do Estado para a esfera do privado e do cotidiano."

\subsubsection{Uma historiografia brasileira da mulher}

À historiografia brasileira, desde a independência de Portugal, em 1922, e sua forma como Império do Brasil, cumpre um papel fundamental no estudo, questionamento e circunstâncias em que foram escritos os documentos que se voltaram para um tema amplo como a História do Brasil. Em 1830, surgem os primeiros movimentos responsáveis pelo apanhado de documentos produzidos até aquele momento. A independência, nesse caso, pontua o processo de busca e construção de uma história e identidade nacionais e, consequentemente, a forma de inscrição da sociedade brasileira e sua diversidade cultural, o que inclui pensar em todos os resgates que compõem a complexidade de um povo.

Diante desse panorama, está também um olhar para os esquecidos da história, os invisibilizados. O feminino e suas constantes lutas ganham força na década de 70, como já fora dito, e se destaca fundamentalmente pelo trabalho da mulher nas fábricas e por seu papel nas reinvindicações feministas. E é nesse tocante que se pensa a importância do olhar 
da historiografia em direção à mulher e em sua constante participação na sociedade, na família e em movimentos sociais e políticos, o que abre espaço para novas jornadas de discussão e incorporações de categorias importantes como a de gênero (nos textos literários), que passa a ser integrada nos estudos historiográficos e que essa pesquisa pretende rever, a partir da análise de textos da literatura infantil e juvenil, mais adiante.

Nesse contexto histórico posto, a historiografia da mulher data dos anos 80 e aponta para diferentes pontos de vista e aspectos variados no que tange à temática do trabalho nas fábricas, as lutas e as greves femininas. Além disso, segundo Matos, buscou-se resgatar:

As múltiplas estratégias e resistências criadas e recriadas pelas mulheres no cotidiano, bem como sua capacidade de explorar as inconsistências ou incoerências dos sistemas sociais e políticos para encontrar brechas, através das quais pudessem se expressar ou, ao menos, sobreviver. (MATOS, 2000, p. 13)

Grande parte dos trabalhos se voltou para o período colonial e início do século XX, localizando a mulher em espaços públicos e privados, assim observando-se, principalmente, a presença constante em espaços públicos onde suas lutas femininas ganham importância. Do mesmo modo, a mulher foi localizada no espaço urbano em atividades árduas que a colocavam como responsável pelas despesas da casa, isso quando não tinha de prover sozinha o próprio sustento e o da família. Nessa jornada, que passa a ser entendida como uma "cultura de resistência" ${ }^{24}$, destacam-se os estudos sobre o papel do feminino na família, as relações ligadas ao casamento, à maternidade e à sexualidade, questões, dentre outras, centradas nos estudos do período colonial e início do século XIX, desvendando como fontes principais as que estavam ligadas à Igreja e ao Estado.

No que diz respeito ao final do século XIX e começo do século XX, os estudos historiográficos vão destacar outras lutas femininas e suas estratégias cotidianas, como afirma Matos (2000, p. 14): “(...) a educação feminina, a disciplinarização, os padrões de comportamento, os códigos de sexualidade e a prostituição, e priorizaram como fontes as judiciárias e as médicas."

\footnotetext{
${ }^{24}$ Termo utilizado por Matos (2000), a partir dos estudos de E. P. Thompson.
} 
Além disso, a produção historiográfica mostra, ainda, que não se trata, simplesmente, de se colocar a mulher num lugar; no interior de narrativas prontas, isso porque atuaram tanto quanto os homens, ou pelo fato de terem se destacado pelas diferenças de uma "cultura feminina", mas considerando uma grande questão: a de não se poder perder a multiplicidade do ser feminino e cair na mera discussão existencialista da mulher. Afinal, como assinala Matos:

Existem muitos gêneros, "muitos femininos" e "masculinos", e esforços vêm sendo feitos no sentido de se reconhecer a diferença dentro da diferença, apontando que mulher e homem não constituem simples aglomerados; elementos como cultura, classe, etnia, geração, religião, e ocupação devem ser ponderados e intercruzados numa tentativa de desvendamento mais frutífera, através de pesquisas específicas que evitem tendências a generalizações e premissas preestabelecidas. Sobrevém a preocupação em desfazer noções abstratas de "mulher" e "homem", enquanto identidades únicas, a-históricas e essencialistas, para pensar a mulher e o homem como diversidade no bojo da historicidade de suas relações. (MATOS, 2000, 15).

\subsubsection{Diferenças, igualdade}

Em meio às transformações e tensões de um movimento feminista já posto, caminhava a reivindicação de um território específico para si e, consequentemente, de um olhar que o validasse. Sobretudo, considerando-se a insuficiência de material teórico capaz de explicar a persistência da desigualdade entre mulheres e homens. A categoria gênero é considerada, pelos estudiosos, como mais "neutra e objetiva", o que parece dar mais legitimidade acadêmica àqueles que se dedicam a estudar o tema. Para tanto, de acordo com Matos, considera-se que:

Por sua característica basicamente relacional, a categoria gênero procura destacar que a construção dos perfis de comportamento feminino e masculino define-se um em função do outro, uma vez que se constituíram social, cultural e historicamente em um tempo, espaço e cultura determinados. Não se deve esquecer, ainda, que as relações de gênero são um elemento constitutivo das relações sociais baseadas nas diferenças hierárquicas que distinguem os sexos, e são, portanto, uma forma primária de relações significantes de poder. (MATOS, 2000, p. 16-17). 
Matos (2000, p.17) ressalta, também, que os estudos sobre gênero, tendo como preocupação evitar as oposições binárias fixas e naturalizadas, consideram mostrar que: “(...) as referências culturais são sexualmente produzidas, por símbolos, jogos de significação, cruzamentos de conceitos e relações de poder, conceitos normativos, relações de parentesco, econômicas e políticas."

Na década de 90, houve uma ampliação desses estudos o que trouxe à tona outras perspectivas de abordagens, incorporando ainda que tardiamente a questão da violência numa perspectiva histórica, posto a história ser apontada com uma área, no campo interdisciplinar, que mais tem feito investimentos de pesquisa no campo do gênero, colocando-o como central.

Além disso, se, por um lado, os movimentos e outras formas de manifestação passam a ocupar lugar importante, mostrando que a própria história da mulher não se organiza numa linearidade progressiva, mas num "ir e vir", assim também, deve-se considerar que suas lutas e resistências não podem ser vistas separadas de todo um processo de dominação enredada na história.

A diversidade e a multiplicidade de interpretações, a partir das novas abordagens historiográficas, abre um campo vasto de análises e expressões que vão desembocar na condição social da mulher. E, portanto, de acordo com Matos (2000) o social é historicamente constituído e acena para o fato de as experiências sociais feminina e masculina diferenciadas terem suas condições próprias em sociedades específicas.

3.3 Não era uma vez: uma variante de conflitos

Diante das considerações organizadas até aqui, tomamos mais uma narrativa que atualiza a clássica história da menina e do lobo, encontrada na coletânea intitulada Não era uma vez: contos clássicos recontados (2010), ilustrada por Mariana Massarani (figura 64). Em Antecedentes de uma famosa história, conto da autora colombiana Carolina Alonso (figura 65), presencia-se uma obra que projeta um determinado público jovem, bem marcado no discurso, assim como o seu espaço de ação, a escola. 
A obra anuncia já na apresentação do próprio título: Antecedente de uma famosa história, a ideia de que será trazida à tona a realidade de algo acontecido (instaurando certa curiosidade já no título da obra), possivelmente um crime se se considera a ambiguidade do termo, nesse contexto, em que "antecedente" no sentido jurídico está relacionado a criminal e, portanto, registros que guardam todas as possíveis passagens ou acusações que um indivíduo pode ter junto à esfera policial e jurídica. Nessa floresta metafórica depara-se também com questões sobre o comportamento e a educação sexista de meninos e meninas e seus reflexos na sociedade contemporânea.

No século XXI, independentemente de suas classes sociais, meninos e meninas ao iniciarem suas vidas escolares têm em comum o saber partilhado sobre suas identidades sexuais e qual o papel que cada um ocupa nesse espaço, mesmo que não tenham clareza ou conhecimento da amplitude do significado desse conceito.

À escola cabe a tarefa da educação sobre o significado de ser menina, assim como ensinar a clara definição do que é ser menino. Contudo, esse processo não acontece de forma aberta e explícita, mas por meio de estratégias dissimuladas que, em tese, levam a crer que tudo está dentro de uma normalidade previsível e que sequer necessita ser explicada ou justificada, mas seguida como modelo social prescrito para ambos.

Nesse contexto, para além da educação intelectual, a escola deve atuar na formação social dos indivíduos e consequentemente no "moldar" tais meninos e meninas diante dos modelos culturais existentes. Entretanto, o que se observa é que a função da escola deveria ir muito além, uma vez que ela se constrói como espaço de ação, e isso quer dizer que em lugar de ensinar apenas o já pensado e o dito no passado, pode ensinar a pensar o novo, a educar os sentidos para o mundo vivido, a fim de que tanto menina quanto menino reelaborem seus próprios pensamentos. Uma vez que:

Co-educar não é pôr em uma mesma classe indivíduos de ambos os sexos, nem tampouco é unificar, eliminando as diferenças mediante a apresentação de um único modelo. Não é uniformizar as mentes de meninas e meninos; ao contrário, é ensinar a respeitar o diferente e a desfrutar da riqueza que a variedade oferece. (MORENO, 1999, p. 77)

Assim, em lugar de ensinar a obedecer, a escola pode ensinar a questionar, a buscar novas formas de interpretação do mundo, de percepção de si e do outro nesse grande espaço de transformações e não seus modelos, tantas vezes, sexistas que marginalizam a 
mulher, desde o primeiro momento em que ensinam a ser menina e reforçam o lugar de uma concepção centrada na figura do homem - como ser humano, como masculino e centro dos acontecimentos.

No novo modo de ensinar, abrir o leque de possibilidade de expressão de sentimentos é fundamental para o processo de crescimento social. Sobretudo, mostrando que poder expressar sensibilidade e ternura não faz parte de um patrimônio exclusivamente feminino. Mostrar tanto ao menino quanto à menina a liberdade de sentimentos sem que tenham que se submeter a estereótipos que a sociedade, gratuitamente, impõe ao seu gênero também faz parte desse repensar a educação, sem necessariamente se copiar uma reprodução dos modelos já existentes. Essa nova forma de enriquecimento, decerto contribui, como afirma Moreno (1999, p. 75): “(...) e se aprenderá com isso, que há muitas formas de ser mulher, assim como há muitas formas de ser homem."

Os livros, decerto cumprem uma função importante na vida das crianças e dos jovens de todos os tempos. Eles mostram o mundo e dão forma às ideias e pensamentos que moldam a vida desses sujeitos e refletem seus comportamentos. Daí a necessidade de se rever o passado para modificá-lo naquilo que não corresponde à realidade do presente. Tal qual o fizera a historiografia que, no passado, limitava-se a ignorar a mulher, mas fora obrigada a refazer o percurso do olhar motivada pela força do presente. E, com isso, constatar que cumpria um duplo fazer merecedor de críticas e mudanças: o de omitir as histórias sobre o papel da mulher nas sociedades e o de transmitir algo que não condizia com a realidade acontecida, fabricando, muitas vezes, ideologias de dominação.

Em se tratando dos livros com imagens, como se sabe, enquanto linguagem também constroem uma forte significação. Assim, quando se viu, por exemplo, a Chapeuzinho Amarelo, na primeira página de apresentação da narrativa (figuras 38 e 39), deitada e encolhida na cama, com medo de tudo, logo poderia pensar tratar-se de uma figura feminina numa atitude estereotipada de que a mulher é frágil e, portanto, o medo é uma característica comum a ela.

Ou, talvez, deva-se voltar à versão de Dona Baratinha (figura 6), da Ana Maria Machado, em que na primeira capa da obra, centralizada na página - simbolizando a sua importância valorada pela cultura, está a personagem ilustrada - vestida de noiva - , reforçando um lugar da mulher na sociedade, ou seja, o de esposa, dona de casa, mãe. 
No entanto, esse contrato não se efetiva, como se viu. E, então, a personagem resolve viver sua vida e "gastar o dinheiro para se divertir" (ruptura com os papéis sociais investidos na figura da mulher). Escolha tal que a qualifica ou mesmo desqualifica, de acordo com o olhar de determinadas sociedades modernas ainda em transformação, e que continuam apontando esse tipo sujeito como personagem fútil, supérfluo. Assim:

Vemos como os livros de linguagem não ensinam só a ler, assim como não é o domínio do idioma a única coisa que cultivam, mas sim todo um código de símbolos sociais que comportam uma ideologia sexista, nãoexplícita, mas incrivelmente mais eficaz do que se fosse expressa em forma de decálogo. Meninas e meninos tendem de maneira irresistível a seguir os modelos propostos, principalmente quando lhes são oferecidos como inquestionáveis e tão evidentes que nem sequer necessitam ser formulados. (MORENO, 1999, p. 43).

E o que dizer do fato da personagem Dona Baratinha ser representada por aquilo que por muito tempo simbolizou "medo" ou "nojo" para o sujeito feminino, a barata?

\subsubsection{Era uma vez, outra vez}

Figura 54 - Não era uma vez: primeira capa Figura 55 - Antecedentes de uma famosa história

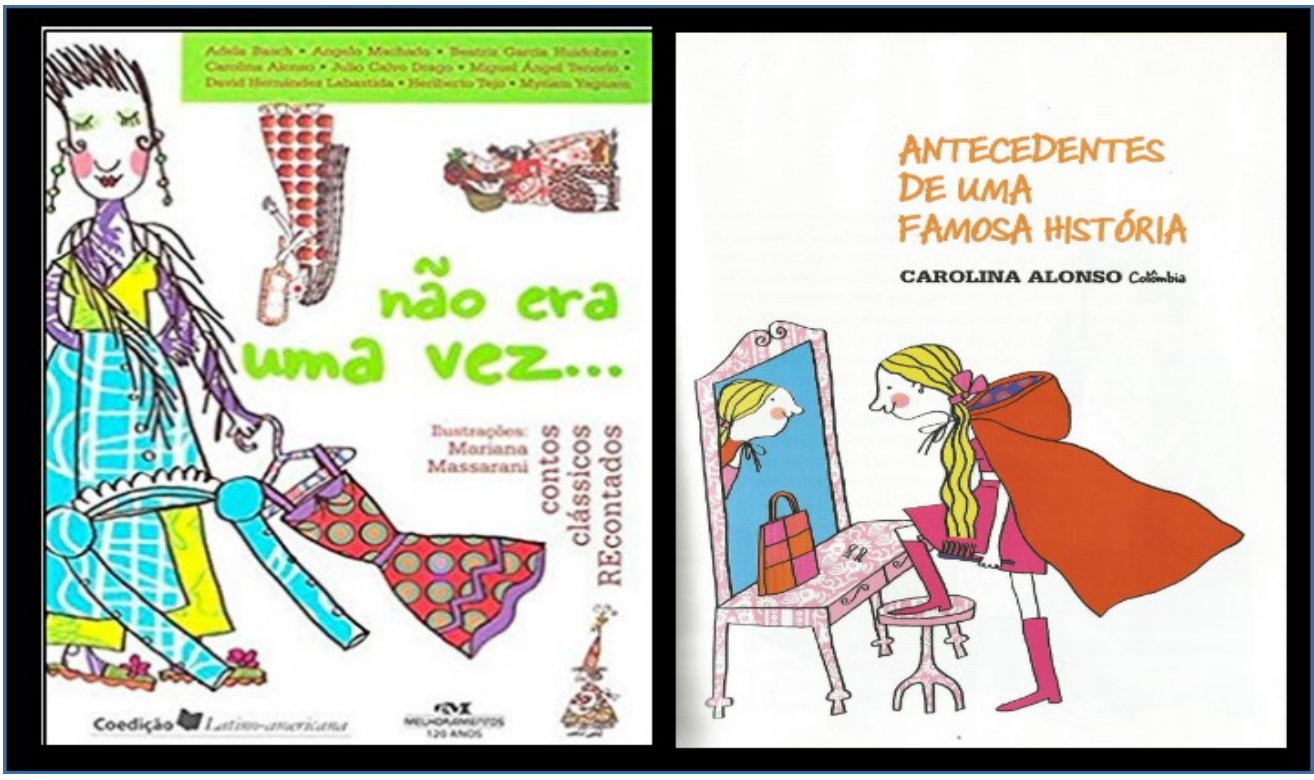

Fonte: Editora Melhoramentos (2010) 
Logo na primeira página da narrativa de Antecedente de uma famosa história (2010), de Carolina Alonso, que faz parte de uma coletânea de contos de autores latinoamericanos (figura 55), ilustrados por Mariana Massarani, o leitor se depara com a figura de um jovem em conflito, ocupando espaços como sujeito do viver as grandes paixões, e seus valores mutáveis. Os valores como amor, paixão, ódio, inveja, ciúme, traição, medo, etc., presentes nas narrativas primordiais de todos os tempos são mais uma vez questionados na história de Alonso. Nesse caso, pelo viés passional que coloca em cena os sujeitos masculino e feminino em ato. Sobre valores, Candido afirma que:

Como as pessoas, os valores, que são ideias, nascem, padecem sorte vária e morrem. Sua raiz é modesta e comum. As necessidades elementares da vida individual, projetando-se na vida coletiva, se sublimam em normas. Essas, desfeita a placenta que as nutre, se apresentam, como valores autônomos, eternos, universais. Em torno deles se constroem as ideologias, proliferam outros valores, forma-se o tecido das ilusões caras à existência. As instituições vicejam à sua sombra e a conduta se organiza segundo a sua diretriz. (1996, p. 270).

A atualização, nesse contexto, se dá pelo que parece ser outra a forma de se mostrar as personagens e seus conflitos. Contudo, ao contrário das narrativas vistas nas histórias de Chapeuzinho Amarelo e Chapeuzinho Vermelho, em que se tinha um narrador em terceira pessoa, agora o foco narrativo muda, instalando um narrador-personagem (que se utiliza do recurso flasback para contar sua própria história - recuperar a memória) confuso, muito angustiado e desnorteado, em sua primeira aparição (figura 56):

Tudo começou há três semanas, três terríveis semanas. Fiquei trancado dias e noites em meu quarto sem dormir, revirando na cama até que o calor intenso me fazia levantar. Caminhava pelo quarto e logo sentia calafrios horríveis que me arrepiavam a pele e me obrigavam a me retorcer, a me encolher como um recém-nascido largado em um campo gelado. Sob as cobertas, cavoucava como um animal. Sem parar de tremer, adormecia e me voltava a febre, um calor insuportável que transformava as lembranças em imagens imprecisas, fragmentadas de pesadelos. Ouvia vozes em minha cabeça que não se calavam nunca. Depois surgiam sussurros que vinham de todo lado, olhares de olhos selvagens que me atormentavam sem me deixar em paz. (ALONSO, 2010, p. 56). 
Figura 56 - Conto: página de abertura

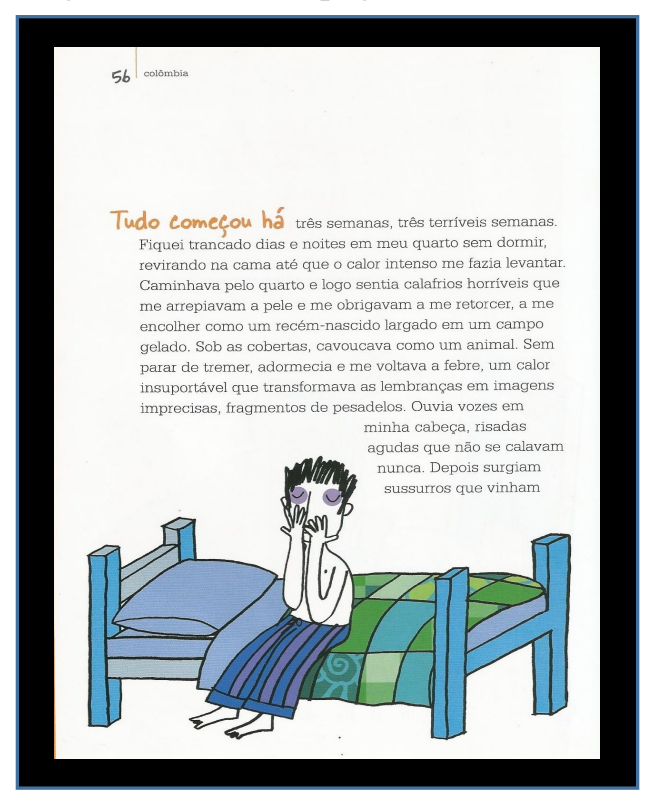

Fonte: Editora Melhoramentos (2010)

Nota-se que o conflito vivido pelo sujeito jovem, nesse primeiro momento, será justificado nas páginas seguintes, situação em que ele rememora os acontecimentos que o fizeram passar por uma metamorfose. Isso inclui uma decepção amorosa muito grande, com rigores de detalhes, podendo ser vista como uma espécie de morte simbólica da inocência dos afetos diante da humilhação na presença de seus pares.

Tal qual nas narrativas clássicas em que a menina encontra com o lobo na floresta ou bosque, todo o desenrolar da trama, aqui, se dará no espaço bosque, lugar onde o menino vai ao encontro tão esperado com aquela que imaginava ser uma pessoa única e a mais especial - a garota de seus sonhos (ALONSO, 2010, p. 58): "Imaginava que ela era diferente, porque às vezes, quando nos cruzávamos no pátio, olhava-me com expressão doce; possivelmente de pena, não sei. Enganou-me.” (figura 57). 
Figura 57 - "Nosso encontro"

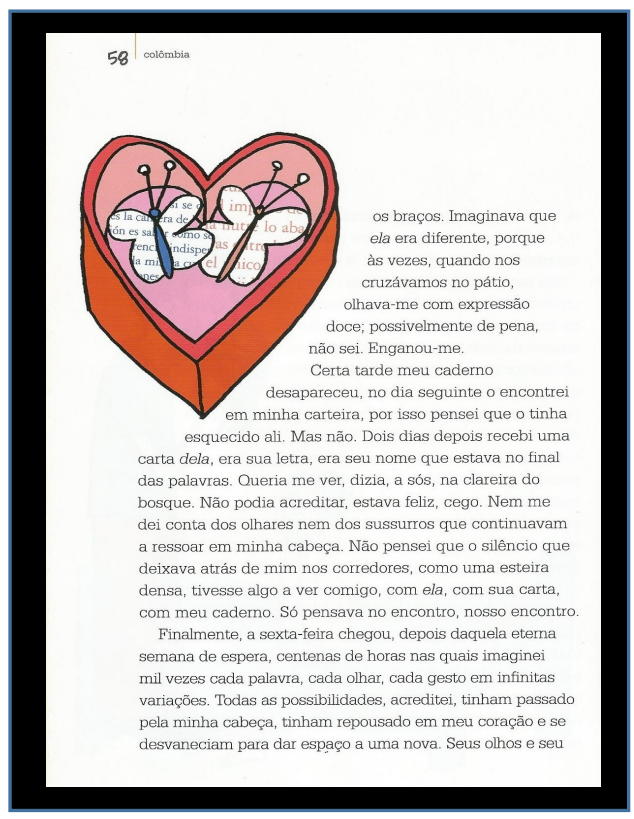

Fonte: Editora Melhoramentos (2010)

No desenrolar da narrativa, percebe-se como o menino (que não é nomeado, bem como nenhuma das personagens da história, o que poderia significar certa falta de autonomia) tem seu sonho de amor, literalmente, quebrado, suas memórias amorosas (escritas em um caderno) expostas a todos os colegas do colégio que zombavam dele pelos corredores. E pior que isso, sofre uma emboscada inesperada, pois a garota que era, segundo ele (ALONSO, 2010, p. 57): “(...) a razão para levantar de manhã, para suportar os dias", agora estava revestida com os valores do Lobo Mau.

E foi, justamente, no encontro marcado no bosque (por meio do jogo de sedução) que ela se revelou insensível e má. Enquanto ele a esperava sentado num tronco, a menina chegando por trás coloca as mãos nos olhos do menino, que ouve um (ALONSO, 2010, p. 59): “Olá”. Então, sente o perfume já conhecido, encantado pelo pedido da voz que gostaria de saber sobre os seus sentimentos não percebe, como todo apaixonado, que está sendo levado para uma situação vexatória e dessacralizante (figura 58). 
Figura 58 - "Olá!

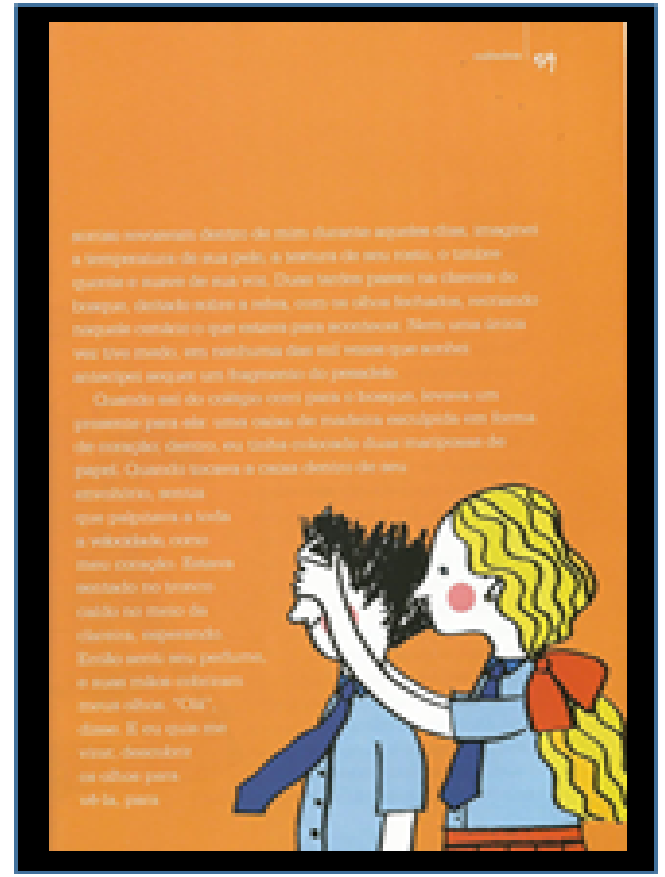

Fonte: Editora Melhoramentos (2010)

Assim, depois de ser humilhado no centro de uma roda de amigos da menina que riam e giravam em seu redor e ouvir (ALONSO, 2010, p. 61): "Eu não te amo, seu idiota", além de ter presenciado a destruição do presente (um coração com duas mariposas dentro) que ele havia feito para ela, o garoto em meio a tantas sensações ruins que sentia, viu seu coração, literalmente, ser despedaçado (ALONSO, 2010, p. 61): “ 'Ei, mariposinha, gritou o que estava abraçado com ela. 'Olhe'. E jogou com toda sua força meu coração contra uma árvore; ele se partiu em pedaços.” (figura 59). 
Figura 59 - "Eu não te amo, idiota"

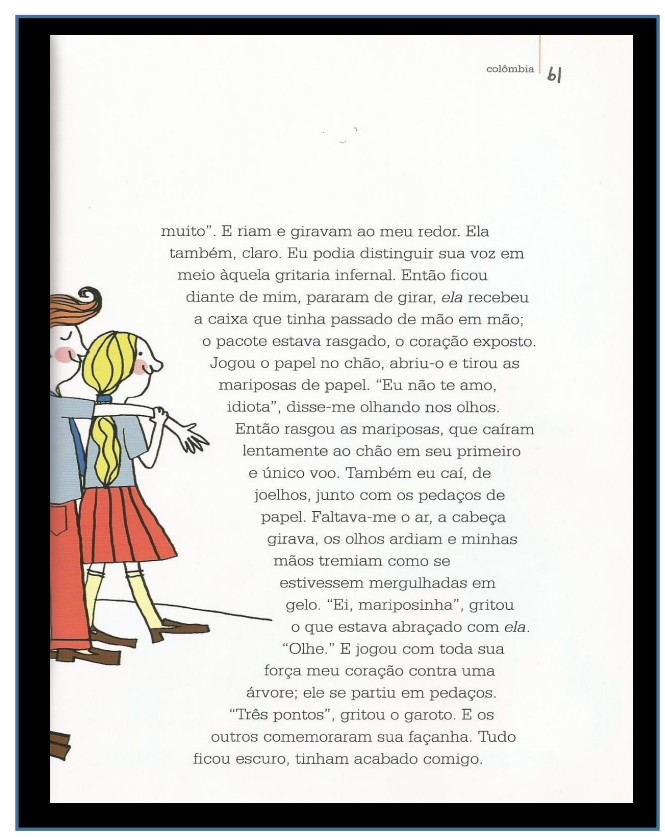

Fonte: Editora Melhoramentos (2010)

As últimas duas páginas (figuras 70 e 71) do conto, mostram, sobretudo pela visualidade, a transformação ou metamorfose do sujeito menino em lobo. Nessa relação, igualmente vemos ser anunciada uma outra mudança: a da menina transfigurada em Chapeuzinho Vermelho, dada a ver pela capa com capuz vermelho e uma bolsa que lembra uma cesta, caminhando pelo bosque, com indisfarçada "inocência", até a casa da avó e sem desconfiar da visita inesperada que terá pelo caminho.

Nesse pressuposto pelo dito no texto verbal e confirmado pela linguagem visual, há o anúncio de que a história não terá um fim como no conto dos irmãos Grimm ou mesmo tal qual a narrativa poética de Buarque, ao contrário, a alusão recai diretamente na versão de Perrault, cuja organização do contexto já anuncia o desfecho: o lobo faminto engolindo a menina e a avó. Veja-se a seguir:

Desde então fiquei trancado com as cortinas fechadas, sem poder suportar a luz. Três semanas sem comer nada, embora sentisse o corpo vazio, como uma marionete abandonada depois de uma apresentação. As vozes não paravam de me atormentar, misturadas em minha cabeça com imagens grotescas. Ferem-me, todos querem me ferir. Ontem à noite saí quase me arrastando, voltei ao bosque para recuperar os pedaços do meu coração 
arrebentado. Encontrei também os pedaços de papel. Cavei um buraco, ao lado do tronco caído no meio da clareira, e enterrei tudo ali.

Chorei pela última vez; já não tinha mais lágrimas, não tinha nada. Em algum momento dormi profundamente, como se também eu tivesse caído naquele buraco.

Ao amanhecer, havia uma força dentro de mim, algo desconhecido e poderoso que me dominava. Uma criatura que cresce, furiosa e faminta. Já não sou eu, não posso fazer nada. Não posso lutar contra isso; não quero. Não posso me levantar, distingo com nitidez o aroma de tudo o que me cerca, as coisas perderam sua cor. Nada me dói, não sinto frio, uma couraça de pelo duro e negro me protege. Tenho fome, muita fome...

Ouço uma voz, alguém que se aproxima. Esse canto é uma das vozes do coro maligno, quero que se cale. Vejo-a: uma capa vermelha que atravessa o bosque em direção à casa da avó que mora no final do caminho. Não resisto e vou em direção a ela. (ALONSO, 2010, p. 62-63).

Figura 60 - "Chorei pela última vez"

Figura 61 - Uma capa vermelha

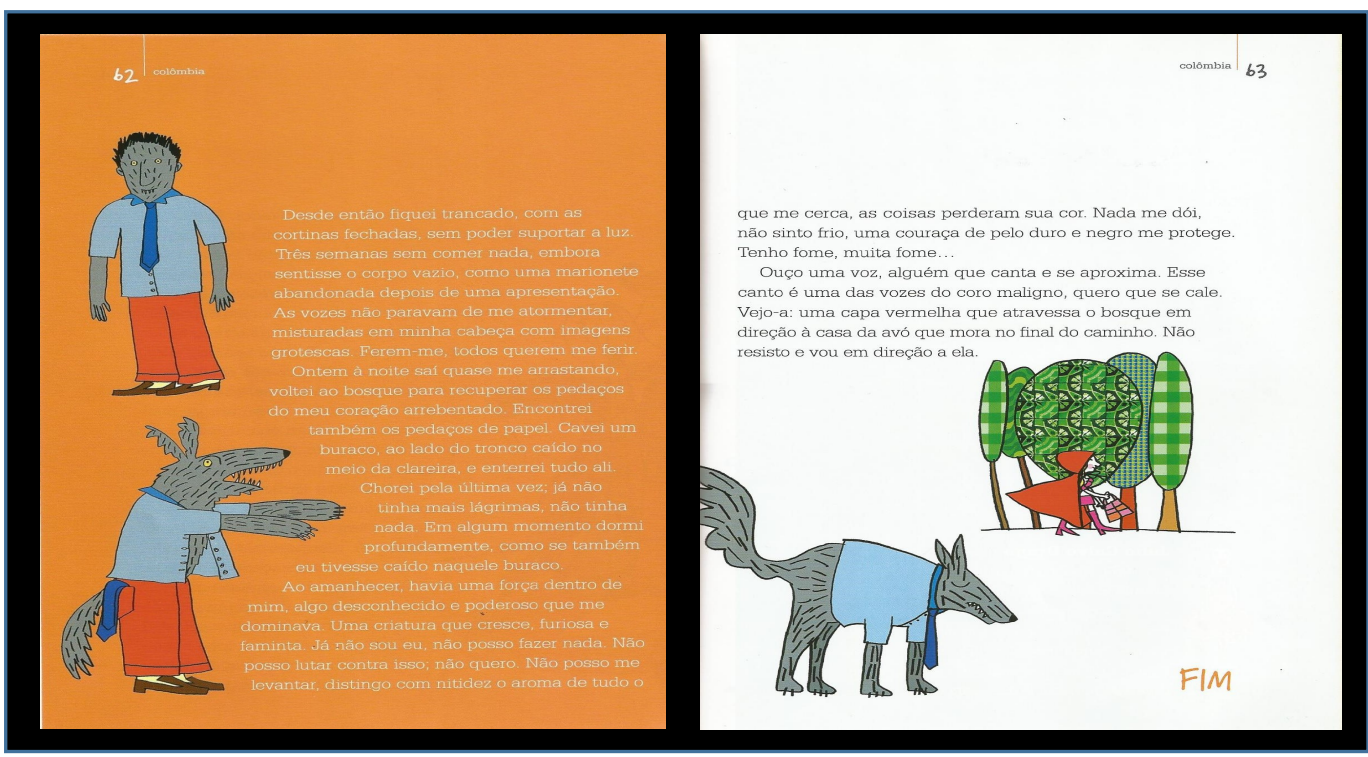

Fonte: Editora Melhoramentos (2010)

Diante do contexto, que atualiza narrativas populares, é interessante observar, ainda, a construção de outra personagem presente no imaginário popular e inúmeras vezes inscrita em textos de suportes diferentes: o lobisomem. Afinal, a representação na figura híbrida de homem e lobo não é desconhecida, pois desde tempos imemoriais este ser, metade homem e metade lobo, provoca desassossego no inconsciente coletivo que ainda hoje guarda na memória do imaginário a figura de um animal cruel. Sobre o qual, Zilberman, diz: 
O lobisomem, ou licantropo, é figura frequente nas várias culturas ocidentais, sua gênese, enquanto entidade mítica, remonta à antiguidade. Enraizou-se na cultura popular brasileira, representando a possibilidade de metamorfose de um ser humano em animal, cuja bestialidade traduz as forças incontroláveis do instinto e da violência. (ZILBERMAN, 2014, p.186).

Nesse tocante, não é possível ignorar a presença do fantástico, numa passagem da narrativa (figuras 60 e 61), a partir da relação do duplo inscrita no discurso do menino transformado em "coisa".

Ao amanhecer, havia uma força dentro de mim, algo desconhecido e poderoso que me dominava. Uma criatura que cresce, furiosa e faminta. Já não sou eu, não posso fazer nada. Não posso lutar contra isso; não quero. Não posso me levantar, distingo com nitidez o aroma de tudo o que me cerca, as coisas perderam sua cor. Nada me dói, não sinto frio, uma couraça de pelo duro e negro me protege. Tenho fome, muita fome... (ALONSO, 2010, p. 62-63).

Esta dualidade, de certo modo, remete ao fenômeno especular: espelhos e reflexos permeando as lendas, as histórias de magia, as tradições populares e carregando sentimento de insegurança individual, social ou coletiva. É uma temática recorrente nos temas literários de raízes mitológicas e folclóricas em que o duplo representa não só o lado escuro; o lado sinistro, mas o mundo onde a diferença é dada por meio do sentido e do valor. Ou, por assim dizer, de acordo com Eco (1989, p. 20): “o fato de a imagem especular ser, entre os casos de duplicatas, o mais singular, e exibir características de unicidade, sem dúvida explica por que os espelhos têm inspirado tanta literatura".

Do mesmo modo, Arthur Arnold (1986) sublinha que neste relato o lobo é percebido como uma força do mal e, incisivamente, como um instrumento de punição que castiga as meninas que desobedecem à autoridade familiar, e isso, faz de certo modo, alusão ao grau de violência a que a mulher ainda continua sendo submetida, sobretudo quando se trata de se pensar a atualização de valores sociais, politização de espaços públicos e privados ocupados por elas e por suas lutas e culturas de resistência.

Ao mesmo tempo, ainda, remete à discriminação da mulher, que aliás começa muito cedo, talvez antes do nascimento, e fica bem marcada socialmente quando ela chega à escola. E mesmo que frequente espaços mistos é nas brincadeiras livres que vão se exercitar os modelos de conduta aprendidos, pois esse é o momento em que afloram as 
fantasias com as quais cada indivíduo vai se identificar, no momento de "liberdade vigiada," com a limitação dada pelas normas estabelecidas, pois acreditando que estão livres, meninos e meninas identificam-se com os arquétipos destinados a eles, não para transgredi-los, mas para repetir o que aprenderam. Assim:

As meninas têm liberdade para ser cozinheiras, cabeleireiras fadas madrinhas, mães que limpam seus filhos, enfermeiras, etc., e os meninos são livres para ser índios, ladrões de gado, bandidos, policiais, "superhomens", tigres ferozes ou qualquer elemento da fauna agressiva. (MORENO, p. 32).

Tal relação de valores ainda pode ser manifestada, por exemplo, na "charge midiática" (figura 62), a seguir, que circula nas redes sociais. E nela se pode notar, pelas marcas intertextuais, novamente, o resgate de uma dada narrativa matriz da história da Chapeuzinho Vermelho, todavia atualizada em tempo, espaço, suportes e linguagens diversas, levando-se em conta, nesse novo arranjo, outros leitores, capazes de perceber o efeito de sentido de perigo ou alerta que a floresta midiática ou virtual metaforizada representa. Isto é, lugar em que a criança, representando a inocência, é ilustrada como presa fácil para os Lobos que nela circulam com suas intencionalidades maléficas de origem.

Como se observa, essa concepção negativa do lobo continua presente como referência na contemporaneidade, assim também como a da fragilidade feminina. Essas figuras, portanto, continuam sendo revestidas por valores que atualizam não só os tipos de sujeitos, mas os espaços onde circulam. Nesse sentido, a figurativização, ou seja, a instalação de figuras no nível da iconização, visa a revestir exaustivamente as figuras, produzindo a ilusão referencial que as transforma em imagens do mundo. Tais revestimentos narrativos, podem ser recuperados como elementos que reforçam valores culturais e sociais em sociedades distintas temporalmente ou em constantes diálogos e retomadas. 
Figuras 62 - Encontro na floresta virtual

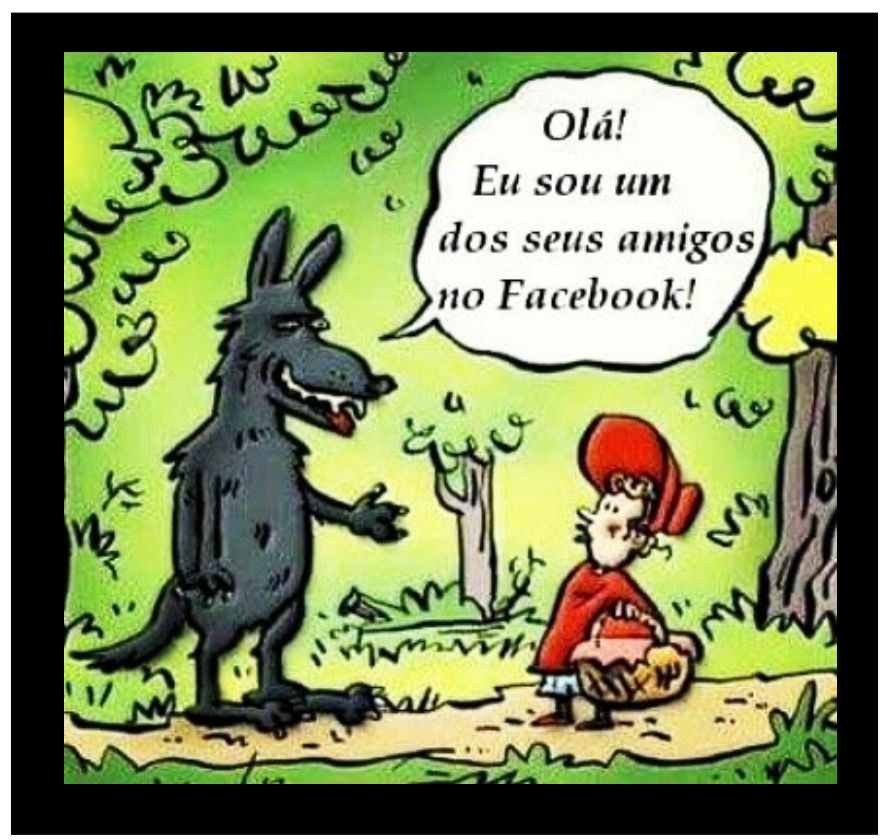

Fonte: Charge retirada da Web $(2014)^{25}$

\subsection{Fratura no tempo e no espaço: estereótipos em reconstrução}

Numa atualização intitulada A outra história de Chapeuzinho Vermelho (2016), de Jean-Claude R. Alphen (figura 73), que também é responsável pela ilustração do livro, tem-se a história recontada sob o ponto de vista do lobo que não é mau, e é apresentado com valores subvertidos, em relação aos lobos das versões de Perrault, dos Grimm, de Buarque e de Alonso, mostradas aqui.

Nessa narrativa, tal qual acontece com a desconstrução da figura do ogro em Shrek (apresentada no capítulo II), o lobo (investido com valores positivos) é totalmente desinvestido de maldade, traço que sustentou a sua figura como horrenda e assustadora no imaginário de adultos e crianças, por séculos. Aqui, o lobo que parece ter aparência de mau (bem alto, grande, pelos escuros, dentes afiados) contrasta com sua essência manifesta e

\footnotetext{
${ }^{25}$ Ver em Obvious - cultura colaborativa - http://obviousmag.org/
} 
denuncia um sujeito que, além de adorar guloseimas, é carente por amigos e convívio social.

Já na primeira capa do livro (figura 63), depara-se com a figura do Lobo e da Chapeuzinho Vermelho frente a frente como num primeiro contato ou encontro (que a narrativa vai confirmar), vistos num fundo todo branco que os destaca visualmente, sobretudo pelos tons de preto do lobo, de estatura alta e, pela cor vermelha, da roupa da menina de estatura baixa. Esse contraste visual anuncia duas figuras já bem conhecidas, mesmo por aquelas crianças que, na contemporaneidade, ainda nem aprenderam a ler o verbal, mas certamente já sabem ler bem as imagens.

Figura 63 - A outra história de Chapeuzinho Vermelho: primeira capa

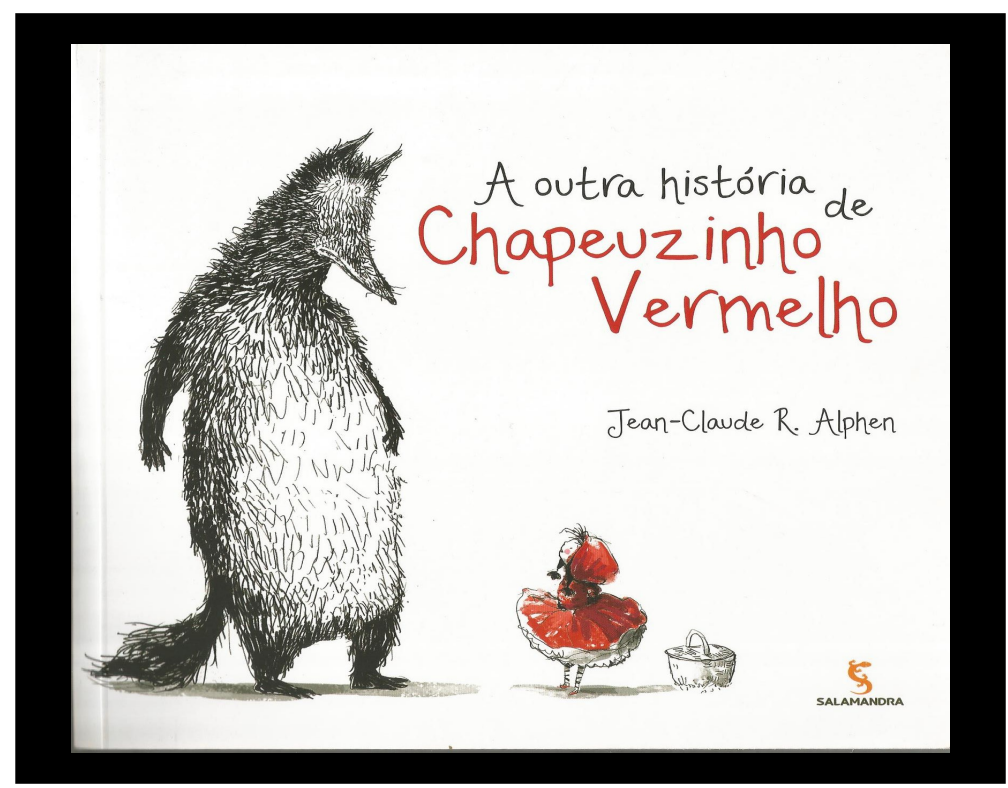

Alphen (2016)

É interessante observar alguns elementos nessa história, sobretudo por suas especificidades, tais como a figura de uma menininha mostrada como um ser impaciente com a rotina da vida que leva (um tipo de estereótipo da criança contemporânea), cujas falas já nas primeiras páginas (figuras 64, 65 e 66) revelam um certo tédio, posto não acontecer nada de diferente na floresta onde todos os dias caminha para visitar a avó e levar algumas guloseimas: "Que dia mais chato!" (figura 66). 
Essa projeção, em contrapartida, reflete o próprio tédio do leitor, inscrito nessa história tantas vezes contada sob a perspectiva da maldade e do medo que atravessaram o imaginário de gerações.

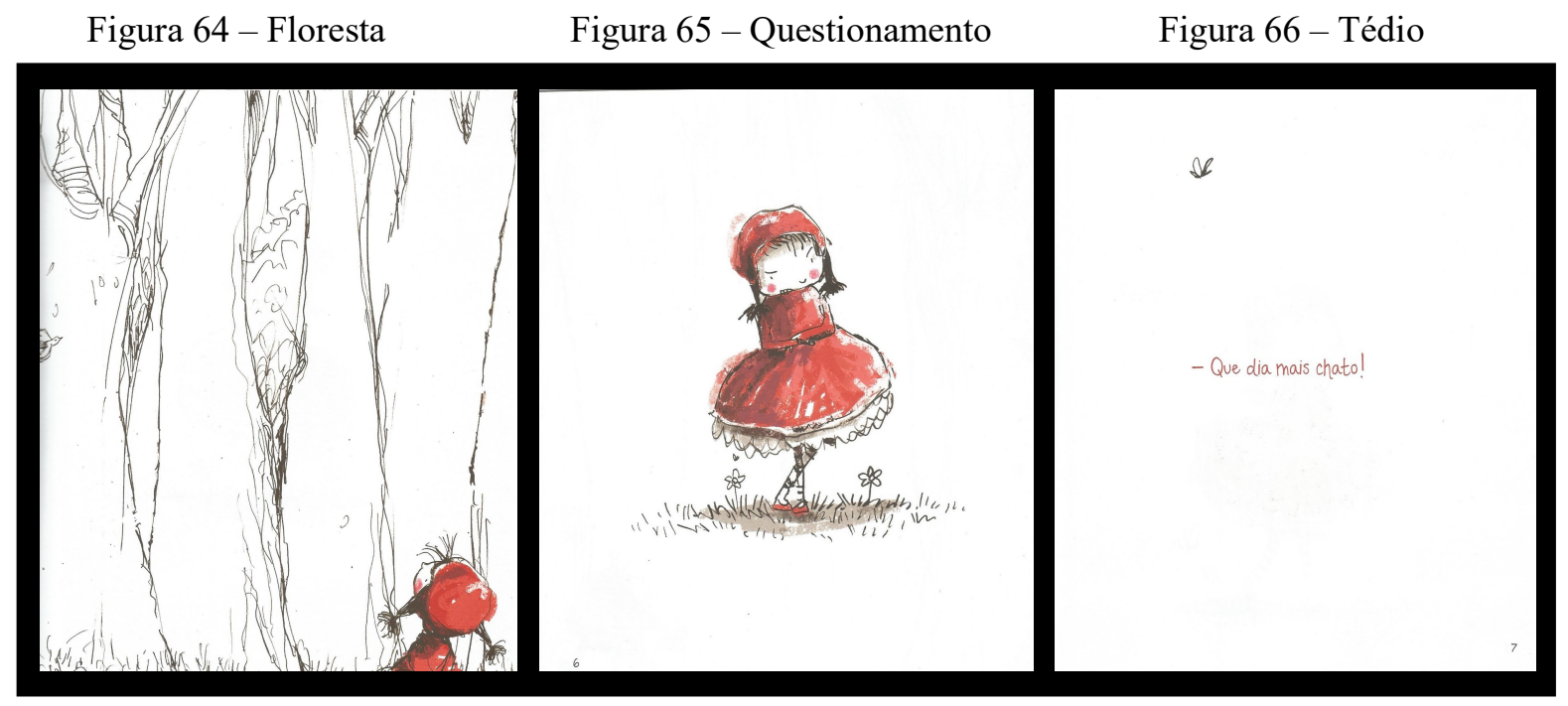

Fonte: Alphen (2016)

Além disso, a menina, ao contrário das outras Chapeuzinhos, não se mostra tão passiva diante da ordem da mãe, sendo capaz de se rebelar e dar a ela resposta bem direta, o que configuraria, ainda, falta de respeito, pois retrucar como resposta a um pedido da mãe, dizendo: “ - De novo? ”, fosse qual fosse o pedido não estava na maneira de como as coisas deveriam ser no passado e, muito menos, no presente, segundo os "bons livros para crianças".

Por outro lado, isso reflete que a criança construída nesse texto é capaz de questionar; se inquietar, uma vez que ela vive e percebe as mudanças em seu entorno (caracterizada como um indivíduo com certa autonomia). A preocupação materna com a presença do desconhecido se faz presente nesse contexto, por meio de uma linguagem bem despojada e articulada com o uso de variantes da língua (linguagem coloquial), ponto predominante em toda a narrativa: "E não dê trela para estranhos...", organizando, desde o início do enredo, um tom de leveza e intimidade com o leitor.

A floresta sendo o cenário do desenrolar da trama é mostrada, pelas imagens em tons de cinza e preto, um ar meio assustador, onde Chapeuzinho Vermelho quase 
sucumbida pela ilustração da floresta, que ocupa duas páginas, (figuras 67 e 68), é visualizada apenas por uma de suas faces, no canto esquerdo inferior da página (figura 67), cujo olhar amedrontado vai alcançar a copa das árvores. Tal manifestação propõe, pela percepção aguçada com que a menina é construída como sujeito, um estado de mudanças tanto dela própria quanto da floresta.

Há, ainda, inscrito nesse contexto, um diálogo com o leitor visto pelo uso tanto da interjeição que acusa espanto; surpresa quanto pelo uso da função fática, quando a menina testa o canal com o seu interlocutor, colocando-o no ato da cena e dividindo com ele seus conflitos: “- Eita! Que escuro!/Dá medo, né?”.

É importante considerar que as imagens são projetadas como no cenário de um texto fílmico (como estratégia de captação), levando o olhar do leitor a passear por todos os cantos da página como se fosse uma tela, criando efeitos de obscuridade e tensão, a partir dos vários planos e ângulos que o texto visual, corroborado pelo verbal, apresenta, não só no início da narrativa, cuja tensão só vai se desfazer com a aparição do lobo, mas também nos estados de euforia divididos entre as personagens da história (a menina, o lobo e a avó).

Figura 67 - No escuro da floresta

Figura 68 - Medo

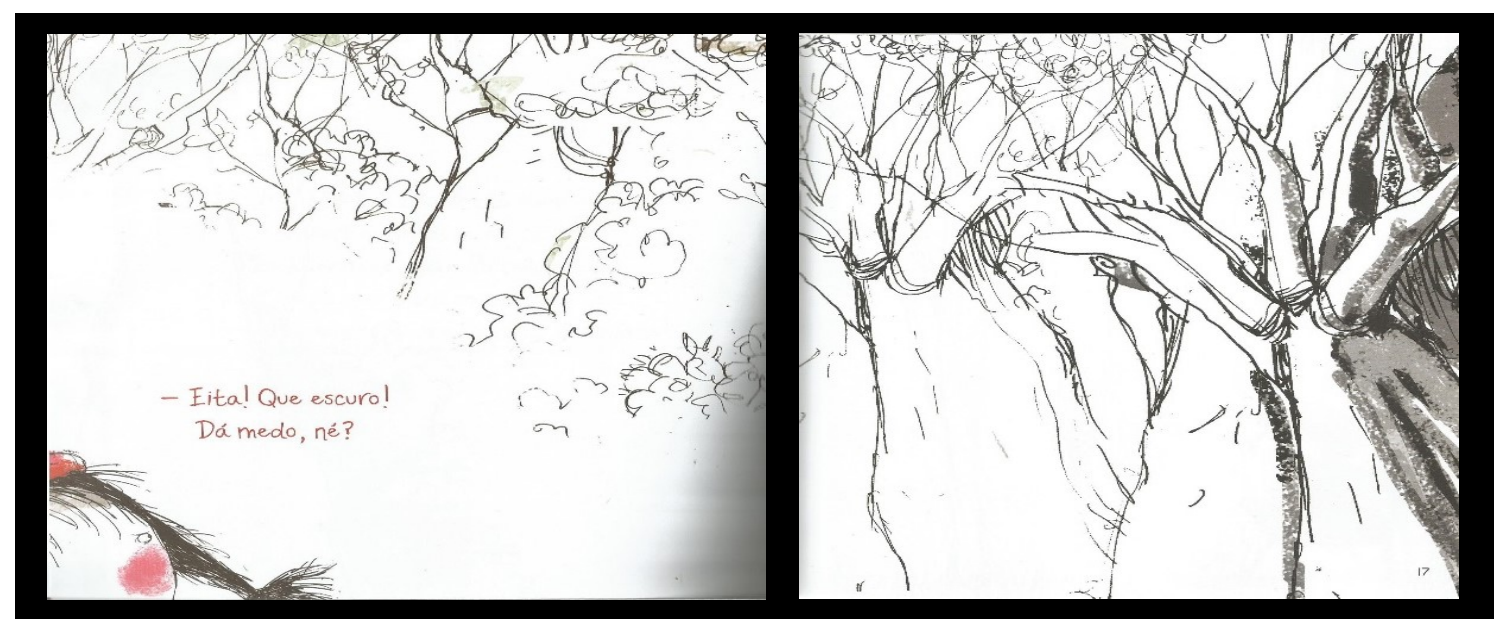

Fonte: Alphen (2016)

Na sequência, surge o momento em que a menina depara com o lobo na floresta e, partir de então, estabelece um diálogo com ele que, cordialmente, a cumprimenta com uma linguagem bem própria da fala ou oralidade, ação que cria um efeito de intimidade ou aproximação: “- Olá!” (figura 69). Esse movimento segue acompanhado de largo sorriso e 
aceno de braço, rompendo com todo o drama construído na cena que antecede a conversa. Em reposta, a menina diz: “ - Ufa! Por um momento, eu achei que fosse um estranho./Que susto que você me deu! ”. E, com o uso de variante linguística; gíria, o lobo responde: “Desculpe./Foi mal...”. (figuras 69, 70 e 71), corroborando o estado de intimidade que se estabelece, a partir desse primeiro contato, entre ambos.

Figuras $69-\mathrm{O}$ encontro

Figura 70 - Um estranho

Figura 71 - Lobo bom

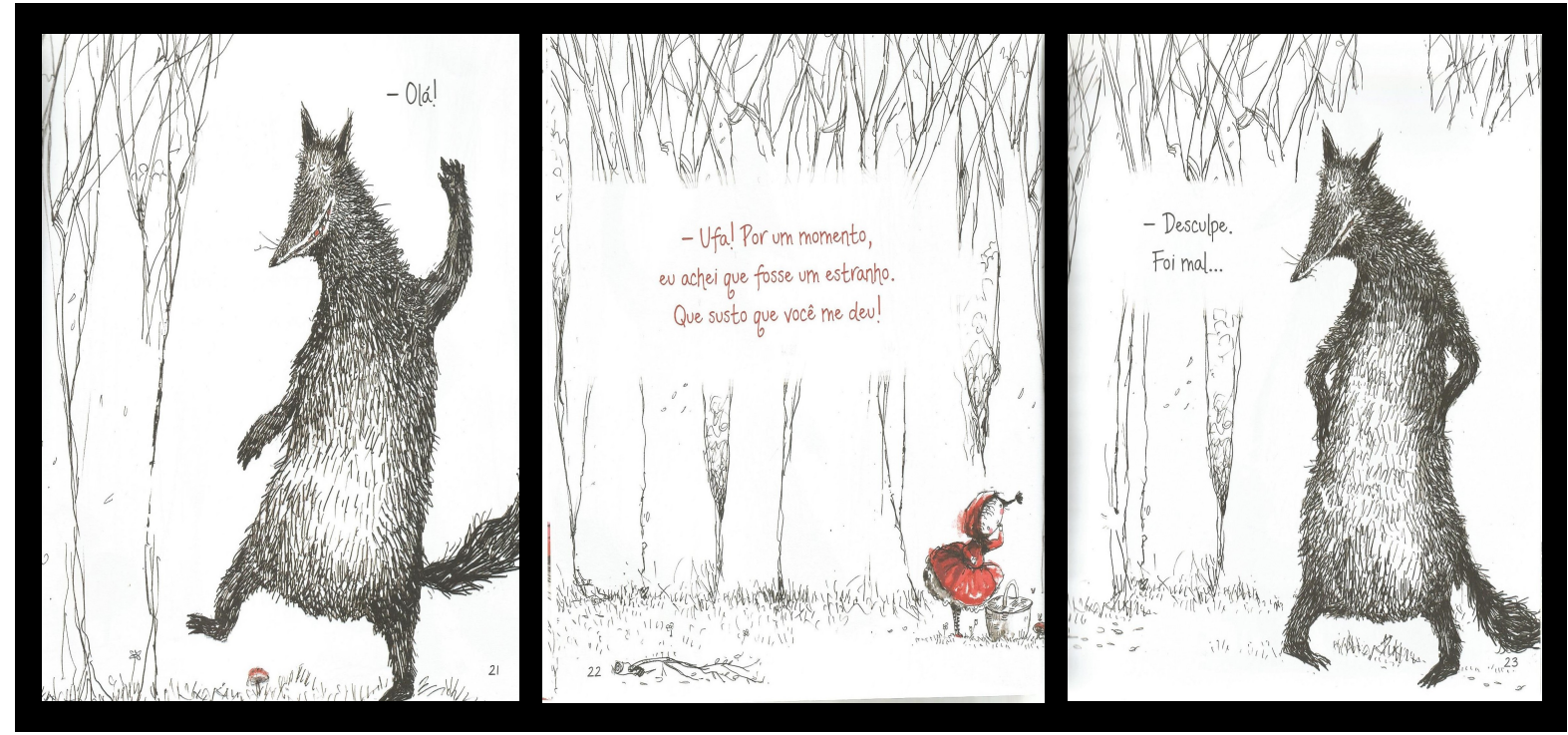

Fonte: Alphen (2016)

É a partir desse primeiro contato que outra narrativa começa a ser esboçada. $\mathrm{O}$ lobo e a menina vão adentrar numa longa conversa (suscitada pela presença inusitada de um livro na cesta que a Chapeuzinho levava para a avó) cujo teor vai retomar tanto a versão da história de Perrault (sobretudo pelo clássico diálogo entre a Chapeuzinho Vermelho e o Lobo Mau, quando o mesmo se passa pela avó que ele já havia engolido) quanto a dos irmãos Grimm quando estes inserem o lenhador como o herói que vai salvar a vida da menina, a de sua avó e colocar fím à vida do lobo (figuras 72, 73, 74, 75, 76, 77 e 78). 
Figura 72 - Era uma vez

Figura 73 - A mesma história

Figura 74 - Outra vez

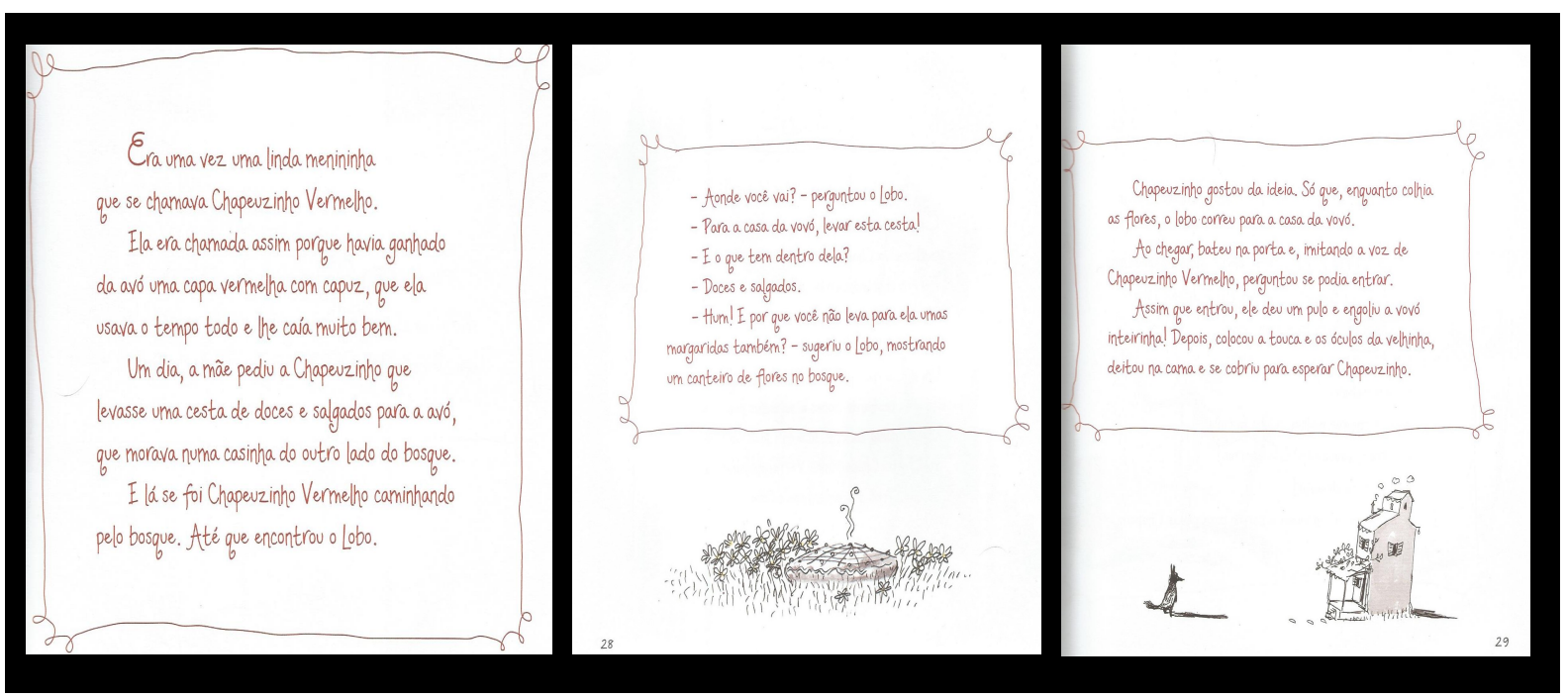

Fonte: Alphen (2016)

Figura 75 - Mais perto

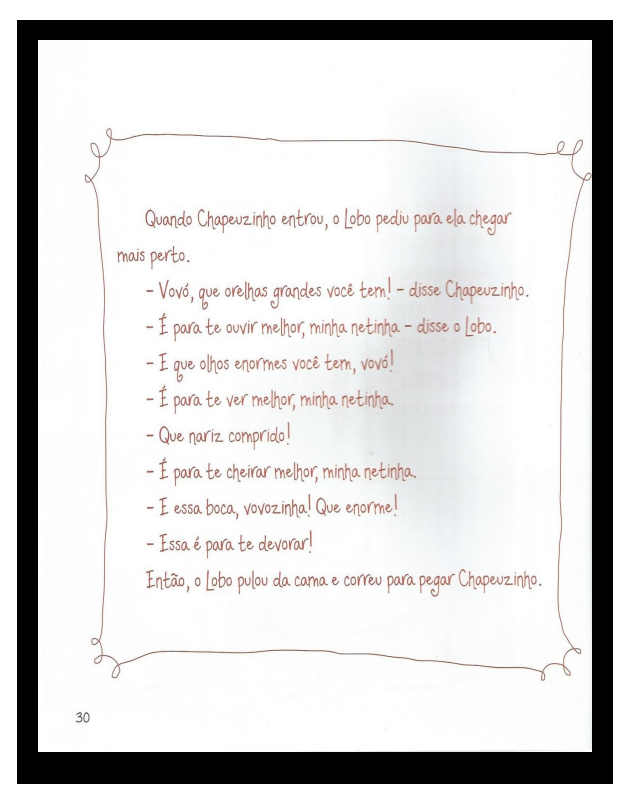

Fonte: Alphen (2016) 
Figura 76 - Era uma vez

Figura 77 - Não era uma vez

Figura $78-$ Fim

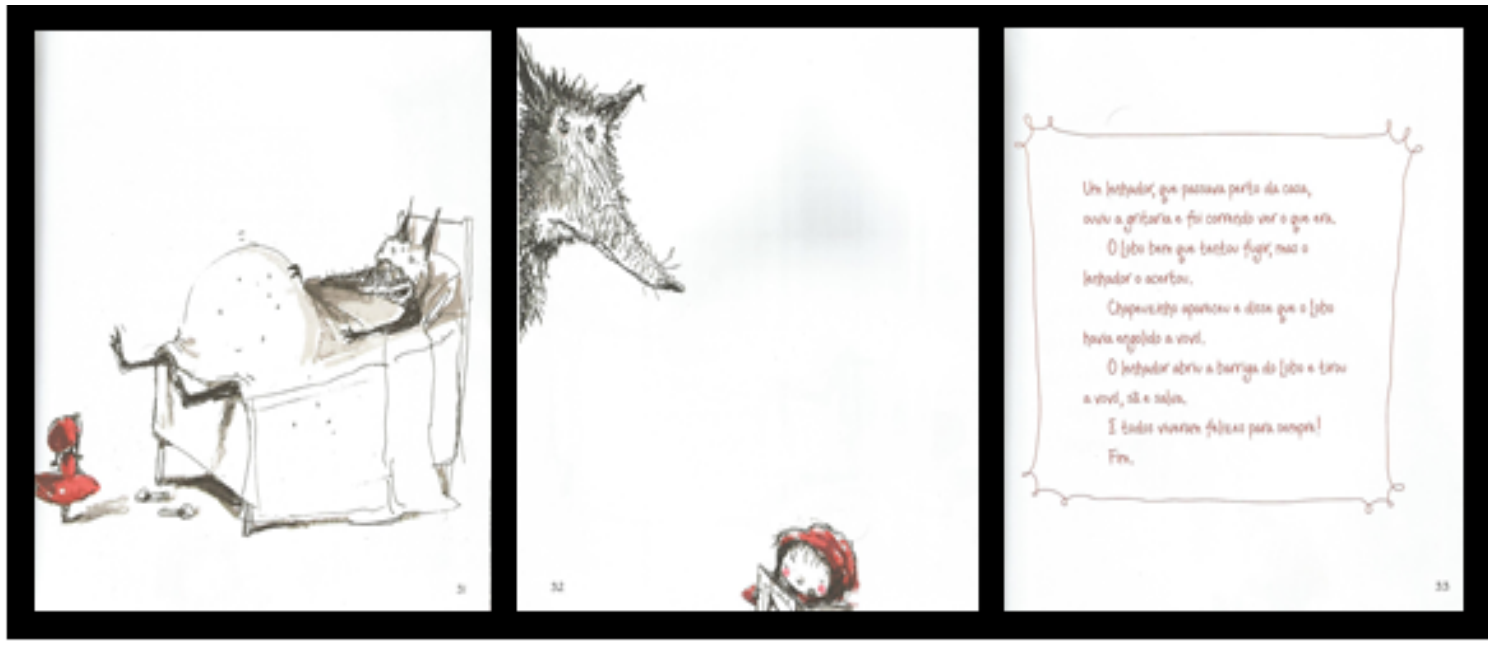

Fonte: Alphen (2016)

Ao final daquela narrativa, contada por Chapeuzinho, o Lobo é questionado sobre a história, e para espanto do leitor o que se vê é um lobo extremamente chateado e ofendido, além de totalmente descontente com o final feliz apresentado naquela história da Chapeuzinho Vermelho em que o lobo morre no final (alusão direta à versão dos Grimm). E em tom questionador e sem disfarce, responde (figuras 79 e 80): “- Eu, não!/Não mesmo!/Nessa história, pelo que eu entendi, nem todo mundo viveu feliz para sempre!"

Figuras 79 - "Gostou?"

Figura 80 - Um novo final feliz

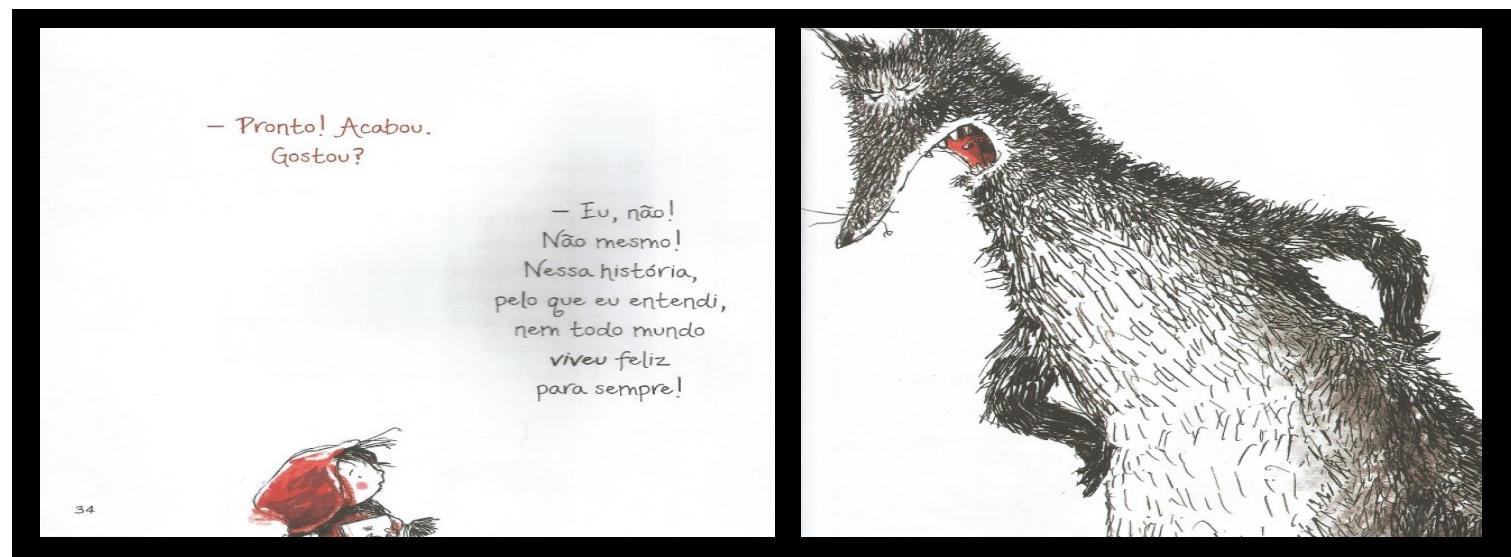

Fonte: Alphen (2016) 
E é assim que ele finda por propor outro final, uma nova atualização para a narrativa na qual, segundo o lobo (antropomorfizado com as qualidades da bondade), seria convidado pela vovó para jantar e ele próprio faria "deliciosas panquecas de cogumelos, além de deliciosas panquecas de morango com calda de chocolate". Aqui é o momento em que o lobo carente e sensível se manifesta, sintetizando o que de fato está em jogo, ou reafirmando um valor familiar em discussão na contemporaneidade: o estar junto: “- E seria um verdadeiro encontro de amigos".

$\mathrm{Na}$ sequência, quando questionado pela Chapeuzinho se a história dele se resumia a isso, não tarda em corroborar esse valor, contando o resto, o que inclui o lobo ser convidado pela vovó para dormir no sofá-cama da sala e ainda para saborear um bom café da manhã no dia seguinte. Mais do que contente em falar da sua versão, ele, em tom de euforia e certa ironia velada (figuras 81 e 82), arremata dizendo à menina: “- Bem melhor do que essa história de lobo mau!/Você não acha?" Nesse cenário, como se vê os conflitos são desfeitos e o presente (menininha) e o passado (avó) do feminino, revisitados, também sofrem alteração.

Observa-se que a atualização da história da Chapeuzinho Vermelho acontece dentro do próprio texto, a partir do recurso de se explicar uma história dentro da outra, ou seja, a partir do uso do metatexto ou do metadiscurso, como forma de ressignificar a memória, ao mesmo tempo em que apresenta as transformações, por meio das correções dos valores ou desvalores do passado.

Figura 81 - A versão do lobo

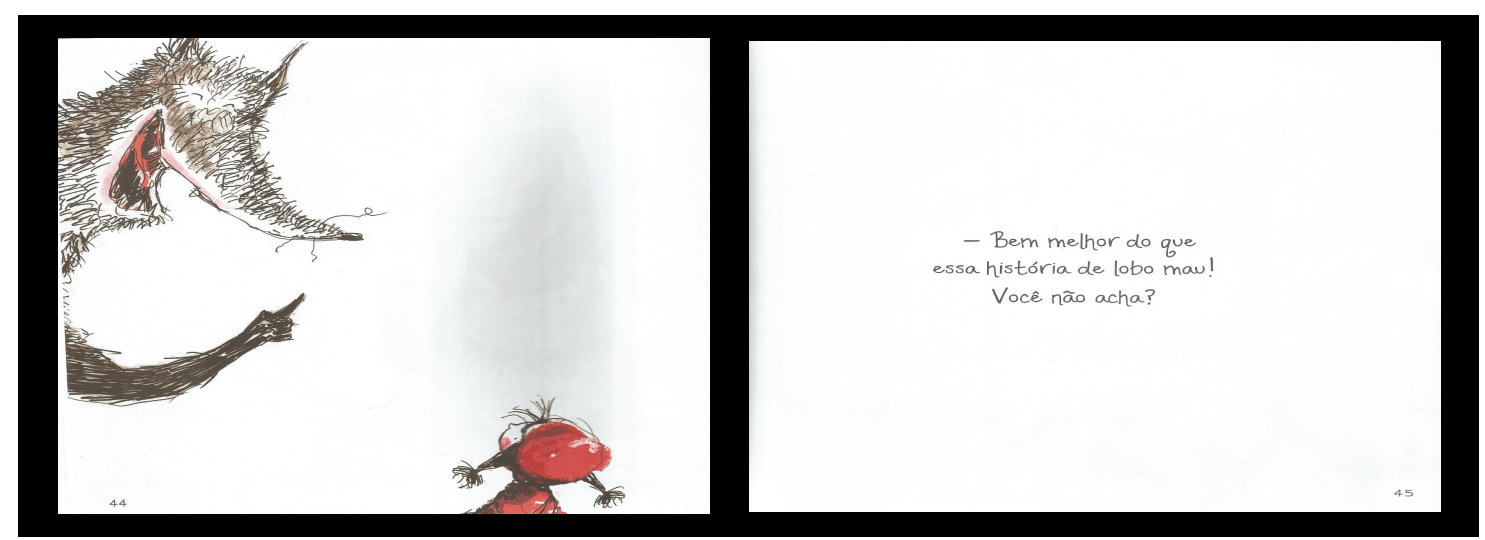

Fonte: Alphen (2016) 
$\mathrm{Na}$ sequência dos acontecimentos, o Lobo Bom acompanha a Chapeuzinho Vermelho até a casa de sua avó e é convidado pela velhinha para uma xícara de chá. Mas, como ele, que além de ser muito comilão e dotado de muita gentileza e boa educação, não perde a oportunidade de se colocar às ordens e, assim, se oferecer para preparar as panquecas, motivo que gera alegria para as três personagens que, agora, de fato têm um final feliz, de acordo com o modo de ver da nova narrativa do sujeito lobo (figuras 83 e 84).

Figura 83 - Um final feliz para todos

Figura 84 - Lobo e panquecas

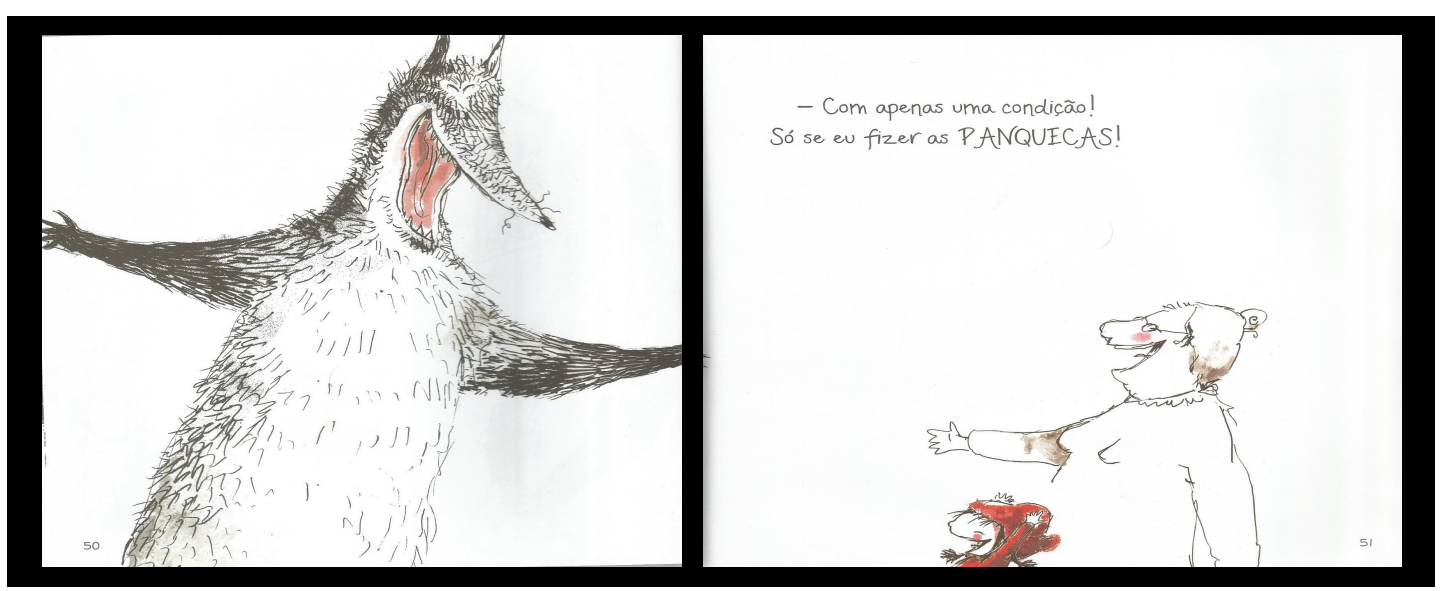

Fonte: Alphen (2016)

Finalmente, a quarta capa (figura 85), com fundo todo em vermelho, traz a presença do lobo (na posição de "olá", vista anteriormente), atravessado também pelo vermelho que se mistura com a pelagem preta de seu corpo, criando um efeito híbrido em que ele pode ser visto tal qual a protagonista Chapeuzinho Vermelho, uma vez que assume os valores do bem. 
Figura 85 - A outra história de Chapeuzinho Vermelho: quarta capa

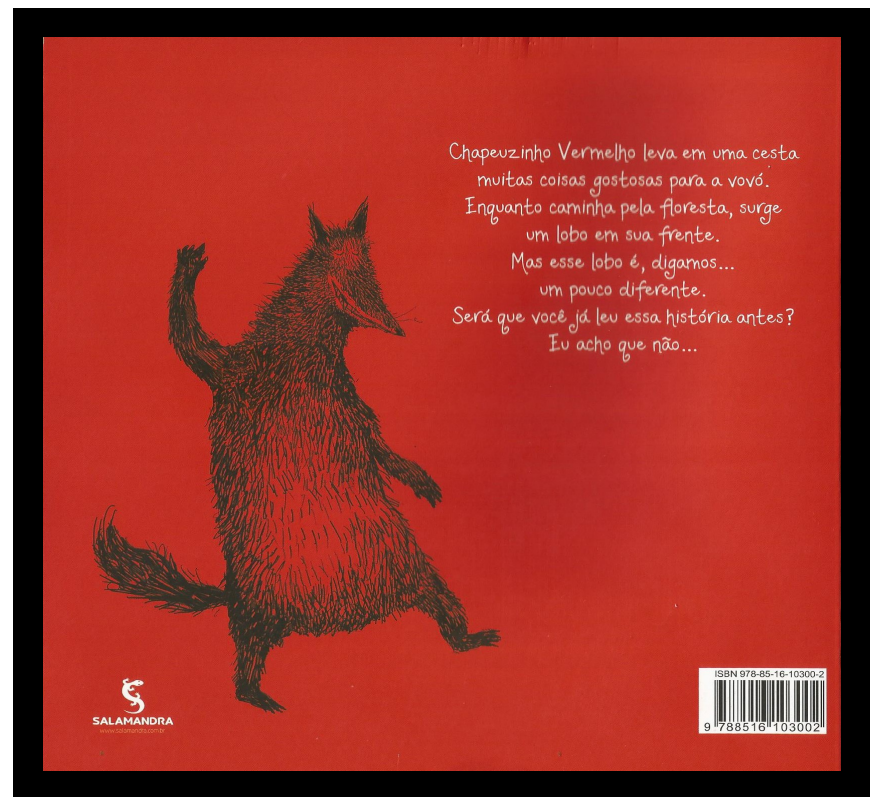

Fonte: Alphen (2016)

\subsection{Literatura infantil e juvenil: valores e desvalores}

Nesse espaço, a pesquisa intenciona continuar mostrando, a partir da retomada do clássico brasileiro Chapeuzinho Amarelo, de Chico Buarque, ilustrado por Ziraldo, considerando a relação comparatista com o clássico Chapeuzinho Vermelho, de Charles Perrault (com a ilustração de Doré) e a versão dos Grimm, além das duas obras já apresentadas (Antecedentes de uma famosa história, de Alonso e A outra história da Chapeuzinho Vermelho, de Alphen), outros diálogos possíveis que essas obras podem estabelecer entre si ou com outras obras da literatura, cuja presença constante da criança e do jovem, revela-se em novas maneiras de apresentar o texto, denunciando um dado processo de atualização e desdobramentos capazes de revigorar, significativamente, as narrativas primordiais.

Serão considerados os textos produzidos a partir da década de 70, levando-se em conta o caráter de multilinguagem organizado nas obras desse período e o reflexo da qualidade estética e plástica dos textos, capazes de denunciar uma também qualidade 
literária que se organizou, a partir da segunda metade do século XIX, projetando em diferentes contextos, valores sociais e culturais em trânsito.

Nesse processo, estarão as seguintes obras nas edições em uso: Chapeuzinho Amarelo (2006), de Chico Buarque, ilustração de Ziraldo, Chapeuzinho Vermelho (1996), de Charles Perrault, Chapeuzinho Vermelho, dos Grimm (2009) - no caso particular tanto da versão de Perrault quanto na dos Grimm, trabalhar-se-á com as traduções, Sapato de salto (2011), de Lygia Bojunga, Antecedentes de uma famosa história (2010), de Carolina Alonso, ilustração de Mariana Massarani, conto publicado em Não era uma vez: contos clássicos recontados - coletânea de autores latino-americanos, A outra história de Chapeuzinho Vermelho (2016), de Jean-Claude R. Alphen, ilustrada pelo próprio autor e as intersecções forjadas no texto Preciosidade (1991), de Clarice Lispector, conto publicado em Laços de família.

Duas definições são importantes para as análises que seguem, dadas as transformações dos sujeitos sociais e suas diferentes formas de apreensão do mundo. A primeira diz respeito ao termo cultura e a segunda é relativa ao termo sociedade. As definições que seguem foram retiradas do Dicionário de Filosofia, de Abbagnanno, e apresentadas da seguinte maneira e pela ordem, ou seja, a primeira definição refere-se ao termo cultura e a segunda ao termo sociedade:

[...] essa palavra hoje é especialmente usada por sociólogos e antropólogos para indicar o conjunto dos modos de vida criados, adquiridos e transmitidos de uma geração para a outra, entre os membros de determinada sociedade. Nesse significado, C. não é a formação do indivíduo em sua humanidade, nem sua maturidade espiritual, mas é a formação coletiva e anônima de um grupo social nas instituições que o definem. Nesse sentido, esse termo talvez tenha sido usado pela primeira vez por Spengler, que com ele entendeu "consciência pessoal de uma nação inteira"; consciência que, em sua totalidade, ele entendeu organismo vivo; e, como todos os organismos, nasce, cresce e morre. "Cada C, cada surgimento, cada progresso e cada declínio, cada um de seus graus e de seus períodos internamente necessários, tem duração determinada, sempre igual, sempre recorrente com forma de símbolo" (Untergang des Abendlandes, I, p. 147). Do conceito da C. assim entendida, Spengler distinguia o conceito de civilização, que é o aperfeiçoamento e o fim de uma $\mathrm{C}$, a realização e, portanto, o esgotamento de suas possibilidades constitutivas. "A civilização", diz Spengler, "é o destino inevitável da cultura. Nela se atinge o ápice a partir do qual podem ser resolvidos os problemas últimos e mais difíceis da morfologia histórica. As civilizações são os estados extremos e mais 
refinados aos quais pode chegar uma espécie humana superior. São um fim: são o devindo que sucede ao devir, a morte que sucede à vida, a cristalização que sucede à evolução. (ABBAGNANO, 2007, p. 228).

$\mathrm{Na}$ linguagem comum e nas disciplinas sociológicas a palavra $\mathrm{S}$. costuma ser usada no terceiro significado, de conjunto de indivíduos caracterizado por uma atitude comum ou institucionalizada. Neste sentido, designa tanto um grupo de indivíduos quanto a instituição que caracteriza esse grupo, como acontece nas expressões "S. comercial", "S. capitalista", etc. Esse emprego é tão óbvio que em geral não é sequer definido. Às vezes é definido em relação com cultura, como fazem Kluckhohn e Kelly: "S. refere-se a um grupo de pessoas que aprenderam a agir em conjunto; cultura refere-se aos modos de vida que distinguem esse grupo de pessoas" (R. ÜNTON, 'Ihe Science of Man in the World Crisis. 7J ed., 1952, p. 79). (ABBAGNANO, 2007, p. 914).

Por sua vez, Raymond Williams define cultura e sociedade, concomitantemente, da seguinte maneira:

A palavra só esteve disponível no sentido moderno quando o substantivo independente, nos sentidos artístico, intelectual ou antropológico, tornouse familiar. A hostilidade à palavra cultura em inglês parece datar da controvérsia a respeito da posição de Arnold. Ganhou força no final do S19 e início do S20, em associação com igual hostilidade a esteta e ESTÉTICO (v.). Sua associação com distinções de classe produziu o arremedo culchah*. Havia também uma área de hostilidade associada a sentimento antialemão, durante e após a Primeira Guerra, em relação, à propaganda sobre Kultur. A área central de hostilidade persistiu, e um de seus elementos foi enfatizado pela recente expressão norte-americana culture-vulture [cultura-abutre]. É significativo que praticamente toda a hostilidade (com a única exceção da temporária associação antialemã) tenha sido vinculada aos usos que envolviam afirmações de conhecimento superior (cf. o substantivo INTELECTUAL), refinamento (culchah) e distinções entre arte "alta" (cultura) e arte e entretenimento populares. Ela registra, portanto, uma história social real e uma fase muito difícil e confusa do desenvolvimento social e cultura. É interessante que o uso social e antropológico em constante expansão de cultura e cultural e deformações como subcultura (a cultura de um grupo discernível menor) tenha ou eludido ou diminuído a hostilidade e o mal-estar embaraçoso que lhe são associados, exceto em certas áreas (notadamente no entretenimento popular). O uso recente de culturalismo para indicar um contraste metodológico com estruturalismo na análise social mantém muitas das dificuldades anteriores e nem sempre evita a hostilidade. (WILLIAMS, 2007, p. 123-124).

Por volta do S19, pode se ver sociedade de modo suficientemente claro como um objeto que permite formações, como reformador social (embora social também fosse usado, e ainda se use, para descrever companhia pessoal; cf. vida social e noite social). Ao mesmo tempo, ao ver sociedade como um objeto (a soma objetiva de nossas relações) era possível definir de novas maneiras a relação entre homem e sociedade ou 
entre indivíduo e sociedade como um problema. Essas formações demonstram a distância relativamente ao primeiro sentido de camaradagem ativa. Os problemas que elas indicam no desenvolvimento real da sociedade forma significativamente ilustrados no uso da palavra social, em princípios do S19, para contrastar uma ideia de sociedade como ideia de cooperação mútua e a experiência de sociedade (o sistema social) como competição individual. Essas definições alternativas de sociedade não poderiam ter ocorrido se o sentido mais geral e abstrato não se tivesse firmado por volta dessa época. Foi a partir dessa ênfase de social, em um sentido mais positivo que neutro, e como contraste a INDIVIDUAL (v.), que o termo político SOCIALISTA (v.) se desenvolveria. Um adjetivo alternativo, societal, foi utilizado na etnologia desde inícios do S20 e hoje faz uma referência mais ampla e mais neutra a formações e instituições sociais gerais. (WILLIAMS, 2007, p. 123-124).

Tais definições são importantes na medida em que mostram, por meio de processos de evolução, contextos culturais e sociais capazes de projetarem-se como instituições reguladoras de valores e, portanto, responsáveis pelos contratos que determinam as condições de circulação e as ações dos sujeitos sociais. Assim, com a finalidade de observar como se estabelecem essas transformações, em diferentes temporalidades e seus reflexos em diferentes contextos sociais, são colocadas em foco, além das obras mencionadas, outras em edições mais atuais

Ao ler a obra de Chico Buarque é pouco provável que o leitor não seja, automaticamente, remetido à obra de Charles Perrault, considerando-a como a primeira versão mais famosa a ser publicada. Isso de muitas formas, parece ter sido mostrado até aqui, em capítulos anteriores. No entanto, o que não se considerou, mais especificamente, foi o fato da narrativa de Buarque se construir pela semelhança com aquela matriz do passado para mostrá-la pela diferença de traços sociais e culturais bem marcados e conectados com seu tempo e em franco diálogo com outras obras.

Isso posto, nos textos que seguem, será considerado como momento importante de captação imediata do leitor, diante da história da menina do capuz vermelho e do lobo mau, a remissão a dois momentos icônicos do clássico Chapeuzinho Vermelho, de Perrault: o primeiro (1) se constitui como aquele em que o lobo aborda a menina na floresta e o segundo momento (2), portanto, é quando o lobo já está na casa da avó da criança à espera dela para o desfecho cruel. Ou seja, nesse cenário estão os famosos diálogos que a menina e o lobo estabelecem, os quais antecedem o momento em que Chapeuzinho e sua avó são devoradas. 
Esses dois momentos, observados nos textos selecionados para análise, embora apareçam de modo diferente àqueles do texto matriz, não passam despercebidos ao mais desatento leitor, pois a força dos elementos narrativos, em novos arranjos, convoca imediatamente os sentidos do leitor, despertando-lhe a memória; o imaginário.

Observem-se os trechos da obra de Perrault, a seguir, acompanhados da ilustração feita por Gustave Doré (figura 86), cena ambígua em que a menina e o lobo estão na cama. Ilustração forjada a partir das metáforas (provocações; seduções) constituídas pela própria narrativa verbal de Perrault e corroborada pela moral (usada como epígrafe desse capítulo) instituída em versos, ao final da história.

Figura 86 - Os contos de Perrault: Chapeuzinho Vermelho

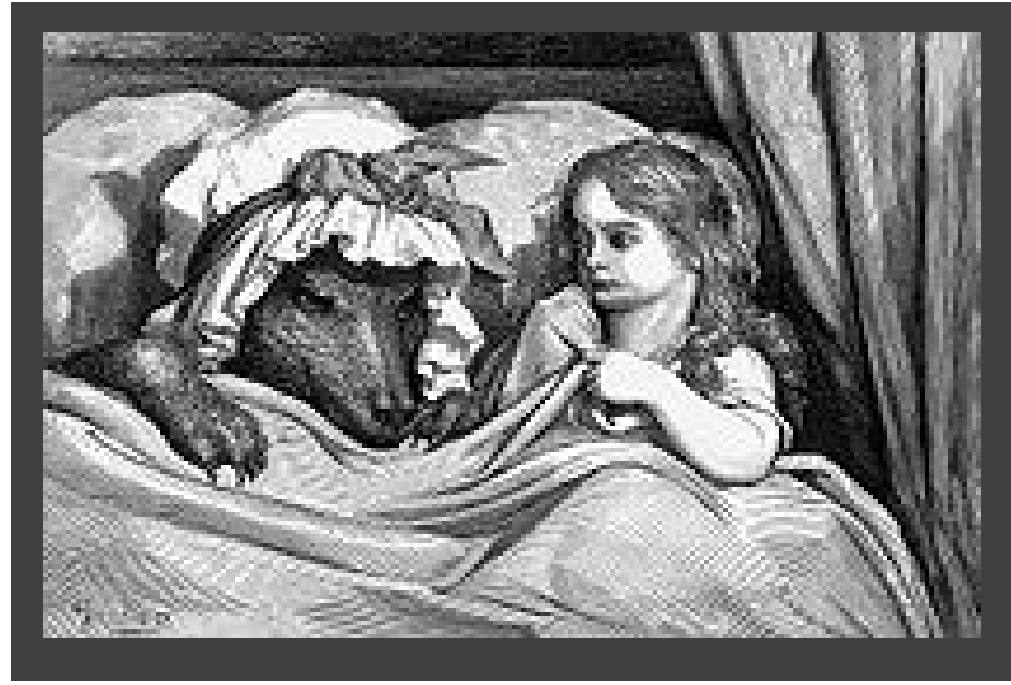

Fonte: Perrault, Doré (1697)

(1)

Chapeuzinho Vermelho partiu para a casa da avó, que morava em outra aldeia.

Passando dentro de um bosque, encontrou o Compadre Lobo, que teve logo vontade de comê-la.

Mas não ousou fazer isso, por causa de uns lenhadores que estavam na floresta.

- Para onde você está indo? - perguntou então. (PERRAULT, ALMEIDA, 1996). 
(2)

Põe o bolo e o potezinho de manteiga sobre a arca e vem deitar-te ao meu lado.

Chapeuzinho Vermelho fez isso.

Ficou muito espantada vendo como sua avó estava diferente. Disse:

- Vovó, que braços grandes a senhora tem!

- É para te abraçar, minha neta.

- Vovó, que pernas grandes a senhora tem!

- É para melhor correr, minha filha.

- Vovó, que orelhas grandes a senhora tem!

- É para escutar, minha criança.

- Vovó, que olhos grandes a senhora tem!

- É para melhor te enxergar, minha querida.

- Vovó, que dentes grandes a senhora tem!

- É para te comer.

E, dizendo essas palavras, o malvado lobo jogou-se sobre Chapeuzinho Vermelho e comeu-a. (PERRAULT, ALMEIDA, 1996).

Esses atos, de certa forma, fazem do encontro entre menina e lobo um dos mais revisitados por diferentes pontos de vista de estudo (incluindo o da psicanálise, de Bettelheim ${ }^{26}$ ) e suportes textuais variados no recontar dessa história de cultura popular. E, em se tratando, diretamente da narrativa de Perrault, seu "não final feliz" foi motivo para as mudanças na narrativa que vai figurar como nova na "história romântica" dos irmãos Grimm, no século XIX.

Nessa versão dos irmãos Grimm ${ }^{27}$, (figura 87), o desfecho que também acontece depois do encontro na floresta, como pode ser visto a seguir, vai ser modificado, portanto, pois os autores desejosos por uma história menos violenta, instituem a presença de um herói na figura do caçador que vai salvar a Chapeuzinho e sua avó. Mas para isso, o caçador tem de se livrar do lobo, cuja barriga ele abre com tesoura para a retirada da menina e da velha senhora e, em seguida, enche com pedras grandes que a menina, também, vai ajudar a colocar.

\footnotetext{
${ }^{26}$ Ver sobre o assunto em BETTELHEIM, B. A Psicanálise dos Contos de Fadas. Rio de Janeiro: Editora Paz e Terra, 1977.

${ }^{27}$ Contos de Grimm, no original alemão Kinder- und Hausmärchen é uma coletânea de contos de fada e outros contos, de Jacob e Wilhelm Grimm (os famosos irmãos Grimm), publicada inicialmente em 1812, na Alemanha, pela Editora Random House. Trata-se do primeiro volume, portanto, organizado com 86 histórias dentre as quais está Capuchinho Vermelho (Rotkäppchen). Além dessa, foram publicadas ao todo sete edições amplamente ilustradas, primeiro por Philipp Grot Johann e após sua morte, em 1892, por Robert Leinweber.
} 
Figura 87 - Contos de Grimm; Capuchinho Vermelho: primeira capa

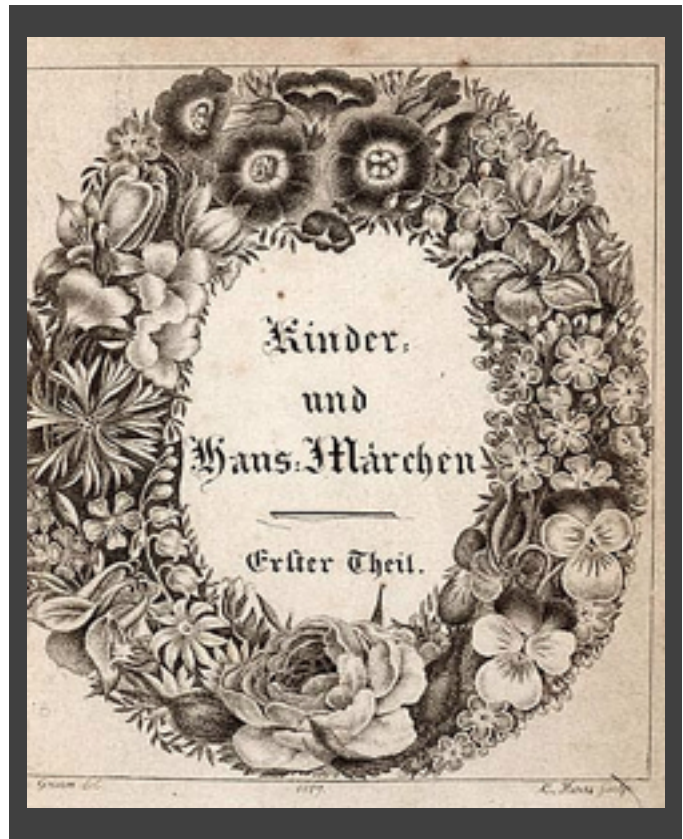

Fonte: Jacob, Wilhelm Grimm (1812).

(1)

Mal Chapeuzinho Vermelho entrou na floresta, o lobo veio a seu encontro. Como Chapeuzinho não sabia que aquele era um animal feroz, não teve medo algum.

- Desejo-lhe um bom-dia, Chapeuzinho Vermelho! - Disse o lobo.

- Muito obrigada, lobo! (GRIMM, OLIVEIRA \& OLIVEIRA, 2009, p. 13-14).

(2)

Lá estava a avó, com a touca cobrindo o rosto, e parecendo muito estranha.

- Credo, vovó, que orelhas tão grandes você tem!

- É para poder ouvir você melhor.

Credo, vovó, que olhos tão grandes você tem!

- É para poder ver você melhor.

- Credo, vovó, que mãos tão grandes você tem!

- É para pode pegar você melhor.

- Mas, vovó, que boca mais assustadoramente grande você tem!

- É para pode comer você melhor. 
Mal disse isso, e o lobo saltou da cama e engoliu a pobre Chapeuzinho Vermelho. E tendo assim saciado seu apetite, tornou a deitar-se na cama, dormiu e começou a roncar muito alto.

Nesse momento, o caçador estava passando bem diante da casa e pensou: "Como ronca a velha senhora: você dever ir ver se ela está precisando de alguma coisa". Entrou na sala e, quando chegou diante da cama, viu o lobo lá deitado.

- Ah, velho malandro - disse ele - aqui te encontro eu, que há tanto tempo ando te procurando!

Já estava armando sua espingarda, mas pensou que talvez o lobo tivesse devorado a avó e ela ainda pudesse ser salva; então, não atirou e, em vez disso, pegou uma tesoura e começou a cortar a barriga do lobo que dormia.

Quando tinha dado algumas tesouradas, viu reluzir o capuz e, depois de mais um para de tesouradas, a menina pulou para fora e gritou:

- Ai, como eu estava assustada, como estava escuro na barriga do lobo! A seguir, saiu a velha avó, também ainda viva, mal podendo respirar. Enquanto isso, Chapeuzinho já fora buscar umas pedras grandes e com elas encheram a barriga do lobo. Quando ele acordou, quis ir ir-se embora, mas as pedras eram tão pesadas que ele logo caiu e morreu. (GRIMM, OLIVEIRA \& OLIVEIRA, 2009, p. 15-16).

Já em Buarque, o fato de a menina não ser devorada pelo lobo, não só vai instaurar outro momento como, ainda, contar uma nova história, outro modo de ser do sujeito mulher que está em questão nas relações entretecidas nesses textos. Sobretudo, pela importância de se discutir a categoria-gênero nos textos que a literatura apresenta. Nesse contexto, a presença do masculino e a herança patriarcal não podem ser ignoradas.

Logo, é a partir desses lugares que se observa que, ao contrário das versões anteriores, Chapeuzinho Amarelo, nessa relação, não será morta e tampouco terá ajuda de um herói para a resolução de seu problema com o lobo. Isso porque, numa subversão de papéis sociais, é ela própria quem vai lidar com a situação, ficando frente a frente com seu opressor (figuras 88 e 89 ) e devolvendo a ele o que o dominante mais teme: o medo (que a imobilizava). Assim, colocando-o no lugar dela por meio da troca de subjetividades é a menina do chapéu amarelo quem vai decidir o seu destino, como se pode observar nos trechos que seguem. 
Figura 88 - $\mathrm{O}$ grande encontro

Figura 89 - A menina e o lobo

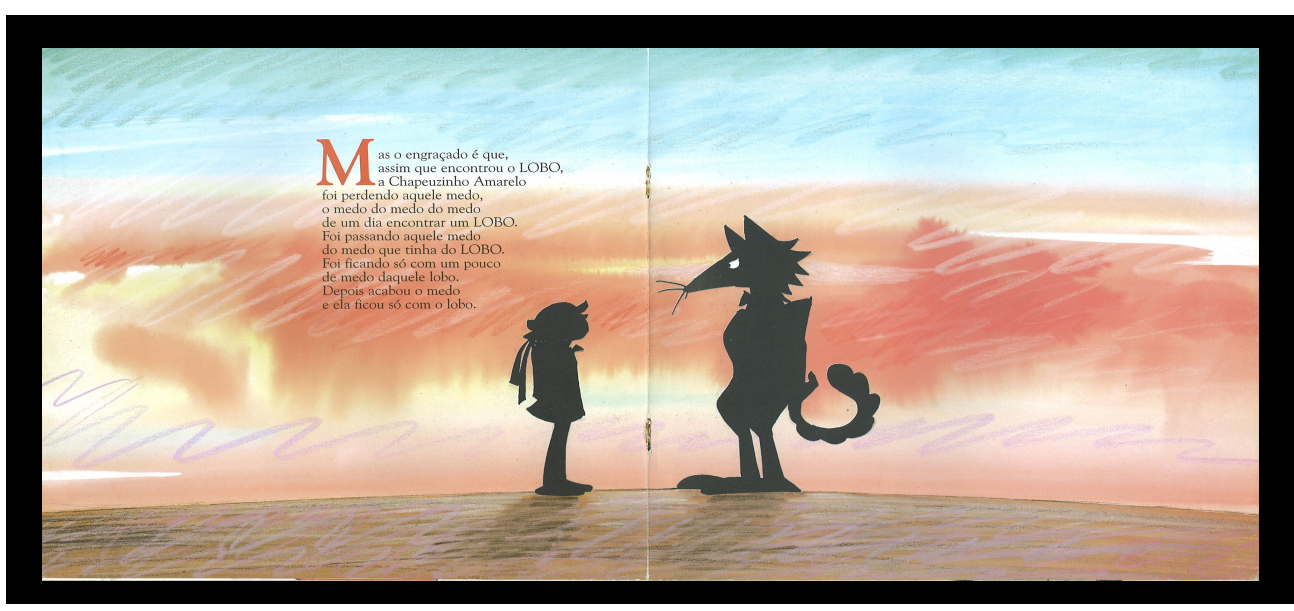

Fonte: Buarque, Ziraldo (2006)

(1)

E Chapeuzinho Amarelo, de tanto pensar no LOBO, de tanto sonhar com o LOBO, de tanto esperar o LOBO, um dia topou com ele que era assim: carão de LOBO, olhão de LOBO, jeitão de LOBO,

e principalmente um bocão tão grande que era capaz de comer duas avós, um caçador, rei, princesa, sete panelas de arroz e um chapéu de sobremesa. (BUARQUE, ZIRALDO, 2006).

Aí,

Chapeuzinho encheu e disse:

"Para assim! Agora! Já!

Do jeito que você tá!"

E o lobo parado assim do jeito que o lobo estava já não era mais um LOBO. Era um BO-LO. 


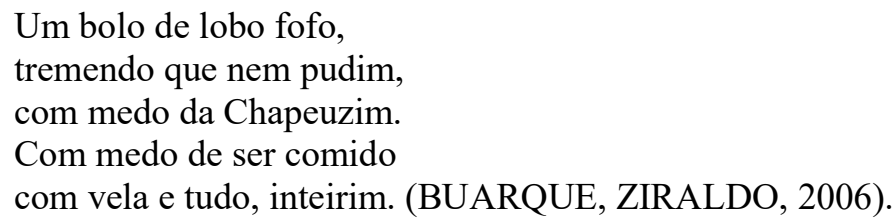

Chapeuzinho não comeu aquele bolo de lobo, porque sempre preferiu de chocolate. (BUARQUE, ZIRALDO, 2006).

Outro ponto relevante em Chapeuzinho Amarelo é que diferentemente das outras duas histórias, ela enfrentar um medo que não está na floresta ou bosque, mas na cabeça dela, reforçado pela simbologia da cor do chapéu amarelo, ou psique; imaginário, fruto, talvez, dos conflitos pelos quais toda menina passa, quando da transição para uma vida adulta. Assim, pode se considerar que o medo, que ela tinha, era gerado por fatores internos, contrariamente ao medo da Chapeuzinho Vermelho, de Perrault e também a dos irmãos Grimm, que estava ligado aos fatores externos, ameaçava a vida fora de casa, ou seja, o perigo do desconhecido.

Como já se disse antes, toda movimentação feita até aqui, é motivada pela leitura da obra de Chico Buarque e Ziraldo que remete ao clássico de Charles Perrault, considerada a primeira versão oficial da publicação de um conto de caráter popular, por meio de mecanismos verbo-visuais como já fora observado em análise passada, e também pela relação de atualização de conteúdo do texto verbal, cuja apresentação passeia pelas temáticas de cunho social e cultural.

Dito isso, pode-se perceber o estreitamento daquela narrativa do passado primordial com essa narrativa do presente contemporâneo, na medida em que o fator da moral, em alta à época dos contos escritos por Perrault, não vigorava como tal, mas como uma espécie de orientação. Agora, recuperada, pelo texto de Buarque e Ziraldo, Chapeuzinho Amarelo, alcança a história da Chapeuzinho Vermelho por meio de referências bem marcadas que vão sendo deixadas no texto como pistas para o leitor.

Por um lado, fazendo a escolha pelo deboche, a dessacralização, a ridicularização, portanto, da figura tão pavorosa do lobo, capaz de engolir tudo que encontrasse pela frente, e por outro porque, ao fazê-lo, autoriza um lugar para a menina, 
antes dominada pelo temor da figura do outro que se desfaz quando ela resolve encará-lo pela primeira vez.

Nessa passagem, tem-se o resultado do encontro ou o final da narrativa, que termina com o lobo, literalmente, com medo da Chapeuzinho Amarelo, experimentando um lugar nunca ocupado antes. E nessa troca de papéis sociais ou identitários, a menina não vai assumir o papel do lobo e fazer com ele o que fora feito com ela no passado. Pois, opostamente àquela figura, não assume o papel do novo colonizador, repetindo o mesmo que ele fez para ter o poder, mas o de alguém que apenas quer ter sua liberdade reconhecida.

Trata-se, em muito, dos aspectos da história da própria mulher. Nesse tocante, o fato de Chapeuzinho Amarelo negar o "bolo de lobo" dizendo que "sempre preferiu de chocolate", confirma um lugar que ela sempre teve, embora até aquele momento não soubesse, além de configurar que ela também sempre soube escolher o que ser, mas nunca tinha tido oportunidade para se manifestar.

Tomando-se, ainda, esses recortes anteriores como "fios de Ariadne" para conduzir o olhar diretamente para as relações que podem ser depreendidas noutros textos, observa-se que, contrariamente, ao que aconteceu com Chapeuzinho Amarelo, Sabrina, a personagem (cujo significado, ironicamente, no étimo anglo-saxônico é: princesa), protagonista da narrativa de Bojunga em Sapato de salto (figura 90), capa com ilustração de Rubem Grilo, não terá o direito de escolha. Ela é presa fácil e frágil para um homem adulto e seus desejos animalescos. A menina, fruto de uma sociedade decadente e conflituosa moralmente, vai ser escravizada, num lar onde deveria receber carinho e afeto, pelas duas figuras que simbolicamente constituem o sentido de família: a do pai e a da mãe.

No entanto, tudo que Sabrina vai conhecer em sua vida de órfã abandonada é o abuso. Além de perder a infância e a inocência, ela perde os sonhos, pois confiava naquele que se tornou seu maior algoz, o seu Gonçalves. Ele representava para ela, a figura de um pai, mas ela é violada por ele (ver em trecho, a seguir). E, aos dez anos, é transformada em prostituta, mesmo destino que tivera a tia dela, assassinada pelo cafetão, e de quem herda, junto com os sapatos de salto (que a tia usava quando ia se prostituir), a triste sina que vai cumprir para sustento não só dela, mas de sua avó doente. Assim, a passagem da infância à vida adulta ou apagamento da infância são representados já capa da obra como se pode 
observar (figura 100) na ilustração de um sapato de salto, bem alto. Sobre o sapato, o Dicionário de Símbolos registra:

Alguns intérpretes fizeram deste símbolo de identificação um símbolo sexual, ou, pelo menos, de desejo sexual despertado pelo é "aqueles que consideram o pé como símbolo fálico verão facilmente no sapato um símbolo vaginal e, entre os dois, um problema de adaptação que pode gerar angústia. (CHEVALIER, 2009, p. 802-803).

A construção de seu Gonçalves como um pedófilo, segue todos os ritos: ganhar a confiança, ser gentil, dar presentes, fazer brincadeiras e, por fim, propor que tudo que acontecesse entre ele e Sabrina ficasse em segredo (tal se assemelha ao primeiro encontro do lobo com Chapeuzinho Vermelho na floresta): "E o grande segredo dos dois passou a animar a vida dele, a botar sombra nos dias dela; e de noite, tudo que é noite, a mesma tensão: ele vem hoje?" (BOJUNGA, 2011, p. 23).

No recorte do romance juvenil de Bojunga, a seguir, é possível ver a relação estreita da passagem em que Sabrina é atacada por seu Gonçalves, tal qual acontece com a Chapeuzinho Vermelho, de acordo com o alerta de Perrault sobre os "lobos melosos" serem os mais perigosos. Ocorre, dessa forma, uma remissão direta àquela narrativa do passado, inclusive por suas marcas intertextuais presentes ao denunciar a ação de seu Gonçalves, que tal qual o lobo, dialoga com a menina antes de devorá-la.

Nesse contexto, considera-se também a ambiguidade deixada na moral, de Perrault, como um elemento importante para essa retomada, uma vez que a figura do lobo é revestida pela metáfora para se falar da ação maldosa do homem. A imagem, descrita por Bojunga, que antecede o momento em que Sabrina é dominada, por seu Gonçalves, em sua cama, remete, de certa forma, à imagem construída pela ilustração de Doré (figura 96) para a Chapeuzinho Vermelho de Perrault, vista anteriormente.

Noutro momento, ainda, em Sapato de salto, como nos contos de fada, vencido os primeiros obstáculos, Sabrina vai morar numa casa toda amarela com sua avó e tia, que passam a cuidar da menina. Aqui, o amarelo se configura como luz ou liberdade, igual ao que acontece com o amarelo da Chapeuzinho Amarelo que, num primeiro momento, representa o medo e depois se transfigura, revelando-se libertação. 
E, assim como nos irmãos Grimm, ela vai contar com a ajuda de um caçador para livrar-se de outros lobos que surgem, e é nesse momento que aparece a figura de uma mulher chamada Paloma (nome de origem espanhola que significa: pomba, e é quem traz a redenção à Sabrina). É ela e não um homem, quem vai salvar a vida da pequena menina, tirando-a da prostituição e dando a ela e à sua avó, um lar de verdade. Nesse contexto, pode se dizer que a história de Sabrina transita entre a oposição semântica que sustenta toda a narrativa, vida $\mathrm{x}$ morte, ao mesmo tempo em que se retroalimenta tanto do diálogo com a história de Perrault quanto com a dos irmãos Grimm.

Figura 90 - Sapato de salto: primeira capa

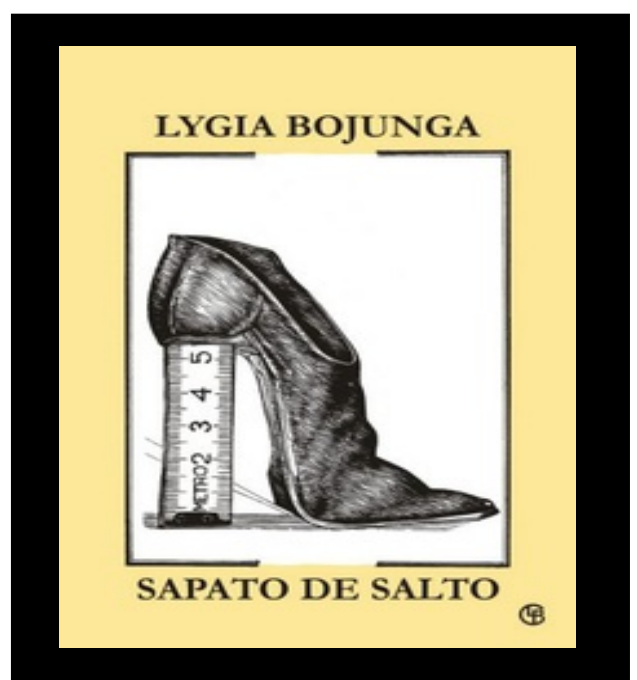

Fonte: Bojunga (2011)

(1)

Um dia trouxe bala pra ela. Ela se espantou:

- Pra mim?

- Presente.

- Presente pra mim?

- Que que tem, ué?

- Primeira vez que eu ganho.

- Ah, é? - E no outro dia trouxe mais.

- Sabrina se encantou. (BOJUNGA, 2011, p. 16).

A curiosidade era grande: Sabrina progredia tanto nos estudos que o seu Gonçalves quis ver se outras aulas iam ser tão bem assimiladas assim. 
Entrou uma noite no quarto dela e se instalou na cama como jeito de quem está inventando uma nova brincadeira. Quando a Sabrina foi gritar de susto, ele tapou o grito com um beijo. E depois cochichou:

- Esse vai ser o nosso maior segredo, viu? - e foi brincando de roçar o bigode na cara dela. Sabrina sentiu o coração disparando. O bigode desceu pro pescoço. Sabrina não resistiu: teve um acesso de riso. De puro nervoso.

- Psiu! psiu! - ele pedia. Mas sem muita preocupação: dona Matilde tinha o sono de pedra, e se a pequena ria daquele jeito é porque estava se divertindo. O bigode foi varrendo cada vez mais forte os cantinhos da Sabrina. Ela sufocava: o nervosismo era tão grande que cada vez ria mais. Ele tirou do caminho lençol, camisola, calcinha.

De dentro da risada saiu uma súplica:

- Que que há, seu Gonçalves? não faz isso pelo amor de deus! O Senhor é que nem meu pai. Pai não faz assim com a gente. - Conseguiu se desprender das mãos dele. Correu pra porta. Ele pulou atrás, arrastou ela de volta pra cama:

- Vem cá com o teu papaizinho.

- Não faz isso! Por favor! Não faz isso! - Tremia, suava. - Não faz isso!

Fez. (BOJUNGA, 2011, p. 22).

Em Antecedentes de uma famosa história (figura 91) depara-se, já na página de apresentação do conto de Alonso, com uma menina, cujo capuz vermelho faz alusão direta à história de Chapeuzinho Vermelho. A figura da menina diante do espelho, revela além de uma dualidade, também uma preocupação com a aparência, o que anuncia tratar-se de uma adolescente ${ }^{28}$ que deseja chamar a atenção e, portanto, preocupa-se com a aparência. Ela, de fato, era bonita (a beleza também é ressaltada em Chapeuzinho Vermelho, de Perrault, logo no início da narrativa) e popular na escola.

Havia um garoto, em particular, que escrevia seus sentimentos por essa menina num caderno. E, para a surpresa do menino (não nomeado), depois do desaparecimento desse objeto (caderno que utilizava como um diário para descrever seus sentimentos em relação à menina), o jovem recebe um bilhete para que se encontre no bosque com a menina de seus sonhos. E eis que é nesse cenário que os sentimentos mais vis são despertados pelas ações também vis da menina que, junto com outros garotos da escola, vão zombar do sentimento do menino apaixonado, cuja vingança anunciada já no título da obra "antecedentes", instiga a percepção para a ocorrência de algo, que sabe-se não terá final

\footnotetext{
${ }^{28} \mathrm{O}$ termo adolescência, nesse contexto, passa a ser considerado como uma concepção, portanto, "produzido histórica e culturalmente e mutável de acordo com a época ou a sociedade que o utiliza.". Ver mais sobre isso em Gregorin Filho, Literatura juvenil, comparativismo e cultura, 2017.
} 
feliz: "Ela me enganou. Eu a amava como um bobo, eu a amava. Sempre a via de longe, cercada de suas amigas; ela era a mais linda." (ALONSO, 2010, p. 57).

A questão, portanto, que interessa nessa relação de diálogos entre as histórias, como anunciado, é o momento final em que o menino humilhado transforma o amor em ódio e se transforma em lobo, seguindo a menina do capuz vermelho que caminhando rumo a casa da avó, vai anunciando aquele final trágico da história de Perrault. Ou seja, por ter brincado com os sentimentos do menino, não retribuindo na mesma medida, ela será punida com a morte.

Do mesmo modo, cabe pensar numa dada subversão de papéis quando a menina, após seduzir a sua presa, o garoto, se diverte com a dor amorosa dele, se comportando com maldade, como se ela fosse o lobo num desdobramento do outro eu. Esse ato, estreita certo diálogo com a ilustração, que se viu, da Chapeuzinho Amarelo (figuras 53 e 54) em que a sombra saindo da própria figura da menina tem o formato do lobo, como se fosse o reflexo do que ela também pode ser ou no que ela pode se transformar. Embora, em Chapeuzinho Amarelo o desfecho não seja o mesmo da narrativa de Alonso, como fica pressuposto no trecho, a seguir.

Figura 91 - Conto: Antecedentes de uma famosa história

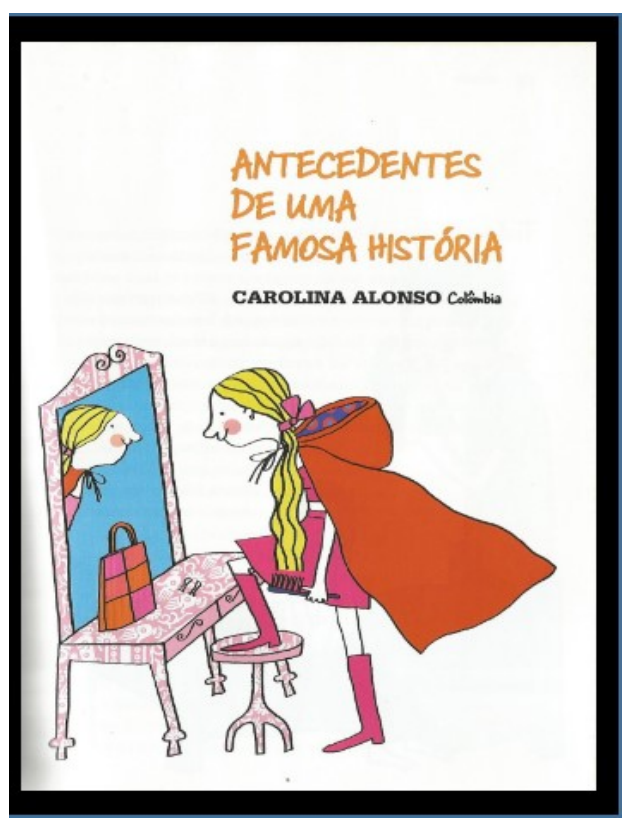

Fonte: Editora Melhoramentos (2010) 
(1)

Então senti seu perfume, e suas mãos cobriram meus olhos. "Olá", disse. E eu quis me virar, descobrir os olhos para vê-la, para comprovar que não se tratava de mais uma de minhas fantasias. Ela não deixou.

[...] o coração exposto. Jogou o papel no chão, abriu-o e tirou as mariposas de papel. "Eu não te amo, idiota", disse-me olhando nos olhos. (ALONSO, 2010, p. 59-61).

Ao amanhecer, havia uma força dentro de mim, algo desconhecido e poderoso que me dominava. Uma criatura que cresce, furiosa e faminta. Já não sou eu, não posso fazer nada. Não posso lutar contra isso; não quero. Não posso me levantar, distingo com nitidez o aroma de tudo o que me cerca, as coisas perderam sua cor. Nada me dói, não sinto frio, uma couraça de pelo duro e negro me protege. Tenho fome, muita fome...

Ouço uma voz, alguém que se aproxima. Esse canto é uma das vozes do coro maligno, quero que se cale. Vejo-a: uma capa vermelha que atravessa o bosque em direção à casa da avó que mora no final do caminho. Não resisto e vou em direção a ela. (ALONSO, 2010, p. 62-63).

Na narrativa em A outra história de Chapeuzinho Vermelho (2016), de JeanClaude R. Alphen (figuras 92, 93 e 94), a seguir, diferentemente das narrativas de Perrault, Grimm e Buarque, observa-se que a permanência desta se dá pelo processo de desconstrução da figura do lobo mau (apagamento da construção do passado) e pela instauração de uma nova relação entre as personagens lobo, menina (simboliza as novas gerações - presente) e avó (essa última como simbologia da representação de gerações antigas - passado). Há, portanto, nessa nova história uma espécie de releitura dos valores culturais do passado em relação aos do presente, ou porque não dizer um ponto de reflexão sobre as figuras homem $\mathrm{x}$ mulher na contemporaneidade.

Assim, a história do lobo que gosta de socializar amizades e gentilezas, que é articulado como um sujeito também dos afazeres domésticos e culinários, como se viu no preparo de panquecas, por exemplo, é mostrado como um ajustamento nas relações possíveis entre os sexos opostos. Questões ainda em conflito na contemporaneidade e que devem começar o quanto antes a serem revistas na sociedade, considerando, nesse contexto, a escola e o período em que "se aprende a ser homem e se aprende a ser mulher", de acordo com as observações de Moreno (1999) sobre o sexismo na escola. 
Aqui, o momento pontual na narrativa se dá com o encontro da menina e do lobo na floresta (figuras 92, 93 e 94), bem como o desdobramento ou fratura que acontece ainda nesse primeiro contato: a presença do livro que traz a clássica versão de Chapeuzinho Vermelho, contada pelos irmãos Grimm e contestada pelo lobo quanto ao final que não é "feliz para todos". O que o motiva a apresentar a sua versão sem conflitos ou diferenças, em que todos seriam amigos e se respeitariam pelas diferenças. E eis que é essa a fratura que anuncia um outro lugar para se ver as mudanças os e valores tão caros à literatura para crianças e jovens dos novos tempos. Nesse sentido, os diálogos, a seguir, são reveladores.

Figura $92-\mathrm{O}$ lobo

Figura $93-\mathrm{O}$ susto

Figura $94-\mathrm{O}$ encontro

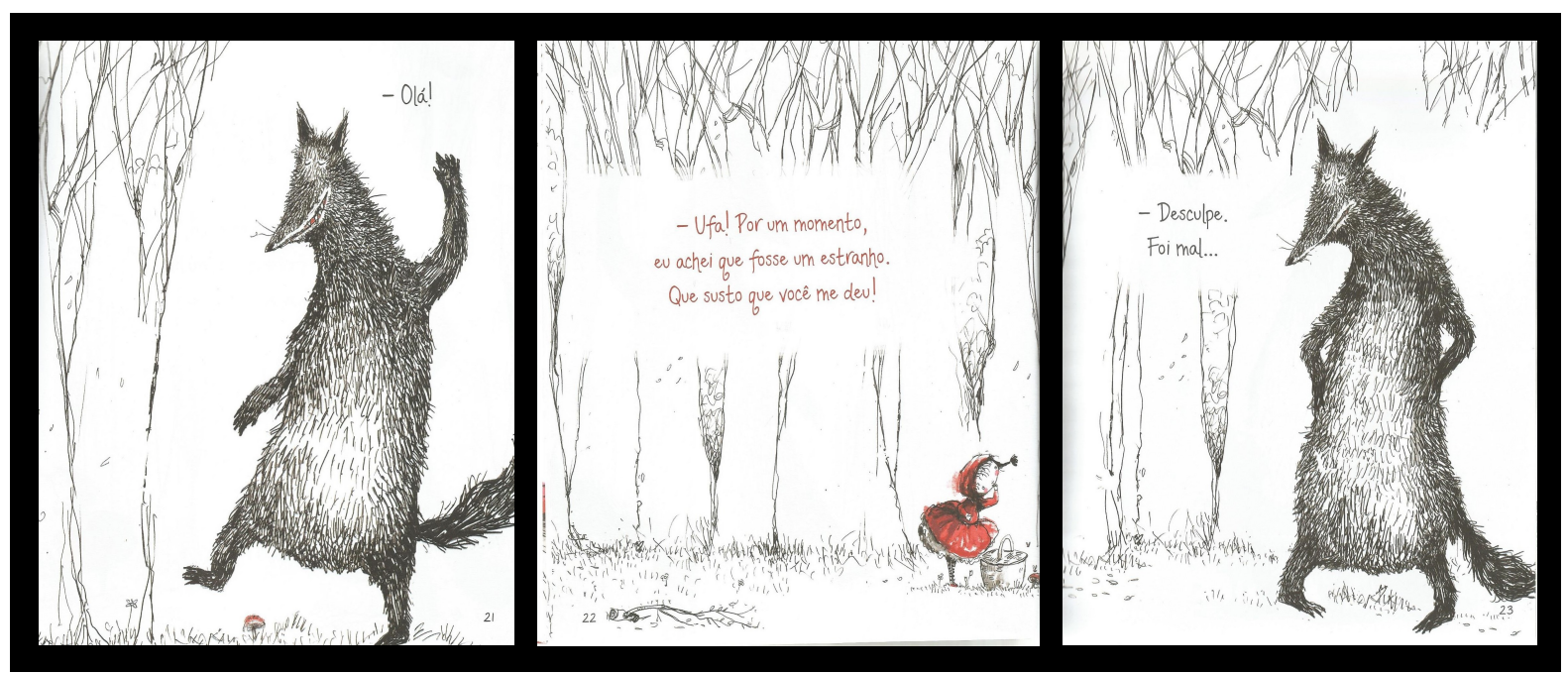

Alphen (2016)

(1)

- Olá!

- Ufa! Por um momento eu achei que fosse um estranho.

- Que susto que você me deu!

- Desculpe.

- Foi mal... (ALPHEN, 2016, p. 21-23).

(2)

Com apenas uma condição!

Só se eu fizer as PANQUECAS! (ALPHEN, 2016, p. 51). 
Igualmente à menina de capuz vermelho da história de Perrault e dos irmãos Grimm, a do chapéu amarelo, de Buarque e Ziraldo, a menina de Alonso e a de Alphen, a garota do conto Preciosidade (1991), de Clarice Lispector, publicado em Laços de família, (figura 95) não é nomeada, gerando um efeito de sentido de falta de autonomia desses sujeitos, como já fora observado em outro momento, ou uma remissão direta ao passado.

Sabe-se que a menina tem 15 anos (um tratamento curioso, dado pela autora à menina, além de chamá-la de preciosa, é o de princesa) e que morre de medo de sair de casa quando o dia está claro. Isso porque teme ser vista por olhos masculinos. Quando saía de casa para a escola, andava sempre se esquivando para que não encontrasse ninguém e, consequentemente, ninguém olhasse para seu corpo (diferente da menina de Alonso, essa teme ser desejada), pois decerto ela tinha consciência que ele havia mudado.

Um ponto que chama a atenção para a observação e que se coloca como central nesse diálogo entre obras, a título de se retomar as figuras do lobo e da menina ou seus desdobramentos: homem e mulher em tempos e sociedades distintas, sobressai nas duas passagens destacadas, a seguir.

Observa-se que essa menina "que tinha 15 anos e não era bonita" está passando pelo processo de mudanças física e psicológicas, não sabe como lidar com isso e, mais, teme perder a inocência que é o que tem de mais precioso. Mas acontece, que assim como as meninas anteriores, ela também vai ser atacada, violada. E tal qual nas outras histórias, o medo é uma constante na vida da menina e o opressor está sempre à espreita, feito sombra, esperando a oportunidade.

Além disso, outros elementos chamam a atenção como, por exemplo, os sapatos de salto de madeira, da menina, que faziam barulho e, logo, chamavam a atenção para a mulher por traz deles. E isso ficava muito pior naquele longo corredor da escola que ela tinha de atravessar todos os dias. Nesse sentido, a simbologia do salto retoma a história da Sabrina, de Bojunga, e lembra que ela passou a usar os sapatos de salto da tia, quando saía para "fazer programa", como uma espécie de rito, confirmação de que já era mulher. Ao final do conto Preciosidade, há também uma confirmação parecida:

Mas no jantar a vida tomou um senso imediato e histérico:

- Preciso de sapatos novos! Os meus fazem muito barulho, uma mulher não pode andar com salto de madeira, chama muita atenção! Ninguém me 
dá nada! Ninguém me dá nada! - e estava tão frenética e estertorada que ninguém teve coragem de lhe dizer que não os ganharia. Só disseram:

- Você não é uma mulher e todo salto é de madeira.

Até que, assim como uma pessoa engorda, ela deixou, sem saber por que processo, de ser preciosa. Há uma obscura lei que faz om que se proteja o ovo até que nasça o pinto, pássaro de fogo.

E ela ganhou os sapatos novos. (LISPECTOR, 1991, p. 116).

O certo é que o que a menina de 15 anos mais temia, vai acontecer. A história da menina do capuz vermelho e do lobo vai se repetir nessa narrativa, assim como se viu em outras. Contudo, em Clarice Lispector, não haverá caçador ou mesmo resolução dos conflitos internos como em Chapeuzinho Amarelo, em que se transformou o "lobo em bolo". Aqui, a garota, assim como Sabrina, não sairá ilesa, após o ataque do qual ela sempre se esquivou pelas ruas (florestas).

Figura 95 - Laços de familia; conto Preciosidade: primeira capa $^{29}$

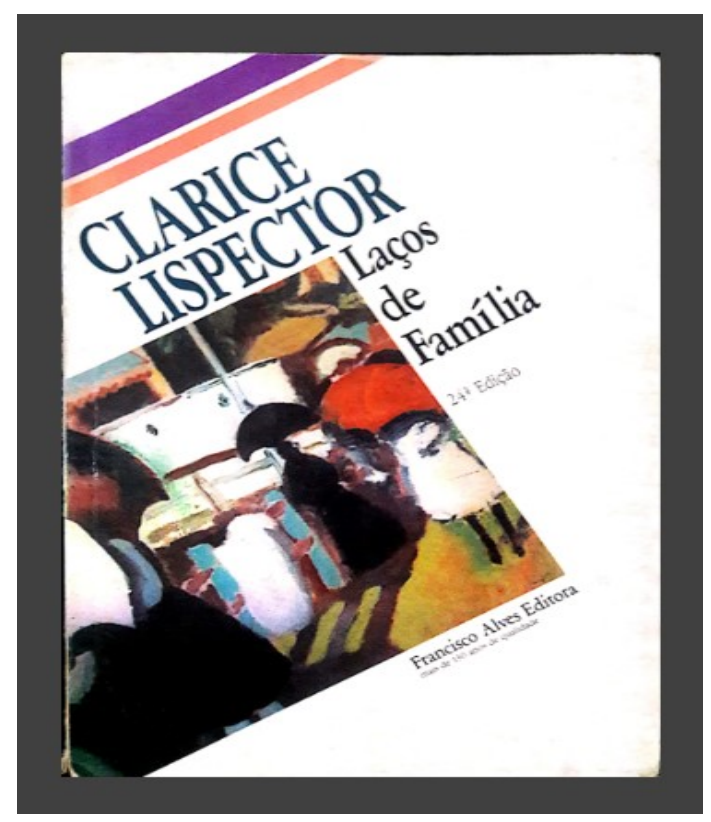

Fonte: Lispector (1991)

\footnotetext{
${ }^{29}$ Capa de Gian Calvi - ilustração: As três sombrinhas, de Raoul Dufy.
} 
(1)

Fazei com eles não digam nada, fazei com que eles só pensem, pensar eu deixo. Ia ser rápido, e um segundo depois da transposição ela diria maravilhada, galgando-se para outras e outras ruas: quase não doeu. (LISPECTOR, 1991, p. 112).

\section{(2)}

O que se seguiu foram quatro mãos difíceis, foram quatro mãos que não sabiam o que queriam, quatro mãos erradas de quem não tinha a vocação, quatro mãos que a tocaram tão inesperadamente que ela fez a coisa mais certa que poderia ter feito no mundo dos movimentos: ficou paralisada. Eles, cujo papel predeterminado era apenas o de passar junto do escuro de seu medo, e então o primeiro dos sete mistérios cairia, eles que representariam apenas o horizonte de um só passo aproximado, eles não compreenderam a função que tinham e, com a individualidade dos que têm medo, haviam atacado. (LISPECTOR, 1991, p. 112).

\subsubsection{Esquema de representação: lobos, meninas e florestas}

O esquema, a seguir, apresenta além das edições atuais das obras que foram utilizadas nas análises e mostradas anteriormente, uma cronologia das suas primeiras publicações (cuja temporalidade é significativa para as contextualizações). Nele é possível observar, como resultado, que mesmo depois das transformações ao longo dos tempos, as instituições, como produtos sociais, findam por cumprir sua função reguladora de regras e costumes excludentes. E, mesmo que novos acordos e contratos tenham sido estabelecidos, as mulheres continuam vulneráveis ao sistema vigente, denunciado nesses textos, dos quais elas são personagens já há muito conhecidas.

Vale ressaltar, que personagens femininas como figuras centrais de narrativas não são novidade na literatura infantil. Basta lembrar das meninas e mulheres que alcançaram a popularidade em histórias do passado e que chegaram até nossos dias com a mesma força de sua existência na memória de vários povos, como foi possível constatar em uma das mais antigas narrativas populares de que se tem notícia, a Chapeuzinho Vermelho, e que abre a célebre coletânea de Contos da Mamãe Gansa, de Charles Perrault. Obra cara a essa à pesquisa na medida em que seu resgaste em novos arranjos reordena novas 
maneiras de se pensar meninos (homens) e meninas (mulheres) e suas relações sociais e culturais na contemporaneidade.

A garota do chapéu vermelho surge novamente nos contos de fada recontados pelos irmãos Grimm e faz parte dos diálogos engendrados pela obra Chapeuzinho Amarelo, de Chico Buarque, ilustrada por Ziraldo. Texto, esse, que atualiza valores, como se viu, a partir das narrativas de outrora, mostrando a figura feminina em sua condição de oprimida, mas capaz de vencer seus conflitos, porque dotada de uma autonomia que regula suas ações, sem a presença do masculino.

Tais obras primordiais, ao serem colocadas no presente sob novas vestimentas, denunciam formas de submissão feminina e exclusão social representadas, ainda, em outras obras analisadas como: Sapato de Salto, de Bojunga, Antecedentes de uma famosa história, de Alonso e Preciosidade, de Clarice Lispector, cuja correspondência trágica com o conto de Perrault se cumpre quando as mulheres desses textos são seduzidas nas florestas metafóricas e simbolicamente devoradas pelos lobos da atualidade.

Outrossim, textos como a Chapeuzinho Vermelho, dos irmãos Grimm, a Chapeuzinho Amarelo, de Chico Buarque e A outra história da Chapeuzinho Vermelho, de Alphen, mantendo uma dada correspondência direta entre elas e resguardando as diferenças temporais com aquela do passado, revelam em suas ressignificações no presente, dadas, sobretudo pela atualização de seus textos, a garantia de um final feliz para suas protagonistas. Isso se se pensa nas mudanças dos paradigmas e na quebra de estereótipos que esses textos propõem, reforçando a necessidade de ajustes na cultura como uma forma de revisão dos valores em respeito às individualidades.

Outra questão, tão marcada nesses textos, é a da sexualidade regida pela relação de opressor x oprimido, o que reafirma que as mulheres em tempos e lugares diferentes da história foram e continuam atingidas pela desigualdade. A separação de natureza e cultura, portanto, se faz fundamental para que se entenda que o que define a diferença de gêneros está centrada na cultura. Nesse tocante, a opressão dentro dos sistemas sociais é mostrada por uma determinada crítica ou denúncia nos textos literários. E manifesta, de acordo com Simões (2009, p. 156) que: "Normas e valores sexuais mudam, mas as restrições que pesam 
sobre a sexualidade das mulheres não são as mesmas que recaem sobre a sexualidade dos homens."

A partir desse cenário narrativo, observado nas análises das obras e organizado no esquema de representação, ao final, conclui-se que dos sete textos apresentados, quatro (Chapeuzinho Vermelho, de Perrault, Preciosidade, de Lispector, Sapato de salto, de Bojunga e Antecedentes de uma famosa história, de Alonso), de modo explícito ou implícito atualizaram a história do lobo mau e da menina do chapéu ou capuz vermelho, de maneira a repetir valores do passado que corroboram a ideia de que os lobos continuam e, portanto, tal manutenção garante a predominância do final trágico em que o lobo devora a menina como uma espécie de apagamento da figura da mulher.

\section{ESQUEMA DE REPRESENTAÇÃO: LOBOS, MENINAS E FLORESTAS}

1. Chapeuzinho Vermelho, de Charles Perrault (1697 - $1^{\text {a }}$ publicação), ilustração de Gustave Doré - Edição utilizada (1996), com tradução de Almeida.

Relações (antes e depois do encontro com o lobo)

HOMEM (Representação do lobo) X MULHER (Representação da Chapeuzinho)

dominante $\quad \mathrm{x}$ dominada

opressor $\quad \mathrm{x}$ oprimida

forte.........................................................fraca

Resultado: nessa narrativa o homem é reafirmado como o sujeito que está no controle de todas as ações, enquanto a mulher, sexo frágil, vivendo conflitos exteriores regulados por padrões sociais e culturais, tem seu reconhecimento, simbolicamente, devorado ou apagado da História. 
2. Chapeuzinho Vermelho, dos irmãos Grimm (1812 - $1^{\mathrm{a}}$ publicação) - Edição utilizada (2009), com tradução de Oliveira.

Relações (antes e depois do encontro com o lobo)

HOMEM (Representação do lobo) X MULHER (Representação da Chapeuzinho)

dominante $\quad \mathrm{x}$ dominada

opressor $\quad \mathrm{x}$ oprimida

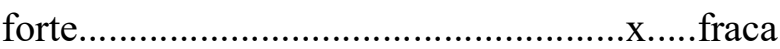

Resultado: na narrativa dos irmãos Grimm ocorre, ainda, a atualização do homem no controle das ações e da mulher como sexo frágil e dependente, que continua vivendo conflitos exteriores regulados por padrões sociais e culturais. Nesse contexto, o medo é reafirmado.

3. Preciosidade, de Clarice Lispector (1960 -1 ${ }^{a}$ publicação) - Edição utilizada (1991).

Relações (antes e depois do encontro com o lobo)

HOMEM (Representação do lobo) x MULHER (Representação da Chapeuzinho)

dominante $\quad \mathrm{x}$ dominada

opressor $\quad \mathrm{x}$ oprimida

forte.........................................................fraca

Resultado: o conto de Lispector é mais uma narrativa que atualiza a situação do homem no controle das ações e da mulher como sexo frágil. Contudo, essa mulher projetada no texto, além dos conflitos exteriores regulados por padrões sociais e culturais, vive conflitos interiores (conflitos existenciais). 
4. Chapeuzinho Amarelo, de Chico Buarque, com ilustração de Ziraldo (1979) - Edição utilizada (2006).

Relações (antes do encontro com o lobo)

HOMEM (Representação do lobo) $\quad$ MULHER (Representação da Chapeuzinho)

dominante $\quad \mathrm{x}$ dominada

opressor $\quad \mathrm{x}$ oprimida

forte.......................................................fraca

Relações (depois do encontro com o lobo)

HOMEM (Representação do lobo) $\quad x \quad$ MULHER (Representação da Chapeuzinho)

dominado

x dominante

oprimido

x opressora

fraco.

.x.....forte

Resultado: nesse texto, num primeiro momento, o homem representa a figura dominante e o controle, por meio do medo, repetindo a história do passado. Todavia, numa subversão de papéis sociais, a mulher em Chapeuzinho Amarelo, representada pelo conflito com a história da mulher que esbarra na luta entre homem e mulher, assume o controle dessa luta, libertando-se do papel de oprimida e firmando-se independente, inclusive porque capaz de não repetir, com o seu algoz, o que sofrera no passado.

5. Sapato de Salto, de Lygia Bojunga (2006 - 1ª publicação) - Edição utilizada (2011).

Relações (antes e depois do encontro com o lobo)

HOMEM (Representação do lobo) $\quad$ X MUHER (Representação da Chapeuzinho)

dominante

x dominada

opressor

X oprimida

forte

..x.....fraca

Resultado: a narrativa de Bojunga permite ver uma dada atualização do homem no controle, ao mesmo tempo em que reforça a mulher como sexo frágil que vive conflitos interiores (conflitos existenciais) e exteriores regulados por padrões sociais e culturais. 
6. Antecedentes de uma famosa história, de Carolina Alonso, com ilustração de Mariana Massarani (2010) - Edição utilizada (2010).

Relações (antes do encontro com o lobo)

HOMEM (Representação da Chapeuzinho) X MULHER (Representação do lobo)

dominado

$\mathrm{x}$ dominante

oprimido

$\mathrm{x}$ opressora

fraco. .x.....forte

Relações (depois do encontro com o lobo)

HOMEM (Representação do lobo) $\quad x \quad$ MULHER (Representação da Chapeuzinho)

dominante

x dominada

opressor

x oprimida

forte .x.....fraca

Resultado: a narrativa de Alonso reforça o papel de fragilidade da mulher, quando subverte os valores de comportamentos estereotipados de homem e mulher, em que o homem é transformado em uma caricatura do feminino não para dar à mulher condições de igualdade, mas para punir o feminino pelo mau comportamento. Dessa forma, o que se tem, ao final, é novamente a atualização do homem no controle e da mulher como sexo frágil, vivendo seus conflitos interiores (conflitos existenciais) e exteriores (conflitos na alteridade) regulados por padrões sociais e culturais.

7. A outra história da Chapeuzinho Vermelho (2016), de Jean-Claude R. Alphen, com ilustração de Jean-Claude R. Alphen (2016) - Edição utilizada (2016).

Relações (antes do encontro com o lobo)

HOMEM (Representação do lobo) $\quad$ X MULHER (Representação da Chapeuzinho)

dominante

$\mathrm{x}$ dominante

forte

.x......forte

Resultado: de maneira bem diferente das outras histórias, na narrativa de Alphen é possível ver uma desconstrução da figura masculina como dominante, bem como em transformação com seus valores sociais e culturais, responsáveis por atualizar, nesse texto, as relações de poder e divisão de controle, conferindo à mulher, portanto, um lugar de igualdade nessa relação que se estabelece. 


\title{
CONSIDERAÇÕES FINAIS: O LOBO COMEU?
}

\begin{abstract}
"São diagramas de linguagens que possibilitam, em reescritas intermináveis, uma interação dialética do presente com o passado, renovando-o. São diagramas que, independente do suporte, encarnam e engendram imagens literárias e metáforas, que nos permitem, em tempos outros, dialogar com angústias, anseios, desejos que ao fim e ao cabo, por serem humanos, permanecem." (CUNHA, 2008, p. 54).
\end{abstract}

A pesquisa permitiu verificar como a literatura infantil, e em menor escala aquela voltada para os jovens da atualidade, passou por transformações nos textos literários para crianças e jovens, a partir sobretudo de mudanças instauradas nas relações sociais, principalmente as questões de gênero. Além disso, foi possível perceber em que medida essa literatura tem manifestado no seu universo textual novas maneiras de percepção sobre as narrativas primordiais ou clássicas consolidadas como tal a partir do século XVII, período importante para o resgate de textos como Chapeuzinho Vermelho, de Charles Perrault e a versão romântica dos irmãos Grimm (dentre outras mencionadas na pesquisa), em consonância com obras do presente e suas atualizações. Assim:

Nesse processo de transformações das relações sociais e do homem e, consequentemente, da literatura infantil, vista pelo viés dos clássicos literários mencionados, recupera-se um discurso que constrói os textos infantis contemporâneos com importante função, qual seja a de perpetuar os valores. Tais transformações ocorridas recuperam um discurso da literatura infantil próprio das manifestações discursivas dadas por ela. (MABELINI, 2007, p. 10).

Ademais, as transformações ocorridas nos novos textos da literatura infantil, sobretudo a partir da segunda metade do século XX, no Brasil, mostrou que tais narrativas e seus valores, outrora marcados pela presença de uma pedagogia altamente moralizante e excludente, agora reorganizam novas estratégias de captação, incluindo a renovação da linguagem nos livros, para retomar não só os clássicos ou histórias que caíram no gosto da criança e do jovem, no passado, mas também para atualizar narrativas capazes de fazer parecer outras, dado o novo arranjo dessas histórias que, assumindo essa nova roupagem, de modo significativo, evidenciam uma literatura com alto grau de esteticidade e 
plasticidade, como se viu na apresentação da obra Chapeuzinho Amarelo, de Chico Buarque, por exemplo.

A literatura infantil e a juvenil, desse modo, vão se firmando cada vez mais como arte, revelando-se pelo modo novo também de mostrar a criança e o jovem num mundo, cujos valores culturais estão em constante mudança. $\mathrm{O}$ que inclui pensar as novas tecnologias e as interações possíveis, capazes de ampliar cada vez mais os textos literários em suportes textuais diversos (o audiovisual, o pictórico, etc.). Ou seja,

[...] hoje não há um ideal absoluto de Literatura Infantil/Juvenil (nem de nenhuma outra espécie literária). Será "ideal" aquela que corresponder a uma certa necessidade do tipo de leitor a que ela se destina, em consonância com a época em que ele está vivendo... Vista em conjunto, a atual produção de Literatura destinada a crianças e jovens, entre nós, apresenta uma crescente diversidade de opções temáticas e estilísticas, sintonizadas com a multiplicidade de visões de mundo que se superpõem no emaranhado da "aldeia global" em que vivemos. (COELHO, 2010, p. 289).

Diante disso, percebeu-se, ainda, que essa nova maneira de ser da literatura infantil e juvenil, capaz de explorar os sentidos e instigar a percepção de mundo da criança e do jovem, mesmo mantendo traços moralizantes se reestruturou no modo como se mostra ou, por assim dizer, atualizou as formas de apresentação dos textos, cujos valores constroem um tipo particular de leitor capaz de dialogar com eles, porque sobretudo se reconhecem nos intertextos e interdiscursos projetados nas leituras.

Cumpre, diante disso, dizer que os textos destinados a esse público, como se viu, têm ampliado sua capacidade sedutora de interação, buscando um diálogo que ultrapassa o tempo e esbarra em questões de ordem variada, mas que sobretudo projetam o sujeito leitor no seu próprio espaço de ação, onde os conflitos e os valores sociais são redimensionados, ganhando status de novidade quando revisitados em narrativas que outrora implicavam outros valores, de certo modo, distantes da criança e do jovem da contemporaneidade.

Nesse tocante, diante da escolha de obras consideradas clássicos da literatura infantil de todos os tempos, como objeto de verificação de atualizações, observou-se seus novos arranjos de apresentação, principalmente quando se trata de textos ilustrados. E pôde-se perceber, com isso, que as relações estabelecidas entre a palavra e a imagem 
aumentaram a qualidade plástica e estética dos textos literários para a criança, principalmente pela relação de justa medida entre as linguagens, isso quando verbal e visual, enfatizando ora uma e ora outra expressão, criam sentidos diferentes entre elas.

As novas relações estabelecidas entre essas linguagens são, como se observou, recursos com os quais o autor do texto trabalha, sendo da ordem de sua competência criar certos efeitos de sentido não só no discurso, mas na própria manifestação textual, pois ela também é portadora de significação. E dessa forma, capaz de inscrever novas perspectivas para os sujeitos leitores, em obras que instigam uma nova percepção, interação e sensibilidade.

A literatura para crianças que ressurge, na segunda metade do século $\mathrm{XX}$, firmando identidade própria, mostra sinais de que sua nova forma de apresentação dos textos faz parecer ser original, por meio de uma nova estética e caráter artístico ou plástico, e tem seu espaço cada vez mais garantido como gênero. Sobre a qualidade plástica, toma-se como exemplo a obra, analisada nesse trabalho, A outra história de Chapeuzinho Vermelho, de Alphen, autor também da ilustração.

Dentre as marcas, percebidas em alguns casos nas narrativas para o público jovem, estão os elementos mágicos, oriundos da tradição popular e dos contos de fada, que de maneira renovada (sem a mágica) asseguram novas intersecções entre textos do passado com os do presente. Isso é bem pontual nas obras Sapato de salto, de Lygia Bojunga, e Preciosidade, de Clarice Lispector, cuja seleção de uma personagem jovem, projeta uma idade que pode ser imaginada pelo leitor. E, assim, tal personagem passa a ser uma representação das aspirações e problemas pessoais do próprio sujeito que entra em contato com essa leitura, bem como as ações que refletem os espaços em que ele pode se reconhecer, num realismo, muitas vezes, construído capaz de trazer à tona questões da própria identidade desse indivíduo.

Isso posto, é importante perceber que, nesse processo de renovação, há uma constante afirmação da própria identidade literária na busca por reconhecimento nos textos, capazes de uma produção cada vez mais eficiente no de diálogo com o presente do leitor. Segundo Coelho:

[...] para além dessa natural diversidade de caminhos impostos pelo "espírito de tempo", há um denominador comum que une as diferentes 
produções: o espírito lúdico (peculiar ao brasileiro) e a busca/afirmação da identidade cultural brasílica (língua, linguagem, diferenças regionais, etc.) (COELHO, 2010, p. 289).

Assim, no bojo dessas mudanças, percebeu-se a partir do "clássico brasileiro," Chapeuzinho Amarelo, de Chico Buarque, apresentada como obra central para as análises propostas, que as possibilidades de diálogos forjados pelo arranjo desse tipo de texto com outros clássicos do passado como Chapeuzinho Vermelho, de Perrault, ou ainda a versão dos Grimm, organizaram intersecções com obras do presente, como ocorreu em Antecedentes de uma famosa história, de Alonso, projetando outras histórias diante da presença da já conhecida menina. Com isso, mostrando também que o momento de conflito na relação do feminino com o masculino mudou e, muito embora os lobos continuem à espreita, a Chapeuzinho nunca mais foi a mesma.

Chapeuzinho Amarelo, como obra da literatura infantil dos novos tempos se consagra como clássico pela atualidade do diálogo que estabelece com o passado do gênero a que pertence, ao mesmo tempo em que dialoga com o processo de criação literária, oscilando entre o repertório conhecido e a inovação, principalmente pela relação estabelecida entre linguagens verbal e visual. E, representa, dessa maneira, a interação entre presente e passado, atualizando questões que sempre estiveram em conflito na vasta floresta de valores e desvalores sociais.

Os processos de atualização de narrativas clássicas mostram que as relações sociais mudaram esse tipo de literatura e o reflexo disso na contemporaneidade, como se viu no decorrer da pesquisa, foram as transformações nos textos literários para crianças e mesmo aqueles voltados para o público jovem; mudanças essas que acarretam novas maneiras de percepção sobre as narrativas de outros tempos em relação ao que se vive no hoje. Evidente que essa pesquisa não esgota o assunto, apenas procura lançar essas reflexões para frente, para os tempos que virão, com novas transformações de narrativas, personagens e, principalmente, de suportes textuais. 


\section{BIBLIOGRAFIA}

ABBAGNANO, Nicola. Dicionário de filosofia. São Paulo: Martins Fontes, 2007. ABRAMOVICH, Fanny. Literatura infantil: gostosuras e bobices. São Paulo: Scipione, 1997.

ALONSO, Carolina. “Antecedentes de uma famosa história”. In: BASCH, Adela et al. Não era uma vez: contos clássicos recontados. Trad. Arnaldo Bonsch; ilustrações Mariana Massarani. São Paulo: Melhoramentos, 2010.

AGRA, Lucio (2004). História da arte do século XX: idéias e movimentos. São Paulo, Editora Anhembi Morumbi.

AGAMBEN, Giorgio. "O que é o contemporâneo?" In $\longrightarrow$ O que é o contemporâneo e outros ensaios. Trad. Vinícius Nicastro Honesko. Chapecó, SC: Argos, 2009.

ALPHEN. Jean-Claude R. A outra história de Chapeuzinho Vermelho. São Paulo: Salamandra, 2016.

ANDERSEN. Hans Christian. Histórias maravilhosas de Andersen. Compilado por Russel Ash e Bernard Higton; trad. Por Heloisa Janh. São Paulo: Companhia das Letrinhas, 1995.

ARNOLD, Arthur. Big bad wolf: Children's literature in education. 1986.

ARIÉS, Philippe. História social da criança e da família. 2. ed. Rio de Janeiro: Editora Guanabara, 1986.

ARROYO, Leonardo. Literatura infantil brasileira. 3. ed. São Paulo: Unesp, 2011.

BARTHES, Roland. Mitologias. Lisboa: Edições 70, 2007.

BASCH, Adela et al. Não era uma vez: contos clássicos recontados. Trad. Arnaldo Bonsch; ilustrações Mariana Massarani. São Paulo: Melhoramentos, 2010.

BAKHTIN, M. Marxismo e Filosofia da Linguagem. São Paulo, Hucitec, 1981.

Marxismo e filosofia da linguagem: problemas fundamentais do método sociológico na ciência da linguagem. São Paulo: Hucitec, 1986.

BELMONTE. In: ENCICLOPÉDIA Itaú Cultural de Arte e Cultura Brasileiras. São Paulo: Itaú Cultural, 2019. Disponível em http://enciclopedia.itaucultural.org.br/pessoas 
10131/belmonte. Acesso em: 20 de ago. 2019. Verbete da Enciclopédia. ISBN: 978-857979-060-7.

BERTRAND, Denis. Caminhos da semiótica literária. São Paulo, Edusc, 2003.

BOJUNGA, Lygia Bojunga. Sapato de salto. Rio de Janeiro: Casa Lygia Bojunga, 2011.

BUARQUE, Chico. Chapeuzinho Amarelo. Ilustr. Ziraldo. 17. ed. Rio de Janeiro: José Olympio, 2006.

BUARQUE, Chico. Chapeuzinho Amarelo. Ilustr. Berlendis. São Paulo: Berlendis \& Vertecchia, 1979.

CALVINO, Ítalo. Por que ler os clássicos. Trad. Nilson Moulin. São Paulo: Companhia das Letras, 2013.

CAMARGO, Luís. A ilustração do livro infantil. Belo Horizonte: Editora Lê, 1995.

CAMPBELL, Joseph. O herói de mil faces. São Paulo: Cultrix/Pensamento, 1995.

CAMPOS, Haroldo de. Pedra e luz na poesia de Dante. Rio de Janeiro: Imago, 1998.

CANDIDO, Antonio. Iniciação à literatura brasileira. 5. ed. Rio de Janeiro: Ouro Sobre Azul, 2006.

Literatura e sociedade. 9. ed. Rio de Janeiro: Ouro Sobre Azul, 2006.

Vários escritos. São Paulo/Rio de Janeiro: Duas Cidades/Ouro Sobre Azul, 2004.

A formação da literatura brasileira. Momentos decisivos. Belo Horizonte, Editora Itatiaia Ltda, 2000.

. "Paixão dos valores". In: Literatura e sociedade. São Paulo: USP/FFLCH/DTLLC, 1996.

CARVALHAL, Tânia e COUTINHO (org.) Literatura comparada. Rio de Janeiro: Rocco, 1994.

CASCUDO, L. da Câmara. Literatura oral no Brasil. Belo Horizonte: Itatiaia, 1984.

CHALHUB, Samira. A metalinguagem. São Paulo: Editora Ática, 1988.

CHEVALIER, Jean. Dicionário de símbolos: (mitos, sonhos, costumes, gestos, formas, figuras, cores, números). Trad. Vera da Costa e Silva... [et al.]. $2^{\mathrm{a}}$ ed. ( $1^{\mathrm{a}}$ reimpressão). Rio de Janeiro: José Olympio, 1990.

COELHO, Nelly Novaes. Panorama histórico da literatura infantil/Juvenil: das origens indo-europeias ao Brasil contemporâneo. São Paulo: Manole, 2010. 
O conto de fadas: símbolos, mitos, arquétipos. São Paulo: DCL, 2003.

A literatura infantil. São Paulo: Moderna, 2000.

Literatura: arte, conhecimento e vida. São Paulo: Peirópolis, 2000.

Literatura infantil: teoria, análise, didática. São Paulo: Moderna, 2000.

Dicionário crítico da literatura infantil brasileira. São Paulo: Edusp, 1995.

O conto de fadas. São Paulo: Ática, 1991.

Literatura e linguagem: a obra literária e a expressão linguística. São Paulo:

Quíron, 1986.

COSTA, Maria Gabriela Cardoso Fernandes da. Sobre as águas da memória atlântica: as vozes entrelaçadas de Lueji - o nascimento dum império e viva o povo brasileiro. Maceió: EDUFAL, 2009.

CUNHA, Maria Antonieta Antunes. Literatura infantil: teoria e prática. São Paulo: Ática, 1983.

CUNHA, Maria Zilda. Entre livros e telas - a narrativa para crianças e jovens: saberes sensíveis e olhares críticos. In: Via Atlântica, n. 14, 2008.

CUNHA, S. R. V. “As transformações da imagem na literatura infantil”. In Pillar, A. D. (org.). A educação do olhar no ensino das artes. Porto Alegre: Mediação, 1999.

DISCINI, Norma. Intertextualidade e conto maravilhoso. Dissertação de mestrado, Universidade de São Paulo, 1995.

DRUMMOND, Carlos. Confissões de Minas. Rio de Janeiro: América Editora, 1944.

ECO, Umberto. Sobre os espelhos. Rio de Janeiro: Nova Fronteira, 1989.

Apocalípticos e integrados. Trad. Pérola de Carvalho. 5. ed. São Paulo, Perspectiva, 1993.

ELIADE, Mircea. Aspectos do mito. Lisboa: Edições 70, 2000.

FIGUEIREDO, Eurídice; NORONHA, M. G. Jovita. In: "Conceitos de literatura e cultura". Juiz de Fora: UFJF, 2005.

FIORIN, José Luiz. Linguagem e ideologia. São Paulo: Ática, 1997.

FREITAS, Marcos Cezar (Org.) História social da infância no Brasil. São Paulo: Cortez, 2006.

FROMM, Erich. A linguagem esquecida: uma introdução ao entendimento dos sonhos, contos de fadas e mitos. Rio de Janeiro: Guanabara-Koogan, 1983. 
GÓES, Lúcia Pimentel. A aventura da literatura para crianças. São Paulo: Melhoramentos, 1991.

GREGORIN FILHO, José Nicolau Literatura juvenil, comparativismo e cultura, Revista Guará, Goiânia, v. 7, n. 1, p. 76-82, 2017.

"Literatura infantil/juvenil e política: um jogo de espelhos". In: ABDALA JUNIOR, Benjamin \& SILVA, Rejane Vecchia Rocha e. Literatura e memória política: Angola. Brasil. Moçambique. Portugal. São Paulo: Ateliê Editorial, 2015.

GREGORIN FILHO, José Nicolau. PINA, Patricia Kátia da Costa; MICHELLI Regina Silva (orgs.). A Literatura infantil e juvenil hoje: múltiplos olhares, diversas leituras. Rio de Janeiro: Dialogarts, 2011.

Literatura infantil: múltiplas linguagens na formação do leitor. São Paulo: Melhoramentos, 2009.

Figurativização e imaginário cultural. Araraquara. SP, 2002. Tese apresentada à FCL-UNESP.

A roupa infantil da literatura. Araraquara, SP: 1995. Dissertação apresentada à FCL-UNESP.

"Literatura infantil/juvenil e política: um jogo de espelhos". In: ABDALA

GREIMAS, A. J. e COURTÉS, J. Dicionário de semiótica. São Paulo: Cultrix, 1979.

Dicionário de semiótica. São Paulo: Cultrix, 1986.

GRIMM. Contos dos irmãos Grimm. Trad. de Ernesto Grégoire e Luiz Mollland. Rio de Janeiro: H. Garnier, 1897.

HEYWOOD, Colin. Uma história da infância: da idade média à época contemporânea no ocidente. Trad. Roberto Cataldo Costa. Porto Alegre: Artmed, 2004.

HOBBES, Thomas. Leviatã ou matéria, forma e poder de um estado eclesiástico e civil. Trad. João Paulo Monteiro e Maria Beatriz Nizza da Silva. São Paulo: Nova Cultural, 1988. JESUALDO, Sosa. A literatura infantil. Tradução de James Amado, São Paulo: Cultrix, 1978.

JOLLES, André. Formas simples: legenda, saga, mito, adivinha, ditado, caso, memorável, conto, chiste. Trad. Álvaro Cabral. São Paulo: Cultrix, 1976.

KOCH, Ingedore G. Villaça; BENTES, Anna Christina; CAVALCANTE, Mônica Magalhães. Intertextualidade: diálogos possíveis. 3. ed. São Paulo: Cortez, 2012. 
LOBATO, Monteiro. A barca de Gleyre. São Paulo: Companhia Editora Nacional, 1944. LAGO, Pedro Corrêa do. Caricaturistas brasileiros: 1836-1999. Rio de Janeiro: Sextante Artes, 1999.

LAJOLO, Marisa e CECCANTINI, João Luís (orgs.) Monteiro Lobato, livro a livro: Obra infantil. São Paulo: Editora da Unesp, Imprensa Oficial do Estado de São Paulo: 2008.

LAJOLO, Marisa. e ZILBERMAN, Regina. Literatura infantil brasileira. São Paulo: Ática, 1984.

LAJOLO Marisa. Usos e abusos da literatura na escola. Rio de Janeiro: Globo, 1982.

LISPECTOR, Clarice. Laços de família. Rio de Janeiro: Francisco Alves, 1991.

MABELINI, Ecila Lira de Lima Mabelini. As estruturas semio-narrativas dos contos de fada e maravilhosos no sincretismo verbo-visual do livro infantil. São Paulo: SP, 2007. Dissertação apresentada à PUC-SP.

A poesia presente. In: Revista Crioula, n. 21, 2018.

MACHADO, Ana Maria. História da Dona Baratinha. São Paulo: FTD, 1996.

MARTINS, Francisco Menezes e SILVA, Juremir Machado da (orgs.). A genealogia do virtual: comunicação, cultura e tecnologias do imaginário. Porto Alegre: Sulinas, 2004.

MARTINS, Maria Helena. Crônica de uma utopia: leitura e literatura infantil em trânsito. São Paulo: Brasiliense, 1989.

MATOS. Maria Izilda S. de. Por uma história da mulher. São Paulo: EDUSC, 2000.

MORENO, Montserrat. Como se ensina a ser menina: o sexismo na escola. Trad. Ana Venite Fuzatto. São Paulo: Moderna, 1999.

MORIN, Edgar. Ciência com consciência. Trad. Maria D. Alexandre e Maria Alice Sampaio Dória. Ed. revista e aumentada pelo autor. 6. ed. Rio de Janeiro: Bertrand Brasil, 2002.

NITRINI, Sandra. Literatura comparada: história, teoria e crítica. 3 ed. São Paulo: Editora EDUSP, 2010.

NODELMAN, Perry. Words about Images: the narrative art of children's picture books. 1988.

OLIVEIRA, Lólio L. de. Chapeuzinho Vermelho: estória e desistória. São Paulo: Aderaldo \& Rothschild, 2009. 
PADILHA, Viriato. Histórias do arco da velha. Biblioteca Infantil da Livraria Quaresma. Livraria Quaresma: Rio de Janeiro, 1959.

PALO, Maria José e OLIVEIRA, M. Rosa. Literatura infantil. São Paulo: Ática, 1986.

PAZ, Noemi. Mitos e ritos de iniciação nos contos de ada. São Paulo: Pensamento, 2005.

PAZ, Otávio. O arco e a lira. Trad. Olga Savary. Rio de Janeiro: Nova Fronteira, 1982.

PEDROSA, Israel. Da cor à cor inexistente. Rio de Janeiro: Léo Christiano Editorial Ltda.

5. ed. Co-editado pela Editora Universidade de Brasília, 1989.

PERROTTI, Edmir. O texto sedutor na literatura infantil. São Paulo: Ícone, 1986.

Confinamento cultural, infância e leitura. São Paulo: Summus Editorial, 1990.

PLATÃO. A Alegoria da caverna: A República, 514a-517c, tradução de Lucy Magalhães. In: MARCONDES, Danilo. "Textos Básicos de Filosofia: dos Pré-socráticos a Wittgenstein". 2 ed. Rio de Janeiro: Jorge Zahar Editor, 2000.

PERRAUlT, Charles. Le contes de Perrault. Ilustração de Gustave Doré. Paris: HetzelStahl, 1862.

. Contos. Trad. Regina Regis Junqueira. Ilustr. Gustave Doré. Belo Horizonte: Itatiaia, 1985.

Chapeuzinho Vermelho. In: “Contos de Perrault”. Tradução de Regina Regis Junqueira. Belo Horizonte: Itatiaia, 1989.

Chapeuzinho Vermelho. In: "Contos de Perrault". Tradução de Fernanda L. de Almeida. São Paulo: Ática, 1996.

Histórias ou contos de outrora. Tradução: Renata Cordeiro. São Paulo: Landy Editora, 2004.

Contos de Charles Perrault. Trad., prefácio e notas: Eliana Bueno Ribeiro. Ilustrações: Gustave Doré. São Paulo: Paulinas, 2016.

PERRONE-MOISÉS, Leyla. Flores da escrivaninha: ensaios. São Paulo: Companhia das Letras, 1990.

PIMENTEL, Figueiredo. Contos da Carochinha. 25. ed. Biblioteca Infantil da Livraria Quaresma. Livraria Quaresma: Rio de Janeiro, 1959. 
Teatrinho infantil: livro para crianças. Biblioteca Infantil da Livraria Quaresma. Nova Edição. Livraria Quaresma: Rio de Janeiro,1959.

Contos da Carochinha. Rio de Janeiro- Belo Horizonte: Quaresma, 1992.

Histórias da Baratinha: Livro para Crianças. Rio de Janeiro: Livraria Garnier, 1994.

PLAZA, Júlio \& TAVARES, Monica. Processos criativos com os meios eletrônicos: poéticas digitais. São Paulo: Hucitec, 1998.

PROENÇA FILHO, Domício. Pós-modernismo e literatura. 2. ed. São Paulo: Ática, 1995.

RESENDE, Vânia. Literatura infantil \& juvenil: vivências de Leitura e Expressão Criadora. São Paulo: Saraiva, 1993.

ROUANET, Sergio Paulo e MAFFESOLI, Michel. Moderno e pós-moderno. Rio de Janeiro: UERJ, 1994.

ROUSSEAU, Jean-Jacques. Émile ou De I'Éducation. 16. Ed. Paris: Classiques Larousse, $\mathrm{s} / \mathrm{d}$.

Emílio ou Da educação. (trad.) FERREIRA, Roberto Leal. 3. ed. São Paulo: Martins Fontes, 2004.

SANTOS, Boaventura de Souza. Pela mão de Alice: o social e o político na pósmodernidade. 14. ed. São Paulo: Cortez, 2013.

SCHWARCZ, Lilia Moritz. "Racismo à brasileira”. In: ALMEIDA, Heloisa Buarque de; SZWAKO, José. (org.). Diferenças, igualdades. São Paulo: Berlendis \& Vertecchia, 2009. SILVA, Vítor Manuel de Aguiar e. Teoria da literatura. Coimbra: Almedina, 2011.

SIMÕES, Júlio Assis. "A sexualidade como questão social e política". In: ALMEIDA, Heloisa Buarque de.; SZWAKO, José. (org.). Diferenças, igualdades. São Paulo: Berlendis \& Vertecchia, 2009.

SOUZA, Ângela Leite de. Contos de fada: Grimm e a literatura oral no Brasil. Belo Horizonte: Editora Lê, 1999.

TODOROV, Tzvetan. A literatura em perigo. Tradução de Caio Meira. Rio de Janeiro: DIFEL, 2009.

Introdução à literatura fantástica. São Paulo: Perspectiva, 1981. 
VALE, Fernando Marques do. A obra infantil de Monteiro Lobato. Inovações e repercussões. Lisboa: Portugalmundo, 1994.

VASCONCELLOS, Zinda Maria Carvalho. O universo ideológico da obra infantil de Monteiro Lobato. São Paulo: Traço Editora, 1982.

WILLIAMS, Raymond. Palavras-chave: um vocabulário de cultura e sociedade. Trad. Sandra Guardini Vanconcelos. São Paulo: Boitempo, 2007.

YUNES, Eliana e PONDÉ, M. da Glória. Leitura e leituras da literatura infantil. São Paulo: FTD, 1988.

ZILBERMAN, Regina. A literatura infantil brasileira. Rio de Janeiro: Objetiva, 2014.

A literatura infantil na escola. São Paulo: Global, 2003.

ZILBERMAN, Regina e LAJOLO, Marisa. A leitura rarefeita: livro e leitura no Brasil. São Paulo: Editora Brasiliense, 1991.

ZILBERMAN, Regina (org.). Leitura em crise na escola. Porto Alegre: Mercado Aberto, 1982.

(org.). A produção cultural para crianças. Porto Alegre: Mercado Aberto, 1982.

ZIRALDO. Flicts. São Paulo: Melhoramentos, 2006. 
ANEXO A - Shrek (2001)

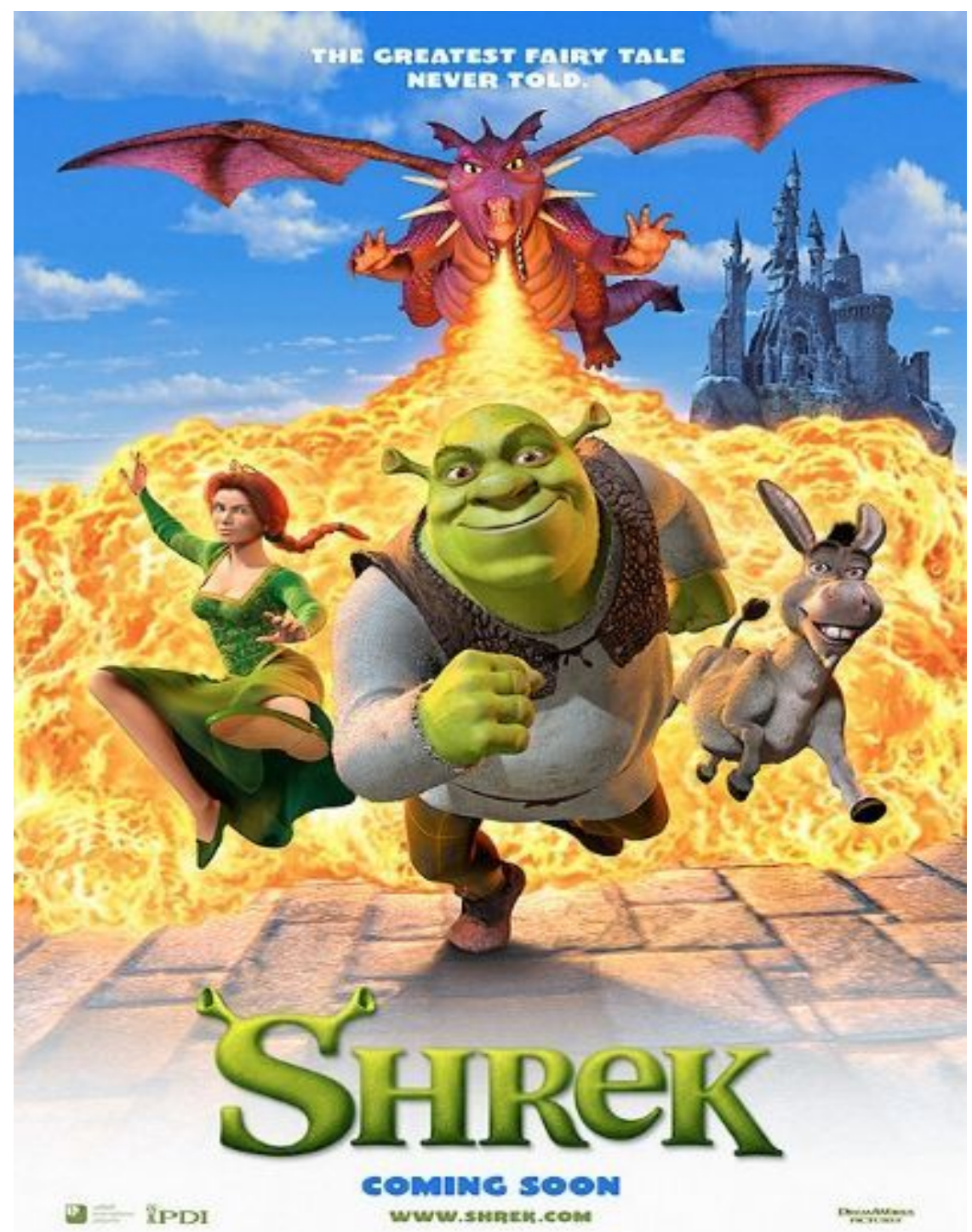


ANEXO B - Capa do livro Emília no país da gramática, de Monteiro Lobato

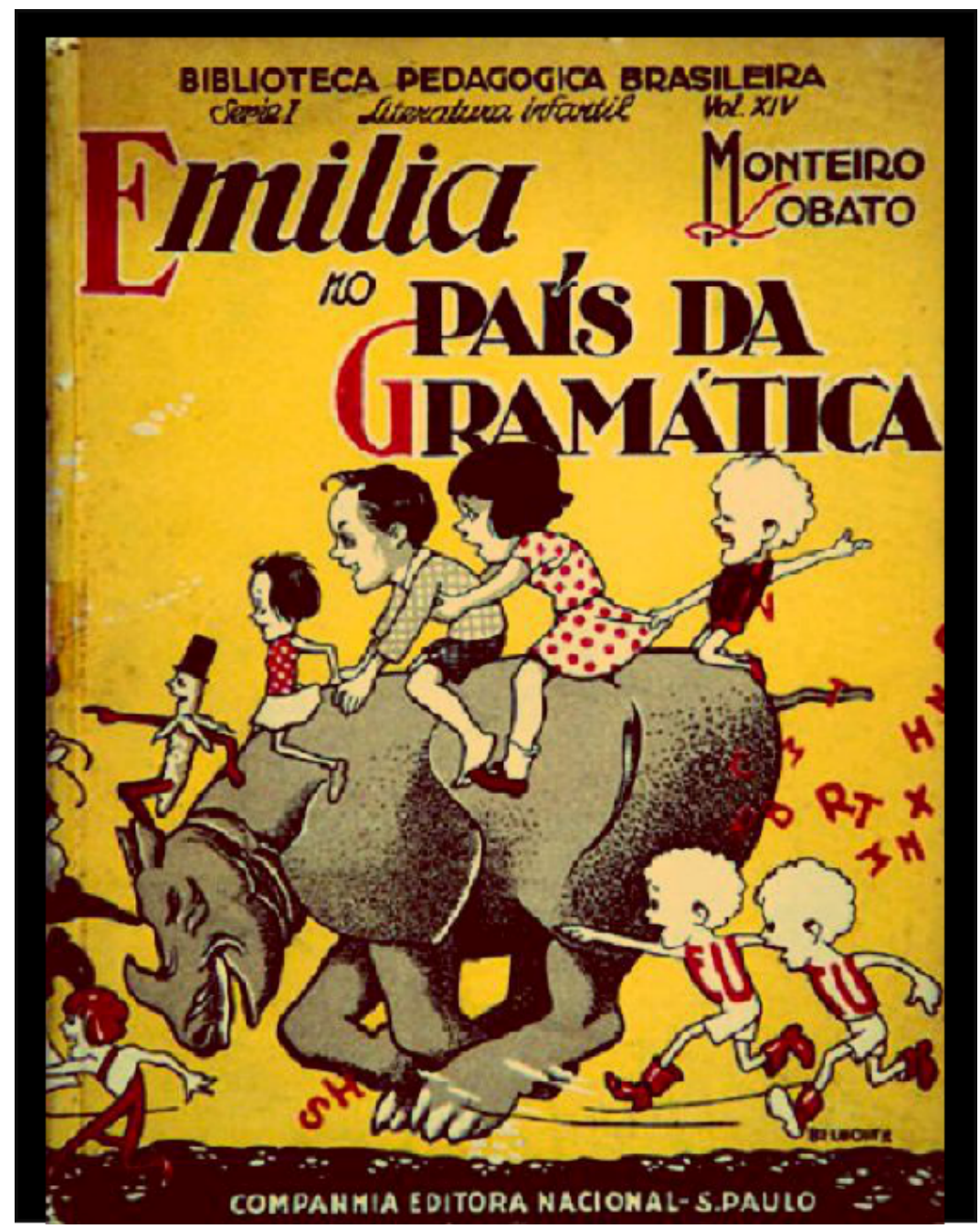


ANEXO C - Chapeuzinho Vermelho, de Charles Perrault (tradução de Fernanda L. de Almeida).

ERA UMA VEZ UMA PEQUENA CAMPONESA, a mais bonita que se possa imaginar. Sua mãe era louca por ela e sua avó mais ainda.

A avó fez-lhe um pequeno chapéu vermelho que lhe assentava maravilhosamente bem. Por isso, em toda parte, passaram a chama-la Chapeuzinho Vermelho.

Um dia, tendo feito bolos folhados, a mãe chamou Chapeuzinho Vermelho e disse:

- Vai ver como anda tua avó. Disseram-me que está doente. Aproveita e leva-lhe um destes bolos e este pequeno pote de manteiga fresca.

Chapeuzinho Vermelho partiu para a casa da avó, que morava em outra aldeia.

Passando dentro de um bosque, encontrou o Compadre Lobo, que teve logo vontade de comê-la.

Mas não ousou fazer isso, por causa de uns lenhadores que estavam na floresta.

- Para onde você está indo? - perguntou então.

A pobre criança, que não sabia como é perigoso parar para escutar lobos, respondeu:

- Vou visitar minha avó e levar-lhe um bolo e um pequeno pote de manteiga.

- Ela mora muito longe?

- Ah, mora - disse Chapeuzinho Vermelho. - É lá, depois do moinho, está vendo? Na primeira casa da aldeia.

- Muito bem - disse o lobo - quero ir visitá-la também. Eu vou por este caminho aqui e você por aquele caminho lá. Vamos apostar quem chega primeiro?

E, sem esperar resposta, começou a correr a toda velocidade, pelo caminho mais curto.

A menina foi pelo caminho mais longo. Divertiu-se colhendo avelãs, correndo atrás das borboletas e fazendo buquês com as florezinhas que encontrava. De modo que demorou bastante. 
O lobo não levou muito tempo para chegar à casa da avó. Bateu: toc, toc, toc.

- Quem está aí? - perguntaram lá de dentro.

- É sua neta, Chapeuzinho Vermelho - respondeu o lobo, afinando a voz. Estou trazendo um bolo e um potezinho de manteiga fresca, que minha mãe lhe mandou.

A boa avozinha estava de cama, porque não se sentia bem. Para não levantar, explicou:

- Levanta o ferrolho e empurra a porta, minha filha.

O lobo fez como ela dizia e a porta abriu-se. Ele se jogou sobre a boa mulher e a devorou num piscar de olhos, pois havia três dias que não comia.

Em seguida, fechou a porta e foi deitar-se na cama. Ficou esperando.

Pouco depois, Chapeuzinho Vermelho bateu: toc, toc, toc.

- Quem está aí?

Ouvindo aquela voz tão grossa, Chapeuzinho Vermelho no princípio teve medo. Mas depois, acreditando que sua avó estivesse resfriada, respondeu:

- É sua neta, Chapeuzinho Vermelho. Estou trazendo um bolo e um pequeno pote de manteiga, que minha mãe lhe mandou.

O lobo adoçou um pouco a voz e gritou:

- Levanta o ferrolho e empurra a porta, minha filha.

Chapeuzinho Vermelho levantou o ferrolho e a porta abriu-se.

O lobo escondeu-se debaixo das cobertas e disse:

- Põe o bolo e o potezinho de manteiga sobre a arca e vem deitar-te ao meu lado.

Chapeuzinho Vermelho fez isso.

Ficou muito espantada vendo como sua avó estava diferente. Disse:

- Vovó, que braços grandes a senhora tem!

- É para te abraçar, minha neta.

- Vovó, que pernas grandes a senhora tem!

- É para melhor correr, minha filha.

- Vovó, que orelhas grandes a senhora tem!

- É para escutar, minha criança.

- Vovó, que olhos grandes a senhora tem!

- É para melhor te enxergar, minha querida. 
- Vovó, que dentes grandes a senhora tem!

- É para te comer.

E, dizendo essas palavras, o malvado lobo jogou-se sobre Chapeuzinho Vermelho e comeu-a.

Toda menina deve ser capaz

De dizer "sim" ou "não" conforme queira,

Tanto a um lobo sem eira nem beira

Quanto a um belo rapaz.

Hoje em dia, as meninas avisadas

Sabem reconhecer o lobo vil

E não iriam pelos próprios pés

Cair em seu ardil.

Há pessoas bem mais indicadas

Pra conversar no meio do caminho

Do que um lobo mal-intencionado

E sem nenhum carinho. 
ANEXO D - Chapeuzinho Vermelho, dos irmãos Grimm (tradução de Ilse K. L. de Oliveira e Lólio L. de Oliveira

ERA UMA VEZ UMA GAROTINHA muito meiga de quem todos gostavam, assim que a conheciam. Mas quem mais gostavam dela era mesmo a sua avó que não sabia mais que fazer por ela. Certa vez deu-lhe de presente um capuz de veludo vermelho que lhe ficou tão bem, que ela nunc mais deixou de usar, e por isso passou a ser chamada de Chapeuzinho Vermelho.

Um dia sua mãe disse:

- Venha cá, Chapeuzinho Vermelho. Aqui está um pedaço de bolo e uma garrafa de vinho para levar para a vovó: ela está muito doente e fraca e vai deliciar-se com isso. Primeiro, vá se vestir, antes fique muito calor; depois, quando sair, tenha juízo e não se afaste do caminho, senão vai cai, quebra a garrafa e a vovó fica nada. E quando entrar na cada dela, não se esqueça: primeiro, diga-lhe bom-dia, e não comece logo a xeretar por tudo canto.

- Vou fazer tudo direitinho - disse Chapeuzinho Vermelho a sua mãe. Depois, deu-lhe a mão para se despedir.

A avó morava lá no meio da floresta, a uma meia hora da aldeia. Mal Chapeuzinho Vermelho entrou na floresta, o lobo veio a seu encontro. Como Chapeuzinho Vermelho não sabia que aquele era um animal feroz, não teve medo algum.

- Desejo-lhe um bom-dia, Chapeuzinho Vermelho! - disse o lobo.

- Muito obrigada, lobo!

- Aonde vai tão cedo, Chapeuzinho Vermelho?

- À casa da vovó.

- O que está levando nessa cesta?

- Um bolo que nós assamos ontem e uma garrafa de vinho.

Assim a vovó, que está doente e fraca, terá uma coisa gostosa para comer, e com isso se fortificará.

- Chapeuzinho Vermelho, onde mora a sua avó? 
A casa dela é mais para dentro da floresta, a um quarto de hora daqui, sob três grandes carvalhos. Mais para baixo, está aquela fileira de nogueiras, como você já deve saber - disse Chapeuzinho Vermelho.

O lobo pensou consigo mesmo: "Esta coisinha nova e tenra, isto sim é um bom bocado; vai ser mias gostosa do que a velha! Você precisa andar depressa, para poder pegar as duas". Andou durante algum tempo do lado de Chapeuzinho Vermelho e depois falou:

- Chapeuzinho Vermelho, veja só que lindas flores à nossa volta, por que você não dá uma olhada? Acho que você nem tá ouvindo como os pássaros cantam tão bonito. Você anda tão direitinho, como se estivesse indo para a escola e, no entanto, aqui na floresta é tão divertido.

Chapeuzinho Vermelho abriu bem os olhos e, ao ver como os raios de sol dançavam de um lado para o outro, por entre os galhos das árvores, e como estava tudo tão cheio de flores tão belas pensou: "Se eu levasse um ramalhete de flores frescas para a vovó, não me atrasaria com isso". E deixou o caminho, entrando pela floresta para colher flores. A cada uma que apanhava, pensava que mais adiante havia outra mais bonita, e ia procurar, e assim foi entrando cada vez mais profundamente na floresta.

O lobo, porém, foi diretamente para a casa da avó e bateu na porta.

- Quem está aí?

- É Chapeuzinho Vermelho, trazendo bolo e vinho. Abra a porta.

- É só girar a tramela - disse a avó. - Estou muito fraca e não posso levantar.

O lobo girou a tramela, a porta se abriu e, sem dizer palavra, foi direto para a cama a avó e a devorou. Depois, vestiu as roupas dela, pôs a touca que usava, deitou-se na cama e cerrou o cortinado.

Enquanto isso, Chapeuzinho Vermelho continuava correndo atrás das flores e, quando já juntara tantas flores que nem podia carregar, tornou-se a lembrar-se da avó e tomou de novo o caminho de sua casa. Espantou-se ao ver que a porta estava aberta e, ao entrar na sala, achou tudo tão estranho, que pensou: "Ai, meu Deus, que medo estou sentindo, e no entanto gosto tanto de estar na casa da vovó".

-Bom dia - ela disse, mas não recebeu resposta. Dirigiu-se, então, para a cama e abriu o cortinado. Lá estava a avó, com a touca cobrindo o rosto, e parecendo muito estranha. 
- Credo, vovó, que orelhas tão grandes você tem!

- É para poder ouvir você melhor.

- Credo, vovó, que olhos tão grandes você tem!

- É para poder ver você melhor.

- Credo, vovó, que mãos tão grandes você tem!

- É para poder pegar você melhor.

- Mas vovó, que boca mais assustadoramente grande você tem!

- É para poder comer você melhor.

Mal disse isso, o lobo saltou da cama e engoliu a pobre Chapeuzinho Vermelho. E tendo assim saciado seu apetite, tornou a deitar-se na cama, dormiu e começou a roncar muito alto.

Nesse momento, o caçador estava passando bem diante da casa e pensou: "Como ronca a velha senhora: você deve ir ver se ela está precisando de alguma coisa". Entrou na sala e, quando chegou diante da cama, viu o lobo lá deitado.

Ah! Velho malandro - disse ele - aqui te encontro eu, que há tanto tempo ando te procurando!

Já estava armando sua espingarda, mas pensou que talvez o lobo tivesse devorado a avó e ela ainda pudesse ser salva; então, não atirou e, em vez disso, pegou uma tesoura e começou a cortar a barriga do lobo que dormia.

Quando tinha dado algumas tesouradas, viu reluzir o capuz e, depois de mais um par de tesouradas, a menina pulou para fora e gritou:

- Ai, como eu estava assustada, como estava escuro na barriga do lobo!

A seguir saiu a velha avó, também ainda viva, mal podendo respirar. Enquanto isso, Chapeuzinho Vermelho já fora buscar umas pedras grandes e com elas encheram a barriga do lobo. Quando ele acordou, quis ir-se embora, mas as pedras eram tão pesadas que ele logo caiu e morreu.

Então, os três ficaram contentes. O caçador tirou a pele do lobo e foi com ela para casa; a avó comeu o bolo e bebeu o vinho que Chapeuzinho Vermelho trouxera e tomou a ficar boa; e Chapeuzinho Vermelho pensou: "Você nunca mais na sua vida vai abandonar o caminho e entrar sozinha pela floresta, quando sua mãe tiver proibido de fazer. 
Conta-se, também, que uma outra vez que Chapeuzinho Vermelho foi levar bolos à casa de sua avó, um outro lobo veio falar com ela, tentando desviá-la do caminho. Mas Chapeuzinho Vermelho precaveu-se e continuou direitinho pela estrada. Contou para a avó que o lobo tinha vindo a seu encontro e lhe desejara um bom-dia, e que a tinha com um olhar tão feio que "se não estivéssemos em campo aberto, ele me teria devorado".

- Vem - disse a avó - vamos trancar a porta para ele não poder entrar.

Logo depois, o lobo bateu e disse:

- Abra, vovó, sou eu, Chapeuzinho Vermelho, estou lhe trazendo bolos.

Elas ficaram bem quietas e não abriram a porta. Então, o lobo deu várias voltas na casa e, afinal, subiu para o telhado, com a intenção de esperar até que Chapeuzinho Vermelho fosse para casa à noite, quando então a seguiria e a devoraria no meio da escuridão. A avó, porém, percebeu qual era sua ideia.

$\mathrm{Na}$ frente da casa havia uma grande tina de pedra, e a avó disse à menina:

- Ontem cozinhei linguiça, Chapeuzinho Vermelho; pegue o balde e traga toda a água onde elas ferveram e despeje na tina.

Chapeuzinho Vermelho levou muito tempo carregando a água, até que a tina ficou completamente cheia.

Então, o cheiro da linguiça chegou ao nariz do lobo e ele começou a farejar e olhar par baixo, até que se esticou tanto o pescoço que não conseguiu mais se segurar, começou a escorregar e a acabou despencando do telhado bem dentro da tina, e ali se afogou.

Chapeuzinho Vermelho foi feliz para casa e ninguém lhe fez nada. 